INSTITUTO DE PESQUISAS ENERGÉTICAS E NUCLEARES

Autarquia associada à Universidade de São Paulo

PROPOSTA DE NOVAS CONFIGURAÇÕES PARA O NÚCLEO DO REATOR IEA-R1 DO IPEN/CNEN-SP COM COMBUSTÍVEIS DE ALTA DENSIDADE DE URÂNIO

Thiago Garcia João

Tese apresentada como parte dos requisitos para obtenção do Grau de Doutor em Ciências na Área de Tecnologia Nuclear - Reatores

Orientador:

Prof. Dr. Antonio Teixeira e Silva

Versão Corrigida

Versão Original disponível no IPEN

São Paulo

2016 
"A todos que, direta ou indiretamente, contribuíram para a realização deste trabalho, em especial a meus pais, Sílvia e Cláudio." 


\section{Agradecimentos}

A meus pais, Sílvia e Cláudio, por terem me proporcionado as condições necessárias para estudar e fazer as coisas que gosto.

À Fundação de Amparo à Pesquisa do Estado de São Paulo - FAPESP, pelo apoio financeiro, sob o projeto $\mathrm{n}^{\circ}: 2011 / 17090-7$.

Ao Dr. Antonio Teixeira e Silva, pela orientação ao longo da execução deste trabalho, pelos conselhos e dedicação.

Ao Dr. Arthur E. Ruggles e ao Dr. Ivan Maldonado, ambos Pesquisadores e Professores da Universidade do Tennessee - EUA, onde realizei parte de meus estudos e pesquisa de doutorado.

Ao Instituto de Pesquisas Energéticas e Nucleares, IPEN/CNEN-SP, pela estrutura e pelo fornecimento dos meios necessários para o desenvolvimento deste estudo.

Aos amigos que fiz na pós-graduação, em especial ao Dr. Pedro Carlos Russo Rossi, Dr. Douglas Borges Domingos, Dr. Rafael Oliveira Rondon Muniz, Dr. Gabriel Ângelo, Dr. Luís Felipe Liambos Mura e Dr. Rodrigo Salemi Viana.

A meu primo Guilherme Antunes Rodrigues e a minha tia Maria da Graça João Rodrigues, pela hospitalidade e por me receber em suas residências inúmeras vezes. 
"I think it's much more interesting to live not knowing than to have answers which might be wrong. I have approximate answers and possible beliefs and different degrees of uncertainty about different things, but I am not absolutely sure of anything and there are many things I don't know anything about, such as whether it means anything to ask why we're here. I don't have to know an answer. I don't feel frightened not knowing things, by being lost in a mysterious universe without any purpose, which is the way it really is as far as I can tell." 


\title{
PROPOSTA DE NOVAS CONFIGURAÇÕES PARA O NÚCLEO DO REATOR IEA-R1 DO IPEN/CNEN-SP COM COMBUSTÍVEIS DE ALTA DENSIDADE DE URÂNIO
}

\author{
THIAGO GARCIA JOÃO
}

\begin{abstract}
Resumo
O presente estudo foi realizado para verificar a possibilidade de redução do núcleo do reator IEA-R1 do IPEN/CNEN-SP. Cálculos neutrônicos foram desenvolvidos para um conjunto de novas configurações para que, a posteriori, a análise termo-hidráulica e de segurança pudessem ser realizadas.

As novas configurações analisadas são menores por diversos motivos, como obter uma melhor utilização do combustível, melhor distribuição dos fluxos de nêutrons, dentre outros. Para que se possa atingir tais configurações, a densidade de Urânio no combustível deve ser aumentada. Neste estudo, combustíveis de $\mathrm{U}_{3} \mathrm{Si}_{2}-\mathrm{Al}$ com $4,8 \mathrm{gU} / \mathrm{cm}^{3}$ foram testados e novos núcleos para o reator IEA-R1 foram propostos e discutidos.

A análise neutrônica não impõe restrições aos núcleos estudados. A análise termohidráulica mostrou que as margens de segurança e os perfis de temperatura ao longo das placas combustíveis não excedem os limites de projeto. Os coeficientes de temperatura obtidos para os novos núcleos, no caso isotérmico, são todos negativos, conforme desejado. A queima mostrou que núcleos supercompactos não apresentam excesso de reatividade suficiente para o funcionamento dos mesmo, ao se utilizar combustíveis $\operatorname{com} 4,8 \mathrm{gU} / \mathrm{cm}^{3}$.

Um APR (Acidente de Perda de Refrigerante) foi simulado para os núcleos remanescentes. A ruptura da fronteira do primário se mostrou o acidente mais crítico, devido ao curto tempo para o esvaziamento completo da piscina do reator. As temperaturas atingidas após o descobrimento foram calculadas e não excedem aquelas cujos valores propiciam empolamento nas placas combustíveis $\left(475^{\circ} \mathrm{C}\right.$ a $\left.550{ }^{\circ} \mathrm{C}\right)$, uma vez que se obedeça os tempos de esvaziamento seguro da piscina para as novas configurações.
\end{abstract}




\title{
PROPOSAL OF NEW CORE CONFIGURATIONS FOR THE IPEN/CNEN-SP IEA-R1 RESEARCH REACTOR WITH HIGH DENSITY URANIUM FUELS
}

\author{
THIAGO GARCIA JOÃO
}

\begin{abstract}
This study was performed considering prospective candidates for the IPEN/CNEN-SP IEA-R1 research reactor core. Some neutronic calculations were developed for a set of new core configurations to push forward the thermal-hydraulic and safety analysis.

The new core configurations will be smaller for several reasons (e.g., better fuel utilization, neutron fluxes and so on). To achieve such smaller arrangements, the U-fuel density has to be increased. In the current study, configurations with $4.8 \mathrm{gU} / \mathrm{cm}^{3} \mathrm{U}_{3} \mathrm{Si}_{2}-$ $\mathrm{Al}$ fuels were tested using the software MCNP and a set of new core configurations for the IPEN/CNEN-SP IEA-R1 research reactor has been presented and discussed.

The Neutronic analysis imposes no restrictions on the new cores. The ThermalHydraulic $(\mathrm{TH})$ analysis showed that the safety margins and the temperature profile through the fuel plate don't exceed the design limits. The isothermal temperature coefficients were calculated being all negative, as desired. The burnup concludes that super compact cores don't have enough excess reactivity to keep the reactor working with $4.8 \mathrm{gU} / \mathrm{cm}^{3} \mathrm{U}_{3} \mathrm{Si}_{2}-\mathrm{Al}$ fuels.

A LOCA (Loss of Cooling Accident) was simulated for the remaining cores. The border rupture of the primary system was the most critical accident, due to the short time for the complete emptying of the reactor pool. The temperatures reached after this accident were calculated and don't exceed the fuel plates limits $\left(475^{\circ} \mathrm{C}-550^{\circ} \mathrm{C}\right)$, once the time for safe emptying are taken into account for the IEA-R1 pool.
\end{abstract}




\section{Lista de Figuras}

Figura 1- Visão superior do núcleo atual, 5x5 do reator IEA-R1 (MCNP).................... 12

Figura 2 - História aleatória de um nêutron incidente num slab de material físsil..........20

Figura 3 - Esquema simplificado do modelo MTRCR-IEAR1 .....................................22

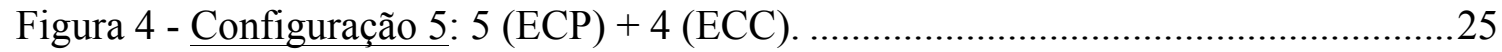

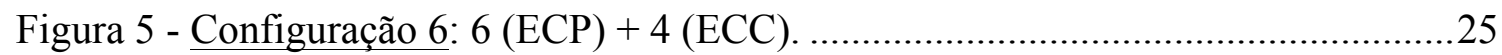

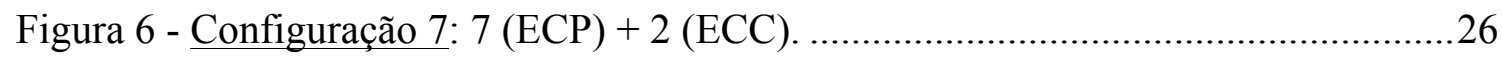

Figura 7 - Configuração 8: 8 (ECP) + 4 (ECC). ….................................................... 26

Figura 8 - Configuração $8^{*}: 8($ ECP) +4 (ECC).......................................................26

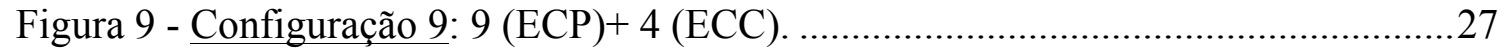

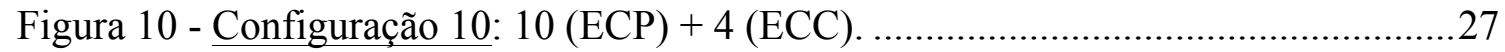

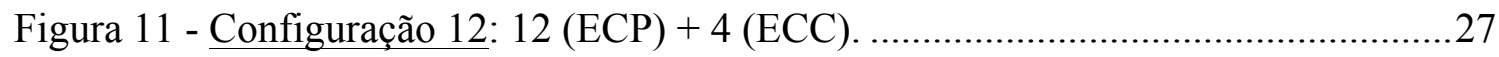

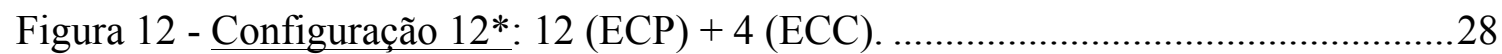

Figura 13 - Representação esquemática de uma reação em cadeia auto-sustentada e baseada na fissão de núcleos de urânio por nêutrons térmicos. ....................................29

Figura 14 - Relação entre a margem de desligamento, valor total dos elementos de

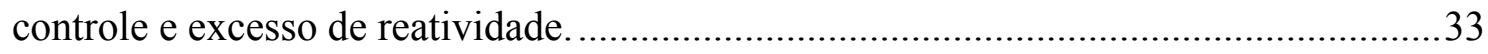

Figura 15 - Fator de pico local vs. Comprimento normalizado (placa mais quente).......41

Figura 16 - Origem da Energia Térmica e sua Condução para o Exterior do Núcleo. ....42

Figura 17 - Esquema de Resfriamento do Núcleo de um Reator Nuclear. .......................43

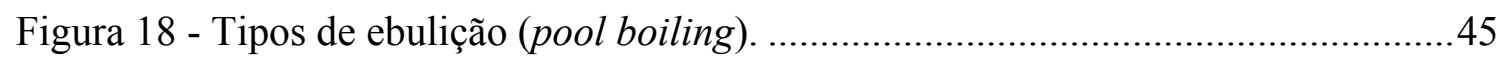

Figura 19 - Tipos de ebulição (Saturada e Sub-Resfriada). ............................................46

Figura 20 - Crescimento e liberação de uma bolha através da fenda presente em uma

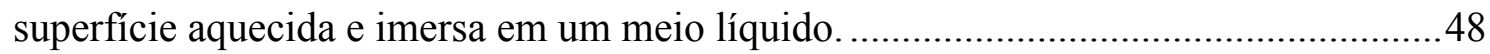

Figura 21 - Agitação da fase líquida na ebulição..........................................................50

Figura 22 - Regimes de Ebulição: até a, convecção; entre a e b, mistura (transição, início de bolhas isoladas); entre b e c, ebulição nucleada; entre c e d, transição (formação parcial de filme); entre d e e, ebulição com filme; entre e e f, ebulição com filme e

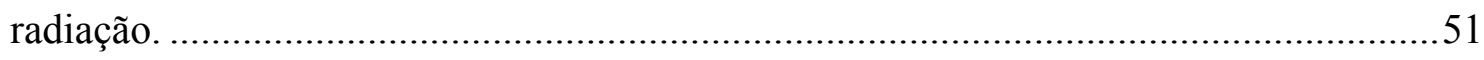

Figura 23 - Núcleo 5: Margens MDNBR e FIR ............................................................59

Figura 24 - Núcleo 6: Margens MDNBR e FIR..............................................................59 
Figura 25 - Núcleo 7: Margens MDNBR e FIR .60

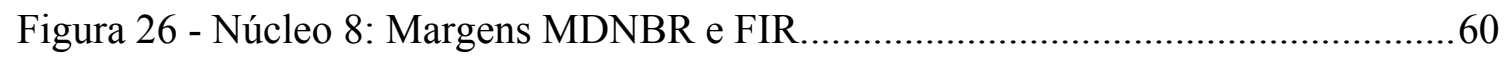

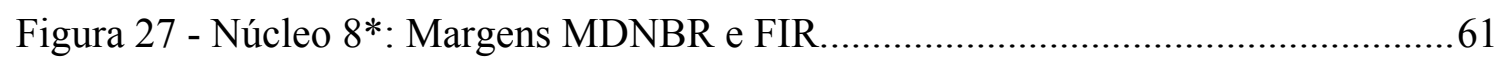

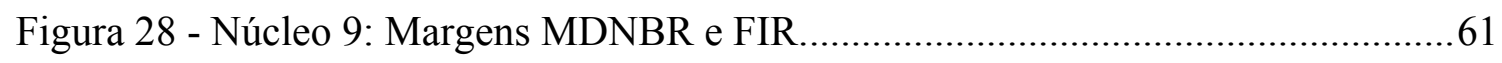

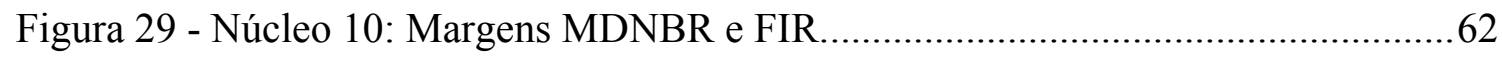

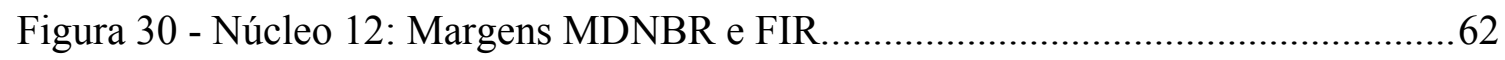

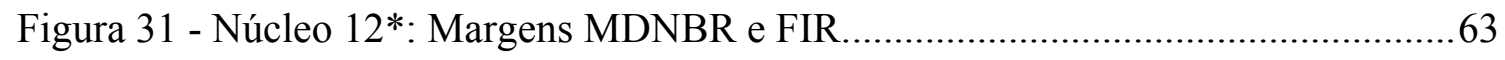

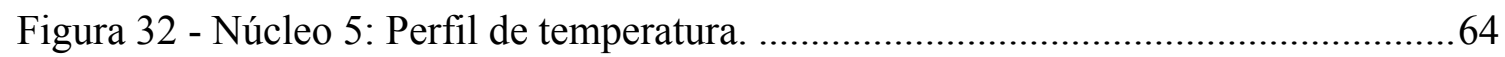

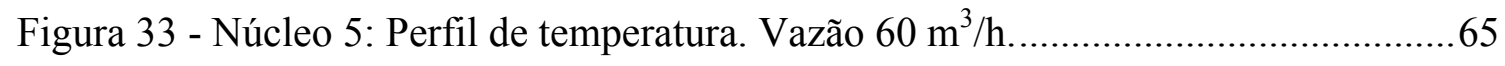

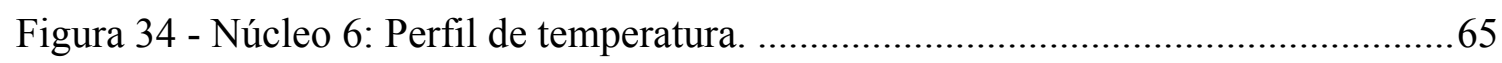

Figura 35 - Núcleo 6: Perfil de temperatura. Vazão $55 \mathrm{~m}^{3} / \mathrm{h}$.........................................66

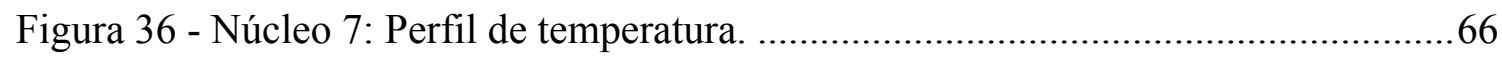

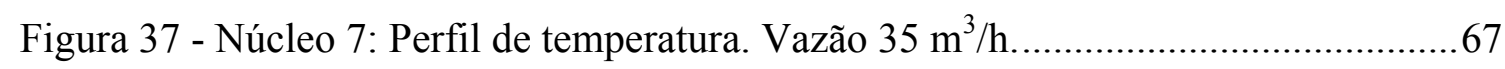

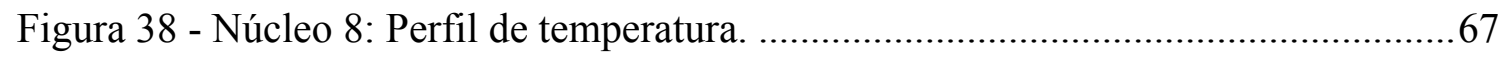

Figura 39 - Núcleo 8: Perfil de temperatura. Vazão $45 \mathrm{~m}^{3} / \mathrm{h}$.........................................6 68

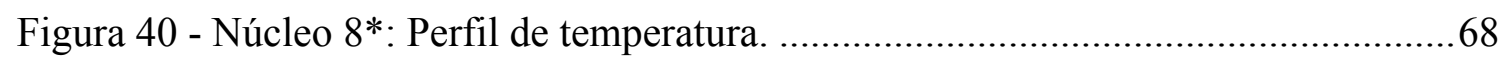

Figura 41 - Núcleo $8 *$ : Perfil de temperatura. Vazão $30 \mathrm{~m}^{3} / \mathrm{h}$......................................6. 69

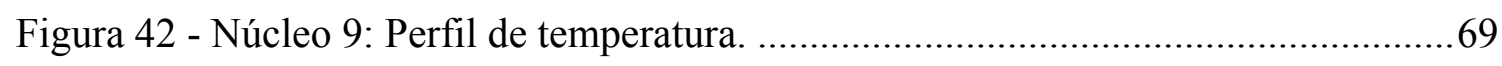

Figura 43 - Núcleo 9: Perfil de temperatura. Vazão $40 \mathrm{~m}^{3} / \mathrm{h}$........................................... 70

Figura 44 - Núcleo 10: Perfil de temperatura. ........................................................... 70

Figura 45 - Núcleo 10: Perfil de temperatura. Vazão $35 \mathrm{~m}^{3} / \mathrm{h}$....................................... 71

Figura 46 - Núcleo 12: Perfil de temperatura. ................................................................ 71

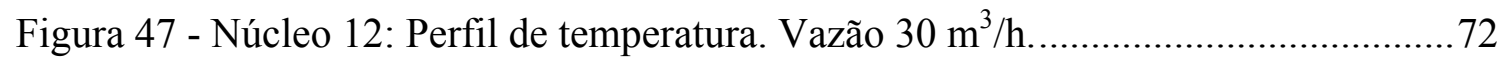

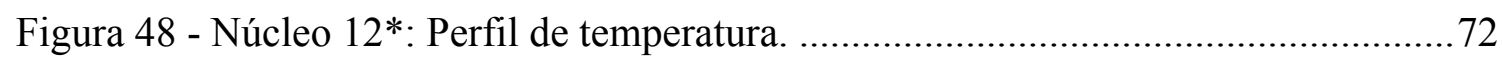

Figura 49 - Núcleo 12*: Perfil de temperatura. Vazão $20 \mathrm{~m}^{3} / \mathrm{h}$.................................... 73

Figura 50 - Esquema de duas placas combustíveis sujeitas a condições diferentes de carga com a existência do fenômeno de flambagem no segundo caso (Mecânico).........75

Figura 51 - Flambagem promovida por um gradiente de pressão via diferencial de

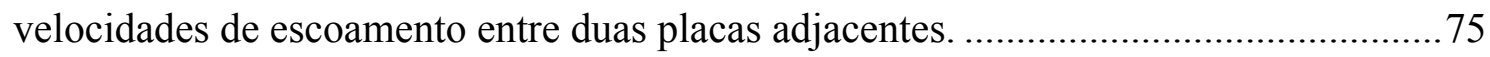

Figura 52 - Aumento na flambagem devido ao gradiente de pressão............................. 76

Figura 53 - Núcleo 8: Variação do fator de multiplicação com o tempo (queima). ........ 84

Figura 54 - Núcleo 8*: Variação do fator de multiplicação com o tempo (queima). .......84

Figura 55 - Núcleo 9: Variação do fator de multiplicação com o tempo (queima). ........85

Figura 56 - Núcleo 10: Variação do fator de multiplicação com o tempo (queima). ......85 
Figura 57 - Núcleos 5, 6 e 7. Pouco excesso de reatividade para a operação.

Figura 58 - Núcleo 8: Variação do fator de multiplicação e a produção de Xe-135 nos primeiros dias de operação do reator.

Figura 59 - Núcleo 8*: Variação do fator de multiplicação e a produção de Xe-135 nos

primeiros dias de operação do reator.

Figura 60 - Núcleo 9: Variação do fator de multiplicação e a produção de Xe-135 nos primeiros dias de operação do reator.

Figura 61 - Núcleo 10: Variação do fator de multiplicação e a produção de Xe-135 nos primeiros dias de operação do reator.

Figura 62 - Variação do Fator de multiplicação nas redondezas da criticalidade.

Figura 63 - Representação esquemática da piscina e ruptura na tubulação do IEA-R1. 93

Figura 64 - Ruptura na tubulação do circuito primário do reator IEA-R1 101

Figura 65 - Descobrimento do Núcleo - Ruptura dos Tubos SPI (linha vermelha: Altura na qual o núcleo se encontra completamente descoberto, 1,396m).

Figura 66 - Descobrimento do Núcleo - Ruptura dos Tubos de acesso SRA (linha vermelha: Altura na qual o núcleo se encontra completamente descoberto, 1,396m)..106 Figura 67 - Descobrimento do Núcleo - Ruptura da fronteira do circuito primário (linha vermelha: Altura na qual o núcleo se encontra completamente descoberto, 1,396m). .107 Figura 68 - Descobrimento do Núcleo - Abertura indevida dos drenos do SRA (linha vermelha: Altura na qual o núcleo se encontra completamente descoberto, 1,396m).. 108 Figura 69 - Descobrimento do Núcleo - Falha nos tubos colimadores [BH-3] (linha vermelha: Altura na qual o núcleo se encontra completamente descoberto, 1,396m). .109 Figura 70 - Fator de potência radial para as configurações 8, 8*, 9 e 10 (a cor vermelha simboliza elemento combustível e a laranja, elemento de controle).....

Figura 71 - Estudo paramétrico em TLAG para o núcleo 8. Metodologia para a

determinação do tempo de esvaziamento seguro do núcleo.

Figura 72 - Temperaturas atingidas após o descobrimento total do núcleo 8, referente ao caso mais extremo de esvaziamento da piscina (350s), via ruptura da fronteira do primário, operando $120 \mathrm{~h} / \mathrm{semana}$.

Figura 73 - Temperaturas atingidas após o descobrimento total do núcleo 8, operando 120h/semana. Tempo de esvaziamento seguro igual a 11,4h.

Figura 74 - Temperaturas atingidas após o descobrimento total do núcleo 8, operando 233 dias contínuos. Tempo de esvaziamento seguro igual a 4,2 dias. 
Figura 75 - Temperaturas atingidas após o descobrimento total do núcleo $8^{*}$, referente ao caso mais extremo de esvaziamento da piscina (350s), via ruptura da fronteira do primário, operando $120 \mathrm{~h} / \mathrm{semana}$.

Figura 76 - Temperaturas atingidas após o descobrimento total do núcleo $8 *$, operando 120h/semana. Tempo de esvaziamento seguro igual a $8,1 \mathrm{~h}$.

Figura 77 - Temperaturas atingidas após o descobrimento total do núcleo $8^{*}$, operando 233 dias contínuos. Tempo de esvaziamento seguro igual a 2,7 dias.

Figura 78 - Temperaturas atingidas após o descobrimento total do núcleo 9, referente ao caso mais extremo de esvaziamento da piscina (350s), via ruptura da fronteira do primário, operando $120 \mathrm{~h} / \mathrm{semana}$.

Figura 79 - Temperaturas atingidas após o descobrimento total do núcleo 9, operando $120 \mathrm{~h} / \mathrm{semana}$. Tempo de esvaziamento seguro igual a $8,9 \mathrm{~h}$.

Figura 80 - Temperaturas atingidas após o descobrimento total do núcleo 9, operando 233 dias contínuos. Tempo de esvaziamento seguro igual a 3,2 dias.

Figura 81 - Temperaturas atingidas após o descobrimento total do núcleo 10, referente ao caso mais extremo de esvaziamento da piscina (350s), via ruptura da fronteira do primário, operando $120 \mathrm{~h} / \mathrm{semana}$.

Figura 82 - Temperaturas atingidas após o descobrimento total do núcleo 10, operando

120h/semana. Tempo de esvaziamento seguro igual a 10,7h. 120

Figura 83 - Temperaturas atingidas após o descobrimento total do núcleo 10, operando 233 dias contínuos. Tempo de esvaziamento seguro igual a 3,8 dias.

Figura 84 - Temperaturas atingidas após o descobrimento total do núcleo atual do reator IEA-R1, operando 233 dias contínuos. Tempo de esvaziamento seguro igual a 10,7h.

Figura 85 - Temperaturas atingidas após o descobrimento total do núcleo atual do reator IEA-R1, operando 120h semanais. Tempo de esvaziamento seguro igual a 1,5h.......126 


\section{Lista de Tabelas}

Tabela 1 - Cálculo do keff e Excesso de Reatividade $\left(\rho_{e x}\right)$ para os novos núcleos do reator IEA-R1

Tabela 2 - Cálculo da margem de desligamento $(\rho S M)$ e do valor total dos elementos de controle $\Delta \rho$ para os novos núcleos do reator IEA-R1.

Tabela 3 - Densidade de potência média na placa combustível mais quente em cada uma das novas configurações

Tabela 4 - Valores mínimos para as margens MDNBR e FIR

Tabela 5 - Geometria dos elementos combustíveis, pressão de operação e temperatura de entrada do refrigerante.

Tabela 6 - Velocidades nos canais de resfriamento e a velocidade crítica permitida para cada nova configuração.

Tabela 7 - Cálculo do coeficiente de temperatura $(\alpha T)$.

Tabela 8 - Avaliação do fator de multiplicação nos arredores da criticalidade.

Configurações $8,8^{*}, 9$ e 10 . 89

Tabela 9 - Queima média do combustível para o núcleo 8 ao longo do tempo. 89

Tabela 10 - Queima média do combustível para o núcleo $8^{*}$ ao longo do tempo.

Tabela 11 - Queima média do combustível para o núcleo 9 ao longo do tempo. . .90

Tabela 12 - Queima média do combustível para o núcleo 10 ao longo do tempo. .90

Tabela 13 - Dados de entrada do programa LOSS 103

Tabela 14 - Dados de entrada do programa LOSS: Ruptura dos tubos do SPI. 104

Tabela 15 - Dados de entrada do programa LOSS: Ruptura dos tubos de acesso SRA.105 Tabela 16 - Dados de entrada do programa LOSS: Ruptura da fronteira do circuito primário.

Tabela 17 - Dados de entrada do programa LOSS: Ruptura da fronteira do circuito primário.

Tabela 18 - Dados de entrada do programa LOSS: Falha nos tubos colimadores (BH-3).

Tabela 19 - Dados de entrada do programa TEMPLOCA. 
Tabela 20 - Potência média por placa combustível, Fator de potência radial e potência máxima por elemento

Tabela 21 - Dados de entrada do programa TEMPLOCA para o cálculo da temperatura nas miniplacas do elemento mais quente dentre todos os núcleos apresentados. .........114 Tabela 22 - Novos núcleos e os fluxos neutrônicos térmicos médios estimados na região ativa das novas configurações 


\section{Sumário}

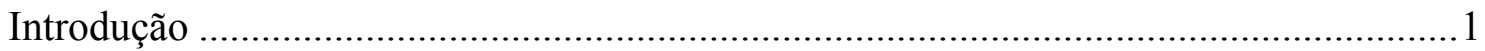

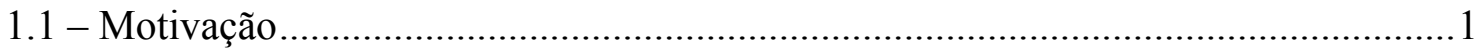

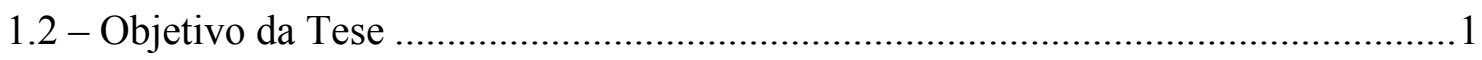

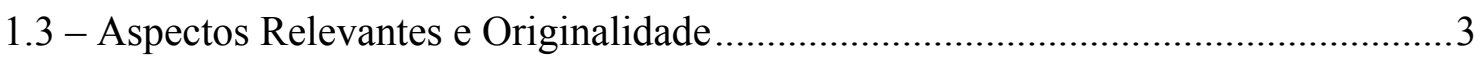

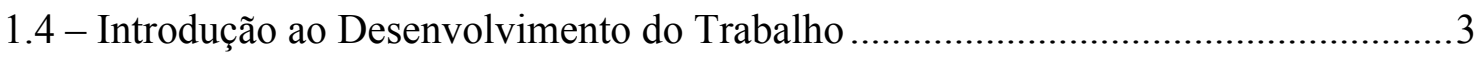

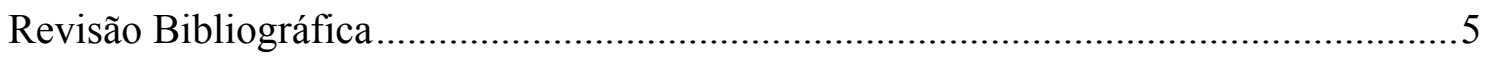

2.1 - Miniplacas Combustíveis de $\mathrm{U}_{3} \mathrm{Si}_{2}-\mathrm{Al}$ do IPEN/CNEN-SP ..................................5

2.2 - Redução de Núcleos de Reatores de Pesquisa ......................................................... 9

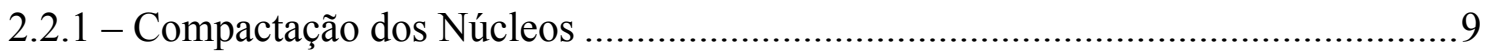

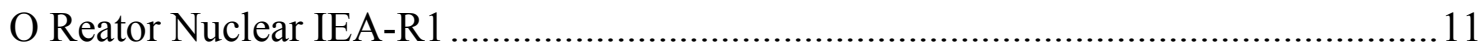

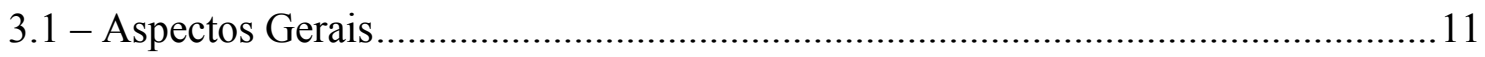

3.2 - A Evolução do Núcleo do Reator IEA-R1 ......................................................... 12

Introdução aos Aspectos Teóricos Fundamentais ...................................................... 14

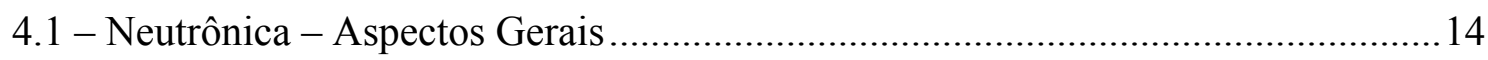

4.2 - Termo-Hidráulica de Reatores - Aspectos Gerais ............................................ 17

4.2.1 - Critérios de Projeto para Combustíveis MTR - Condições Normais de Operação

Metodologia Para Análise Neutrônica e Termo-Hidráulica.......................................... 19

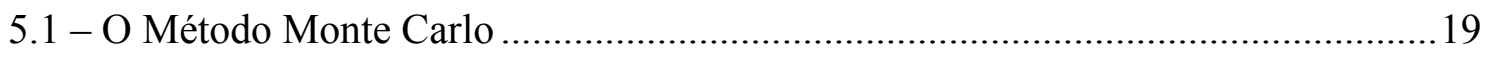

5.2 - O Modelo Térmico MTRCR-IEAR1 ….............................................................2 21

Novos Núcleos para o Reator IEA-R1: Análise Neutrônica .........................................24

6.1 - Novos Núcleos: Configurações e Nomenclatura ................................................24

6.1.1 - Novos Núcleos: Criticalidade, Excesso de Reatividade, Margem de

Desligamento (Shutdown Margin) e Valor Total dos Elementos de Controle (Total

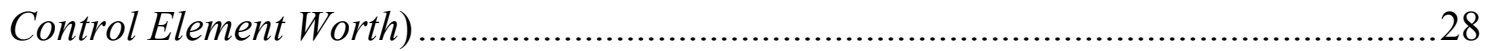

6.1.2 - Novos Núcleos: Densidade de Potência e Determinação dos Fatores de Pico para

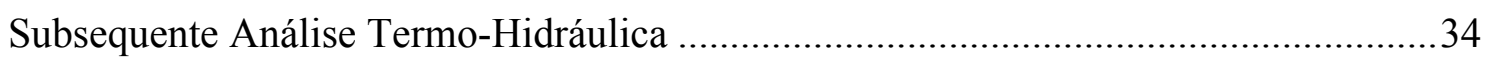

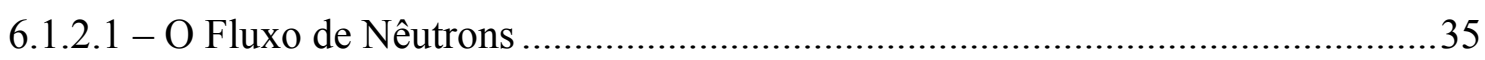




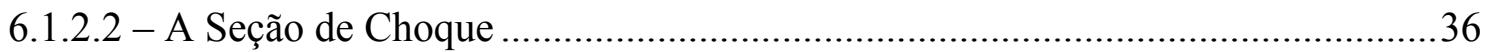

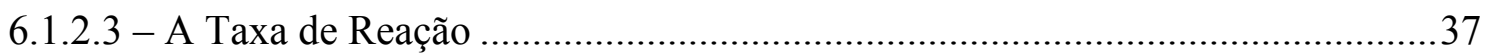

Novos Núcleos para o Reator IEA-R1: Análise Termo-Hidráulica...............................42

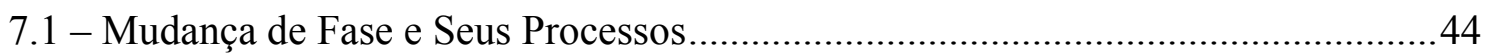

7.1.1 - Mudança de Fase e Seus Processos: Evaporação e Ebulição............................... 44

7.1.2 - Mudança de Fase e Seus Processos: Escoamento Bifásico..................................46

7.1.3 - Mudança de Fase e Seus Processos: Condensação ...............................................47

7.2 - Formação de Bolhas, Crescimento e Desprendimento .........................................47

7.2.1 - Formação de Bolhas, Crescimento e Desprendimento: Subsídios para Nucleação

7.2.3 - Formação de Bolhas, Crescimento e Desprendimento: Líquido Superaquecido 48

7.2.4 - Formação de Bolhas, Crescimento e Desprendimento: Desprendimento das

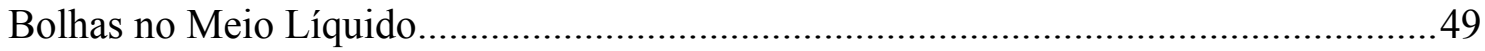

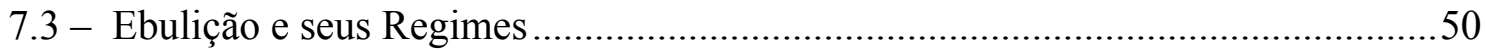

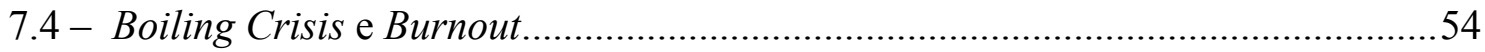

7.5 - Cálculo das Margens de Segurança MDNBR e FIR, Temperatura de ONB, Perfis de Temperatura para o Canal mais Quente de Cada Configuração e Velocidade Crítica

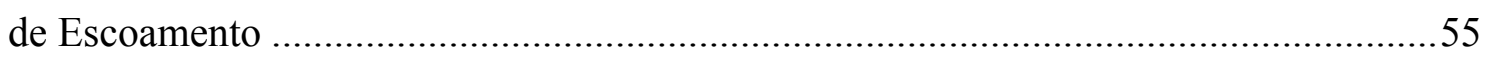

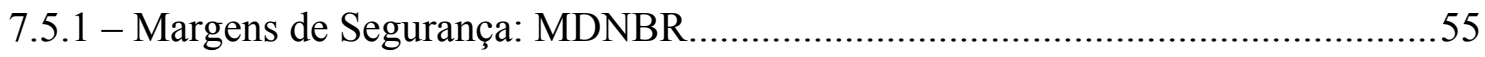

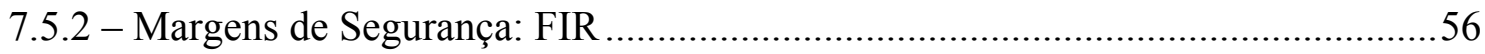

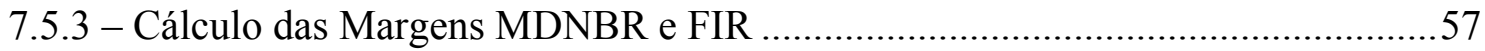

7.5.4 - Cálculo dos Perfis de Temperatura e Temperatura de ONB ..............................63

7.5.5 - Cálculo da Velocidade Crítica de Escoamento .................................................... 74

Novos Núcleos para o Reator IEA-R1: Verificação do Coeficiente de Temperatura e a

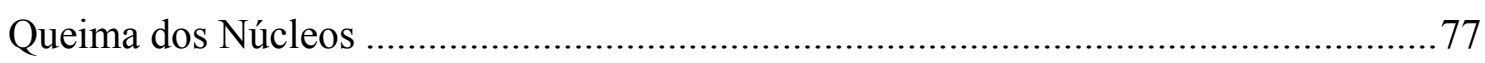

8.1 - Verificação do Coeficiente de Reatividade de Temperatura $\alpha \mathrm{T}$............................ 77

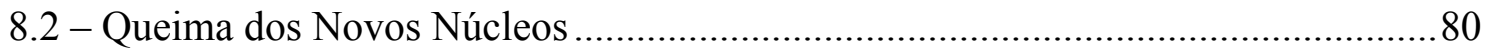

Novos Núcleos para o Reator IEA-R1: Simulação de um APR ....................................91

9.1 - Metodologia para a Simulação de APR ................................................................. 92

9.2 - Cálculo do Tempo de Esvaziamento da Piscina .................................................... 93

9.3 - O Programa LOSS e os Eventos Postulados para o Reator IEA-R1 ..................... 102

9.3.1 - Ruptura dos Tubos do Sistema Pneumático de Irradiação (SPI) ...................... 103

9.3.2 - Falhas nos Drenos da Piscina - Ruptura dos Tubos de Acesso SRA ................ 104 
9.3.3 - Ruptura da Fronteira do Circuito Primário ........................................................... 106

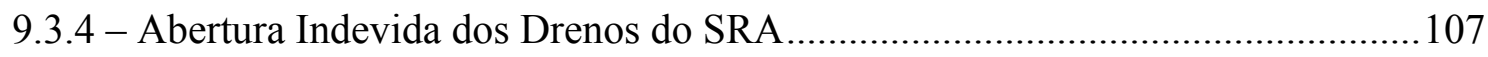

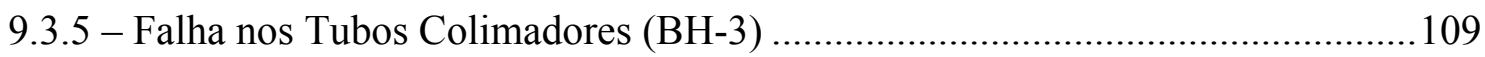

9.4 - O Programa TEMPLOCA e a Temperatura Máxima Atingida ........................... 110

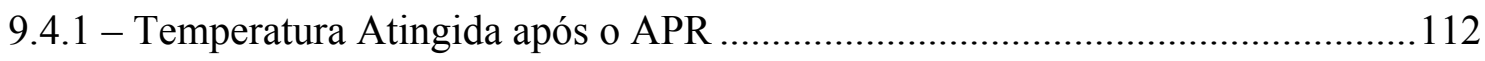

Novos Núcleos para o Reator IEA-R1: Comentários e Discussões dos Resultados.... 121

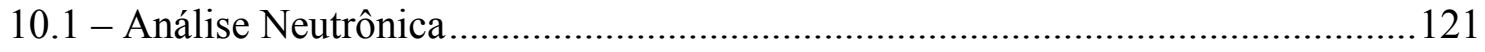

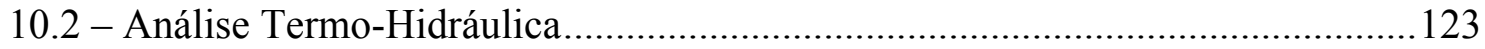

10.3 - Verificação dos Coeficientes de Temperatura e a Queima dos Núcleos ............124

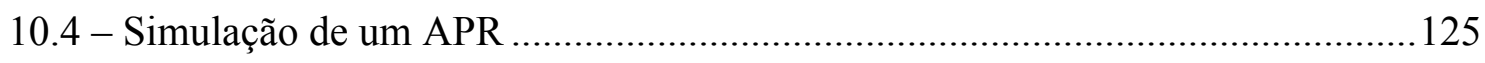

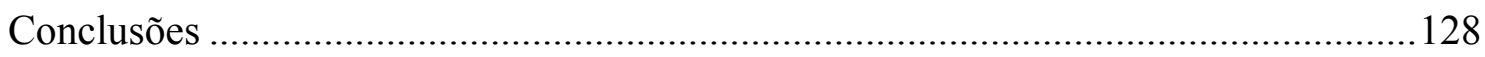

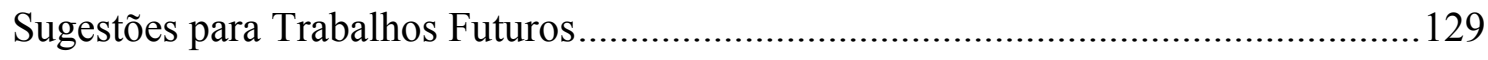

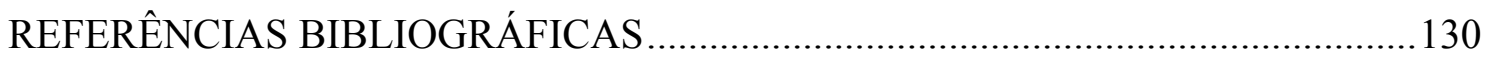

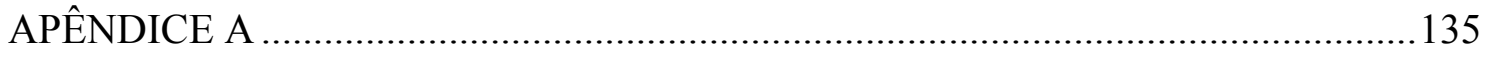

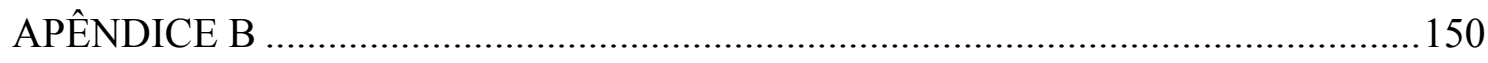

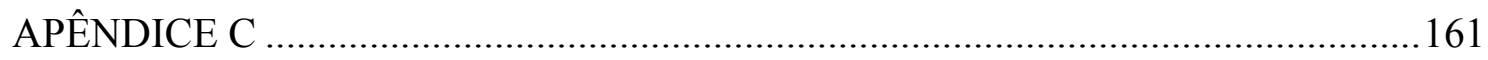

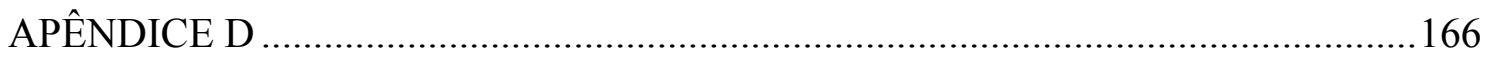

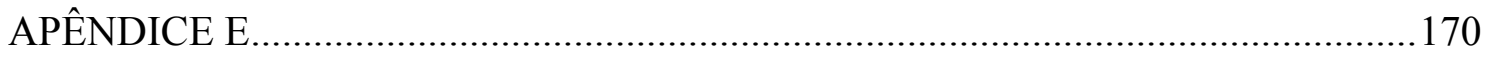




\section{Introdução}

\section{1 - Motivação}

O reator nuclear IEA-R1 é um reator de pesquisa tipo piscina aberta projetado para operar a uma potência máxima de $5 \mathrm{MW}$ e desempenha funções importantes dentro do IPEN/CNEN-SP, assim como perante toda a sociedade. Além dos centros de pesquisas que compõe o IPEN, diversos outros institutos e empresas privadas utilizam dos serviços de irradiação que esse reator fornece. A redução do atual núcleo do reator poderá gerar uma série de benefícios futuros (i.e., aumento dos fluxos térmicos e rápidos, maior geração de radioisótopos para fins medicinais e uso da sociedade, menores tempos de irradiação de materiais, etc.).

Fatos como esses motivaram o desenvolvimento do presente trabalho, a fim de se encontrar e mostrar factível novas configurações para o núcleo do reator IEA-R1 que possam atender de forma satisfatória às necessidades do IPEN/CNEN-SP e da sociedade no futuro, sem alteração brusca das variáveis, principalmente as geométricas, utilizadas na configuração atual. Devido a sua idade avançada, o momento nunca foi tão oportuno para se discutir uma nova possibilidade de modernização para o núcleo atual desse reator.

\section{2 - Objetivo da Tese}

O principal objetivo deste trabalho de doutorado é pesquisar a possibilidade de reduzir o núcleo do reator IEA-R1, analisando, computacionalmente, diferentes configurações que possam, no futuro, se necessário, substituir a atual configuração $5 \times 5$. Para tal, faz-se necessário responder algumas questões fundamentais, tais como: 
- As densidades de potência geradas nas novas configurações possibilitam uma operação segura dos núcleos do ponto de vista neutrônico, termo-hidráulico e de segurança?

- Os perfis de temperatura nos novos núcleos são compatíveis com os limites de projeto?

- As novas configurações possuem excesso de reatividade suficiente para funcionamento?

- Os coeficientes de temperatura são todos negativos?

- Como seria o comportamento das novas configurações frente a um acidente de perda de refrigerante (APR)?

- Qual seria o tempo seguro para o esvaziamento dos núcleos sem que a temperatura ultrapasse aquela referente ao limite de projeto do combustível nuclear?

Assim, o estudo não se resume a encontrar uma configuração em particular que atenda todas as expectativas da sociedade, pois isso seria impossível. Ao contrário, o trabalho tem como meta pesquisar e mostrar factível a redução do atual núcleo para configurações menores, sem prejuízos termo-hidráulicos e de segurança, avaliando parâmetros como os mencionados anteriormente. A escolha por um ou outro arranjo, ou mesmo por uma configuração diferente daquelas sugeridas por este trabalho, dependerá da finalidade principal que o reator terá no futuro, logo, diversos núcleos foram construídos e estudados. Dentre as várias funções, a aplicação de reatores nucleares de pesquisa na saúde e para fins medicinais é sem dúvida o maior apelo para a modificação do atual núcleo do reator IEA-R1, sendo que o aumento dos fluxos de nêutrons térmicos implica também em uma maior produção de radioisótopos, utilizados por hospitais e clínicas para tratamento.

Reduções em núcleos de reatores nucleares já foram realizadas anteriormente (como no reator alemão FRG-1 e até mesmo no próprio reator IEA-R1 no passado), proporcionando uma série de benefícios, conforme já mencionados. Assim, o apelo social motivou o desenvolvimento desse trabalho de doutorado, haja vista que o maior beneficiário futuro do mesmo será a sociedade brasileira. 
Foram estudadas configurações desde $3 \times 3$ (9 elementos) até 4x4 (16 elementos). Para as novas configurações pertinentes, foram realizadas as análises neutrônica e termohidráulica, além da identificação dos eventos iniciadores postulados, isto é, as ocorrências que podem conduzir a cenários de acidentes de perda de refrigerante (APR).

\section{3 - Aspectos Relevantes e Originalidade}

Este trabalho contribui com estudos e informações referentes a novos núcleos para o reator IEA-R1. O estudo confirma a existência de configurações mais compactas e igualmente seguras para substituir o atual arranjo $5 \times 5$.

Também deve-se destacar que os estudos realizados aqui contribuem para futuros trabalhos e análises que possam vir a ser desenvolvidos no contexto da redução e/ou modificação do núcleo atual do reator IEA-R1.

A análise completa dessas novas configurações, através das análises neutrônica, termohidráulica e de segurança, constituindo o foco primário do presente trabalho de doutorado, origina um importante documento e ponto de partida para pesquisas futuras, somando conhecimentos e informações relevantes para futuras modificações no núcleo do reator IEA-R1.

\section{4 - Introdução ao Desenvolvimento do Trabalho}

Após o Capítulo 2 (revisão bibliográfica), o Capítulo 3 apresenta, brevemente, informações pertinentes a respeito do reator IEA-R1 e sua história. O Capítulo 4 introduz os aspectos teóricos fundamentais que dão suporte ao trabalho desenvolvido na presente tese. No Capítulo 5, encontram-se as metodologias para as análises neutrônica e termo-hidráulica. No Capítulo 6 e 7, encontram-se, respectivamente, as análises neutrônica e termo-hidráulica aplicadas aos novos núcleos estudados.

No capítulo 8, o coeficiente de temperatura e a queima dos núcleos são analisados e no Capítulo 9, tem-se o desenvolvimento da simulação de um acidente de perda de refrigerante (APR). 
No Capítulo 10, tem-se a discussão e os comentários referentes aos resultados obtidos e o Capítulo 11 apresenta as conclusões do estudo. Sugestões para trabalhos futuros estão dispostas no capítulo 12 . 


\section{Revisão Bibliográfica}

\section{1 - Miniplacas Combustíveis de $\mathrm{U}_{3} \mathrm{Si}_{2}$-Al do IPEN/CNEN-SP}

O IPEN-CNEN/SP desenvolveu nos últimos anos a fabricação de combustíveis a dispersão de $\mathrm{U}_{3} \mathrm{O}_{8}-\mathrm{Al}$ e $\mathrm{U}_{3} \mathrm{Si}_{2}-\mathrm{Al}[1,2]$. O combustível de $\mathrm{U}_{3} \mathrm{O}_{8}-\mathrm{Al}$ fabricado pelo IPEN, encontra-se qualificado até uma densidade de $2,3 \mathrm{gU} / \mathrm{cm}^{3}(33 \%$ em volume da fase $\left.\mathrm{U}_{3} \mathrm{O}_{8}\right)$ e o de $\mathrm{U}_{3} \mathrm{Si}_{2}-\mathrm{Al}$, até uma densidade de $3,0 \mathrm{gU} / \mathrm{cm}^{3}(26 \%$ em volume da fase $\mathrm{U}_{3} \mathrm{Si}_{2}$ ). O núcleo do reator IEA-R1 é hoje composto por esses combustíveis, utilizando baixo enriquecimento de urânio (Low Enriched Uranium - LEU - 19,9\% de U-235) e pode operar até uma potência de $5 \mathrm{MW}$.

Os elementos combustíveis a dispersão, $\mathrm{U}_{3} \mathrm{O}_{8}-\mathrm{Al}$ e $\mathrm{U}_{3} \mathrm{Si}_{2}-\mathrm{Al}$, fabricados no IPENCNEN/SP, seguem rigorosas especificações técnicas, que foram definidas após cuidadosas revisões bibliográficas abrangendo a experiência mundial no projeto, fabricação e análise do desempenho sob irradiação de combustíveis a dispersão. Entretanto, a garantia de um bom desempenho sob irradiação só pode ser confirmada através de minuciosos exames pós-irradiação.

No Brasil, não existem reatores de alto fluxo neutrônico, como os reatores OPAL (20MW, Autrália) [3] e o reator HFIR (85MW, Estados Unidos) [4], onde se possa irradiar mini-placas combustíveis e atingir queimas elevadas em tempos de irradiação curtos, nas quais os danos no combustível apareçam em maior escala. Também não existem "células quentes", em que os danos no combustível possam ser examinados através de testes destrutivos.

A qualificação dos elementos combustíveis fabricados no IPEN-CNEN/SP foi realizada diretamente no reator IEA-R1, através de um programa de acompanhamento da irradiação $[1,5,6]$. Nesse programa, o elemento combustível foi colocado diretamente no reator e em seguida foi inspecionado visualmente em tempos determinados, até atingir a 
queima estipulada para a sua qualificação e, como visto anteriormente, os combustíveis $\mathrm{U}_{3} \mathrm{O}_{8}-\mathrm{Al}$ e $\mathrm{U}_{3} \mathrm{Si}_{2}-\mathrm{Al}$, com densidades de $2,3 \mathrm{gU} / \mathrm{cm}^{3}$ e $3,0 \mathrm{gU} / \mathrm{cm}^{3}$, respectivamente, foram qualificados até uma queima de aproximadamente $45 \%$ de U-235.

Todavia, permanecia no instituto o interesse em fabricar combustíveis do tipo dispersão com densidades de urânio mais elevadas de forma a atingir as densidades máximas qualificadas no mundo, ou seja, $3,0 \mathrm{gU} / \mathrm{cm}^{3}$ e $4,8 \mathrm{gU} / \mathrm{cm}^{3}$, para os combustíveis $\mathrm{U}_{3} \mathrm{O}_{8}-\mathrm{Al}$ e $\mathrm{U}_{3} \mathrm{Si}_{2}-\mathrm{Al}$, respectivamente.

Havia, porém, o receio de se colocar para irradiação no reator IEA-R1 elementos combustíveis completos com essas densidades de urânio, sem antes desenvolver testes através de irradiações de miniplacas combustíveis. O uso de miniplacas para a determinação inicial das propriedades básicas de irradiação é vantajosa, uma vez que essas são mais fáceis de fabricar em escala laboratorial e requerem menores quantidades de material combustível e, consequentemente, um maior número de amostras pode ser irradiado em um dado volume ou dispositivo de irradiação, possibilitando a verificação de um número maior de variáveis como as referentes ao combustível, revestimento e/ou métodos de fabricação.

Adicionalmente, as consequências da falha de uma miniplaca combustível para a operação do reator são baixas, devido às pequenas quantidades de combustível presentes. Assim, a principal meta da irradiação é identificar as propriedades básicas da parte ativa do combustível, tais como a interação combustível-matriz e o inchamento do mesmo.

No ano de 2007, houve a substituição do trocador de calor do reator IEA-R1, o que possibilitou a oportunidade de ampliar, com segurança, a sua potência de operação de 3 MW para 5 MW. Operando nessa potência, seria possível atingir queimas mais elevadas do combustível com tempos de irradiação menores.

Logo, diferente do processo de qualificação até então conduzido, que considerava apenas a irradiação direta de elementos combustíveis completos e com mais baixas densidades, foi proposto colocar no reator IEA-R1 miniplacas combustíveis de $\mathrm{U}_{3} \mathrm{O}_{8}-\mathrm{Al}$ 
e $\mathrm{U}_{3} \mathrm{Si}_{2}-\mathrm{Al}$,fabricadas no IPEN-CNEN/SP, com as densidades máximas qualificadas no mundo e acompanhar o seu desempenho sob irradiação.

Em caso de um bom desempenho, seriam construídos elementos combustíveis completos nessas densidades para posterior utilização no reator IEA-R1. Isso possibilitaria uma melhor utilização do combustível e a possibilidade de reduzir o volume do núcleo do reator (motivação para o desenvolvimento desse trabalho).

Para alojar as miniplacas combustíveis durante a irradiação no reator IEA-R1, foi projetado e construído um "dispositivo de irradiação de miniplacas" (DIM) [7], que possui dimensões externas próximas daquelas do combustível padrão do reator IEA-R1. No interior do DIM, foi inserido um estojo que permite a colocação de até dez miniplacas combustíveis de $\mathrm{U}_{3} \mathrm{O}_{8}-\mathrm{Al}$ e/ou $\mathrm{U}_{3} \mathrm{Si}_{2}-\mathrm{Al}$ [8].

A introdução de qualquer dispositivo de irradiação no núcleo do reator, que necessite de resfriamento, deve ser devidamente analisada, de forma a avaliar o seu impacto no resfriamento do núcleo, garantindo assim que o resfriamento do mesmo não seja comprometido, assim como garantindo o resfriamento adequado das miniplacas que serão irradiadas. Estudos neutrônicos e termo-hidráulicos referentes ao dispositivo de irradiação foram conduzidos, considerando as possíveis posições para a colocação desse dispositivo de irradiação no reator IEA-R1 [7].

O comportamento termo-hidráulico do DIM foi avaliado por meio de experimentos realizados no Centro de Engenharia Nuclear (CEN) do IPEN/CNEN-SP. Esses experimentos conduziram à colocação de uma placa limitadora de vazão (PLV) no interior do DIM, a qual limita a vazão nesse dispositivo em $13 \mathrm{~m}^{3} / \mathrm{h}$ [9]. Para acompanhar o desempenho das miniplacas, um conjunto de testes não destrutivos está sendo realizado periodicamente na piscina de estocagem dos combustíveis irradiados do reator IEA-R1. Esses testes consistem da inspeção visual das miniplacas irradiadas e da medida da espessura das mesmas para verificar o inchamento do combustível ao longo da irradiação [5]. 
Nos anos de 2009 a 2011, foram realizadas reuniões técnicas junto ao Centro do Reator de Pesquisa (CRPq) do IPEN e ao órgão licenciador (CNEN-RJ) para aprovação do programa experimental e licença para início da irradiação das miniplacas no reator IEAR1. As miniplacas combustíveis foram fabricadas no Centro do Combustível Nuclear (CCN) no IPEN.

Dentre as miniplacas fabricadas pelo $\mathrm{CCN}$, dez foram selecionadas para os testes de irradiação no IEA-R1, sendo cinco com $\mathrm{U}_{3} \mathrm{Si}_{2}-\mathrm{Al}$ e cinco com $\mathrm{U}_{3} \mathrm{O}_{8}-\mathrm{Al}$. Dentre as miniplacas com $\mathrm{U}_{3} \mathrm{Si}_{2}-\mathrm{Al}$, três possuíram $4,8 \mathrm{gU} / \mathrm{cm}^{3}$ e duas $3,0 \mathrm{gU} / \mathrm{cm}^{3}$. Da mesma forma, entre as miniplacas com $\mathrm{U}_{3} \mathrm{O}_{8}-\mathrm{Al}$, três possuíram $3,2 \mathrm{gU} / \mathrm{cm}^{3}$ e duas $2,3 \mathrm{gU} / \mathrm{cm}^{3}$.

A irradiação de algumas miniplacas contendo as densidades atualmente empregadas na fabricação dos elementos combustíveis do reator IEA-R1 foi adotada para permitir a comparação dos comportamentos de irradiação com aquelas de alta densidade. $\mathrm{O}$ material do revestimento utilizado é o alumínio Al-6061-T0.

O DIM foi carregado em 30/05/2011 na posição 36 da placa matriz do reator IEA-R1, numa posição periférica do núcleo, na configuração 246. Utilizando o programa computacional CITATION [10], foram obtidos os fluxos de nêutrons térmicos e rápidos para as posições das miniplacas no DIM nessa configuração. As seções de choque dos materiais do DIM foram geradas pelo programa computacional HAMMERTECHNION [11] e utilizadas como dados de entrada para o CITATION.

Estudos desenvolvidos recentemente na tese de doutorado de José Eduardo Rosa da Silva [8] demonstraram que para atingir as queimas de 50\% e 80\% de U-235 nas miniplacas combustíveis, exigidos para qualificação do combustível $\mathrm{U}_{3} \mathrm{Si}_{2}-\mathrm{Al}$ com densidade de $4,8 \mathrm{gU} / \mathrm{cm}^{3}$, seriam necessários tempos de irradiação de 6 a 10 anos, respectivamente, caso a potencia do reator fosse $5 \mathrm{MW}$ e 120 horas semanais de operação. 


\section{2 - Redução de Núcleos de Reatores de Pesquisa}

A conversão de núcleos de reatores de pesquisa para configurações mais compactas ocorre e já ocorreram em diversos países, inclusive com o próprio reator IEA-R1, como será visto no Capítulo 3.

O reator Alemão FRG-1[12], cuja primeira criticalidade ocorreu no dia 23 de outubro de 1958, por exemplo, já passou por duas reduções de núcleo. A primeira delas ocorreu em 1991, durante a conversão do núcleo de HEU (93\%) para LEU (20\%), onde seus 48 elementos combustíveis foram substituídos por apenas 26 .

Essa compactação proporcionou um aumento (por um fator 2) no fluxo térmico na posição dos tubos de irradiação [12]. Na década de 90, uma nova redução para o núcleo do reator FRG-1 foi proposta de forma a utilizar somente 12 elementos combustíveis, sendo a redução total de 48 elementos (início) para 12 (final). Para se atingir tal objetivo, a densidade de urânio no combustível $\left(\mathrm{U}_{3} \mathrm{Si}_{2}\right)$ teve que ser aumentada de $3,7 \mathrm{gU} / \mathrm{cm}^{3}$ para $4,8 \mathrm{gU} / \mathrm{cm}^{3}$.

\subsection{1 - Compactação dos Núcleos}

De acordo com os conceitos para compactação de núcleos de reatores de pesquisa [13], o volume (V) do mesmo deve ser o menor possível a uma potência constante de operação $(\mathrm{P})$; o núcleo reduzido deve ser rodeado com moderador (refletor) de alta qualidade e grande volume, a fim de se maximizar a produção de nêutrons térmico; o valor da potência $(\mathrm{P})$ deve ser escolhido o mais alto possível para se obter um alto valor absoluto para o fluxo térmico.

Ainda em relação à compactação de núcleos, algumas vantagens aparentes são: o alto fator de qualidade (fluxo térmico máximo/volume); o grande volume disponível para usos diversos (aumento do volume efetivo na região do refletor); alta pureza espectral do fluxo de nêutrons térmicos $[13,14]$. 
Para que se possa explorar todos os benefícios da compactação/redução em núcleos de reatores de pesquisa, como é o caso do reator IEA-R1, deve-se garantir que certas variáveis e parâmetros estejam dentro ou obedeçam aos limites de projeto e controle. Para tal, um conjunto de análises deve ser realizado para garantir o funcionamento seguro do núcleo do reator.

Esse é o foco central do presente trabalho, avaliar as novas configurações (menores) propostas para o núcleo do reator IEA-R1 de forma a garantir que nenhuma margem termo-hidráulica, temperatura ou parâmetros de segurança estejam fora dos valores previstos e limites de projetos, utilizando ferramentas computacionais e técnicas matemáticas bem estabelecidas. 


\section{O Reator Nuclear IEA-R1}

Ao longo dos anos 50, muitos reatores de pesquisa foram construídos ao redor do mundo, sendo cerca de 286 comissionados nessa década em particular. Entretanto, nos dias atuais, menos da metade desses reatores ainda permanecem em operação. Em países em desenvolvimento como o Brasil, os reatores de pesquisa eram implementados através de programas como "Atoms for Peace".

No geral, esses reatores eram construídos sem um propósito claro, sem uma necessidade prévia, sendo meramente um símbolo. Possuir um reator de pesquisa era sinônimo de nação "civilizada", não importando a sua função.

O reator nuclear IEA-R1 teve sua construção iniciada em 1956, sendo terminada um ano mais tarde e, na data de 16 de setembro de 1957, obteve sua primeira criticalidade (a primeira de todo hemisfério sul). Durante os primeiros anos de funcionamento, o reator IEA-R1 operou a uma potência de 1MW.

Com o passar dos anos, essa potência de operação foi aumentada (2MW, de 1960 a 1995, por exemplo), atingindo o limite de projeto, 5MW, em 16 de setembro de 1997.

Em 2007, houve a substituição de um dos trocadores de calor do reator IEA-R1, o que possibilitou a sua operação com segurança até uma potência de 5MW.

\section{1 - Aspectos Gerais}

O reator de pesquisa IEA-R1 é um reator tipo piscina, resfriado e moderado a água leve desmineralizada e refletido a grafite. Foi desenvolvido pela empresa Babcock \& Wilcox Co., dentro do programa "Atoms for Peace". 
Esse reator está localizado no Instituto de Pesquisas Energéticas e Nucleares - IPEN, dentro do campus da Universidade de São Paulo. O núcleo do reator, os refletores de grafite e os elementos de irradiação estão dispostos em uma grade $8 \times 10$. Atualmente, o núcleo é composto de um arranjo 5x5 (Figura 1), com elementos combustíveis (20), elementos de controle (4) e um irradiador central de Berílio. As placas de controle, inseridas nos elementos de controle, são do tipo Ag-In-Cd.

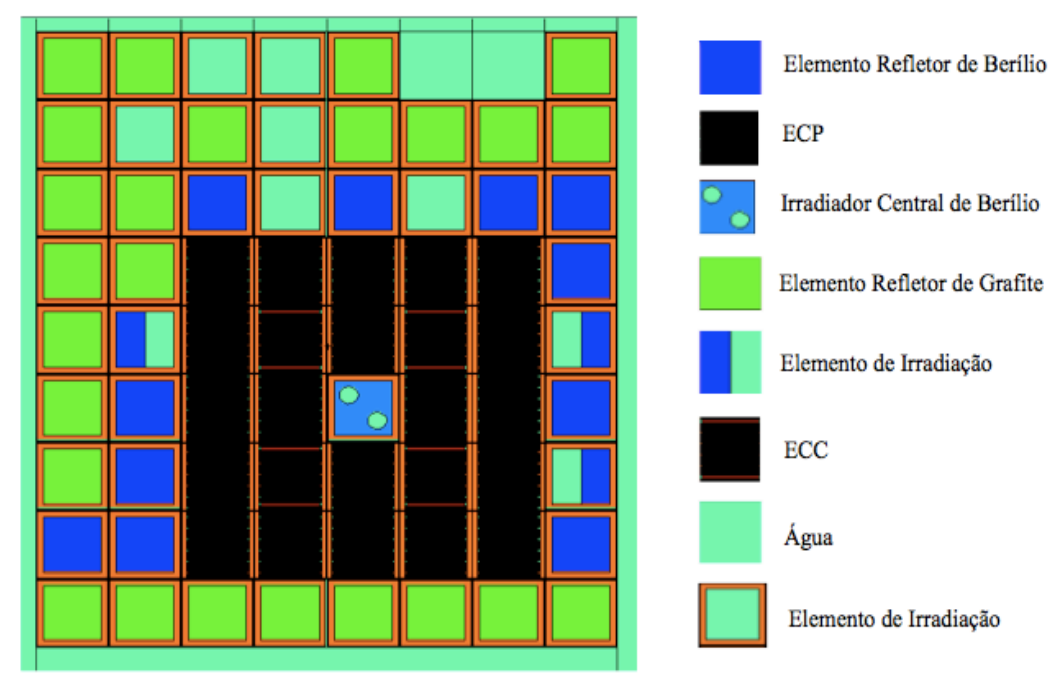

Figura 1- Visão superior do núcleo atual, 5x5 do reator IEA-R1 (MCNP).

A configuração atual possui combustíveis de $\mathrm{U}_{3} \mathrm{O}_{8}-\mathrm{Al}$ e $\mathrm{U}_{3} \mathrm{Si}_{2}-\mathrm{Al}$, com baixo enriquecimento de urânio (LEU, 19,9\% em Urânio -235), contendo, respectivamente, $2,3 \mathrm{gU} / \mathrm{cm}^{3}$ ( $33 \%$ de $\mathrm{U}_{3} \mathrm{O}_{8}$ em volume) e $3,0 \mathrm{gU} / \mathrm{cm}^{3}$ ( $26 \%$ de $\mathrm{U}_{3} \mathrm{Si}_{2}$ em volume).

\section{2 - A Evolução do Núcleo do Reator IEA-R1}

É interessante mencionar que o núcleo do reator IEA-R1 nem sempre foi $5 \times 5$ como até então faz-se imaginar. $\mathrm{Na}$ verdade, o primeiro núcleo desse reator, aquele que atingiu a primeira criticalidade em 1957, era 5x6. Esse primeiro núcleo era composto por combustíveis do tipo U-A1. Entretanto, essa configuração não foi efetiva e durou muito pouco, devido a corrosões no combustível (Pitting Corrosion). 
Desde sua primeira configuração, mais de 200 tipos de configurações de núcleos foram realizadas na grade do reator, utilizando diferentes tipos de combustíveis. Em 1968, elementos combustíveis com alto enriquecimento de Urânio (HEU) e placas de U-Al foram importados dos Estados Unidos e utilizados na configuração $5 \times 6$ por vários anos.

$\mathrm{Na}$ mesma época, os elementos de controle foram trocados, aposentando-se os de $\mathrm{B}_{4} \mathrm{C}$ para implementação daqueles do tipo Ag-In-Cd nos elementos combustíveis de controle, fabricados pela CERCA (Acrônimo francês para Company for the Study of Atomic Fuel Creation).

A conversão do núcleo de HEU (High Enriched Uranium) para LEU (Low Enriched Uranium) começou no início dos anos 80, quando 5 elementos combustíveis, compostos de 18 placas de $\mathrm{U}-\mathrm{Al}_{\mathrm{x}}-\mathrm{Al}$ (LEU) fabricadas pela empresa NUKEM Technologies foram introduzidos no núcleo. No mesmo período, iniciram-se pesquisas para o desenvolvimento de elementos combustíveis nacionais que seriam fabricados pelo próprio IPEN.

Devido ao bom desempenho dos protótipos brasileiros fabricados, o primeiro elemento combustível completo tipo LEU foi introduzido no núcleo em 1988 e assim, em média, 2 novos elementos combustíveis LEU foram introduzidos, por ano, no núcleo do reator, incluindo elementos de controle, convertendo gradualmente o núcleo HEU para LEU. Em setembro de 1997, quando o núcleo estava pronto para operar a 5MW, um núcleo completo composto de elementos LEU foi, pela primeira vez, introduzido. 


\section{Introdução aos Aspectos Teóricos Fundamentais}

Antes de se abordar as análises e cálculos que compreendem o presente trabalho, é importante introduzir alguns conceitos que ajudarão na compreensão das análises que virão a seguir. Esses conceitos são fundamentais para se entender e verificar o comportamento dos diversos núcleos estudados para o reator nuclear IEA-R1.

\section{1 - Neutrônica - Aspectos Gerais}

No interior dos reatores nucleares, sejam de pesquisa ou de potência, nêutrons se movimentam em complexas trajetórias devido ao fato de sofrerem diversos tipos de reações com os núcleos dos materiais que compõem os reatores. Por causa de reações como a de fissão nuclear, absorção e espalhamento, por exemplo, nêutrons que estavam originalmente em uma determinada região do espaço e movendo-se em uma dada direção $\widehat{\Omega}^{\prime}$, com energia $E^{\prime}$, passarão a existir, tempo depois, em outra região, possuindo características diferentes daquelas iniciais, ou seja, energia $\mathrm{E}$ e direção $\widehat{\Omega}$.

Nesse caso, diz-se que os nêutrons foram "transportados" de uma região para outra. Esse fenômeno é fundamental para estudar o comportamento dos nêutrons dentro de um reator nuclear, sendo este descrito pela equação do transporte de Boltzmann (Eq. 1).

$$
\begin{aligned}
& \frac{\partial n}{\partial t}+V \widehat{\Omega} \cdot \nabla n+V \Sigma_{t} n \\
&=\int d \widehat{\Omega}^{\prime} \int_{0}^{\infty} d E^{\prime} V^{\prime} \Sigma_{S}\left(\mathrm{E}^{\prime} \rightarrow \mathrm{E}, \widehat{\Omega}^{\prime} \rightarrow \widehat{\Omega}\right) \mathrm{n}\left(\vec{r}, \mathrm{E}^{\prime}, \widehat{\Omega}^{\prime}, t\right)+\mathrm{S}(\vec{r}, \mathrm{E}, \widehat{\Omega}, t)
\end{aligned}
$$


onde,

$n$ é a densidade de nêutrons;

$V$ é a velocidade do nêutron, $V(E)$;

$\widehat{\Omega}$ é o versor direção;

$\Sigma_{t}$ é a seção de choque macroscópica total;

$\vec{r}$ é o vetor posição;

$E$ é a energia dos neutrons após as reações;

$t$ é o tempo;

$\Sigma_{S}$ é a seção de choque macroscópica de espalhamento;

$\widehat{\Omega}^{\prime}$ é o versor direção dos nêutrons antes das colisões;

$E^{\prime}$ é a energia dos nêutrons antes das colisões;

$V^{\prime}$ é a velocidade dos nêutrons antes das reações, $V\left(E^{\prime}\right)$;

$S$ é a fonte externa, se existir;

A resolução da Eq. 1 não é tão trivial quanto derivá-la. Dessa forma, cabe ao pesquisador encontrar a melhor metodologia para resolvê-la. Formas simplificadas dessa equação, como a equação da difusão (Eq. 2), são geralmente utilizadas com bastante êxito, desde que algumas condições sejam satisfeitas.

Mesmo sendo uma aproximação da equação de transporte, a equação da difusão fornece resultados suficientemente precisos e, devido a sua simplicidade, é frequentemente usada em diversos projetos de reatores de pesquisa.

$$
\frac{1}{V} \frac{\partial \Phi}{\partial t}=D \nabla^{2} \Phi-\Sigma_{a} \Phi+v \Sigma_{f} \Phi
$$

onde,

$\Sigma_{a}$ é a seção de choque macroscópica de absorção;

$\mathrm{V}$ é a velocidade dos nêutrons;

$D$ é a o coeficiente de difusão;

$\Phi$ é o fluxo de nêutrons $(\Phi=n V)$; 
$\Sigma_{f}$ é a seção de choque macroscópica de fissão;

$v$ é o número de nêutrons produzidos por fisssão;

A Eq. 2 descreve o caso mono-energético, ou seja, onde todos os nêutrons são tratados de forma igual, possuindo a mesma energia e por consequência, a mesma velocidade. Em reatores de pesquisa, porém, são encontrados vários grupos de nêutrons com energias diferentes. Um argumento que comprova a afirmação passada é a existência obrigatória de um elemento moderador.

A função deste último é diminuir a velocidade (energia) dos nêutrons rápidos que são gerados na fissão. Logo, é direto notar a presença de ao menos dois grupos, os de nêutrons rápidos (gerados na fissão) e os de nêutrons térmicos (desacelerados via moderação). Veja Eq. 3, onde está disposta a equação da difusão para o caso multigrupo.

Em reatores térmicos como o IEA-R1, quem provoca a fissão do U-235 são nêutrons lentos (térmicos). Daí a necessidade do moderador nesses tipos de reatores. No reator IEA-R1, quem faz o papel de moderador é a própria água leve desmineralizada, conforme já mencionado anteriormente.

$$
\frac{1}{V_{g}} \frac{\partial \Phi_{g}}{\partial t}=D_{g} \nabla^{2} \Phi_{g}-\Sigma_{t} \Phi_{g}+\sum_{g^{\prime}=1}^{G} \Sigma_{s}\left(g^{\prime} \rightarrow g\right) \Phi_{g^{\prime}}+\sum_{g^{\prime}=1}^{G}\left(v \Sigma_{f}\right)_{g^{\prime}} \Phi_{g^{\prime}}+S_{g}
$$

Uma vez que os programas de análise neutrônica utilizam diversas metodologias para resolver a equação de transporte de nêutrons, seja por aproximações (eq. da difusão), ou solução direta, é extremamente importante conhecer a fundo a física envolvida nessas equações para melhor compreensão dos resultados obtidos nos cálculos.

A forma para se resolver a equação de transporte utilizada neste trabalho foi aquela implementada nos Softwares MCNP e SERPENT [16] e será discutida mais a frente. 


\section{2 - Termo-Hidráulica de Reatores - Aspectos Gerais}

A análise termo-hidráulica tem por finalidade fornecer valores de temperatura, vazões e fluxos de calor nos diferentes elementos que compõem o núcleo do reator, sendo uma importante ferramenta para verificar se nenhuma variável encontra-se fora do limite de projeto.

Segundo as orientações dispostas no Safety Series - SS.35 da IAEA, para reatores de pesquisa, são avaliados os parâmetros termo-hidráulicos que influenciam no desempenho do reator e estabelecidas as margens para os mesmos [17].

As condições a serem verificadas são:

- Temperatura de mistura do refrigerante inferior a $100{ }^{\circ} \mathrm{C}$;

- Temperatura média na superfície do revestimento inferior a $95{ }^{\circ} \mathrm{C}$;

- Temperatura máxima na superfície do revestimento inferior à temperatura de ONB (Onset of Nucleate Boiling);

- Velocidade de escoamento no canal de resfriamento inferior à velocidade crítica de instabilidade mecânica da placa combustível;

- Fluxo de calor máximo inferior ao fluxo de calor para instabilidade do escoamento (margem FIR);

- Fluxo de calor máximo inferior ao fluxo de calor crítico (margem MDNBR);

\subsection{1 - Critérios de Projeto para Combustíveis MTR - Condições Normais de Operação}

Os critérios e limites de projeto para combustíveis MTR são estabelecidos de forma a não ocorrer mudança geométrica acentuada no elemento combustível e permitir o seu correto funcionamento durante o tempo de permanência no reator. Em regime normal de operação, as temperaturas atingidas no combustível são baixas e muito além das temperaturas de fusão ou de temperaturas que levem a reações químicas entre as partículas dispersas $\left(\mathrm{UAl}_{\mathrm{x}}, \mathrm{U}_{3} \mathrm{O}_{8}, \mathrm{U}_{3} \mathrm{Si}_{2}\right)$ e a matriz [18]. 
Em termos de limites de projeto, a maior preocupação é evitar que as temperaturas na superfície externa do revestimento atinjam valores que provoquem aumento na probabilidade de maior taxa de corrosão no revestimento [19].

Por outro lado, a velocidade crítica do refrigerante é definida como aquela que torna o gradiente de pressão na placa combustível da ordem de sua carga crítica de flambagem.

A essa velocidade de escoamento, as placas tornam-se instáveis e grandes deflexões podem ocorrer (deformações plásticas). Essas deflexões causam um sobreaquecimento das placas combustíveis com possível bloqueio do fluido refrigerante. Um critério de projeto estabelecido é manter a velocidade do refrigerante abaixo de $2 / 3$ da velocidade crítica.

A temperatura na qual tem-se o início da ebulição nucleada (ONB) não é um critério limitante de projeto. Entretanto, esta temperatura define o regime de transferência de calor. Deve-se garantir que o regime de escoamento seja monofásico, por isso a temperatura máxima do revestimento deve se manter abaixo da temperatura de ONB.

Instabilidades no escoamento do fluido refrigerante são indesejáveis em canais aquecidos, pois oscilações no mesmo afetam as características de transferência de calor localmente e podem induzir a um prematuro fluxo crítico de calor. Observa-se que para sistemas de baixa pressão com ebulição sub-resfriada, instabilidades no escoamento do fluido, levando ao fluxo crítico de calor, ocorrem.

O fluxo crítico de calor, que ocorre sob condições de escoamento instável, econtra-se bem abaixo do fluxo crítico de calor para o mesmo canal sob condições de escoamento estável. Assim, nos projetos de elementos combustíveis tipo placa, o fluxo de calor que leva à instabilidade no escoamento do fluido refrigerante pode ser mais limitante do que o fluxo crítico de calor em escoamento estável. 


\section{Metodologia Para Análise Neutrônica e Termo-Hidráulica}

Diversas ferramentas computacionais, como os códigos MCNP, SERPENT e MTRCR-IEAR1, foram utilizadas ao longo deste trabalho, seja para resolver equações complicadas, seja para simular determinados eventos. Um exemplo típico consiste na dinâmica de nêutrons no interior do reator nuclear, ou ainda a transferência de calor em elementos combustíveis para o cálculo das temperaturas e margens termohidráulicas. Devido à importância desses programas de cálculos, esse capítulo é inteiramente dedicado a eles. Dessa forma, uma breve descrição dos principais softwares utilizados é desenvolvida, explicitando suas respectivas metodologias.

\section{1 - O Método Monte Carlo}

Programas como MCNP [11] e SERPENT [12], amplamente utilizados, utilizam a mesma metodologia para resolver a equação de transporte apresentada anteriormente, o método Monte Carlo. Através deste, obtém-se a solução da mencionada equação via simulações de partículas individuais. O comportamento médio dessas partículas é inferido a partir do comportamento médio das partículas simuladas.

O método Monte Carlo é usado para simular processos estatísticos (i.e., interação de partículas nucleares com a matéria) extremamente úteis para abordar problemas complexos que não podem ser abordados por softwares que usam métodos determinísticos.

No método Monte Carlo, os eventos probabilísticos individuais que compreendem um dado processo são simulados sequencialmente. As distribuições de probabilidade que governam esses processos são estatisticamente sorteadas para descrever o fenômeno total. 
Em geral, a simulação é realizada por um computador, pois o número de interações necessárias para adequadamente descrever os fenômenos é bem alto. O processo de sorteio estatístico é baseado na seleção de números aleatórios - assim como o jogar de dados em um jogo de cassino - daí o nome "Monte Carlo".

No transporte de partículas, o método consiste em seguir cada uma delas a partir de uma partícula fonte desde seu nascimento até sua morte (i.e., absorção, escape, etc.). Distribuições probabilísticas são aleatoriamente sorteadas usando bibliotecas de dados de transporte para determinar o resultado em cada passo da vida de uma partícula (veja a Fig. 2 para o caso de um nêutron incidente).

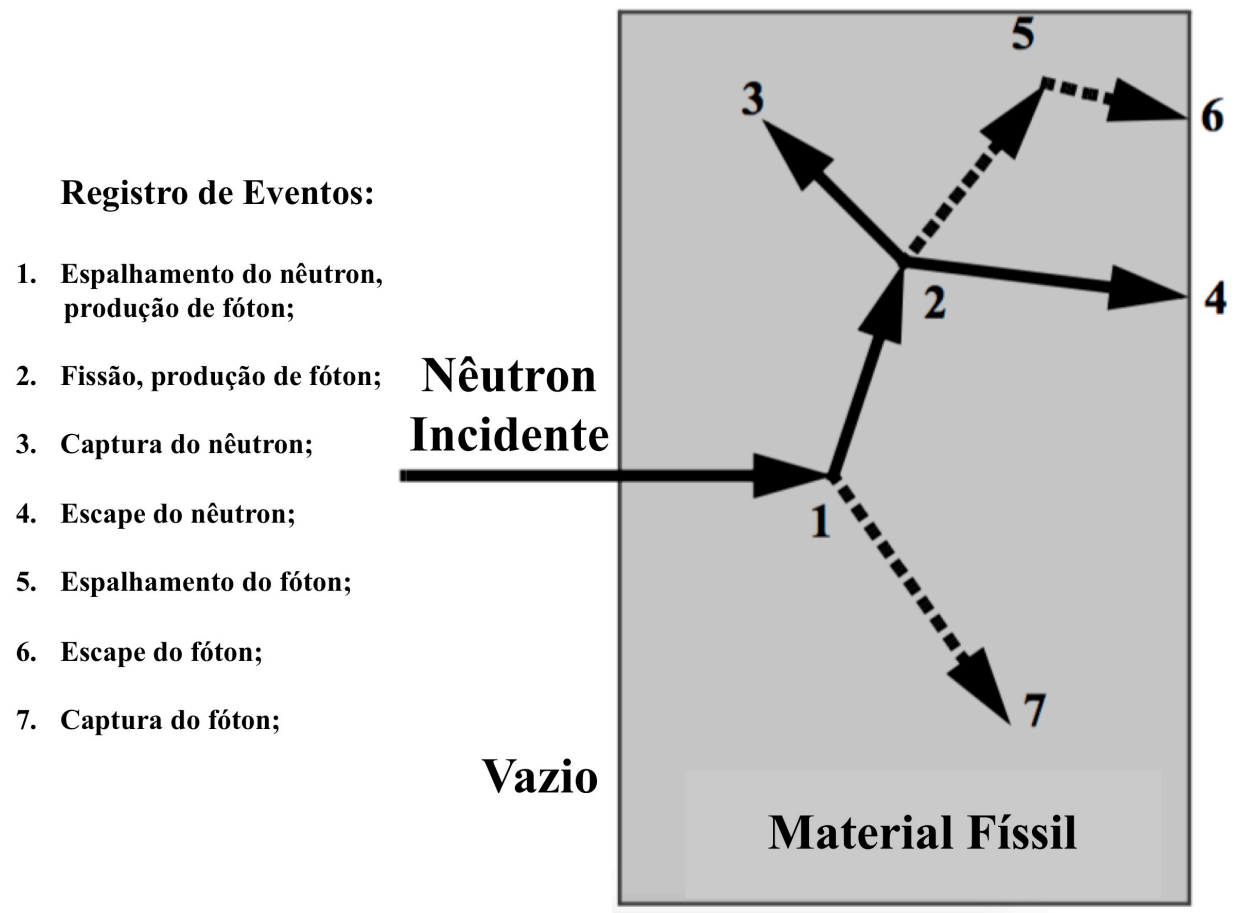

Figura 2 - História aleatória de um nêutron incidente num slab de material físsil.

Números entre 0 e 1 são selecionados aleatoriamente para determinar qual (se alguma) e onde a interação ocorre, baseado nas leis físicas e nas probabilidades (bibliotecas de transporte) que governam os processos e os materiais envolvidos. No exemplo acima, uma colisão do nêutron com o material ocorre no evento 1 . O nêutron é espalhado na direção indicada pela linha contínua, que é escolhida aleatoriamente através da distribuição física de espalhamento. 
Note que um fóton também é produzido e é temporariamente armazenado para análise mais adiante. No evento 2, ocorre a fissão, resultando no fim do nêutron incidente e no nascimento de dois novos e um fóton. Um dos nêutrons e o fóton são armazenados novamente. $\mathrm{O}$ primeiro nêutron de fissão é então capturado no evento 3 e finalizado.

O nêutron que foi armazenado é retomado e, através de um sorteio aleatório, escapa do slab no evento 4. $\mathrm{O}$ fóton produzido na fissão colide no evento 5 e escapa no evento $6 . \mathrm{O}$ fóton restante, gerado no evento 1, é então capturado no evento 7.

Assim, a história desse nêutron incidente, no caso particular acima, está então finalizada (completa). Quanto mais histórias são computadas, mais as distribuições de nêutrons e fótons se tornam mais precisas e bem conhecidas. As quantidades de interesse são computadas, juntamente com as estimativas da precisão estatística (incerteza) dos resultados.

\section{2 - O Modelo Térmico MTRCR-IEAR1}

O modelo Térmico MTRCR-IEAR1 foi desenvolvido no IPEN-CNEN/SP, no ano de 2000, utilizando a plataforma comercial Engineering Equation Solver (EES) [19,20].

A motivação inicial foi a análise termo-hidráulica de canais com diferentes condições de resfriamento e/ou geometrias, não abordada em programas como COBRA/3C [21] e PARET [22]. Posteriormente, foram introduzidas correlações para o cálculo da instabilidade de escoamento, fluxo de calor crítico e a temperatura de ONB (Onset of Nucleate Boiling). O modelo permite fazer estudos paramétricos para diferentes condições de operação muito mais rápidos e com resultados tão precisos quanto os dos referidos programas acima.

Consiste em um conjunto de equações de balanço de fluxo de calor, correlações para o cálculo do coeficiente de transferência de calor, número de Reynolds, número de Prandt e condições de contorno que são resolvidas simultaneamente. $\mathrm{O}$ uso desse modelo computacional permite uma análise termo-hidráulica de reatores de pesquisa com elementos combustíveis MTR (esquema nodal na Fig. 3). 


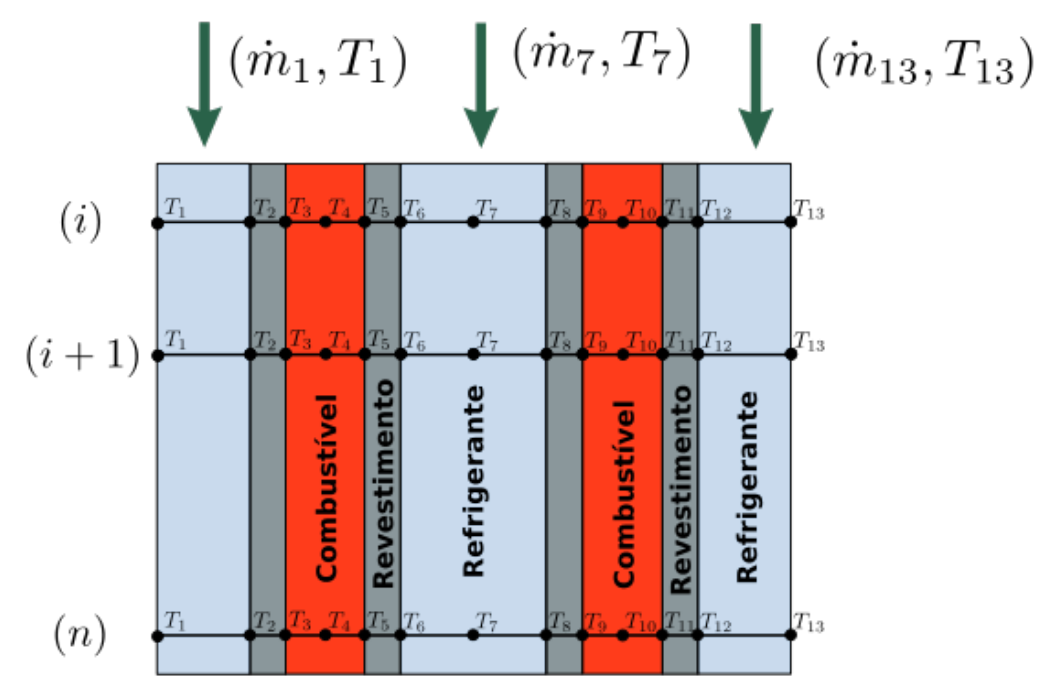

Figura 3 - Esquema simplificado do modelo MTRCR-IEAR1.

Os seguintes parâmetros são calculados ao longo dos canais dos elementos combustíveis:

- Temperatura no centro do combustível;

- Temperatura no revestimento;

- Temperatura no fluido refrigerante;

- Temperatura para início da ebulição nucleada (ONB);

- Fluxo crítico de calor;

- Instabilidade do escoamento;

- Margens de segurança termo-hidráulicas: MDNBR e FIR.

A margem MDNBR (Minimum Departure from Nucleate Boiling Ratio) é calculada como a razão do fluxo de calor crítico pelo fluxo de calor local. A margem FIR (Flux Instability Ratio) é calculada como a razão entre o fluxo de calor para instabilidade de escoamento pelo fluxo de calor local.

Por fim, o modelo ainda utiliza no cálculo as incertezas envolvidas no cálculo termohidráulico, tais como, as incertezas de fabricação do combustível, erro no cálculo de distribuição de densidade de potência, na distribuição de vazão no núcleo e nas margens de segurança para os coeficientes de transferência de calor. 
Todos os cálculos são posteriormente comparados com limites de projetos para a verificação da funcionalidade do reator e aptidão do mesmo a funcionar dentro dos critérios de segurança. 


\section{Novos Núcleos para o Reator IEA-R1: Análise Neutrônica}

Nos capítulos anteriores, procurou-se introduzir alguns conceitos, metodologias e programas que foram utilizados ao longo do estudo para modificações futuras no presente núcleo do reator IEA-R1. O principal objetivo desta tese de doutorado é analisar a possibilidade de se alterar a configuração do reator IEA-R1 $(5 \times 5)$, propiciando uma redução do mesmo, para que se atinjam melhores utilizações do combustível nuclear, usando $4,8 \mathrm{gU} / \mathrm{cm}^{3}$, e que possibilite, no futuro, a utilização desse reator por mais tempo, bem como modificá-lo de acordo com interesses particulares, sendo garantidas as margens de segurança e o bom funcionamento do mesmo.

Mostrar que existe uma ou algumas configurações menores e ao mesmo tempo seguras para o núcleo do reator IEA-R1 é a tese defendida neste trabalho e, ao longo deste capítulo, as análises e estudos referentes a esse assunto são abordados, partindo da análise neutrônica, passando pela análise termo-hidráulica e finalizando com a análise de segurança para o(s) núcleo(s) mais promissores.

\section{1 - Novos Núcleos: Configurações e Nomenclatura}

Nesta seção, os novos e diferentes núcleos estudados são apresentados e modelados do ponto de vista neutrônico através do software MCNP (versão 4C). Foram estudadas novas configurações, desde formatos extremamente compactos, $3 \times 3$, até aqueles com maiores dimensões, como $4 \times 4$. A nomenclatura associada a cada núcleo também é apresentada, a fim de facilitar a associação do nome com a referida configuração.

As Figuras de 4 a 12 ilustram as novas configurações que foram analisadas. As imagens são provenientes do software MCNP4C, do qual o Departamento de Engenharia Nuclear do IPEN possui licença para uso acadêmico. 
O número atribuído a cada configuração, está diretamente relacionado à quantidade de elementos combustíveis (ECP) padrão e de controle (ECC) presentes no núcleo. Por exemplo, se a um núcleo é atribuído o número 5 (configuração 5), quer dizer que naquele núcleo estão presentes 5 elementos combustíveis padrão.

Da mesma forma, se um determinado núcleo receber um “*” após sua numeração, significa que o mesmo possui o mesmo número de elementos combustíveis padrão que algum outro, porém, dispostos em arranjo diferente. Por exemplo, o núcleo de configuração 12 e 12* possuem o mesmo número de elementos combustíveis padrão, entretanto possuem configurações diferentes. As figuras seguintes ilustram os novos núcleos para melhor compreensão. As cores que representam cada componente dos mesmos são iguais àquelas apresentadas na Figura 1.

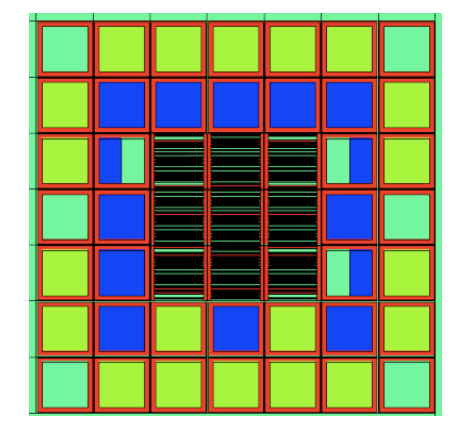

Figura 4 - Configuração 5: 5 (ECP) + 4 (ECC).

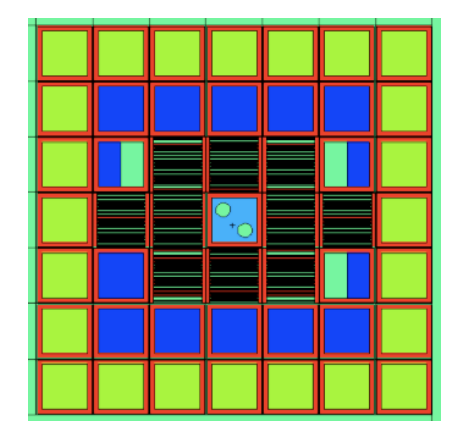

Figura 5 - Configuração 6: 6 (ECP) + 4 (ECC). 


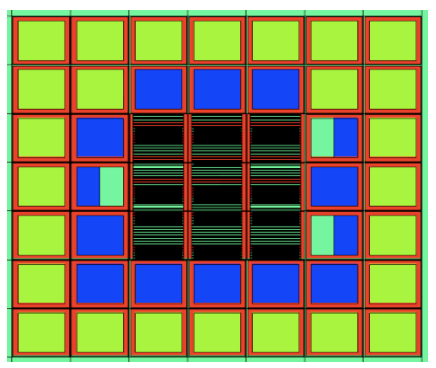

Figura 6 - Configuração 7: 7 (ECP) + 2 (ECC).

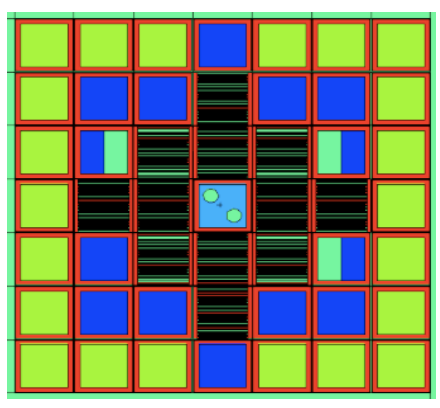

Figura 7 - Configuração 8: 8 (ECP) + 4 (ECC).

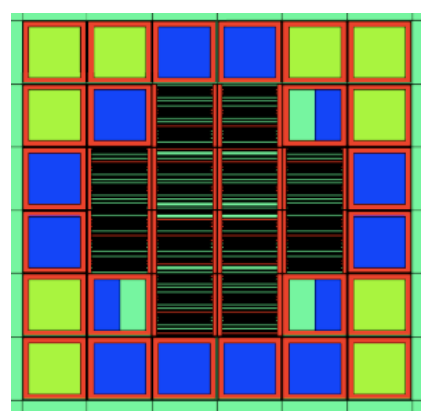

Figura 8 - Configuração $8^{*}: 8$ (ECP) +4 (ECC). 


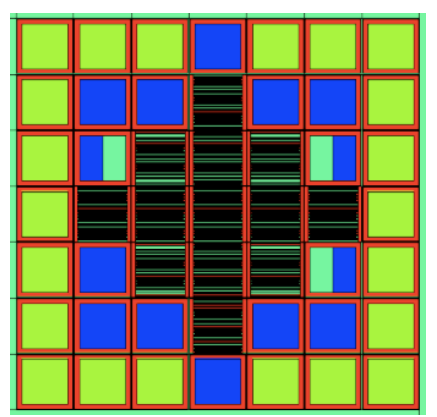

Figura 9 - Configuração 9: 9 (ECP)+ 4 (ECC).

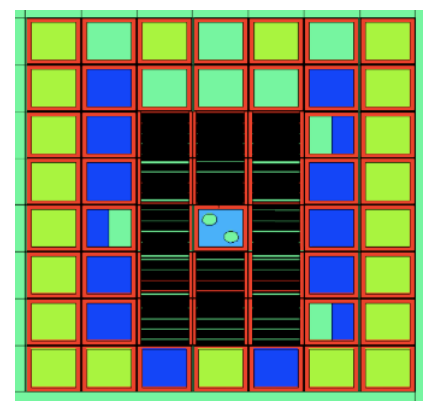

Figura 10 - Configuração 10: 10 (ECP) + 4 (ECC).

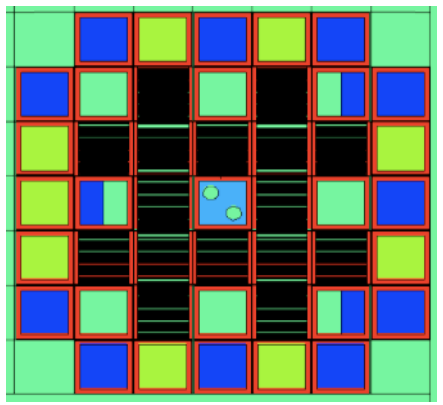

Figura 11 - Configuração 12: 12 (ECP) + 4 (ECC). 


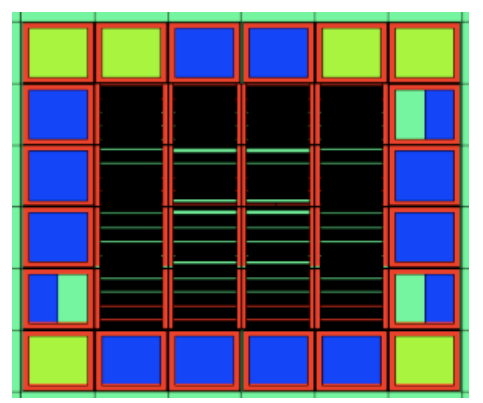

Figura 12 - Configuração 12*: 12 (ECP) + 4 (ECC).

\subsection{1 - Novos Núcleos: Criticalidade, Excesso de Reatividade, Margem de Desligamento (Shutdown Margin) e Valor Total dos Elementos de Controle (Total Control Element Worth)}

Como primeira análise, faz-se necessário avaliar a resposta dos núcleos apresentados anteriormente frente a quesitos neutrônicos fundamentais. As novas configurações foram simuladas para que fosse possível determinar as seguintes grandezas:

- Criticalidade: Determinação do fator de multiplicação $\left(k_{e f f}\right)$

- Excesso de reatividade $\left(\rho_{\text {ex }}\right)$;

- Margem de desligamento, Shutdown Margin $\left(\rho_{S M}\right)$;

- Valor total dos elementos de controle, Total Control Element Worth $(\Delta \rho=$ $\left.\rho_{e x}+\rho_{S M}\right)$.

A condição fundamental para que se ocorra, no interior do núcleo de um reator nuclear, uma reação em cadeia autossustentada é que, em média, cada nêutron produza um outro para substituí-lo, a despeito das possíveis absorções pelo moderador, pelo urânio e das perdas por escape do sistema.

Esses nêutrons apresentam grandes variedades de possíveis fatos no decorrer de sua história, desde a formação até sua eventual perda. Esse tipo de reação em cadeia depende de um balanço favorável entre quatro processos competitivos: 
- A Fissão de núcleos de urânio, com o número de nêutrons emitidos sendo maior que o número de nêutrons capturados;

- Captura de nêutrons pelo urânio sem ocorrência de fissão;

- Captura de nêutrons por outros materiais, sem que ocorra fissão;

- Escape de nêutrons do núcleo do reator.

Assim, para que ocorra a reação em cadeia autossustentada, é necessário que o excesso de nêutrons devido ao primeiro mecanismo seja maior do que as perdas nos demais. $\mathrm{O}$ balanço de nêutrons em um reator nuclear térmico pode ser descrito através de um ciclo que mostra a história dos nêutrons (Fig. 13).

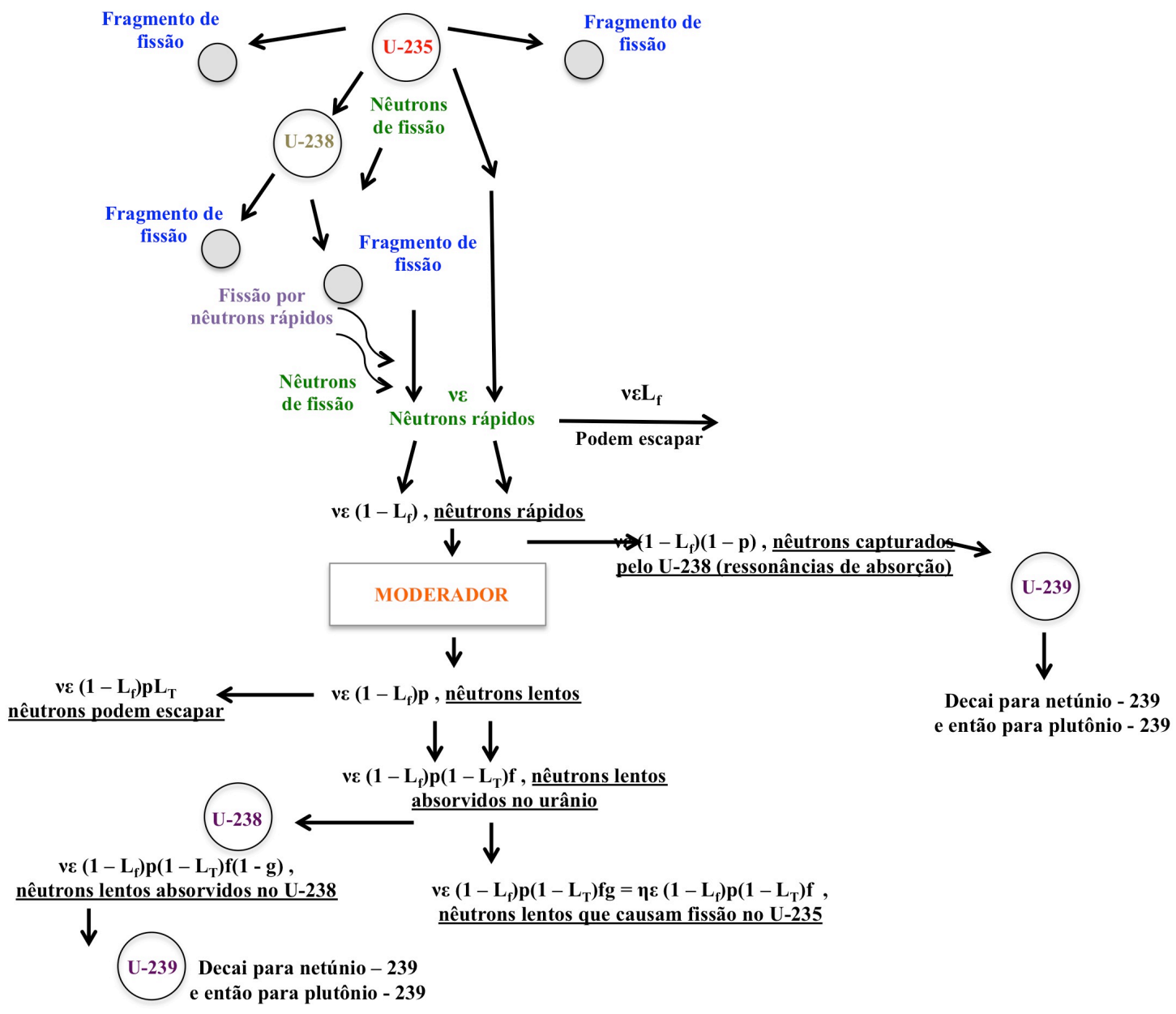

Figura 13 - Representação esquemática de uma reação em cadeia auto-sustentada e baseada na fissão de núcleos de urânio por nêutrons térmicos. 
A história começa com a fissão de um núcleo de U-235 por um nêutron térmico. Através desse processo são produzidos $v$ nêutrons rápidos. Entretanto, a energia cinética média desses nêutrons se situa acima do limiar de fissão do U-238, mas alguns deles podem causar a fissão dos mesmos.

A probabilidade para que essas fissões adicionais ocorram depende de como os nêutrons de fissão colidem com os núcleos de U-238, antes de colidir com os núcleos do moderador (material responsável por reduzir a energia do nêutron até regiões térmicas, ou seja, regiões em que provocam fissões no U-235). Uma fração pequena dos nêutrons que colidem com os núcleos de U-238 pode causar fissões e assim, dado um número inicial de nêutrons resultantes da fissão térmica do U-235, alguns nêutrons adicionais são resultantes da fissão rápida de núcleos de U-238.

$\mathrm{O}$ número total de nêutrons rápidos obtidos a partir da fissão passa então de $v$ para $v \varepsilon$, onde $\varepsilon$ pode ser igual ou maior que a unidade. Essa grandeza $\varepsilon$ é chamada fator de fissão rápida. Os $v \varepsilon$ nêutrons percorrem o reator nuclear. Grande parte deles é moderada, mas uma fração $L_{f}$ escapa antes de ser moderada a energias térmicas, de forma que $v \varepsilon L_{f}$ nêutrons são perdidos.

Os nêutrons restantes, $v \varepsilon\left(1-L_{f}\right)$, são moderados por meio de colisões com núcleos do moderador (no caso do reator IEA-R1, água leve desmineralizada). Durante o processo de moderação, alguns deles podem ser capturados pelo U-238, formando o núcleo composto U-239, que decai para o $\mathrm{Np}-239$ e depois para o Pu-239. Dos $v \varepsilon\left(1-L_{f}\right)$ nêutrons que iniciaram o processo de moderação, somente uma fração $p$ é que escapa de fato da captura, ou seja, $v \varepsilon\left(1-L_{f}\right) p$ nêutrons, enquanto $v \varepsilon\left(1-L_{f}\right)(1-p)$ nêutrons são capturados e vão formar o Pu-239. A grandeza $p$ é chamada de probabilidade de escape da ressonância.

Os demais nêutrons que escapam das ressonâncias de absorção são moderados a energias cinéticas térmicas, onde tanto a fissão quanto a captura radiativa ocorrem. Alguns desses nêutrons se difundem sem serem capturados e eventualmente escapam do sistema. Se a fração que escapa do sistema é $L_{T}$, o número de nêutrons térmicos por fissão do U-235 que escapa é dado por $v \varepsilon\left(1-L_{f}\right) p L_{T}$. 
Os nêutrons restantes perfazem $v \varepsilon\left(1-L_{f}\right) p\left(1-L_{T}\right)$, dos quais uma fração $f$ é absorvida pelo urânio e uma fração $(1-f)$ é absorvida por outros materiais, sendo então perdidos. O número de nêutrons então disponível para perpetuar a reação em cadeia é $v \varepsilon\left(1-L_{f}\right) p\left(1-L_{T}\right) f$. A grandeza $f$ é chamada de utilização térmica.

Nem todos os nêutrons absorvidos pelo urânio causam fissões no U-235. Alguns dos nêutrons são absorvidos pelo U-238 para formar o núcleo composto U-239 e, em sequência, Pu-239, enquanto outros são absorvidos pelo U-235 para formar o núcleo composto U-236. A fração dos nêutrons térmicos absorvidos pelo urânio e que causa fissão é exatamente a razão entre a seção de choque de fissão e a seção de choque de absorção (resultante da soma das seções de choque de fissão e de captura radiativa) para o urânio, ou seja, $\sigma_{f}(U) / \sigma_{a}(U)$ (representada pela letra "g” na Fig. 13).

Assim, o número de fissões de segunda geração no U-235, por fissão do U-235 causada por um nêutron de primeira geração, é o então chamado fator de multiplicação, sendo indicado por $k$.

$$
k=v \varepsilon\left(1-L_{f}\right) p\left(1-L_{T}\right) f \sigma_{f}(U) / \sigma_{a}(U)
$$

O produto $v \sigma_{f}(U) / \sigma_{a}(U)$ representa o número de nêutrons produzidos por fissão por nêutron térmico absorvido no urânio, sendo designado por $\eta$. O fator de multiplicação pode ser então escrito como

$$
k=\eta \varepsilon p f\left(1-L_{f}\right)\left(1-L_{T}\right)
$$

A grandeza $k$, dada pela expressão acima (fórmula dos seis fatores), é em geral denominada fator de multiplicação efetivo. Os seguintes valores de $k$ são possíveis:

- $\quad k>0$, sistema supercrítico;

- $\quad k<0$, sistema subcrítico (desligado);

- $\quad k=1$, sistema crítico. Reação auto-sustentada (e controlada, no caso de reatores nucleares). 
O software MCNP calcula o fator de multiplicação efetivo acompanhando a história de vários nêutrons (conforme já explicado) e, através do método Monte Carlo, determina o valor médio global dessa grandeza, juntamente com o erro estatístico associado. Determinou-se, através de simulações computacionais, o fator de multiplicação efetivo $\left(k_{e f f}\right)$ para os candidatos a novos núcleos, considerando as seguintes premissas (Tabela $1)$ :

- Calculo de $k_{\text {eff }}$ para os núcleos limpos, ou seja, sem considerar possíveis impurezas nos materiais que os compõem;

- Cálculo de $k_{e f f}$ considerando todas as barras de controle fora da região ativa dos núcleos;

- Cálculo de $k_{\text {eff }}$ considerando todas as barras de controle totalmente inseridas na região ativa dos núcleos.

Tabela 1 - Cálculo do $k_{e f f}$ e Excesso de Reatividade $\left(\rho_{e x}\right)$ para os novos núcleos do reator IEA-R1.

\begin{tabular}{|c|c|c|c|c|c|c|c|c|}
\hline \multirow[b]{2}{*}{ Núcleo } & \multicolumn{4}{|c|}{ Todas as Barras de Controle Fora } & \multicolumn{4}{|c|}{ Todas as Barras de Controle Dentro } \\
\hline & $k_{e f f}$ & MCNP & $\mathrm{PCM}$ & $\rho_{e x}$ & $k_{e f f}$ & MCNP & $\mathrm{PCM}$ & $\rho_{e x}$ \\
\hline 5 & 1,00312 & 0,00030 & 29,81 & 311,03 & 0,79186 & 0,00031 & 49,44 & $-26284,95$ \\
\hline 6 & 1,01671 & 0,00033 & 31,92 & 1643,54 & 0,79282 & 0,00031 & 49,32 & $-26132,04$ \\
\hline 7 & 1,03063 & 0,00032 & 30,13 & 2971,97 & 0,88447 & 0,00029 & 37,07 & $-13062,06$ \\
\hline 8 & 1,06388 & 0,00031 & 27,39 & 6004,44 & 0,84794 & 0,00031 & 43,12 & $-17932,87$ \\
\hline $8^{*}$ & 1,08691 & 0,00031 & 26,24 & 7996,06 & 0,84976 & 0,00029 & 40,16 & $-17680,29$ \\
\hline 9 & 1,09327 & 0,00034 & 28,45 & 8531,29 & 0,89129 & 0,00030 & 37,76 & $-12196,93$ \\
\hline 10 & 1,09849 & 0,00029 & 24,03 & 8965,94 & 0,88789 & 0,00031 & 39,32 & $-12626,56$ \\
\hline 12 & 1,11973 & 0,00034 & 27,12 & 10692,76 & 0,91097 & 0,00032 & 38,56 & $-9773,10$ \\
\hline $12 *$ & 1,15367 & 0,00030 & 22,54 & 13320,10 & 0,95053 & 0,00031 & 34,31 & $-5204,46$ \\
\hline
\end{tabular}

Duas outras grandezas importantes são a margens de desligamento (shutdown margin) e o valor total dos elementos de controle (total control elemento worth). Essas grandezas devem ser mensuradas, a fim de garantir que, independente do estágio de operação do reator, sempre haja reatividade negativa que possa ser inserida nos núcleos e provocar o completo desligamento dos mesmos, caso necessário. 
Há basicamente duas formas distintas de se definir a margem de desligamento (shutdown margin). Pode ser abordada de forma clássica como a quantidade de reatividade extra necessária para elevar o estado subcrítico (com todas as barras de controle inseridas) até ao estado crítico em um dado reator nuclear $\left(1-k_{e f f}\right)$, ou então, do ponto de vista de segurança, pode ser entendida como a quantidade instantânea de reatividade na qual o reator está subcrítico ou deveria estar subcrítico, assumindo todas as barras de controle completamente inseridas no núcleo, considerando somente uma única barra, a de mais alto valor (critério da barra presa), que é assumida completamente fora da região ativa.

Em outras palavras, a diferença entre as duas definições consiste no fato de que em uma delas, a segunda, uma barra de controle é mantida fora da região ativa do núcleo, enquanto as demais estão completamente inseridas. Assim como a primeira, a segunda abordagem é extremamente importante do ponto de vista de segurança e deve ser também levada em conta, pois o sistema de segurança composto pelas barras de controle deve ser capaz de desligar o núcleo com uma boa margem de segurança mesmo se uma delas, por algum motivo, ficar presa fora da região ativa em casos de desligamento ou emergência. O valor total dos elementos de controle, por sua vez, é definida como a soma da margem de desligamento e o excesso de reatividade do núcleo, considerando todas as barras completamente fora da região ativa.

A Fig. 14 ilustra bem a relação entre essas grandezas (cálculos na Tabela 2). Para o cálculo da margem de desligamento do ponto de vista de segurança, considerou-se que todas as barras inseriram, em média, a mesma quantidade de reatividade negativa nos núcleos.

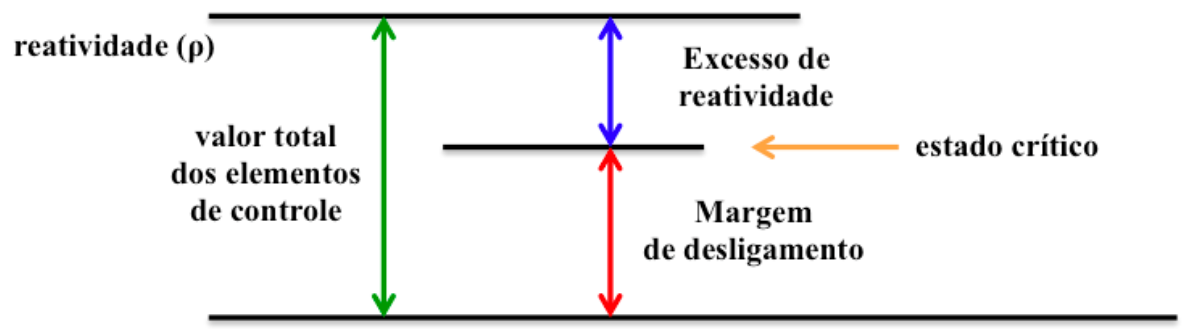

Figura 14 - Relação entre a margem de desligamento, valor total dos elementos de controle e excesso de reatividade. 
Tabela 2 - Cálculo da margem de desligamento $\left(\rho_{S M}\right)$ e do valor total dos elementos de controle $(\Delta \rho)$ para os novos núcleos do reator IEA-R1.

\begin{tabular}{|c|c|c|c|c|c|c|c|c|}
\hline \multirow[b]{2}{*}{ Núcleo } & \multicolumn{4}{|c|}{$\rho_{S M}=\left(1-k_{e f f}\right)$} & \multicolumn{4}{|c|}{$\Delta \rho=\rho_{S M}+\rho_{e x}$} \\
\hline & Clássica & $\mathrm{PCM}$ & Segurança & $\mathrm{PCM}$ & Clássica & $\mathrm{PCM}$ & Segurança & PCM \\
\hline 5 & 0,20814 & 26285 & 0,15611 & 19714 & 0,21126 & 26596 & 0,15923 & 20025 \\
\hline 6 & 0,20718 & 26132 & 0,15539 & 19599 & 0,22389 & 27776 & 0,17210 & 21243 \\
\hline 7 & 0,11553 & 13062 & 0,08665 & 6531 & 0,14616 & 16034 & 0,11728 & 9503 \\
\hline 8 & 0,15206 & 17933 & 0,11405 & 13450 & 0,21594 & 23937 & 0,17793 & 19454 \\
\hline $8^{*}$ & 0,15024 & 17680 & 0,11268 & 13260 & 0,23715 & 25676 & 0,19959 & 21256 \\
\hline 9 & 0,10871 & 12197 & 0,08153 & 9148 & 0,20198 & 20728 & 0,17480 & 17679 \\
\hline 10 & 0,11211 & 12627 & 0,08408 & 9470 & 0,21060 & 21593 & 0,18257 & 18436 \\
\hline 12 & 0,08903 & 9773 & 0,06677 & 7330 & 0,20876 & 20466 & 0,18650 & 18023 \\
\hline $12 *$ & 0,04947 & 5204 & 0,03710 & 3903 & 0,20314 & 18525 & 0,19077 & 17223 \\
\hline
\end{tabular}

\subsection{2 - Novos Núcleos: Densidade de Potência e Determinação dos Fatores de Pico para Subsequente Análise Termo-Hidráulica}

A geração de calor em reatores nucleares, bem como sua remoção do combustível nuclear e de outros materiais estruturais são de extrema importância, uma vez que os aspectos térmicos limitam a geração de energia no caso de uma central nuclear e também ditam regras de funcionamento para reatores cujo objetivo não seja a produção de energia (reatores de pesquisa), como no caso do reator IEA-R1.

Nenhum projeto pode ser implementado se não passar por uma rigorosa análise termohidráulica. A título de exemplo, se a temperatura no revestimento do combustível ultrapassar o seu ponto de fusão, poderá haver liberação de produtos de fissão na atmosfera (como os isótopos radioativos do Césio e do Iodo), afetando a saúde dos trabalhadores e também da população nas vizinhanças do prédio do reator. Dessa maneira, o reator deve operar de tal forma que as temperaturas no núcleo não ultrapassem os limites de segurança, limites estes que serão abordados e discutidos em seção específica à frente. 
Para que se possa garantir o bom funcionamento do reator do ponto de vista termohidráulico, deve-se conhecer os perfis de temperaturas no núcleo e, para que isso seja possível, é necessário conhecer a fonte térmica de energia ou densidade de potência $\left(q^{\prime \prime \prime}\right)$ em cada região de interesse. A densidade de potência nada mais é do que o calor gerado em cada ponto por unidade de volume e por unidade de tempo. Uma vez conhecida a distribuição dessa grandeza no núcleo do reator, pode-se determinar se o projeto atende ou não às especificações técnicas termo-hidráulicas e de segurança.

Antes de explicar como o calor é gerado em um reator nuclear, alguns conceitos básicos devem ser abordados, tais como:

- O Fluxo de nêutrons;

- A Seção de choque;

- A Taxa de reação.

\subsubsection{1 - O Fluxo de Nêutrons}

O número de partículas que cruzam uma área unitária por unidade de tempo em uma dada direção recebe o nome de corrente e, no caso em questão, onde as partículas são os nêutrons, corrente de nêutrons. Dentro do núcleo de um reator nuclear esses nêutrons viajam em várias direções.

Se $n$ é a densidade de nêutrons (nêutrons $/ \mathrm{cm}^{3}$ ) e $V$ a velocidade dos mesmos, o produto $n V$ é o número de nêutrons cruzando uma área unitária vindos de várias direções por unidade de tempo e é chamado fluxo de nêutrons $\phi$ (nêutrons/área/tempo). Note que o nome "fluxo de nêutrons" aplicado no contexto da engenharia nuclear é enganoso. O fluxo $\phi$ não é o mesmo que aquele encontrado na teoria do eletromagnetismo e na transferência de calor, onde nestes últimos, os fluxos são grandezas vetoriais e o fluxo de nêutrons, escalar.

O fluxo em um dado ponto do núcleo do reator leva em conta os nêutrons advindos de todas as direções e, dessa forma, a taxa com que os nêutrons reagem com os núcleos atômicos é proporcional ao mesmo. 
Como o fluxo depende da velocidade $(V)$ e esta última depende da energia dos nêutrons $(E)$, o fluxo também será função da energia $(\phi(E))$.

Geralmente o fluxo de nêutrons é determinado para determinadas faixas de energia, como a térmica $(E<1 \mathrm{eV})$ e a rápida $\left(E>10^{5} \mathrm{eV}\right)$. Essas faixas de energia devem ser especificadas no input dos softwares de cálculos neutrônicos (MCNP/SERPENT no presente caso).

No núcleo do reator, o fluxo de nêutrons varia de um valor máximo (geralmente no centro) para valores mínimos (próximo às bordas). No caso do reator IEA-R1, que é um reator térmico heterogêneo (separação entre o combustível e o moderador), os nêutrons são gerados no combustível e suas energias são baixadas até a região térmica no moderador, sendo natural haver um "pico" de fluxo rápido no combustível (onde nascem os nêutrons de fissão, ou seja, rápidos) e um "pico" de fluxo térmico no moderador (local onde os nêutrons terão suas energias diminuídas).

Determinar a distribuição de fluxo no núcleo nem sempre é um processo simples, basta haver uma geometria assimétrica, um arranjo heterogêneo ou diversos materiais presentes na análise para torná-la complicada, sendo necessário a utilização de ferramentas computacionais.

Para o cálculo da densidade de potência ao longo do núcleo, deve-se conhecer a distribuição de fluxo que, no presente estudo, foi calculada via método Monte Carlo e dentro do próprio MCNP, convertido em densidade de potência.

\subsubsection{2 - A Seção de Choque}

Para se compreender esse conceito, geralmente utiliza-se a analogia geométrica. Entretanto, é importante saber de antemão que a seção de choque é uma grandeza cujo cálculo na maioria das vezes não é simples, valendo-se da teoria quântica para sua determinação. 
Voltando à analogia clássica-geométrica, imagine que várias bolinhas de tênis fossem jogadas contra uma grande janela de vidro, que possui em seu centro um disco de área $A_{\text {Disco }}$. O número de bolinhas que irão colidir com o disco é proporcional a essa área (quanto maior o disco, maior a chance de colisão). A fração de bolinhas colidindo com o disco, ou a probabilidade de colisão, é dada pela razão $A_{\text {Disco }} / A_{\text {Janela }}$. Se ao invés de um disco houvesse uma esfera no centro da janela, ou seja, uma geométrica tridimensional, a área envolvida seria a da seção transversal da esfera ( $\left.4 \pi R_{E s f e r a}^{2}\right)$.

Em reações nucleares, quem faz o papel das bolinhas de tênis são os nêutrons e o papel da esfera, os núcleos atômicos. Assim, a seção de choque microscópica nada mais é do que uma área transversal que o nêutron enxerga quando diante de um núcleo atômico (usualmente dada em barn, onde 1 barn $=10^{-24} \mathrm{~cm}^{2}$ ). Essa área fictícia depende essencialmente do núcleo atômico em questão, da energia do nêutron e do tipo de reação. Do ponto de vista clássico, a seção de choque microscópica $\sigma$, seria a área transversal de cada núcleo atômico vista pelo nêutron incidente $\left(R_{\text {nuclear }} \sim 10^{-12} \mathrm{~cm}\right.$, portanto, $A_{\text {nuclear }} \propto R_{\text {nuclear }}^{2}=10^{-24} \mathrm{~cm}^{2}$, daí a necessidade de usar o barn como unidade de área).

Apesar de simples e intuitiva, a ideia de área transversal pode ser enganosa se a seção de choque for muito maior ou muito menor que a área transversal nuclear (devido a efeitos de ressonância causados pela natureza quântica do nêutron e do núcleo). A seção de choque de absorção para nêutrons lentos no Xe-135 é milhões de vezes maior que a área transversal geométrica do núcleo em questão, por exemplo.

\subsubsection{3 - A Taxa de Reação}

Para se determinar a distribuição de nêutrons no núcleo de um reator, deve-se conhecer o movimento dos mesmos dentro do núcleo (fluxos) e também a interação dos nêutrons com os núcleos atômicos (seção de choque), especialmente com os núcleos do combustível. A densidade de nêutrons é extremamente importante, pois permite-se calcular a taxa com que as reações nucleares estão ocorrendo em determinado ponto do núcleo do reator. 
Lembrando que a seção de choque macroscópica, definida como $\Sigma=N \sigma$ ( $N$ sendo a densidade de núcleos em um dado material), é a probabilidade por unidade de comprimento de que um nêutron sofra uma reação e que $V$ é a distância percorrida por unidade de tempo, então o produto $V \Sigma$ é a frequência com que determinada reação ocorre.

Essa quantidade é frequentemente chamada de frequência de colisão dos nêutrons em uma amostra (seu recíproco é o tempo médio entre as colisões).

Assim, pode-se definir a taxa de uma reação por unidade de volume $(\mathrm{R})$ em qualquer ponto, multiplicando-se a densidade de nêutrons n pela frequência de colisão

$$
R=n V \Sigma=\Sigma \underbrace{n V}=\Sigma \phi
$$

Essa taxa é dada para nêutrons mono-energéticos, tendo em vista que tanto o fluxo quanto a seção de choque dependem da energia.

Uma vez conhecidos os conceitos brevemente discutidos acima, uma expressão para o calor gerado no combustível nuclear pode ser encontrada. É claro que o calor também pode ser gerado devido a outros tipos de reações e em outras regiões do reator, mas para os presentes propósitos, só será considerado aquele advindo de reações nucleares de fissão. Assim, o número de núcleos por unidade de volume só levará em conta os núcleos que podem sofrer fissão, ou seja, os núcleos do combustível físsionável. O índice "ff" (fissionable fuel) é empregado em $N_{f f}$ para se referir ao combustível fissionável. A seção de choque também será aquela referente à fissão nuclear, ou seja, com índice "f" (fission), $\sigma_{f}$. Dessa forma, a equação (6) se tornará:

$$
R=n V \Sigma_{f}=\mathrm{N}_{f f} \sigma_{f} \underbrace{\mathrm{nV}}=\Sigma_{f} \phi
$$

Se cada fissão liberar uma quantidade $G_{f}$ de energia, o produto $G_{f} R$ será a energia total liberada devido às reações de fissão por unidade de volume por unidade de tempo e é chamada de fonte térmica volumétrica ou densidade de potência, $q^{\prime \prime \prime}$ : 


$$
q^{\prime \prime \prime}=\mathrm{G}_{f} \mathrm{R}=\mathrm{G}_{f} \mathrm{~N}_{f f} \sigma_{f} \phi
$$

A partir de agora, sempre que houver referência ao termo densidade de potência, é a equação (8) que se deve ter em mente. Essa equação é válida para um caso bem particular e, se quisermos generalizá-la, basta integrá-la em todas as energias e levar em conta todos os materiais e energias liberadas que, matematicamente, está disposto na equação (9).

$$
q^{\prime \prime \prime}(\vec{r})=\sum_{i} \mathrm{G}^{i} \mathrm{~N}^{i}(\vec{r}) \int \sigma_{f}^{i} \phi(\vec{r}, E) d E
$$

Assim, os termos da equação (9) devem ser computados para se determinar a densidade de potência em todos os pontos de interesse. O fluxo neutrônico é determinado através do software MCNP, as seções de choque, disponíveis para alguns casos particulares, são processadas pelo software NJOY [24] e usadas também pelo MCNP e SERPENT. Os dados relativos aos materiais, como a densidade atômica, estão disponíveis em ambos softwares citados e, quando não, podem ser encontrados em sites específicos na internet que fornecem bibliotecas de seções de choque. A Fig. 15 ilustra a densidade de potência média nos novos núcleos estudados para o reator IEA-R1. Para cada configuração (vide nomenclatura na seção 6.1), encontram-se dispostas as respectivas densidades de potência, assim como o número de placas combustíveis presente em cada arranjo.

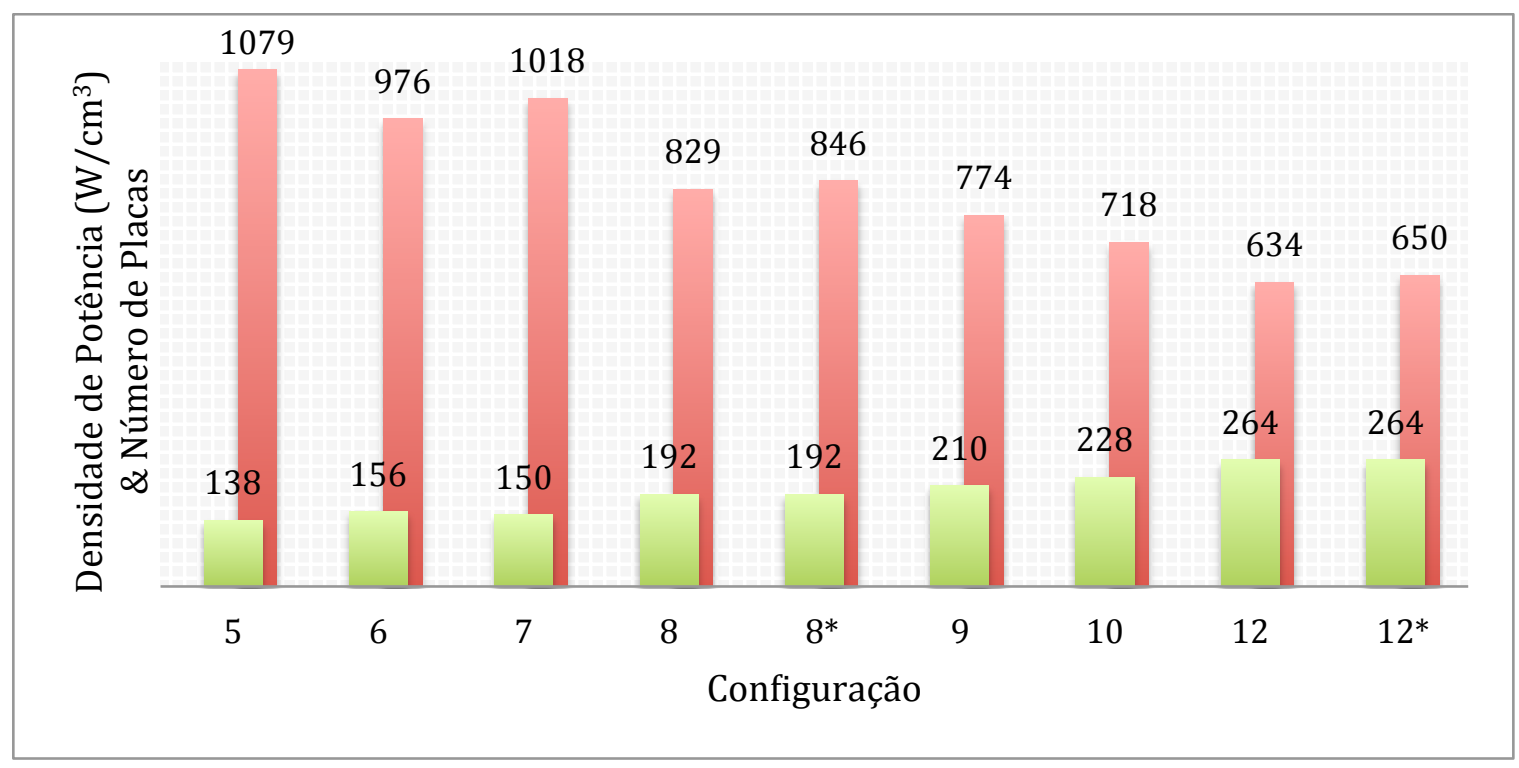

Figura 15 - Densidade de potência média no núcleo por configuração. 
Para cada nova configuração, determinou-se a placa combustível mais quente, ou seja, aquela com maior valor para a densidade de potencia média, levantando-se o perfil axial para a mesma. Essa informação é dado de entrada para cálculos termo-hidráulicos subsequentes. Os valores para as densidades de potência nas placas mais quentes, calculados via MCNP, estão dispostos na Tabela 3.

Tabela 3 - Densidade de potência média na placa combustível mais quente em cada uma das novas configurações.

\begin{tabular}{|c||c|}
\hline Núcleo & Densidade de Potência Média $\left[\mathrm{W} / \mathrm{cm}^{3}\right]$ \\
\hline 5 & 1448 \\
6 & 1438 \\
7 & 1459 \\
8 & 1281 \\
$8^{*}$ & 1508 \\
9 & 1114 \\
10 & 1179 \\
12 & 1057 \\
$12^{*}$ & 1259 \\
\hline
\end{tabular}

Com as informações previamente discutidas, é possível então determinar os fatores de pico locais para cada uma das placas mais quentes de cada configuração. Note que o cálculo dos fatores de pico somente é necessário, a princípio, para as placas mais quentes, pois, garantindo-se o bom funcionamento das mesmas do ponto de vista térmico, as demais, que geram menos calor, necessariamente também atenderão às margens e limites termo-hidráulicos. Entende-se, para fins do presente trabalho que, fator de pico local, grandeza adimensional, é definido como $q^{\prime \prime \prime}(\vec{r}) / q^{\prime \prime \prime}$ médio no núcleo, de forma que $q^{\prime \prime \prime}(\vec{r})$ se refere ao perfil axial de densidade de potência na placa mais quente de cada núcleo e $q^{\prime \prime \prime}$ médio no núcleo, a densidade de potência média em cada núcleo (Fig.15). Assim, com essa definição de fator de pico local, cria-se uma métrica para identificar o quanto o perfil axial de densidade de potência na placa mais quente de uma dada configuração difere do valor médio dessa grandeza encontrado no núcleo todo. 
A Fig. 16 ilustra o perfil axial do fator de pico local na placa mais quente de cada configuração.

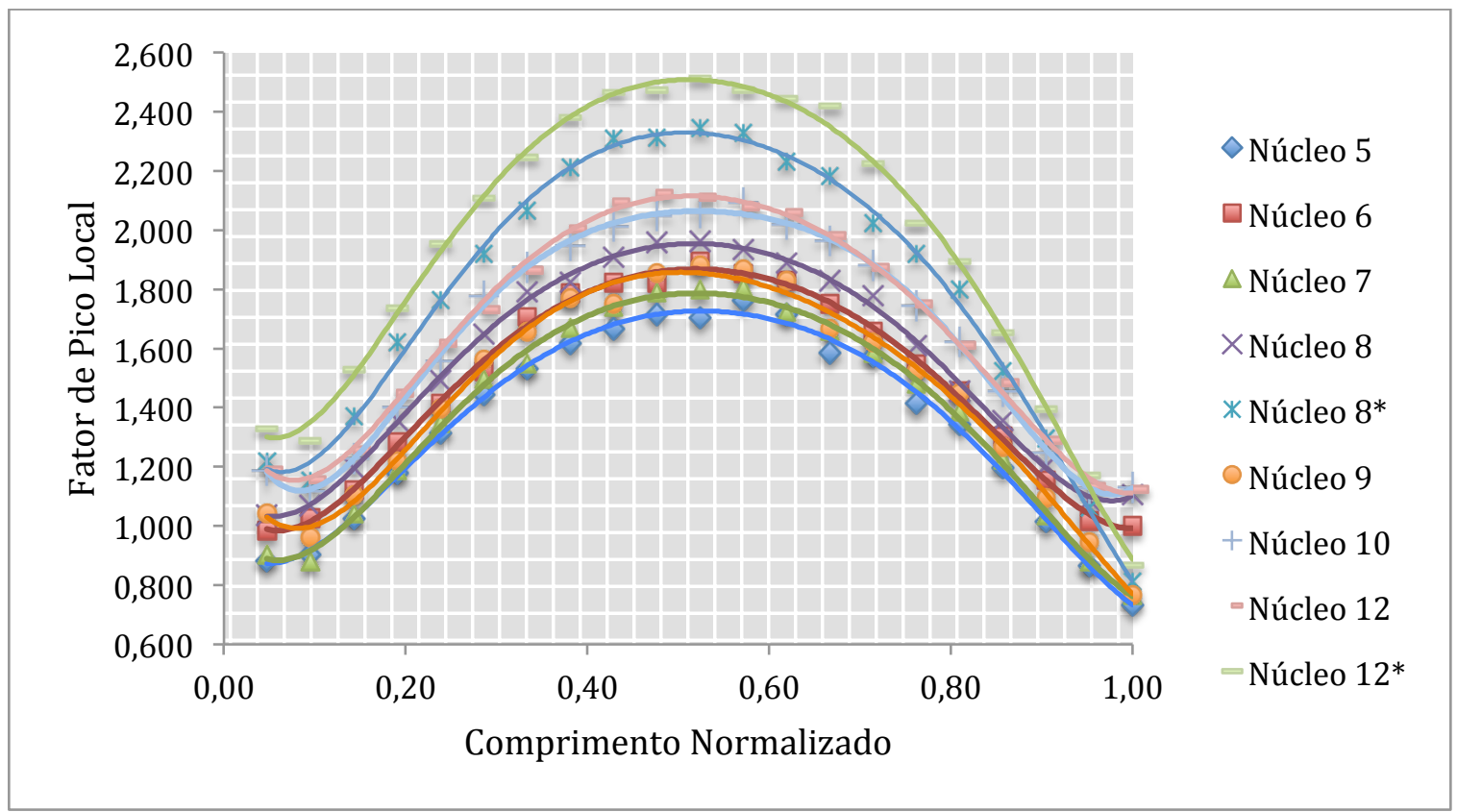

Figura 15 - Fator de pico local vs. Comprimento normalizado (placa mais quente).

A partir dos dados e informações dispostos na presente seção e também anteriormente, torna-se possível examinar o funcionamento dos novos núcleos propostos a partir de outros dois pontos de vista: a análise termo-hidráulica e a análise de segurança. Essas duas últimas, às vezes, confundem-se, dependendo do contexto em que são empregadas.

Entretanto, ambas terão aspectos estudados e discutidos neste trabalho e serão abordadas com mais detalhes nas seções seguintes. 


\section{Novos Núcleos para o Reator IEA-R1: Análise Termo-Hidráulica}

A energia liberada na fissão dos átomos de Urânio (U-235) por nêutrons térmicos aparece como energia cinética dos produtos de fissão e eventualmente como calor gerado nos elementos combustíveis. Esse calor deve ser removido do núcleo do reator e no caso de reatores de potência, usado para gerar energia elétrica.

O calor é transportado via condução térmica por todo o elemento combustível, passando do combustível nuclear para o revestimento e, a posteriori, via convecção forçada, para o fluido refrigerante, seja como calor sensível (aumento da temperatura do fluido), ou como calor latente (com mudança de fase, líquido para vapor, por exemplo), onde, por fim, o fluxo de massa desse fluido leva a energia térmica para fora do núcleo do reator.

A Fig. 17 ilustra o caminho percorrido pela energia térmica até ser removida pelo refrigerante e a Fig. 18, o esquema de resfriamento do núcleo de um reator genérico tipo placa (combustíveis com geometria retangular, assim como os do reator IEA-R1, mas lembrando que no caso específico do reator IEA-R1, o resfriamento é descendente e não ascendente como mostra a Fig. 18).

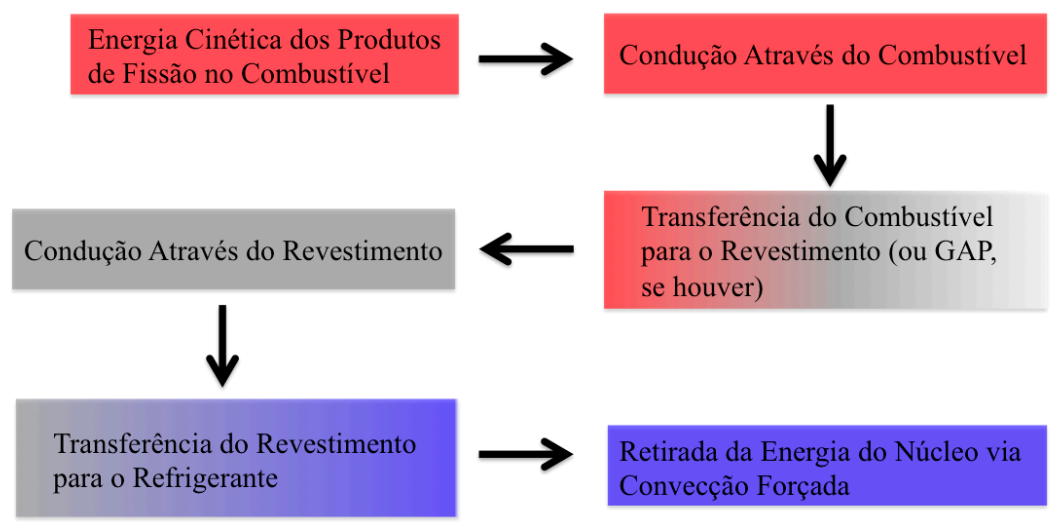

Figura 16 - Origem da Energia Térmica e sua Condução para o Exterior do Núcleo. 


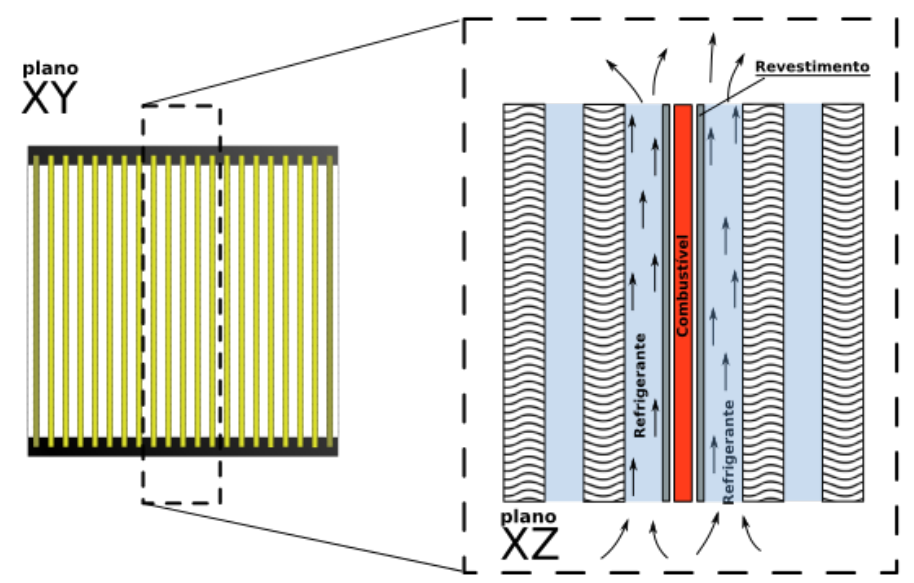

Figura 17 - Esquema de Resfriamento do Núcleo de um Reator Nuclear.

Do ponto de vista de projetos, a análise neutrônica por si só é insuficiente para predizer o bom funcionamento de um reator, pois a princípio, após considerar os quesitos de segurança (barras de controle, por exemplo), quaisquer valores de fluxos de nêutrons são admissíveis. A análise térmica/termo-hidráulica e de segurança que é necessária para avaliar os perfis de temperatura nos materiais que compõe o núcleo do reator e as margens termo-hidráulicas, que não devem ser ultrapassadas, a fím de se evitar contratempos no bom funcionamento do núcleo. Assim, aspectos relacionados à análise térmica e/ou termo-hidráulica devem ser abordados.

Os cálculos e discussões sobre as margens termo-hidráulicas e a obtenção dos perfís de temperatura na placa mais quente (maior geração de calor) de cada configuração são a tônica deste capítulo e configuram dados importantes no projeto básico de um reator nuclear.

Além disso, a relação entre os fenômenos de transferência de calor e o escoamento de fluidos (nesse caso, líquido) com a mudança de fase (no refrigerante) deve ser estudada e compreendida. Em reatores resfriados a líquidos, caso específico do reator IEA-R1, evita-se o aparecimento de regime bifásico (água + vapor) em regime normal de operação (objetivo da presente análise), mas pode ser permitido sob condições de emergência (para o aumento da transferência de calor) e transientes. 
Em reatores onde o refrigerante também funciona como moderador, a formação de bolhas acompanhada da mudança de fase diminui o poder de moderação do mesmo. Em reatores desse tipo, resfriados a líquidos, o fluxo de calor é limitado pela natureza do mecanismo de ebulição (Burnout).

Antes de se abordar os cálculos das temperaturas e margens termo-hidráulicas, faz-se necessário uma breve discussão sobre alguns aspectos relevantes no que tange à mudança de fase e os fatos dela decorrentes, pois, como mencionado, esses aspectos limitam o funcionamento dos reatores nucleares e grandezas como o fluxo de calor crítico e temperatura de ONB (Onset of Nucleate Boiling), por exemplo, decorrem desse contexto.

\section{1 - Mudança de Fase e Seus Processos}

Nesta seção serão discutidos alguns processos de mudança de fase, bem como seus conceitos recorrentes, que são utilizados na análise térmica e termo-hidráulica de reatores nucleares.

\subsection{1 - Mudança de Fase e Seus Processos: Evaporação e Ebulição}

A evaporação é o processo pelo qual o líquido se transforma em vapor. Não se deve confundir esse conceito com o de ebulição (Boiling), que é o processo no qual vapor é formado dentro de um meio de fase líquida contínua (bolhas são formadas dentro do meio líquido).

A ebulição pode assumir várias formas, podendo ser classificada como pool boiling e bulk boiling (evitou-se a tradução desses termos para preservar o jargão técnico da área).

Pool boiling é o processo no qual a formação de vapor é devido ao calor transferido ao líquido através de uma superfície em contato ou submersa no mesmo. 
Bulk boiling (ou volume boiling) diferentemente do processo anterior, ocorre na região do líquido propriamente dita (bulk region) por causa do calor gerado nessa região através de reações químicas ou nucleares. Além disso, a ebulição (pool boiling) é classificada com ebulição nucleada (Nucleate Boiling) ou ebulição tipo filme (Film Boiling). Esses dois tipos estão ilustrados na Fig. 19.

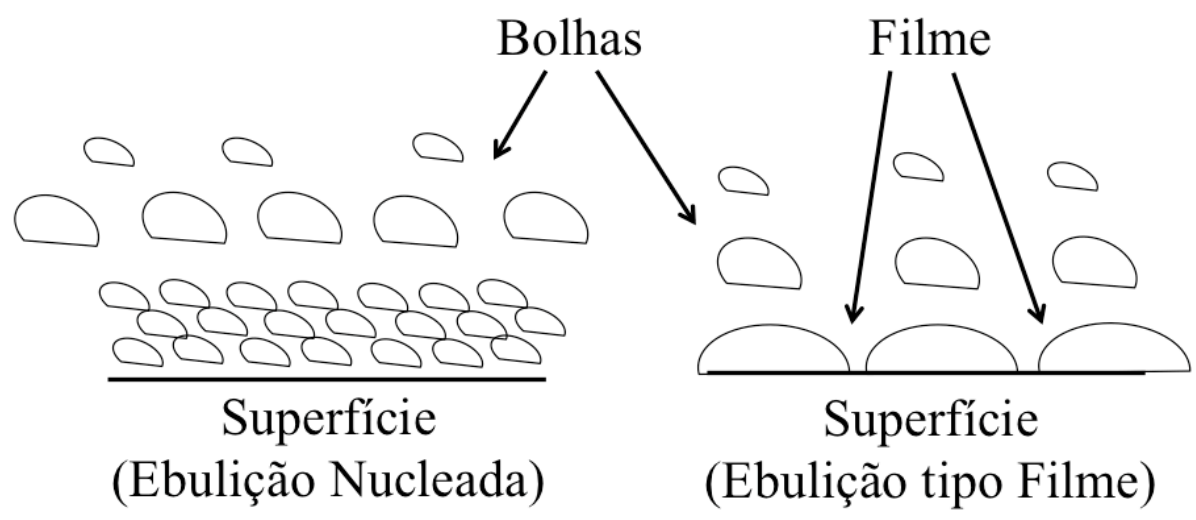

Figura 18 - Tipos de ebulição (pool boiling).

$\mathrm{Na}$ ebulição nucleada, bolhas de vapor são formadas dentro do líquido próximo a um núcleo pequeno de vapor ou gás (a formação e crescimento dessas bolhas de vapor serão discutidos depois). Dessa forma, pode haver tanto a ebulição nucleada tipo pool boiling como a ebulição nucleada tipo bulk boiling. Em contra partida, a ebulição do tipo filme consiste na formação de um filme de vapor contínuo que cobre a superfície aquecida. A ebulição tipo filme é geralmente associada somente ao tipo pool boiling. Sob certas condições, ebulição nucleada e tipo filme podem coexistirem. Esse estado pode receber vários nomes, como por exemplo ebulição tipo filme parcial (partial film boiling) e ebulição nucleada parcial (nucleate partial boiling).

Outras duas classificações aplicáveis à ebulição são a saturada e a sub-resfriada. Essas duas classificações se referem à temperatura da parte/corpo líquido (bulk). Lembrando que bulk se refere à região onde as propriedades do líquido estão relacionadas com a transferência de calor por convecção, ou seja, região além da camada limite. 
Na ebulição saturada, o corpo líquido está na temperatura de saturação correspondente à pressão do sistema. Na ebulição sub-resfriada, o corpo líquido está em uma temperatura abaixo da temperatura de saturação.

É preciso notar que, para se gerar bolhas em ambos os casos, a superfície aquecida necessita estar em uma temperatura maior que aquela de saturação e, consequentemente, parte do líquido que se encontra em regiões adjacentes à superfície deve possuir também temperatura acima de saturação. Em outras palavras, tem-se uma porção de líquido superaquecido, mesmo o Bulking estando saturado ou sub-resfriado.

$\mathrm{Na}$ ebulição saturada, as bolhas formadas sobem para a superfície do líquido onde são destacadas. Na ebulição sub-resfriada, as bolhas começam a subir, mas podem colapsar antes de atingir a superfície do líquido, veja Fig. 20.

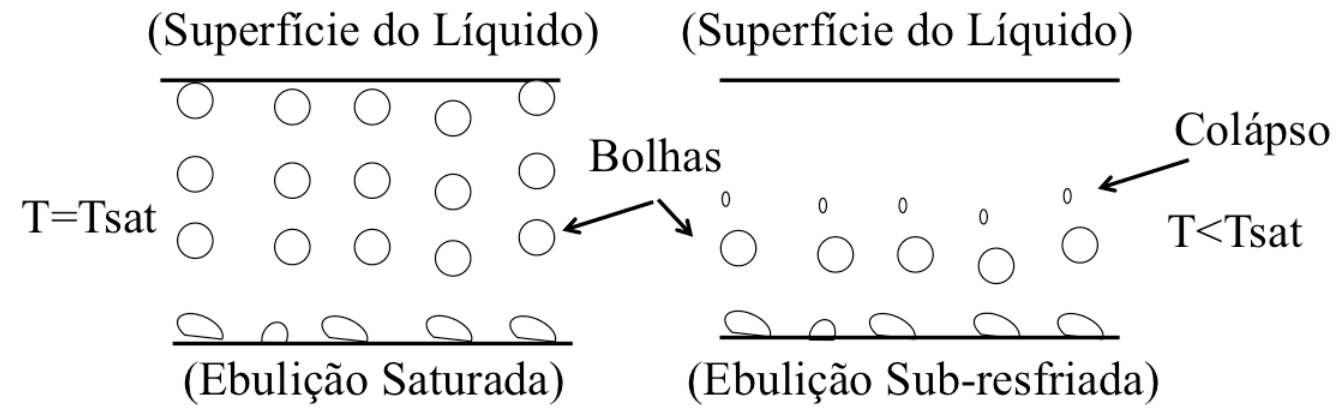

Figura 19 - Tipos de ebulição (Saturada e Sub-Resfriada).

\subsection{2 - Mudança de Fase e Seus Processos: Escoamento Bifásico}

Esse é o caso em que ambos, vapor e líquido, movem-se em um dado sistema ou canal.

Escoamento bifásico pode ser classificado como não-adiabático ou adiabático, ou seja, as bolhas podem ou não aparecerem. Também pode ser classificado como escoamento de componente simples (água + vapor d'água) ou dupla (água + ar). Em ambos os casos as velocidades das duas fases geralmente não são iguais, podendo acarretar alguns efeitos que não serão abordados no presente estudo. 


\subsection{3 - Mudança de Fase e Seus Processos: Condensação}

É o contrário da evaporação, ou simplesmente o processo de conversão de vapor para líquido. Pode se dar como um filme, quando existir um escoamento contínuo de líquido sobre uma superfície de resfriamento, ou em forma de gotas, quando o vapor condensa e a superfície de resfriamento não está completamente coberta por líquido.

\section{2 - Formação de Bolhas, Crescimento e Desprendimento}

Os processos de formação e crescimento de bolhas (chamados de nucleação), juntamente com o processo de desprendimento das mesmas para o meio líquido no tipo de ebulição pool boiling são abordados nesta seção.

\subsection{1 - Formação de Bolhas, Crescimento e Desprendimento: Subsídios para Nucleação}

As bolhas são formadas devido ao líquido superaquecido que se encontra adjacente à superfície aquecida. O grau de superaquecimento do líquido, e portanto, o mecanismo de formação das bolhas é auxiliado por três fatores:

- Presença de gás ou vapor no líquido;

- Presença de ranhuras ou cavidades na superfície aquecida;

- Característica de molhagem da superfície.

Os fatores acima citados são chamados de fatores auxiliadores da nucleação ou centros de nucleação. Centros gasosos de nucleação podem existir na forma de ar dissolvido que advém da solução no líquido aquecido. Em reatores nucleares, o número de centros de nucleação é aumentado através da presença de radiações ionizantes, hidrogênio e oxigênio resultantes da radiólise da água em reatores resfriados com esse tipo de refrigerante. 
Além dos íons funcionarem como centros de nucleação, também ajudam o movimento das bolhas, devido à força elétrica de repulsão entre bolhas que agora se encontram carregadas.

Experimentos em reatores BWR (Boiling Water Reactor) mostram que eles possuem maiores coeficientes de transferência de calor frente àqueles encontrados em aparatos convencionais que usam mecanismos de ebulição [24].

Ranhuras e cavidades agem como centros de nucleação, pois eles incorporam vapor e raramente podem ser completamente preenchidos com líquido, devido aos efeitos de tensão superficial.

As fendas também são centros de relativamente altas temperaturas, característica que promove ainda mais o processo de nucleação. $\mathrm{O}$ crescimento e liberação de uma bolha em uma fenda presente em uma superfície molhada estão ilustrados na Fig. 21.

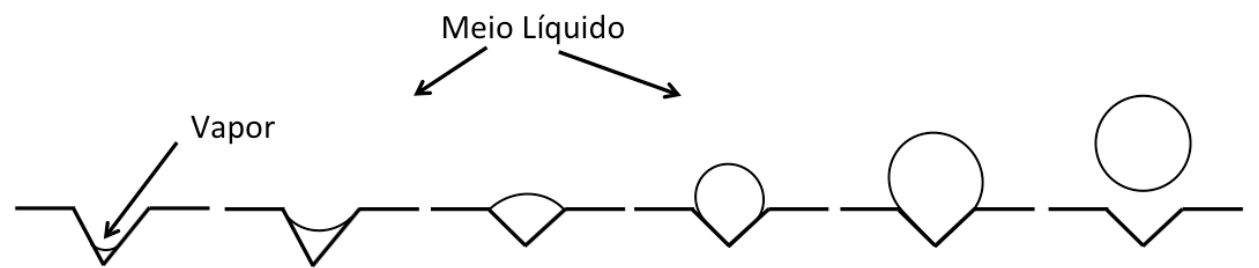

Figura 20 - Crescimento e liberação de uma bolha através da fenda presente em uma superfície aquecida e imersa em um meio líquido.

\subsection{3 - Formação de Bolhas, Crescimento e Desprendimento: Líquido Superaquecido}

Como já mencionado anteriormente, a porção de líquido que se encontra próxima à superfície aquecida deve estar em estado de superaquecimento para que se inicie a formação de uma bolha. 
Esse fato pode ser compreendido lembrando que, para que haja tal formação, certa quantidade de energia é necessária para suprir o calor latente de evaporação do líquido vaporizado e a energia superficial relacionada com os efeitos de forças de tensões do líquido. A energia total necessária deve estar contida no líquido superaquecido que se encontra em regiões adjacentes à superfície aquecida.

O grau do líquido superaquecido necessário para formar bolhas pode ser bastante alto em sistemas limpos. Entende-se por sistema limpo (ou puros) aquele em que não há vapor ou gases presentes e no qual a superfície aquecida não possua ranhuras, fendas ou cavidades, contendo então poucos ou quase nenhum centro de nucleação.

Esse tipo de sistema não existe na prática e o grau de superaquecimento do líquido é bem menor do que aquele exigido em sistemas limpos.

\subsection{4 - Formação de Bolhas, Crescimento e Desprendimento: Desprendimento das Bolhas no Meio Líquido}

O processo de liberação ou desprendimento da bolha pela superfície aquecida causa agitação no meio líquido e, portanto, afeta consideravelmente o coeficiente de transferência de calor em transferência de calor por ebulição.

A bolha se desprende quando possui tamanho grande o suficiente para que os efeitos de empuxo (flutuabilidade) superem os de capilaridade, efeito este, responsável por mantêla presa à superfície aquecida. Quanto maior a razão entre o volume da bolha e a área de contato, mais fácil seu desprendimento. A Fig. 22 ilustra a agitação da fase líquida causada pela formação, crescimento e desprendimento (ou colapso em ebulição subresfriada) da bolha. A agitação na fase líquida devido à formação da bolha faz com que a porção de líquido quente que estava nas adjacências da superfície aquecida seja expulsa por tal perturbação no local e, conforme a bolha vai se desprendendo, a parcela de líquido mais frio vai ocupando o "Gap" criado pela mesma. 
Assim, há uma contínua mistura que tende a aumentar conforme mais bolhas são formadas (i.e., com o aumento do fluxo de calor), sendo essa a razão do maior coeficiente de transferência de calor possível com a ebulição nucleada.

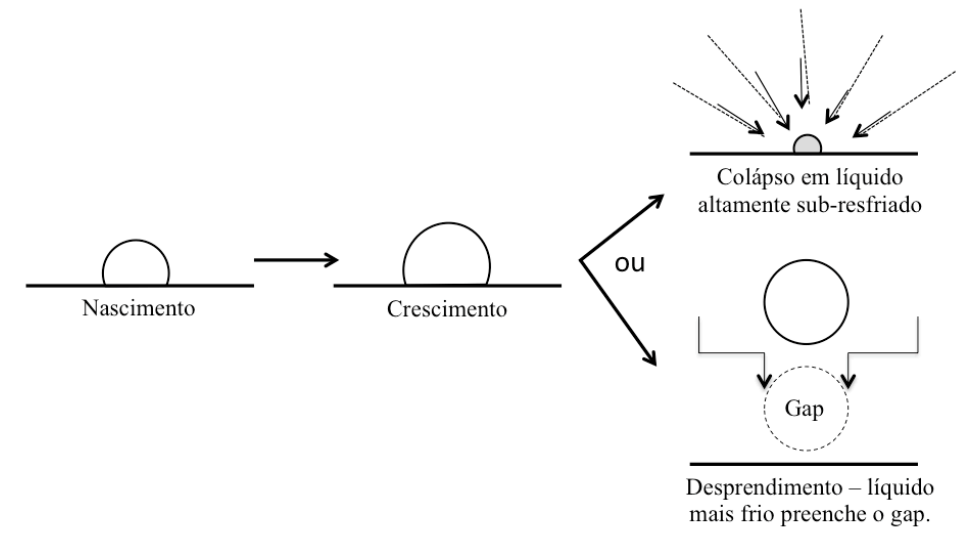

Figura 21 - Agitação da fase líquida na ebulição.

À medida que as bolhas vão subindo no meio líquido, elas podem permanecer separadas (baixos fluxos de calor) ou interferir com outras, conforme o fluxo de calor aumenta. Nesse último caso, uma coluna oscilante de vapor é formada, causando o aumento do coeficiente de transferência de calor com o fluxo de calor.

\section{3 - Ebulição e seus Regimes}

Com a breve introdução apresentada sobre a dinâmica de formação de bolhas, é possível agora classificar os diversos regimes de ebulição. A Fig. 23 ilustra a representação convencional do fluxo de calor $q^{\prime \prime}$ (taxa de transferência de calor por unidade de área) com a variação $\Delta T$ de temperatura, diferença essa entre a temperatura da superfície e aquela da fase líquida (bulk).

A curva apresentada é para o caso em que a temperatura da fase líquida esteja na temperatura de saturação, correspondente a sua pressão, por isso muitas vezes essa figura é apresentada como tendo no eixo das coordenadas o valor $T-T_{\text {sat }}$, ao invés de $\Delta T$. 
Devido às grandes variações na magnitude de $q^{\prime \prime}$ e $\Delta T$, a curva é geralmente plotada em formato $\log -\log$. Lembrando que o coeficiente de transferência de calor, $h$, também pode ser ilustrado e possui a mesma forma do gráfico da Fig.23 $\left(h=q^{\prime \prime} / \Delta T\right)$, apenas sendo deslocada do mesmo.

A curva apresentada na Fig. 23 é geralmente dividida em 6 parte. Antes de a, a temperatura da superfície aquecida é próxima, ou somente alguns graus acima da temperatura do líquido. Assim, não há líquido superaquecido suficiente para formar bolhas. A transferência de calor nessa região do gráfico é, portanto, através da convecção natural somente. Na convecção natural, o fluxo de calor $q^{\prime \prime}$ varia pouco com a variação da temperatura (supondo que esta seja uma variável independente para a presente análise).

O calor transferido é então transportado pelas bolhas que sobem pela fase líquida, onde algumas delas podem evaporar caso atinjam a superfície superior (interface líquido-ar, por exemplo).

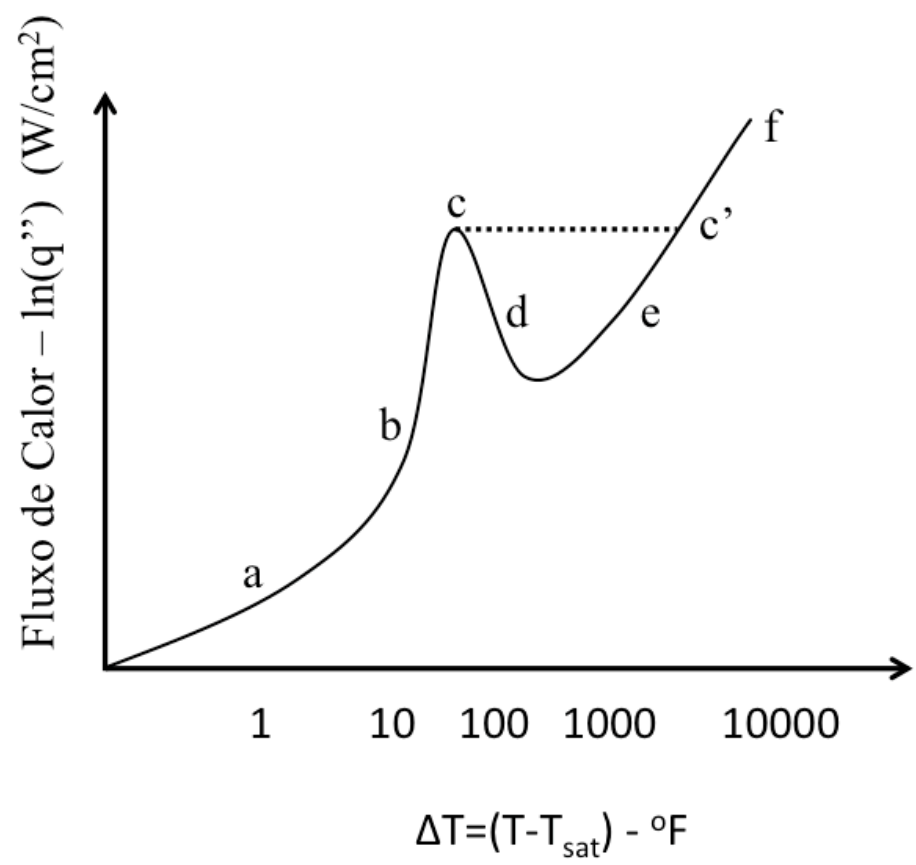

Figura 22 - Regimes de Ebulição: até a, convecção; entre a e b, mistura (transição, início de bolhas isoladas); entre b e c, ebulição nucleada; entre c e d, transição (formação parcial de filme); entre d e e, ebulição com filme; entre e e f, ebulição com filme e radiação. 
Conforme a temperatura da superfície aquecida cresce, o fluxo de calor aumenta e o regime situado entre a e b aparece. Neste, o fluxo de calor é ainda pequeno, ou seja, somente poucos centros de nucleação são formados e somente poucas bolhas são formadas. Essas bolhas sobem rapidamente podendo colapsar no caminho.

A leve agitação no meio, causada por essas bolhas, provoca um aumento mais rápido no fluxo de calor e também no coeficiente de transferência de calor com $\Delta T$. O regime entre a e b é uma mistura e a transferência de calor é promovida pela combinação da convecção natural e da agitação causada pelas bolhas.

Havendo aumento em $\Delta T$, o regime entre b e c surge. Nesse caso, o número de centros de nucleação e, consequentemente, o número de bolhas aumentam rapidamente com $\Delta T$. Esse aumento no número de bolhas causa agitação e turbulência consideráveis no líquido presente na camada limite, fazendo com que o fluxo de calor aumente com $\Delta T$. O regime em discussão é chamado de regime de ebulição nucleada e apresenta altas taxas de fluxo de calor com moderados valores para $\Delta T$, ou seja, moderados valores para a temperatura da superfície em contato com o líquido.

O fluxo de calor no ponto c pode receber vários nomes, dentre eles tem-se:

- Fluxo de Calor de Máxima Nucleação;

- Fluxo de Calor Crítico;

- Pico de Fluxo de Calor;

- Fluxo de Calor onde ocorre a saída do regime de ebulição nucleada (Departure from Nucleate Boiling - DNB), ou seja, Fluxo de Calor DNB.

A diferença de temperatura associada ao ponto c é comumente referida como diferença de temperatura crítica ou de máxima nucleação.

À medida que a diferença de temperatura $\Delta T$ cresce para além do valor crítico, o regime entre $\mathbf{c}$ e $\mathbf{d}$ aparece. 
As bolhas tornam-se tão numerosas que começam a aderir umas nas outras e se aglomeram perto da superfície aquecida. Assim, uma porção da superfície fica coberta por vapor. Essa camada de vapor atua como um isolante térmico, uma vez que conduz de forma ineficiente o calor.

O regime c-d pode ser alcançado, experimentalmente, somente se a temperatura da superfície puder ser precisamente controlada. Entretanto, se o fluxo de calor for o parâmetro de controle, o regime c-d se torna instável.

Um pequeno aumento em $\Delta T$, por exemplo, causa um aumento momentâneo no fluxo de calor, propiciando este o surgimento de mais cobertura por vapor na superfície e, consequentemente, diminuição do fluxo de calor. A camada ou filme de vapor colapsa e se reconstrói periodicamente.

Vários nomes são dados ao regime c-d, tais como: regime de nucleação parcial, filme parcial, mistura de nucleação e filme e transição para o regime por filme.

Diferentemente do regime anterior, no regime entre d e e uma camada contínua de vapor se forma sobre a superfície aquecida e o coeficiente de transferência de calor atinge um valor mínimo (se comparado com os valores dentro desse regime!). Esse regime é chamado de regime de ebulição por filme (ou regime de filme estável).

No regime e-f, a temperatura da superfície aquecida é tão alta que radiação térmica é emitida pela mesma. A radiação térmica é fortemente dependente da temperatura $\left(\propto T^{4}\right)$ e o fluxo de calor cresce rapidamente com $\Delta T$. O local exato do ponto e depende de características da superfície e do líquido (emissividade e absortividade). É chamado de regime por filme e radiação.

É possível constatar que um mesmo fluxo de calor pode ser obtido através de três temperaturas diferentes (veja Fig. 23). É bastante razoável perceber também que o regime ideal para se trabalhar em sistemas à ebulição é aquele situado entre b e c somente, uma vez que altos valores de fluxo de calor podem ser obtidos de maneira estável e com moderadas temperaturas na superfície. 


\section{4 - Boiling Crisis e Burnout}

A curva apresentada na Fig. 23 é obtida quando a temperatura da superfície aquecida é rigorosamente controlada. Entretanto, na prática, onde a superfície aquecida é aquela presente em elementos combustíveis, é o fluxo de calor que é controlado e não a temperatura.

Assim, o fluxo de calor mostrado na Fig. 23 se torna a variável independente e $\Delta T$, a variável dependente. Nesse caso, quando o fluxo crítico (c) e a temperatura correspondente são alcançados, um novo aumento no fluxo de calor resulta em um repentino salto de c a c', atingindo o regime por filme e radiação e-f. Isso faz com que a diferença de temperatura mude abruptamente do valor em c para o valor em c'.

A temperatura da superfície aquecida em c' é tão elevada que muito provavelmente excede os limites de segurança. Nessa condição, diz-se que a superfície "queimou" (burnout, não confundir com burnup, onde esse último será tratado em seções posteriores).

O fenômeno de burnout em um elemento combustível pode culminar na ruptura de seu revestimento, liberando no refrigerante uma grande quantidade de gases e sólidos radioativos. Em todo caso, o fluxo de calor correspondente à temperatura de burnout da superfície é chamado de fluxo de calor burnout.

Esse fluxo não necessariamente é somente aquele associado aos pontos c e c', pois o fenômeno de burnout pode ocorrer em qualquer ponto da curva apresentada na Fig. 23, dependendo do tipo de material da superfície em questão, bem como das condições de operação. Entretanto, na maioria dos casos, o burnout ocorre quando o fluxo de calor em c, chamado de fluxo de calor crítico $q^{\prime \prime}{ }_{c}$, é excedido.

Como já percebido, os termos fluxo de calor crítico e fluxo de calor burnout são geralmente usados para descrever o fluxo de calor em c, embora não devam ser confundidos. 
Da mesma forma, já foi mencionado que, no ponto c, tem-se a condição DNB (Departure from Nucleate Boiling), o que também pode receber o nome de crise ou colapso hidrodinâmico (hydrodynamic crisis) ou crise ou colapso da ebulição (boiling crisis).

7.5 - Cálculo das Margens de Segurança MDNBR e FIR, Temperatura de ONB, Perfis de Temperatura para o Canal mais Quente de Cada Configuração e Velocidade Crítica de Escoamento

Através da discussão anterior, pode-se ter noção da importância em saber identificar parâmetros como o fluxo de calor crítico, a temperatura para início da ebulição nucleada (Onset of Nucleate Boiling), dentre outros.

No presente estudo, é fundamental evitar o aparecimento de bolhas ao longo dos canais de resfriamento, pois o reator IEA-R1 foi projetado para trabalhar, em regime normal de operação, com somente água na fase líquida. Isso sem levar em conta a queda no poder de moderação devido ao surgimento das mesmas, conforme já discutido anteriormente, uma vez que a água também faz papel de moderador, além de refrigerar os elementos do núcleo.

\subsection{1 - Margens de Segurança: MDNBR}

Para evitar que o fluxo de calor atinja o fluxo de calor crítico, fazendo com que a temperatura na superfície do revestimento atinja valores demasiado altos, define-se a margem termo-hidráulica MDNBR, que mede a razão mínima entre o fluxo crítico e o fluxo de calor local.

Observe que, fisicamente, essa margem de segurança informa o quão próximo o fluxo de calor, em determinada parte do elemento combustível, se encontra do fluxo de calor crítico, daí a sua importância. Para o cálculo dessa margem termo-hidráulica, utilizando o programa computacional MTRCR-IEAR1, duas correlações foram utilizadas: a de Labuntsov (mais conservativa) [25] e a de Mirshak [26] (Eq. 10 e 11), ambas presentes no input do referido código no Apêndice C. 


$$
\begin{aligned}
& M D N B R_{\text {Labuntsov }}=\frac{q^{\prime \prime} \text { critico-Labuntsov }}{q^{\prime \prime} \text { Local }} \\
& M D N B R_{\text {Mirshak }}=\frac{q^{\prime \prime} \text { crítico-Mirshak }}{q^{\prime \prime} \text { Local }}
\end{aligned}
$$

\subsection{2 - Margens de Segurança: FIR}

Outra margem importante é a chamada margem FIR, que mede a razão entre o fluxo de calor que induz instabilidade no escoamento e o fluxo de calor local. Instabilidades no escoamento do fluido refrigerante são indesejáveis em canais aquecidos, pois oscilações no escoamento do fluido afetam as características de transferência de calor local e podem induzir a um prematuro fluxo de calor crítico.

Para sistemas de baixa pressão com ebulição sub-resfriada, instabilidades no escoamento do fluido refrigerante levando ao fluxo de calor crítico foram observadas [27]. O fluxo de calor crítico que ocorria sob condições de escoamento instável estava bem abaixo do fluxo de calor crítico para o mesmo canal sob condições de escoamento estável.

A instabilidade do fluido refrigerante não pode ocorrer em um escoamento monofásico, exceto através de vibrações induzidas pelo mesmo ou deformações no canal. Em escoamentos bifásicos, a presença de vapor de água saturado na forma de bolhas atua como um novo mecanismo que afeta a relação vazão-queda de pressão de uma maneira complexa.

Quando a potência fornecida ao canal de resfriamento é aumentada, bolhas são formadas (ebulição sub-resfriada), primeiramente em tamanhos reduzidos e, em seguida, em tamanhos maiores.

Essa bolhas maiores podem restringir a seção transversal do canal de resfriamento e forçar a fase líquida a acelerar, de forma que a vazão se mantenha constante. Essa aceleração leva a um aumento da queda de pressão, restringindo ainda mais a passagem do fluido, levando ao seu bloqueio completo. 
Esses fenômenos são divergentes e oscilatórios sob condições apropriadas e associam o tamanho da bolha ou a fração de vazios com o início da instabilidade no escoamento. $\mathrm{O}$ fluxo de calor médio para o início da instabilidade no escoamento do fluido pode ser obtido em termos da velocidade, geometria do canal e propriedades do fluido [28].

\subsection{3 - Cálculo das Margens MDNBR e FIR}

Nesta seção encontram-se os resultados dos cálculos para as margens termo-hidráulicas MDNBR e FIR em um regime de operação estacionário. Vale lembrar que o programa computacional MTRCR-IEAR1 faz uma discretização nodal e esta última está distribuída da seguinte maneira (isto será mantido para os cálculos dos perfis de temperatura e demais variáveis termo-hidráulicas e de segurança relevantes para o presente estudo):

- 1 nó no centro do combustível;

- 1 nó na interface combustível-revestimento;

- 1 nó na interface revestimento-refrigerante;

- 1 nó no refrigerante (bulk);

Em princípio, o número de nós axiais pode variar, mas esse número foi fixado como sendo 21 (outros programas também utilizam esse número e, no presente caso, é um bom número para que não se tenha dependência da malha no resultado final). Tal distribuição de nós é feita para a placa combustível mais quente em cada um dos novos arranjos, uma vez que as demais temperaturas no núcleo em questão estarão abaixo das calculadas, ou seja, garantindo-se os parâmetros e temperaturas para a placa mais quente, automaticamente essas condições também serão satisfeitas para as demais placas.

$\mathrm{Na}$ presente análise, todas as barras de controle estão fora da parte ativa do núcleo. A diferença para o caso em que as barras de controle estão parcialmente dentro do núcleo é que, neste caso, o perfil de fluxo será achatado em direção à base. 
Entretanto, como procuram-se casos extremos, considerou-se todas as barras de controle fora do núcleo (fora da região ativa). A Tabela 4 mostra, em resumo, os valores mínimos e máximos para as margens temo-hidráulicas MDNBR e FIR obtidas para cada uma das novas configurações estudadas.

Os valores para a vazão dispostos na Tabela 4 foram tais que as temperaturas na interface revestimento-refrigerante ficassem abaixo de 90 graus, para evitar o aumento da probabilidade de corrosão no Alumínio do revestimento $\left(\sim 95^{\circ} \mathrm{C}\right)$.

As Figuras, de 24 a 32, ilustram o comportamento dessas margens ao longo do canal de resfriamento mais quente. A reta $y=2$ representa o valor de segurança para essas margens.

Tabela 4 - Valores mínimos para as margens MDNBR e FIR.

\begin{tabular}{|c|c|c|c|c|}
\hline & \multicolumn{2}{|c|}{ Mínimo } & \multirow[b]{3}{*}{ FIR } & \multirow[b]{3}{*}{ Fluxo $\left(\mathrm{m}^{3} / \mathrm{h}\right)$} \\
\hline & \multicolumn{2}{|c|}{ MDNBR } & & \\
\hline & Labuntsov & Mirshak & & \\
\hline Núcleo 5 & 5 & 5 & 9 & $60(\mathrm{FE})$ \\
\hline Núcleo 6 & 5 & 5 & 9 & $55(\mathrm{FE})$ \\
\hline Núcleo 7 & 4 & 4 & 5 & 35 (CE) \\
\hline Núcleo 8 & 6 & 6 & 9 & 45 (FE) \\
\hline Núcleo 8* & 4 & 5 & 6 & $30(\mathrm{CE})$ \\
\hline Núcleo 9 & 6 & 6 & 8 & $40(\mathrm{FE})$ \\
\hline Núcleo 10 & 6 & 6 & 8 & 35 (FE) \\
\hline Núcleo 12 & 6 & 7 & 7 & $30(\mathrm{FE})$ \\
\hline Núcleo $12 *$ & 5 & 6 & 5 & $20(\mathrm{CE})$ \\
\hline
\end{tabular}




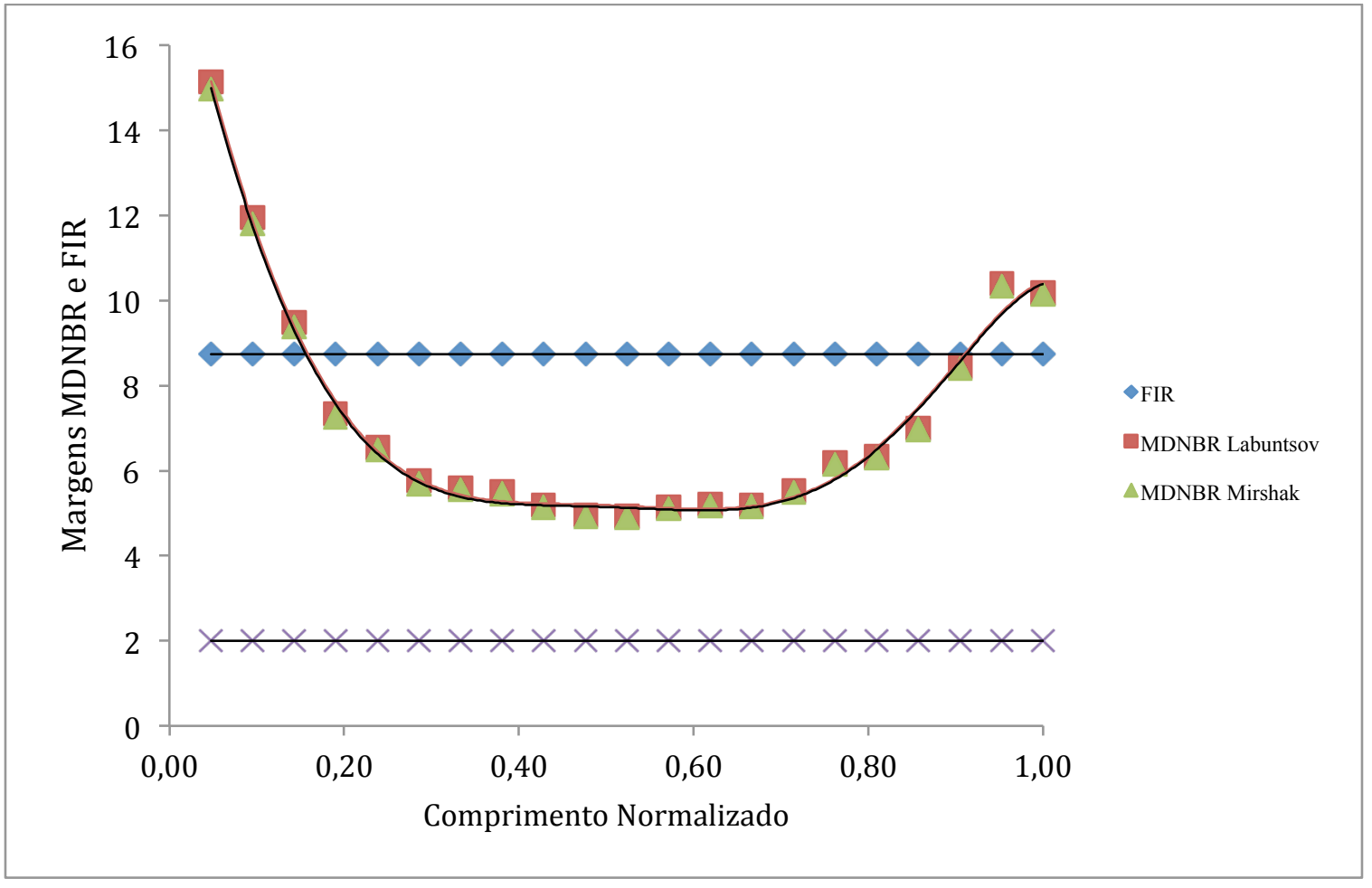

Figura 23 - Núcleo 5: Margens MDNBR e FIR.

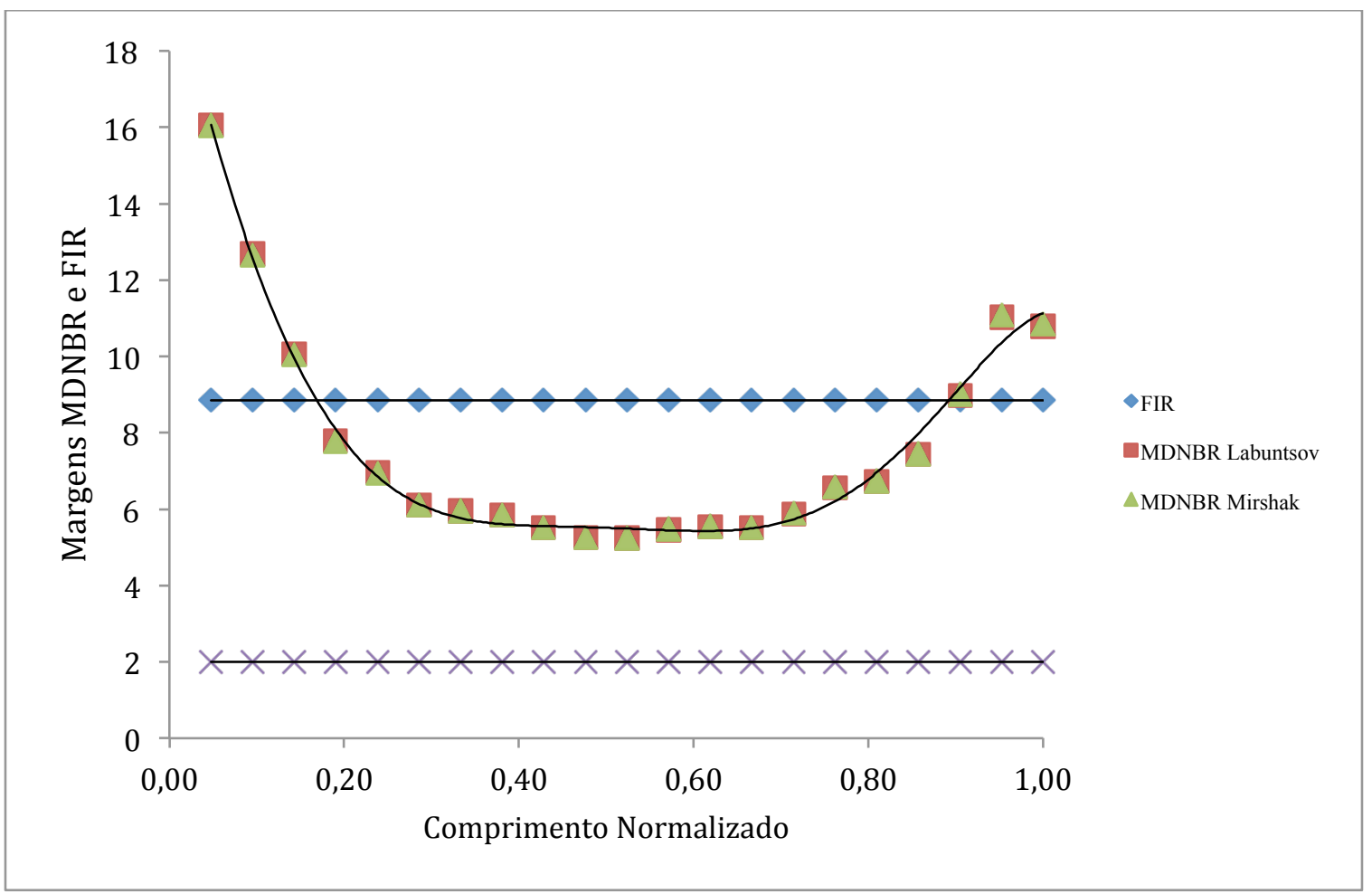

Figura 24 - Núcleo 6: Margens MDNBR e FIR. 


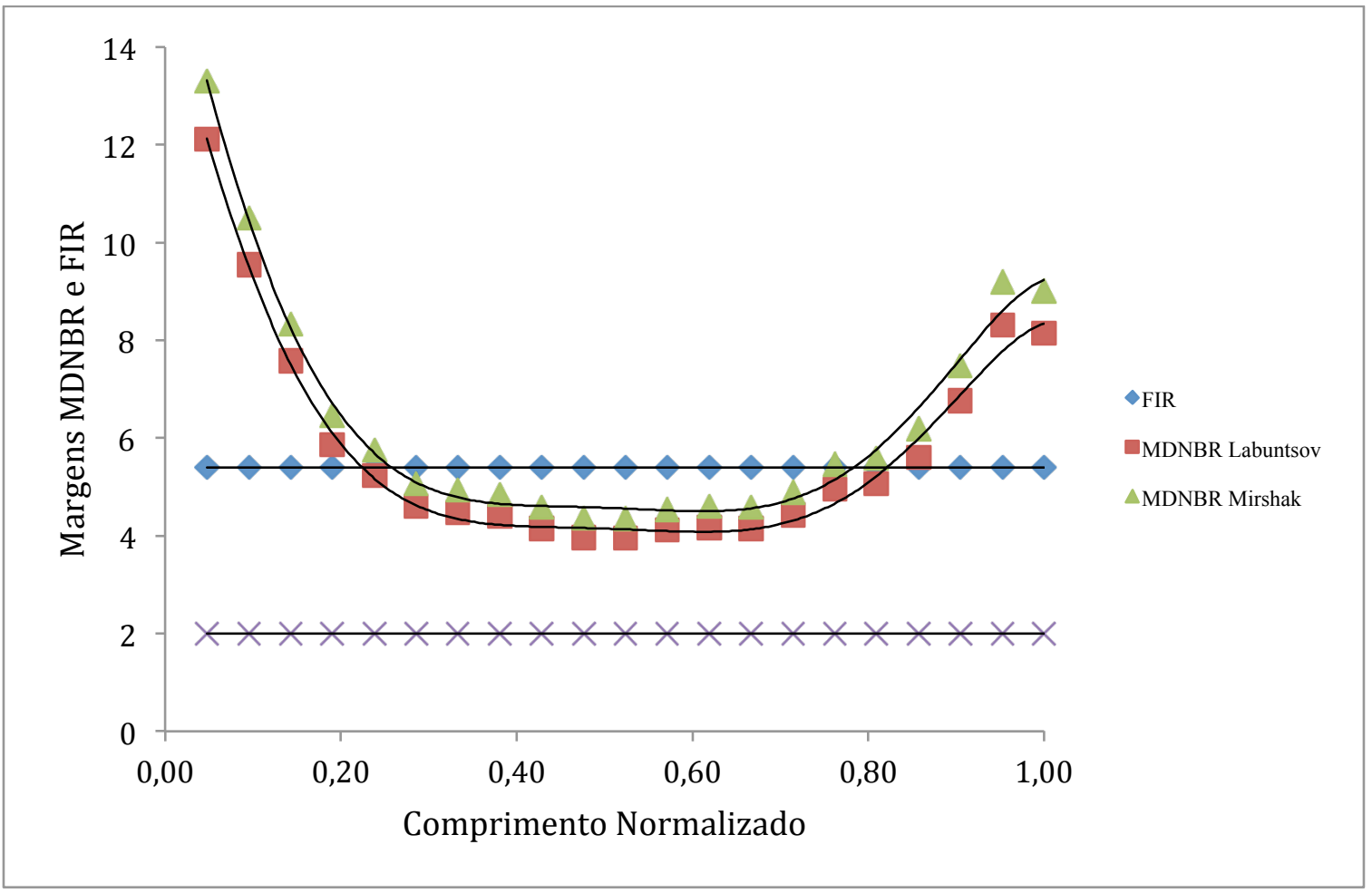

Figura 25 - Núcleo 7: Margens MDNBR e FIR.

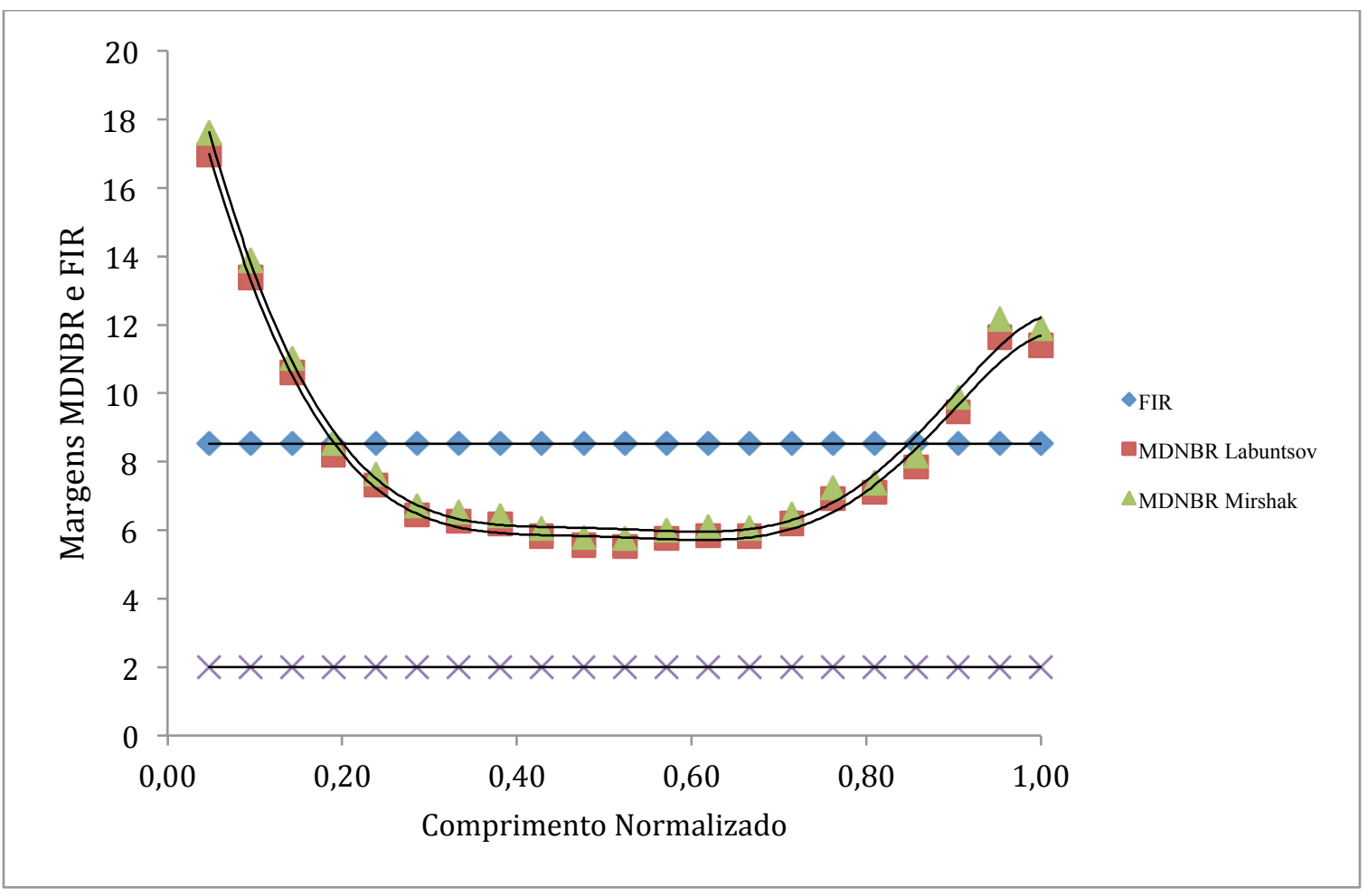

Figura 26 - Núcleo 8: Margens MDNBR e FIR. 


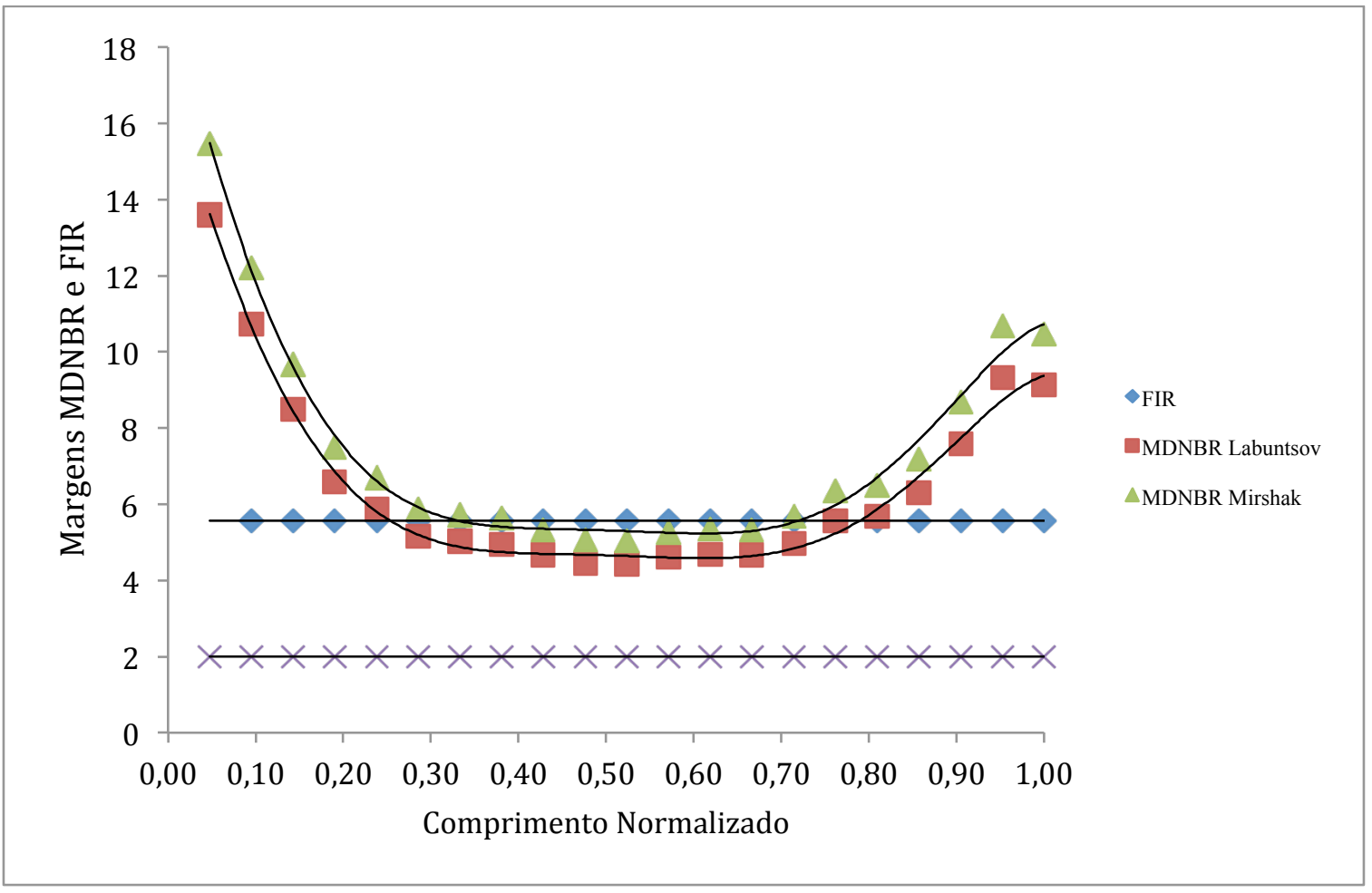

Figura 27 - Núcleo 8*: Margens MDNBR e FIR.

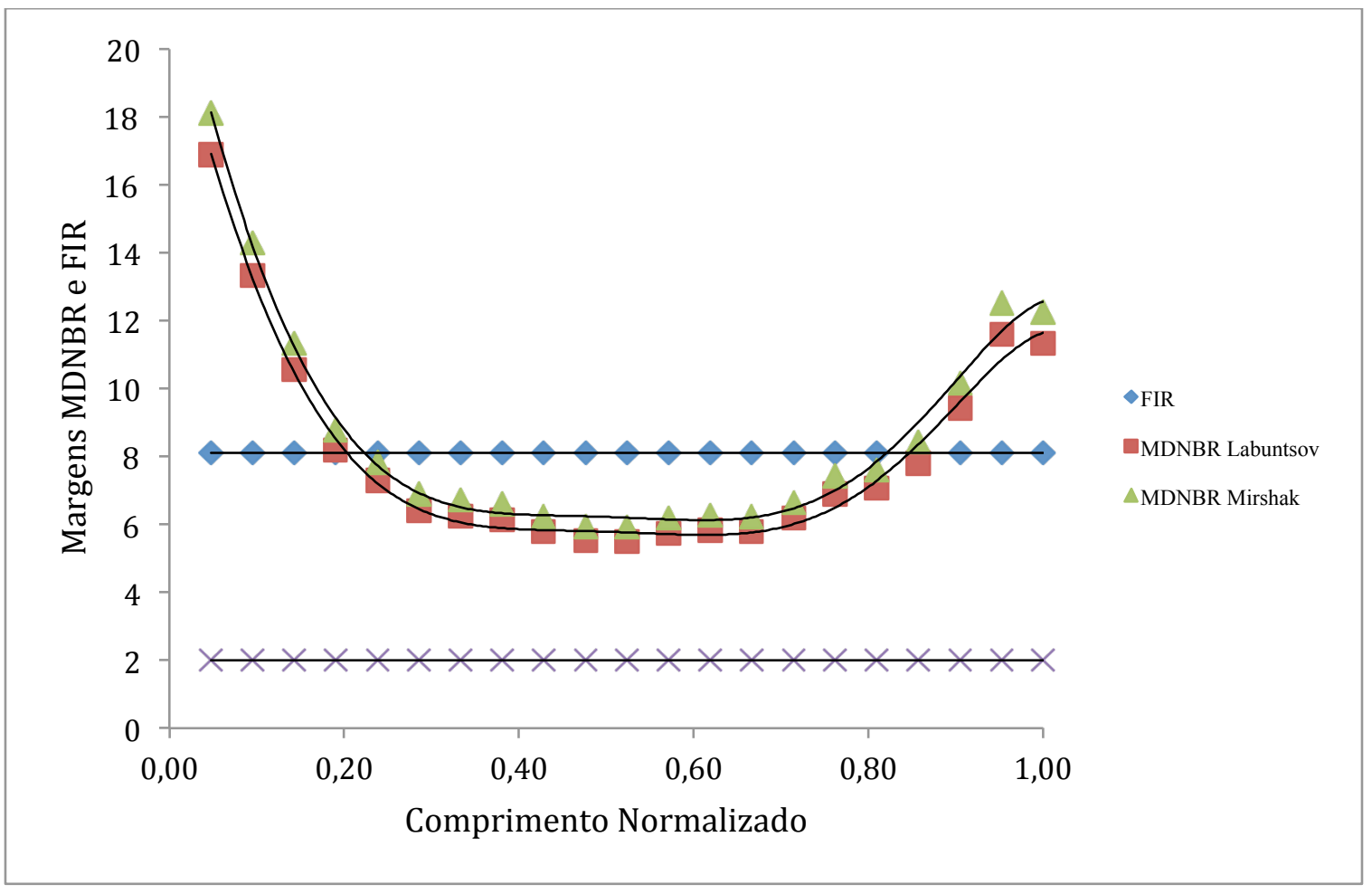

Figura 28 - Núcleo 9: Margens MDNBR e FIR. 


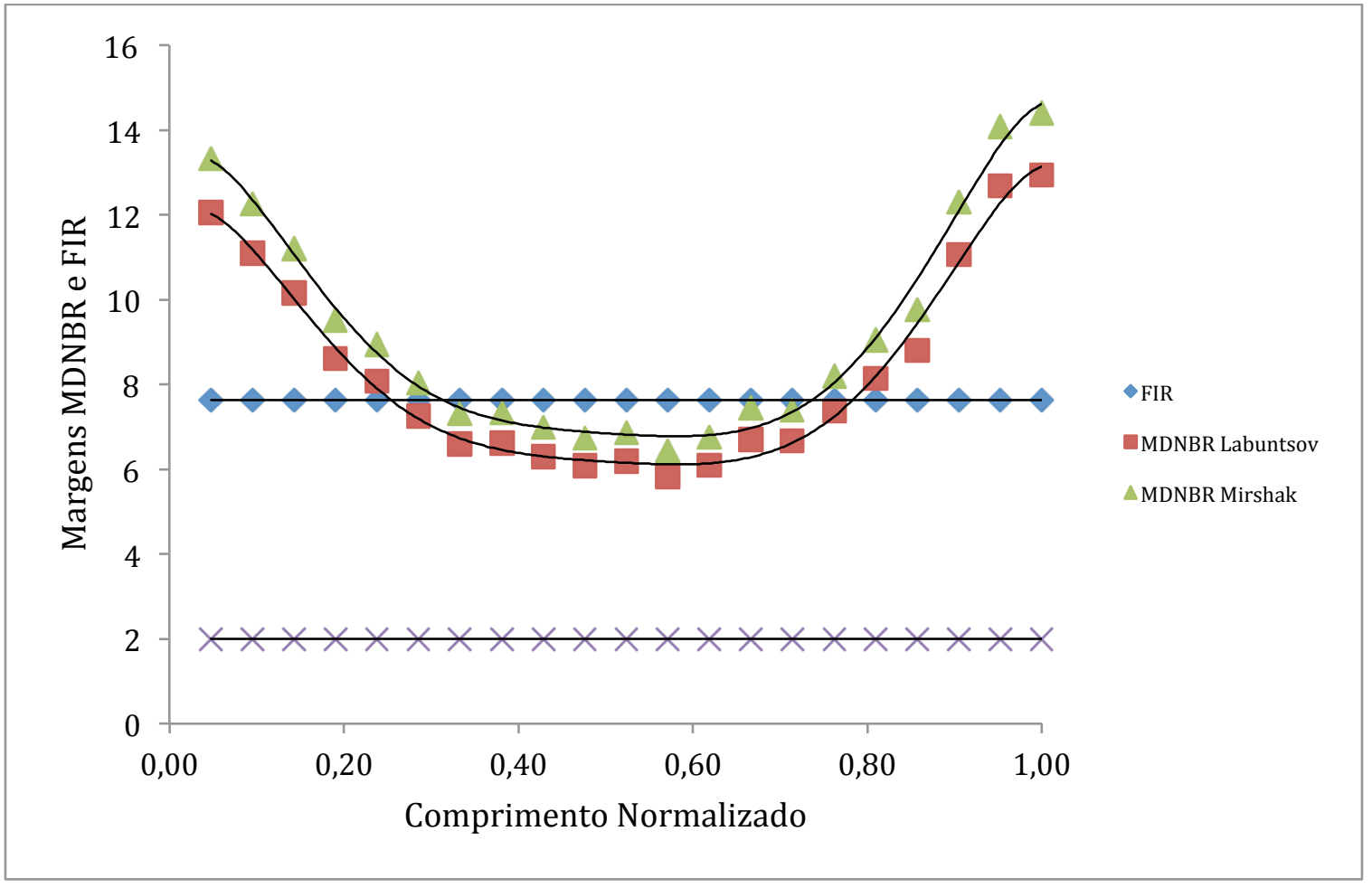

Figura 29 - Núcleo 10: Margens MDNBR e FIR.

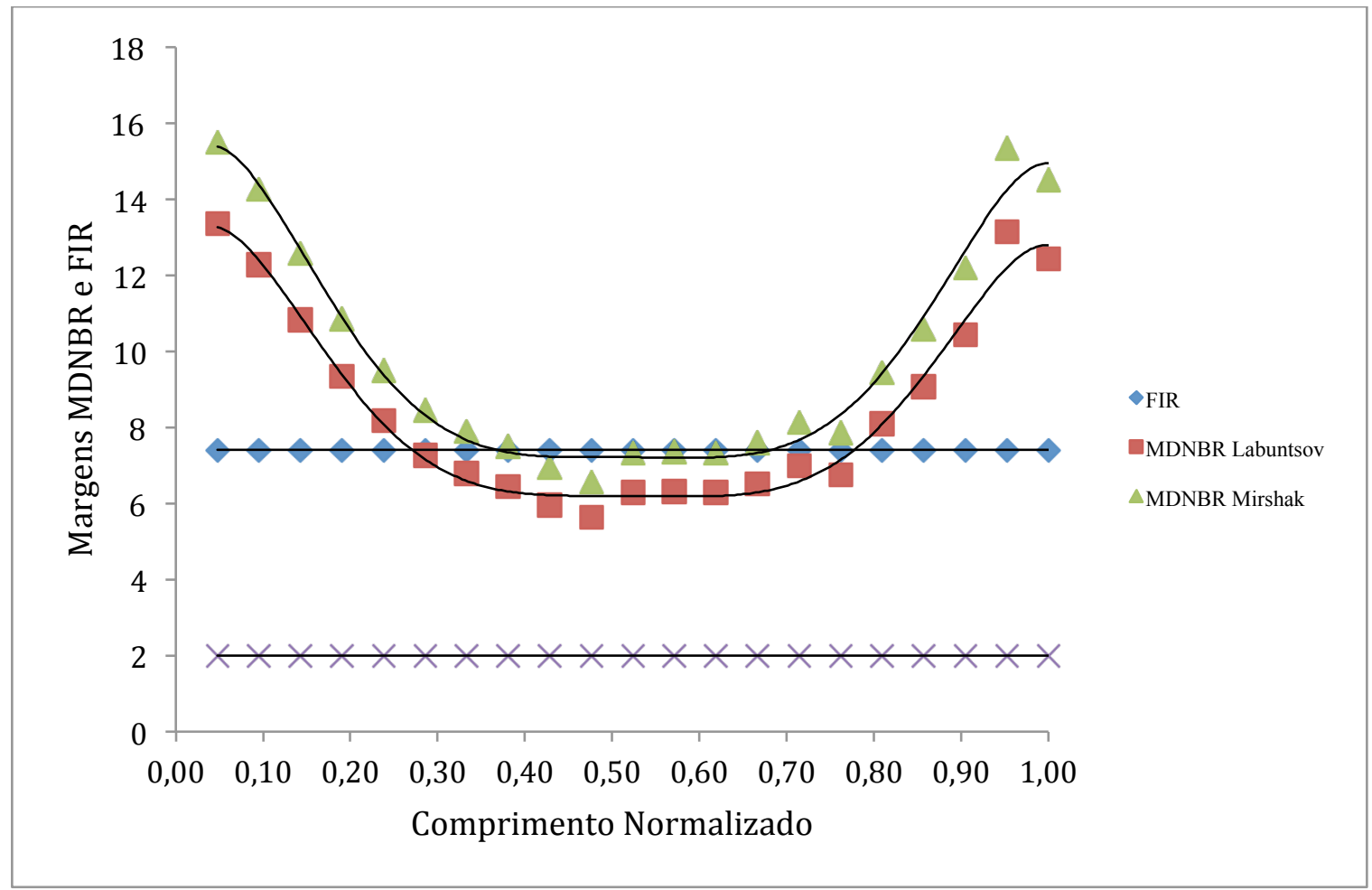

Figura 30 - Núcleo 12: Margens MDNBR e FIR. 


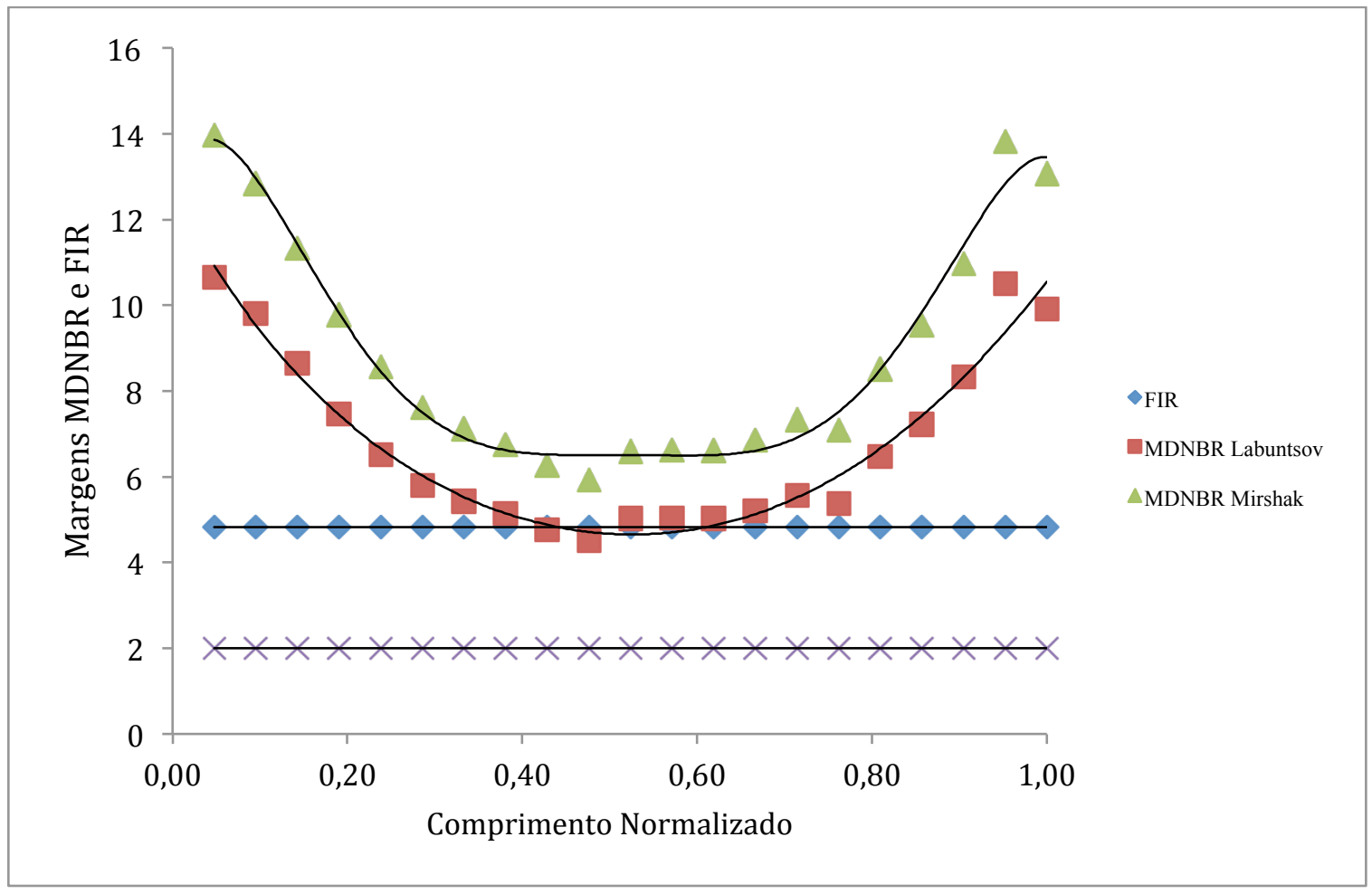

Figura 31 - Núcleo 12*: Margens MDNBR e FIR.

\subsection{4 - Cálculo dos Perfis de Temperatura e Temperatura de ONB}

Nesta seção estão dispostos os perfis de temperatura para as placas combustíveis mais quentes de cada nova configuração. Juntamente a isso, estão dispostas as temperaturas para o início da ebulição nucleada (ONB) que, como visto anteriormente, deve ser evitada.

O início da ebulição nucleada não é um critério limitante no projeto de um elemento combustível. Entretanto, é um regime de transferência de calor que deve ser identificado por considerações hidráulicas e térmicas, isto é, mudança do escoamento monofásico para o escoamento bifásico.

Sob condições de ONB, a temperatura na superfície do revestimento, sob a qual ocorre ebulição nucleada para uma dada pressão local do fluido refrigerante e fluxo de calor superficial, é dada pela correlação de Bergles e Rosenow (Eq. 12). 
Assim, sempre que possível, a temperatura na superfície da placa combustível deve ficar abaixo desse valor, a fim de evitar condições de instabilidade de escoamento e DNB.

$$
T_{\text {ONB }}=T_{\text {Sat }}+\frac{5}{9}\left(9,23 \frac{q^{\prime \prime}}{P^{1,156}}\right)^{\frac{P^{0,0234}}{2,160}}
$$

Os perfis de temperaturas estão ilustrados nas figuras a seguir (da Fig. 33 a Fig. 50).

Ressalta-se que esses perfis foram calculados para um intervalo de vazões pré-definidos (a bomba do reator IEA-R1 fornece um valor de vazão por elemento combustível ou de controle que está dentro desse intervalo, possuindo um valor total de $681,4 \mathrm{~m}^{3} / \mathrm{h}$ ) e também fixando o valor das mesmas como sendo aqueles apresentados na Tabela 4, para que se possa verificar o comportamento das temperaturas de forma axial.

Ressaltando que, para as figuras onde são ilustradas a variação de temperatura com a vazão no elemento combustível, a mesma é aquela referente ao canal mais quente em cada configuração.

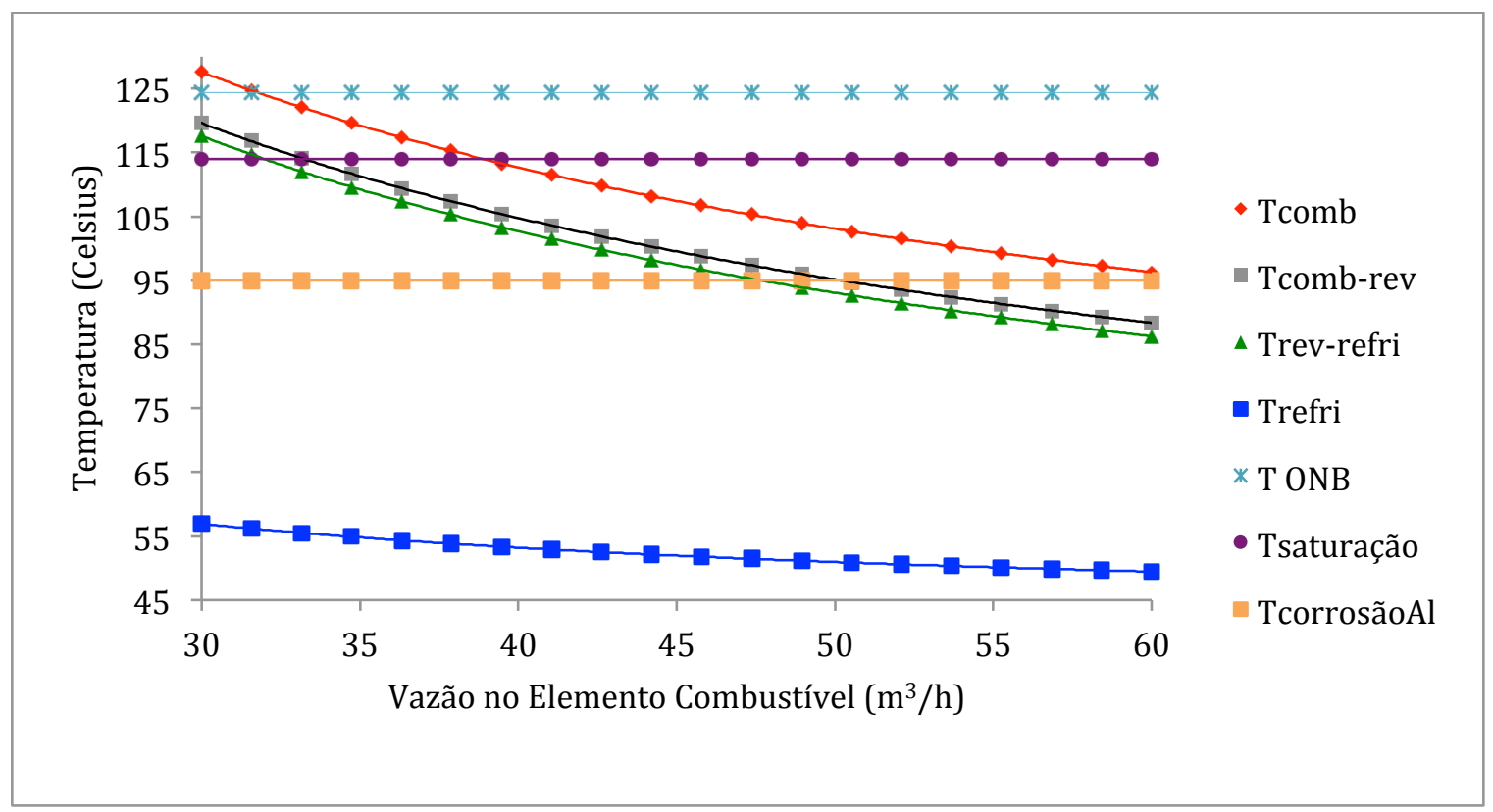

Figura 32 - Núcleo 5: Perfil de temperatura. 


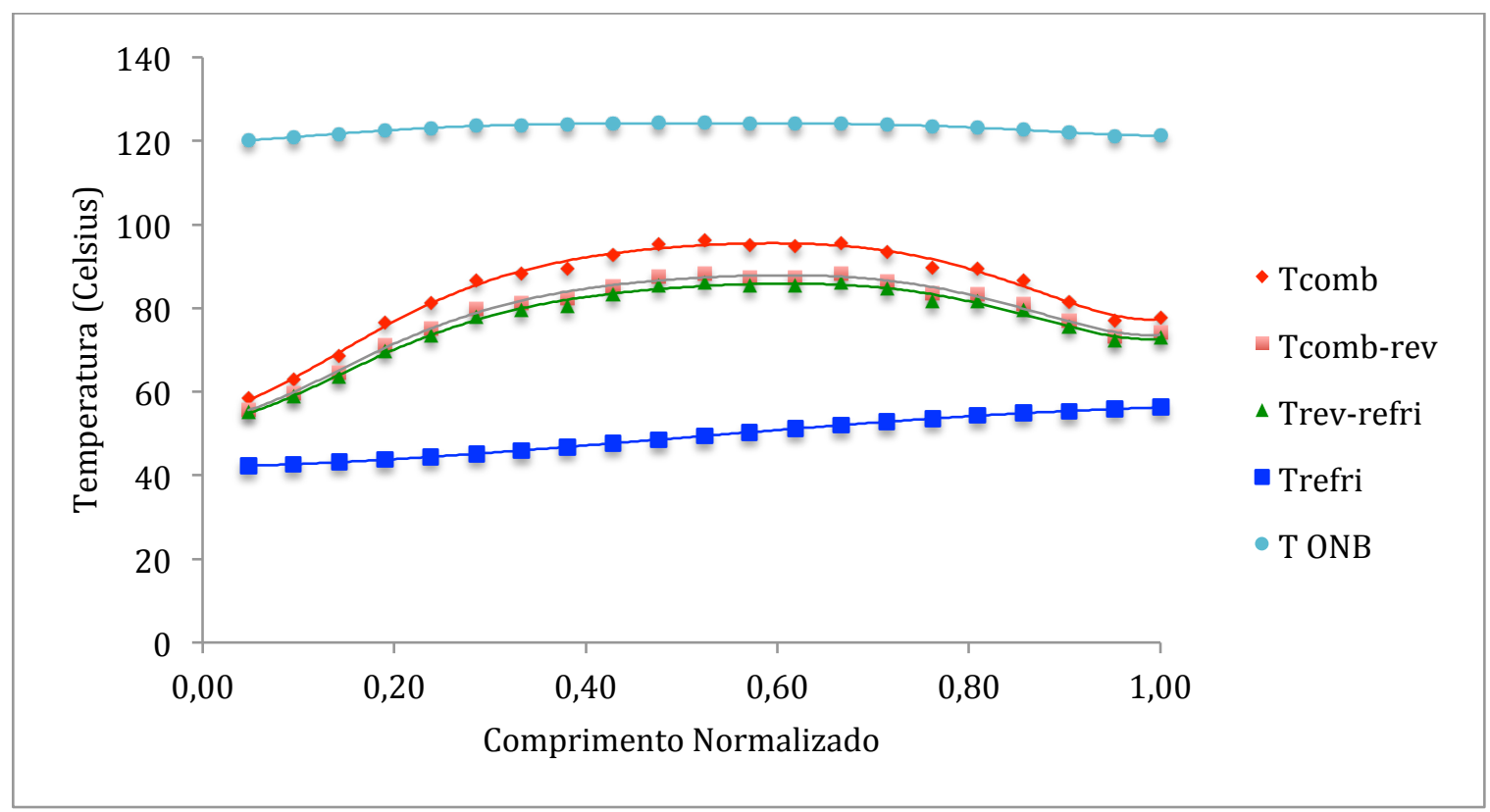

Figura 33 - Núcleo 5: Perfil de temperatura. Vazão $60 \mathrm{~m}^{3} / \mathrm{h}$.

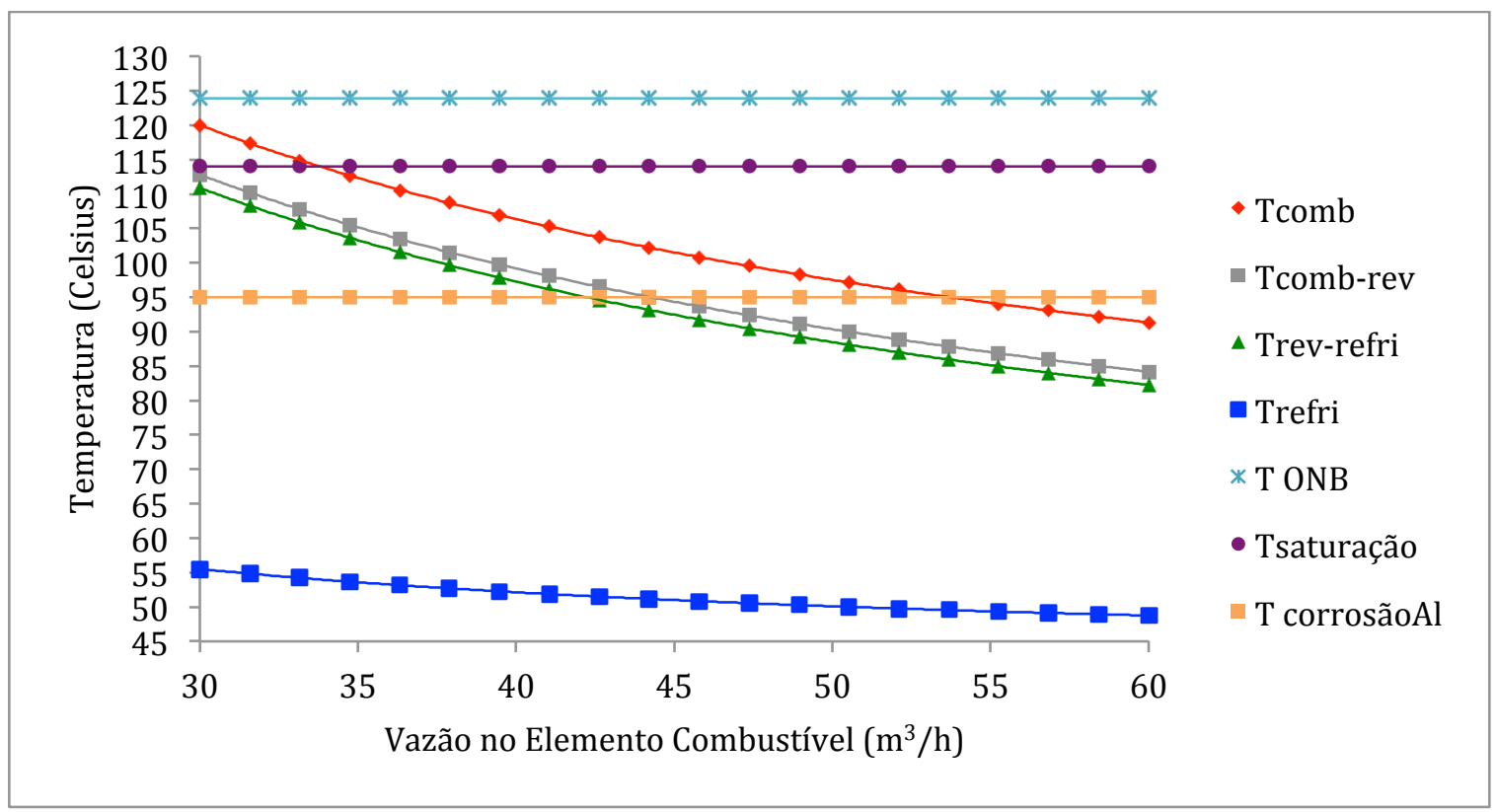

Figura 34 - Núcleo 6: Perfil de temperatura. 


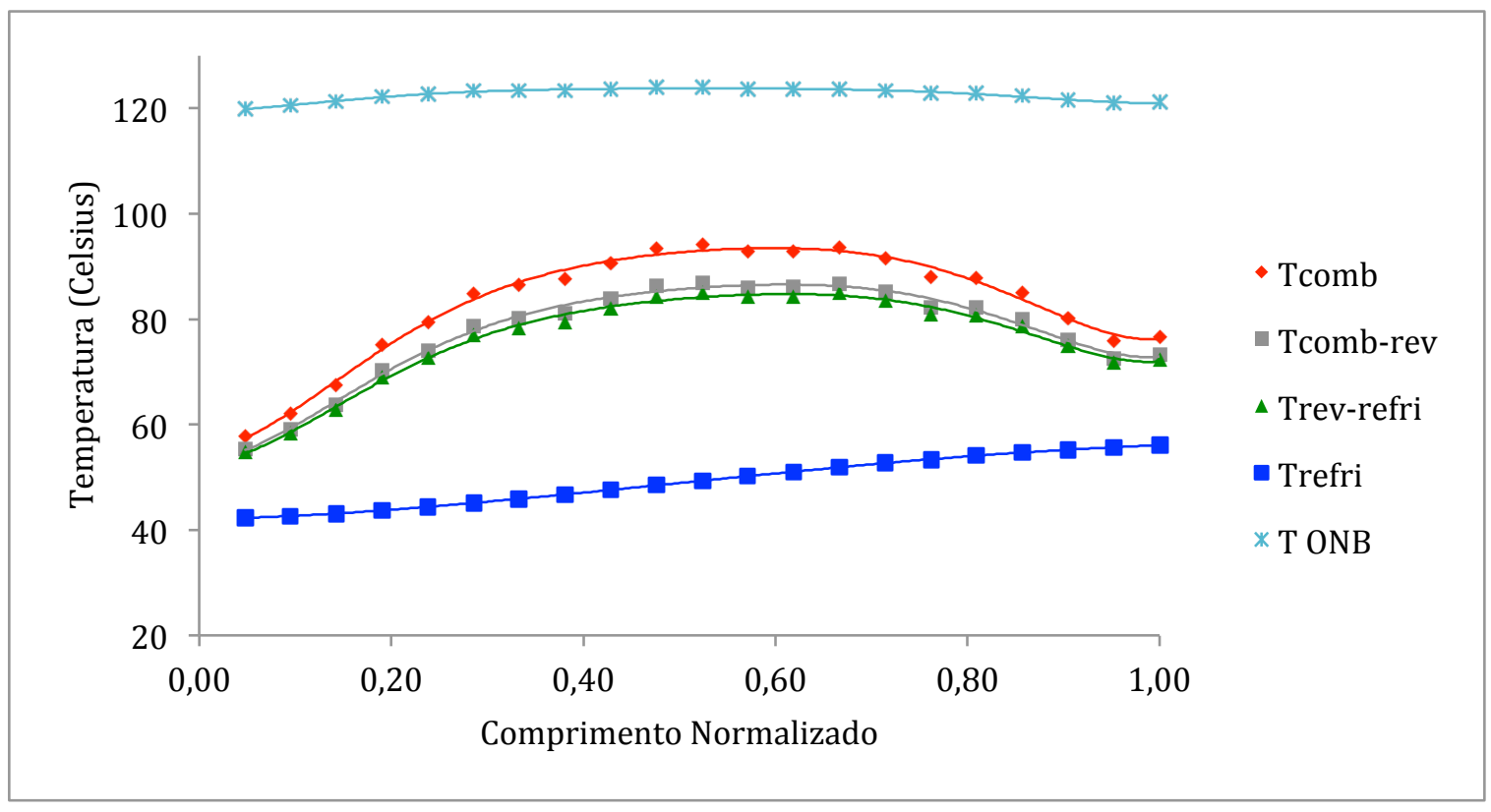

Figura 35 - Núcleo 6: Perfil de temperatura. Vazão 55 m³/h.

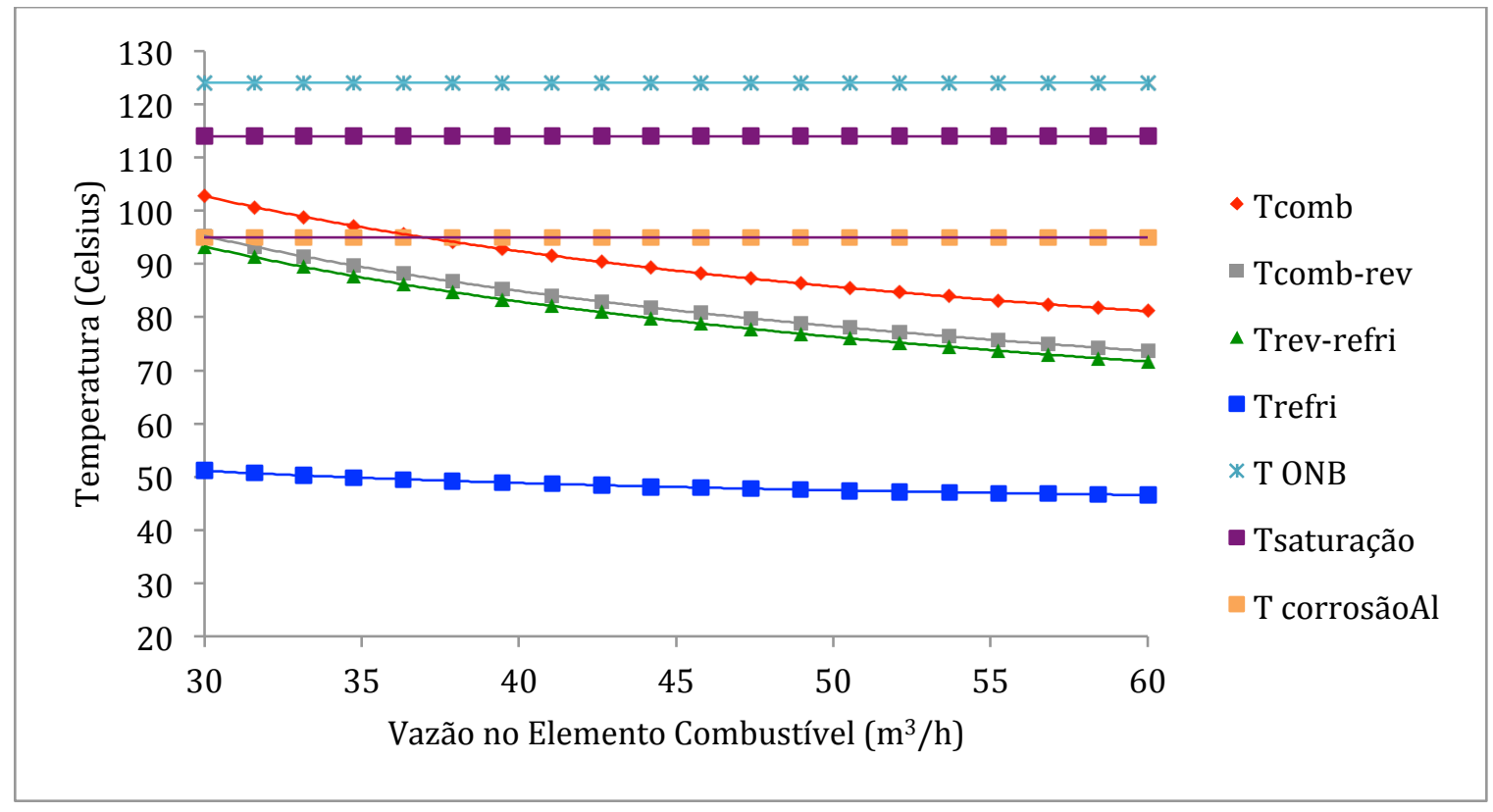

Figura 36 - Núcleo 7: Perfil de temperatura. 


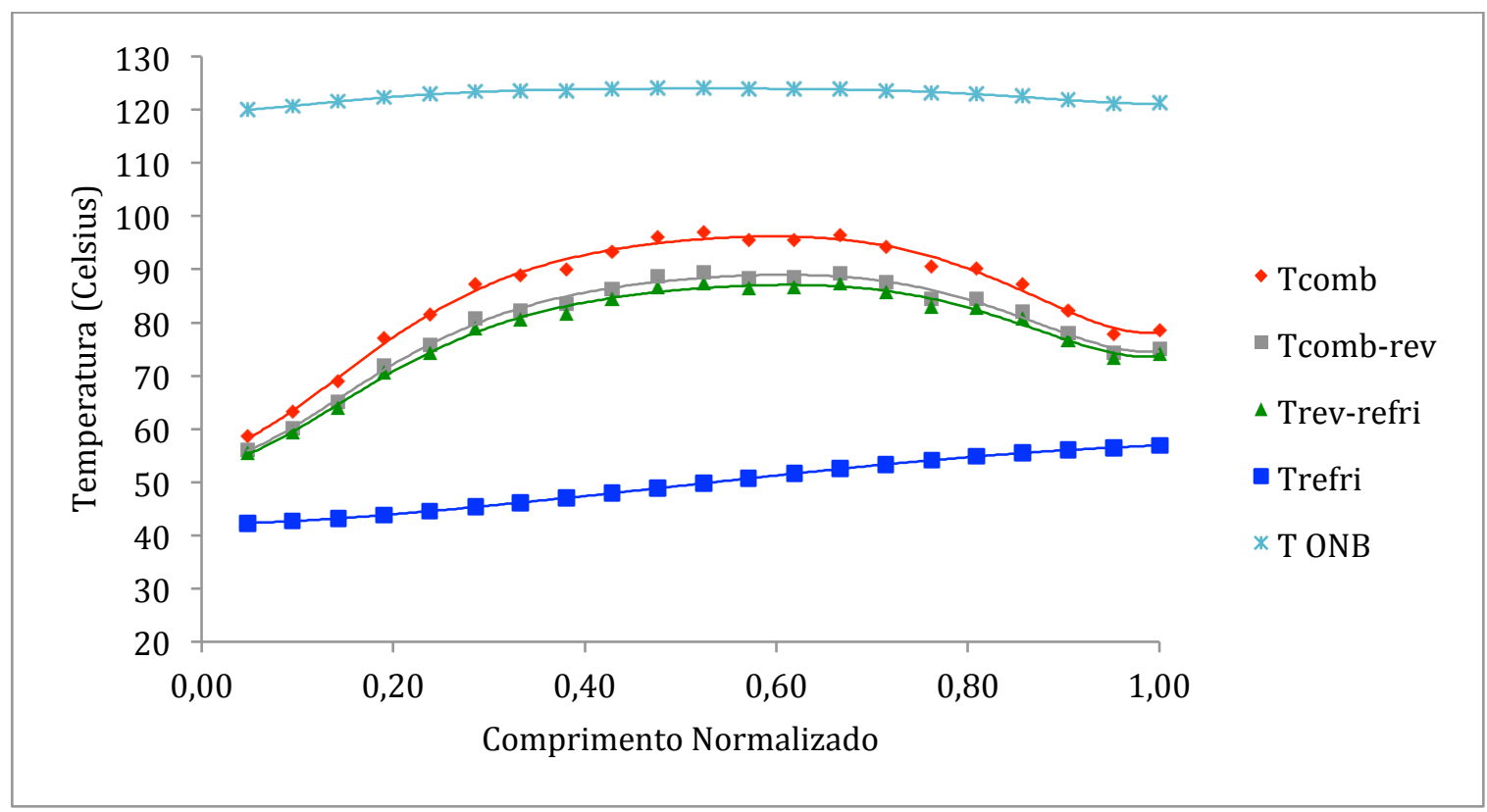

Figura 37 - Núcleo 7: Perfil de temperatura. Vazão 35 m³/h.

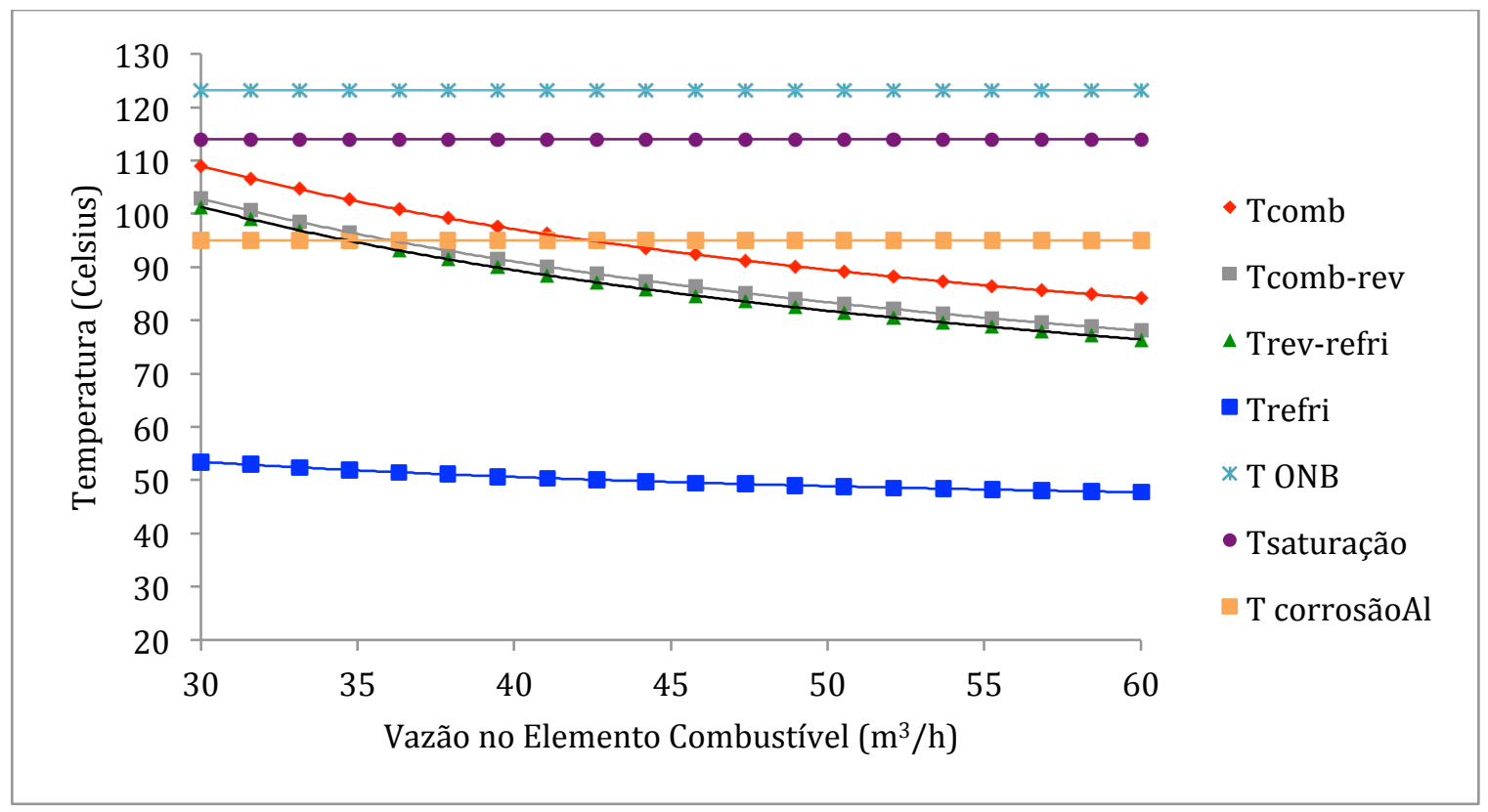

Figura 38 - Núcleo 8: Perfil de temperatura. 


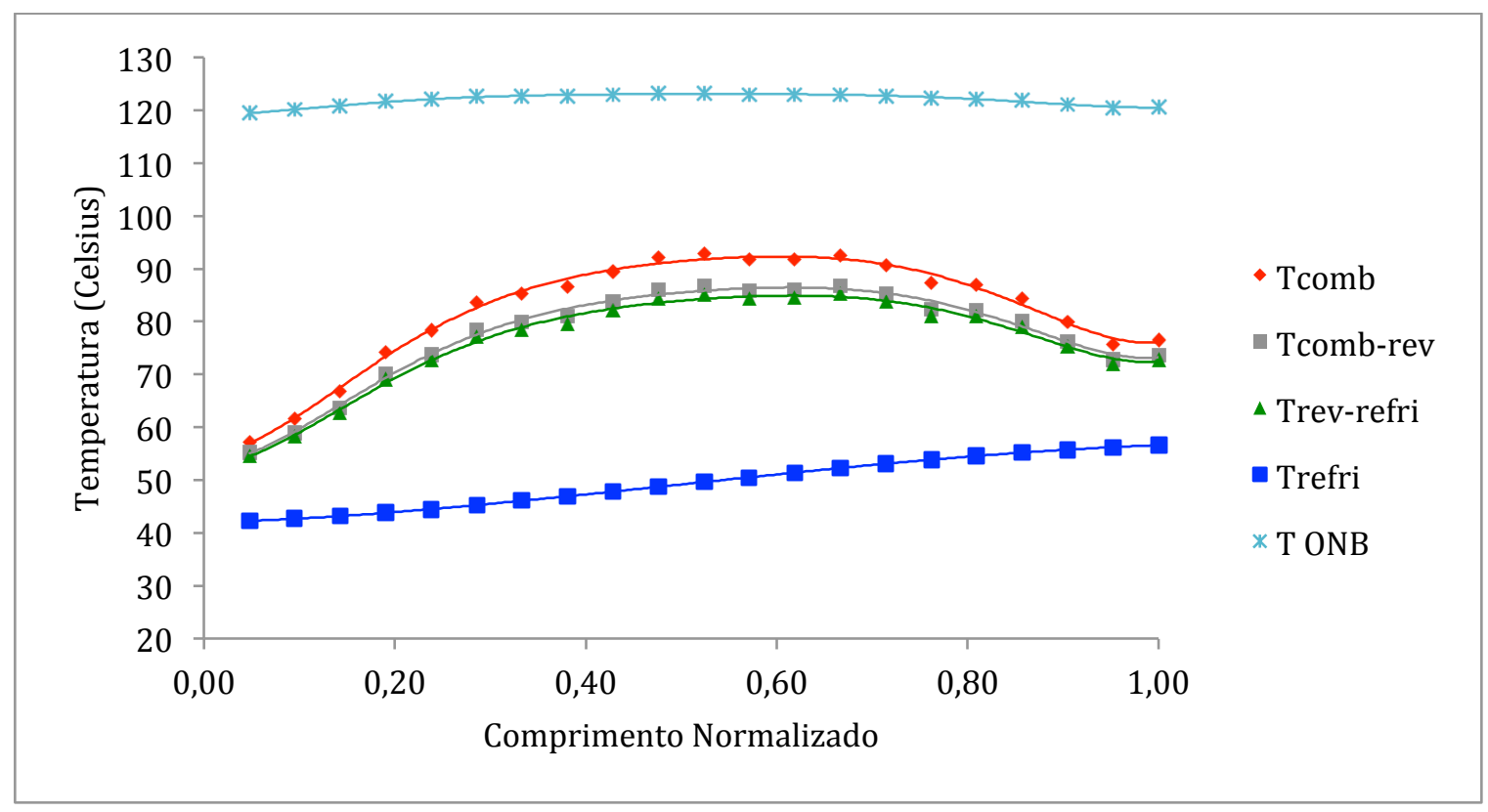

Figura 39 - Núcleo 8: Perfil de temperatura. Vazão $45 \mathrm{~m}^{3} / \mathrm{h}$.

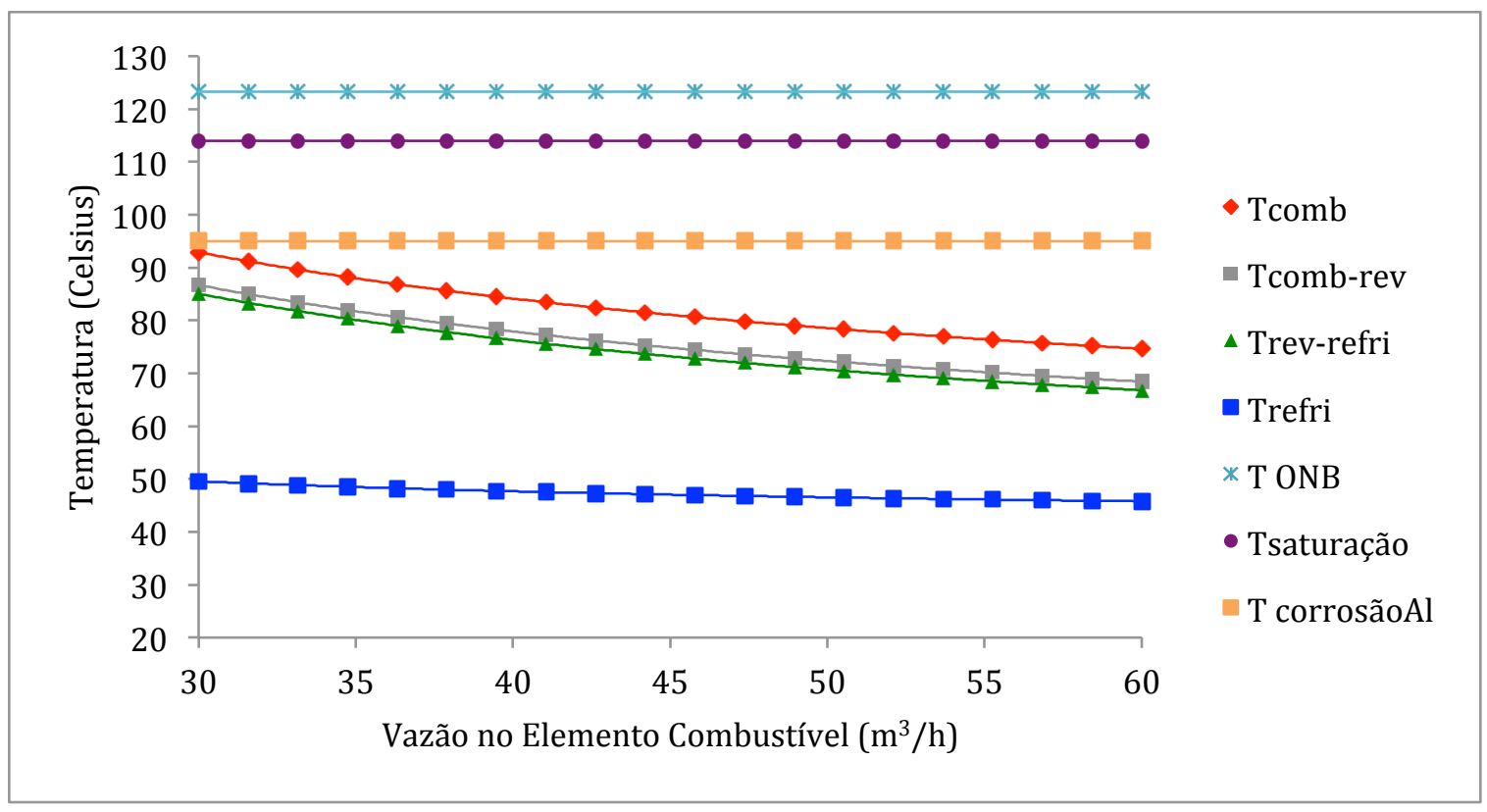

Figura 40 - Núcleo 8*: Perfil de temperatura. 


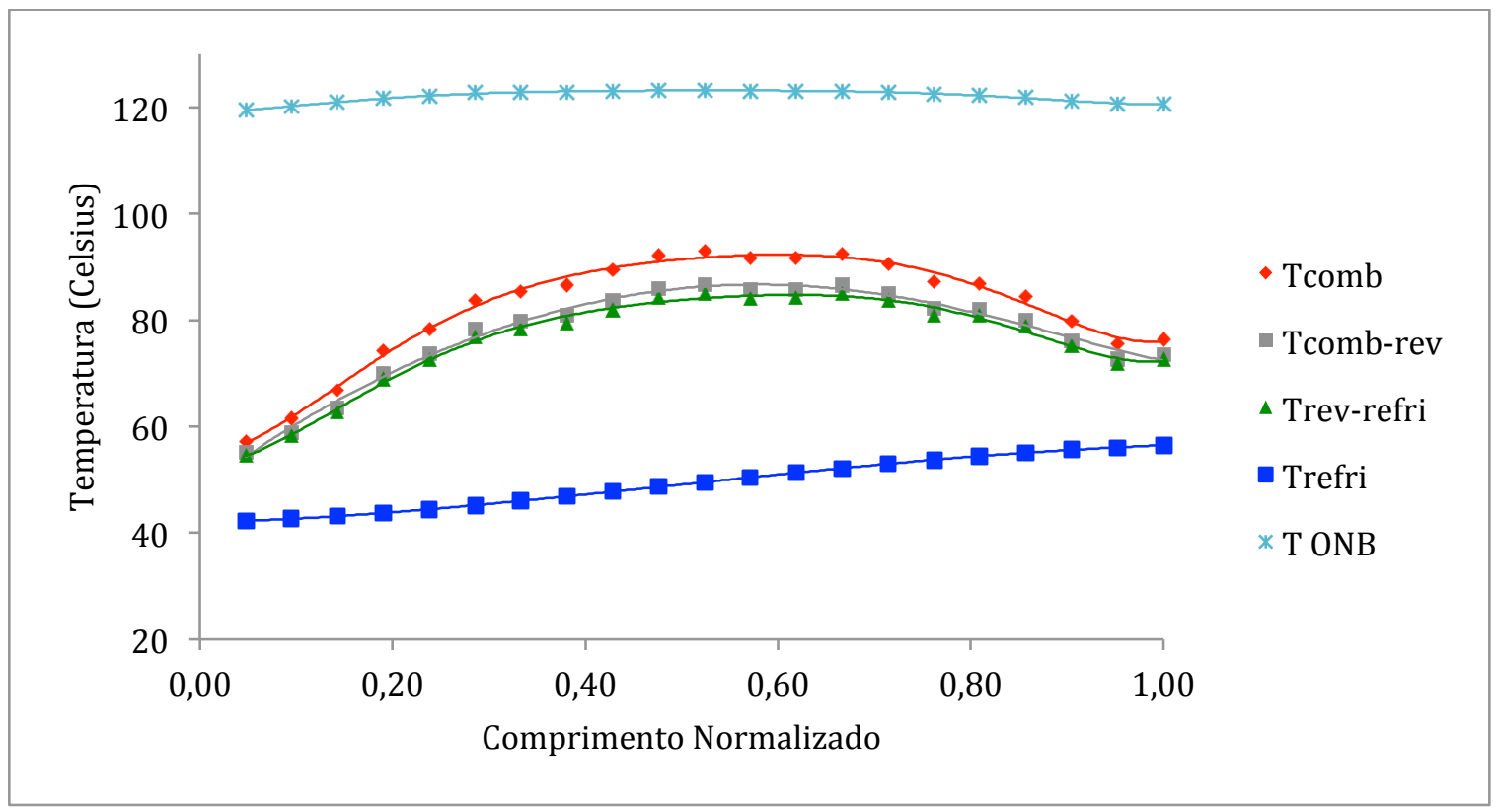

Figura 41 - Núcleo 8*: Perfil de temperatura. Vazão $30 \mathrm{~m}^{3} / \mathrm{h}$.

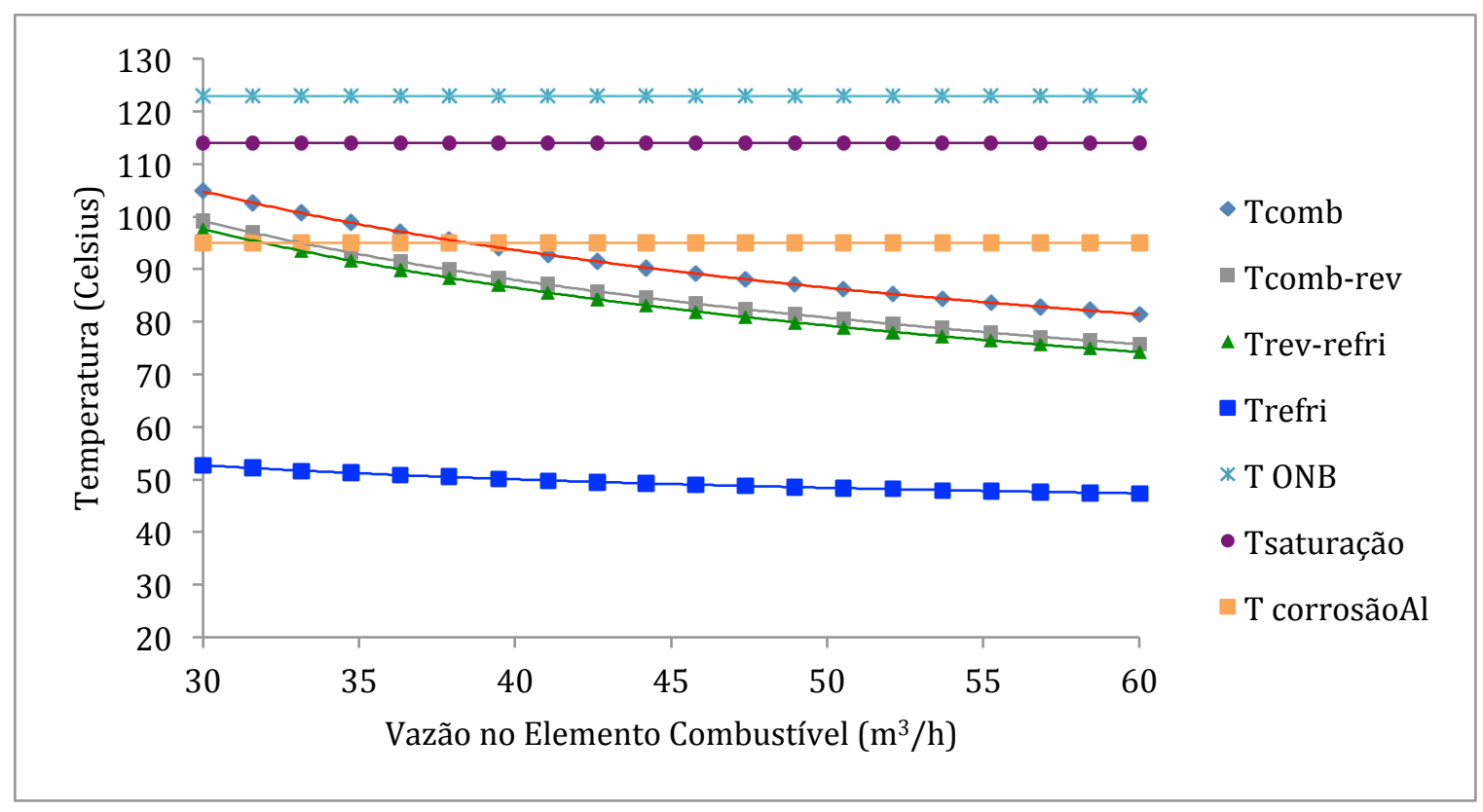

Figura 42 - Núcleo 9: Perfil de temperatura. 


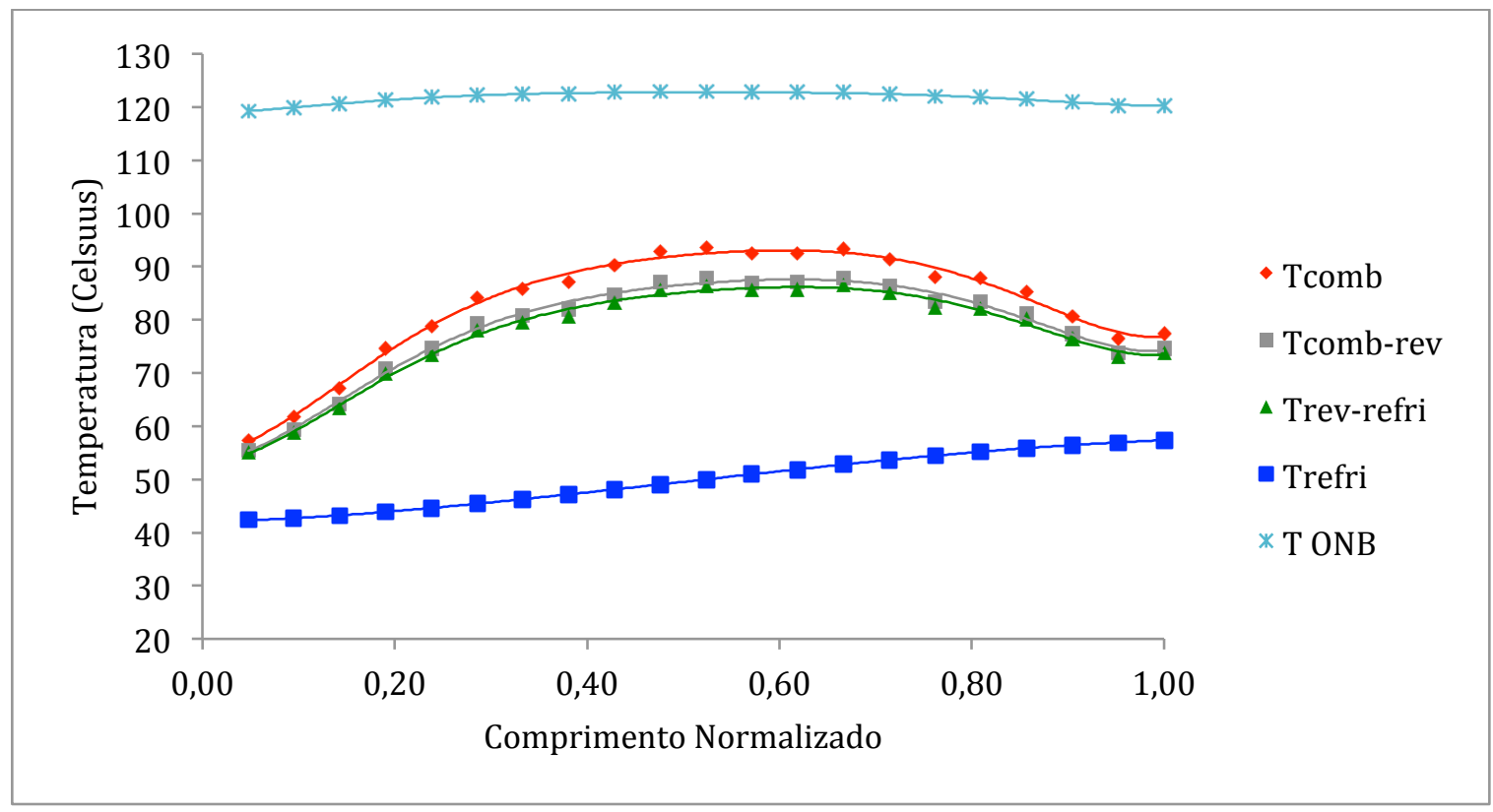

Figura 43 - Núcleo 9: Perfil de temperatura. Vazão $40 \mathrm{~m}^{3} / \mathrm{h}$.

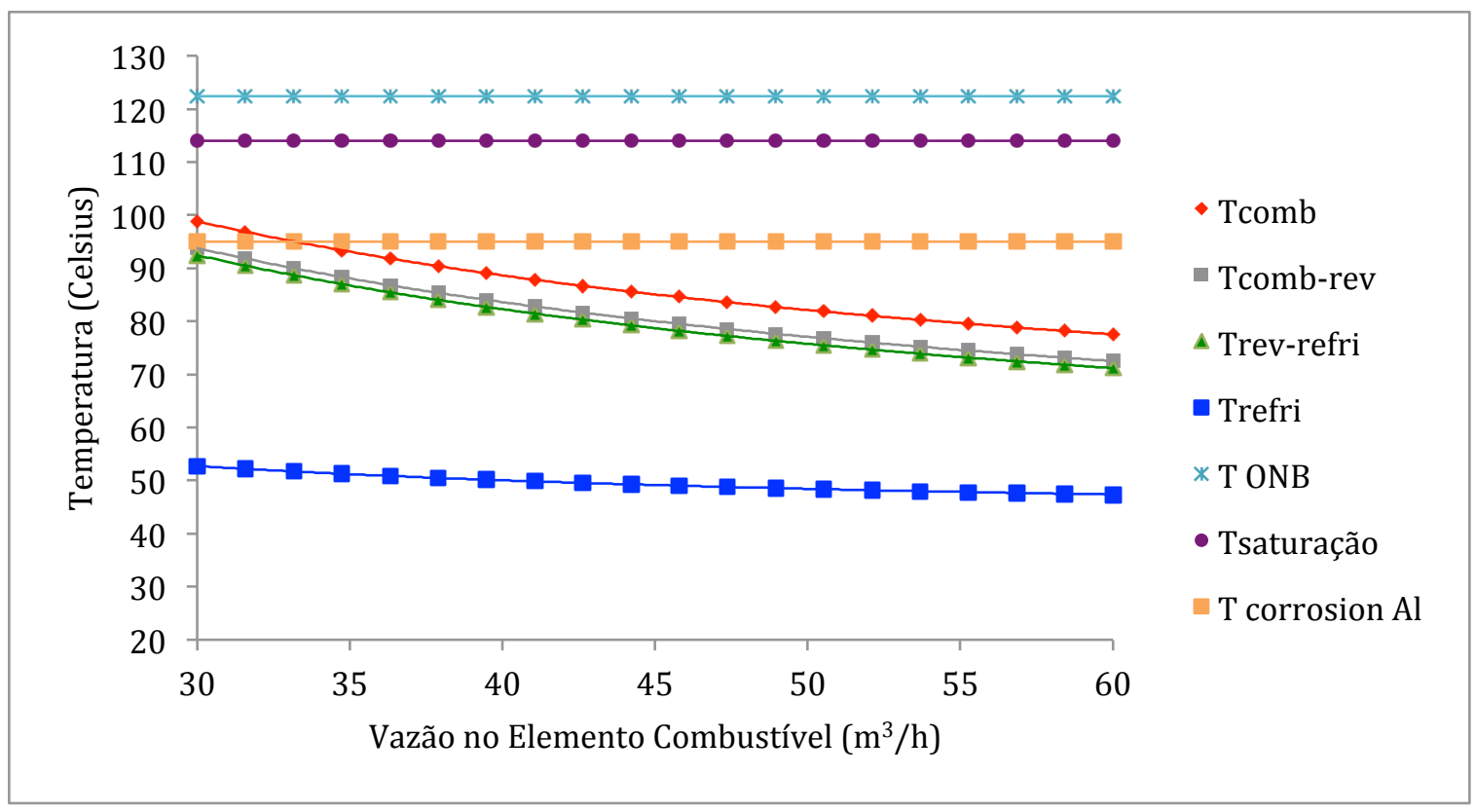

Figura 44 - Núcleo 10: Perfil de temperatura. 


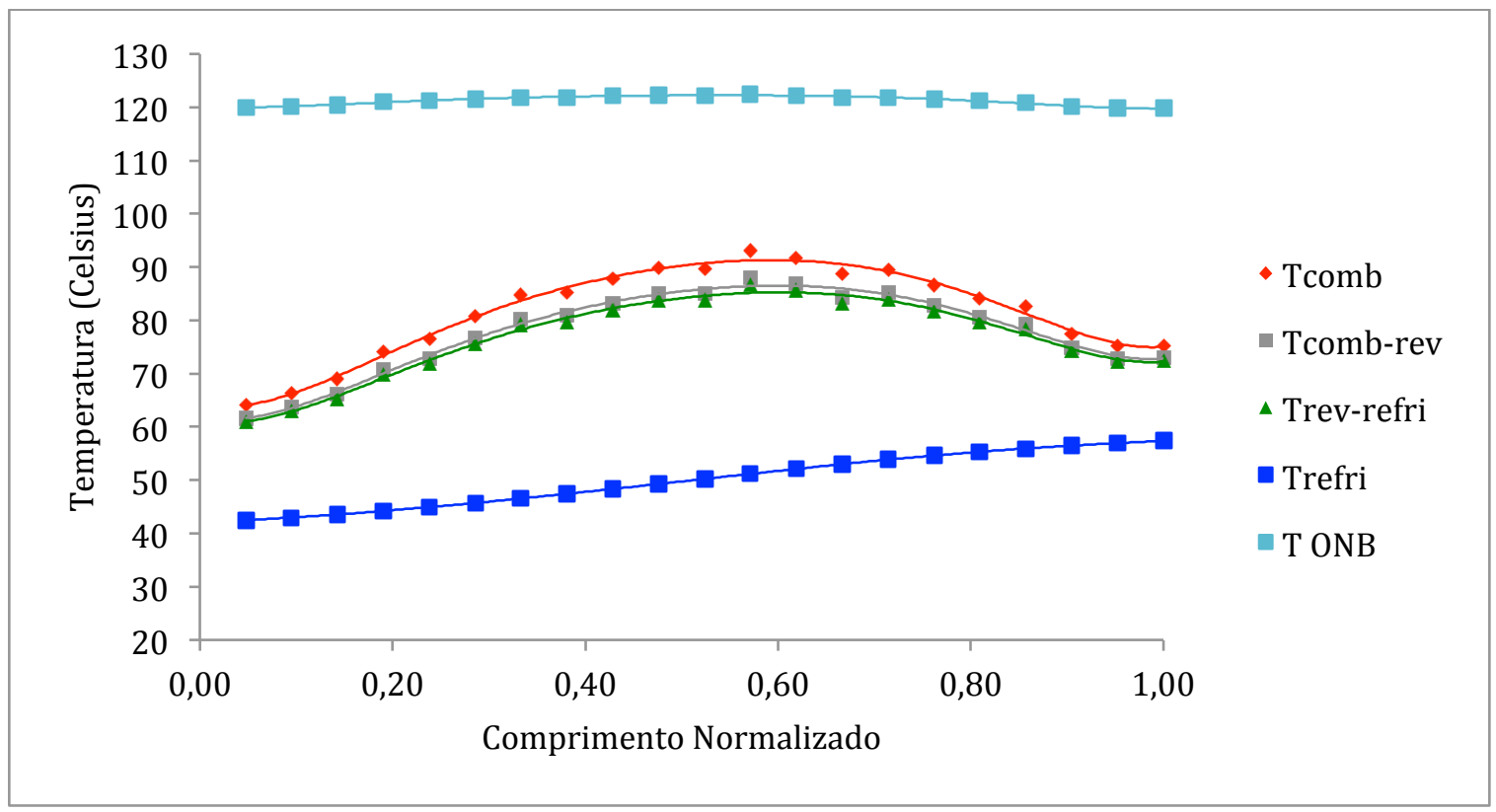

Figura 45 - Núcleo 10: Perfil de temperatura. Vazão $35 \mathrm{~m}^{3} / \mathrm{h}$.

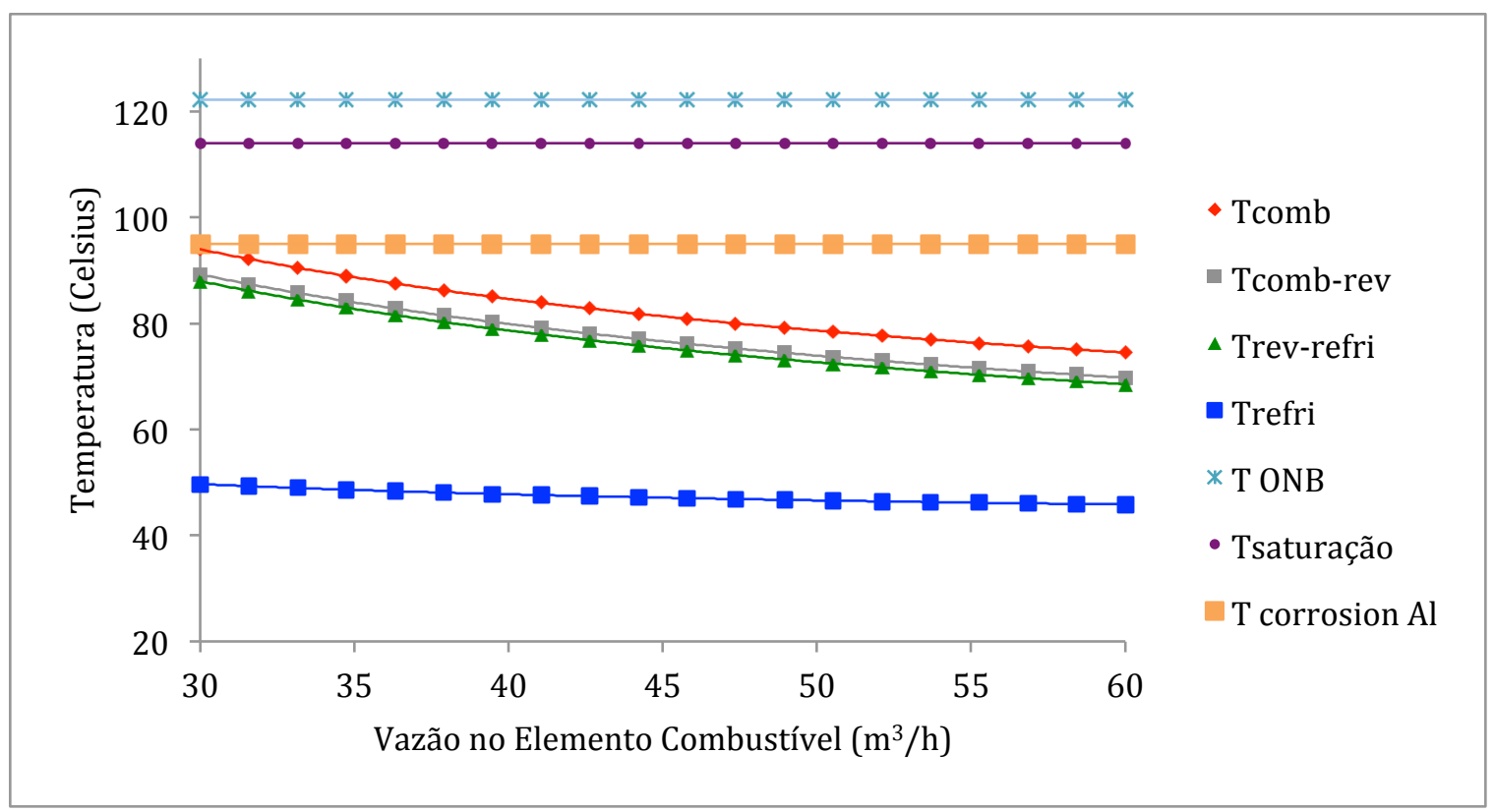

Figura 46 - Núcleo 12: Perfil de temperatura. 


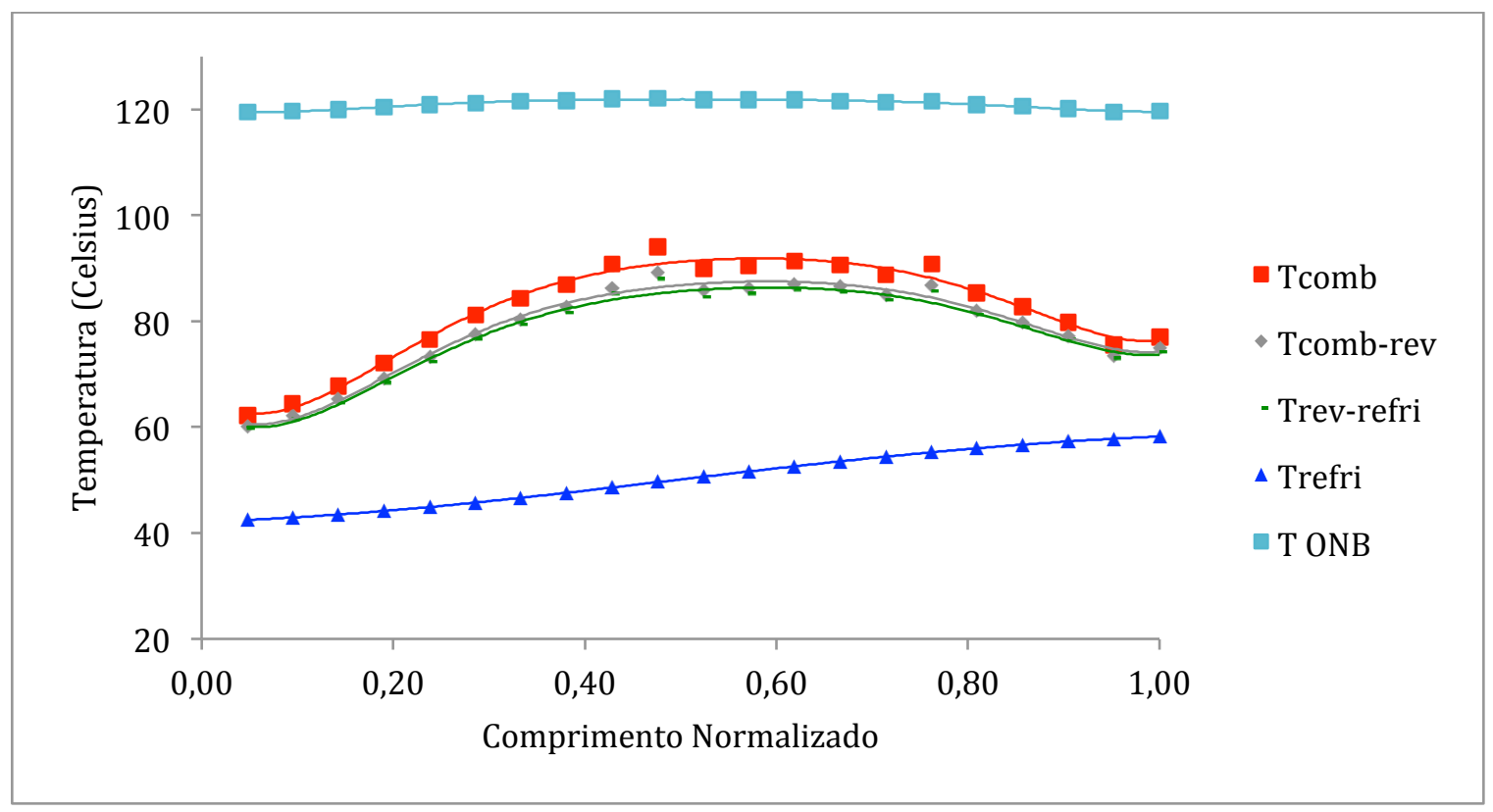

Figura 47 - Núcleo 12: Perfil de temperatura. Vazão $30 \mathrm{~m}^{3} / \mathrm{h}$.

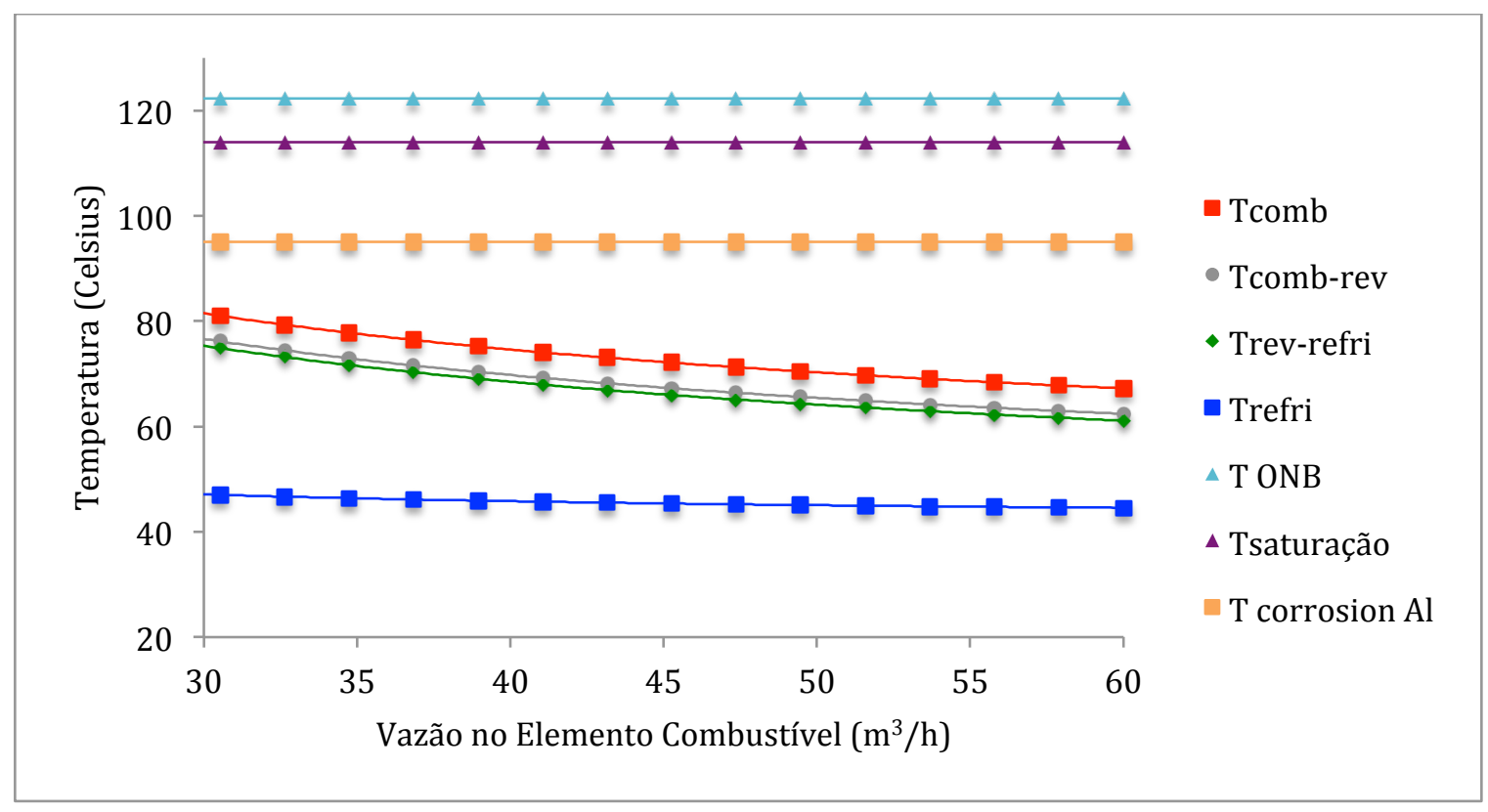

Figura 48 - Núcleo 12*: Perfil de temperatura. 


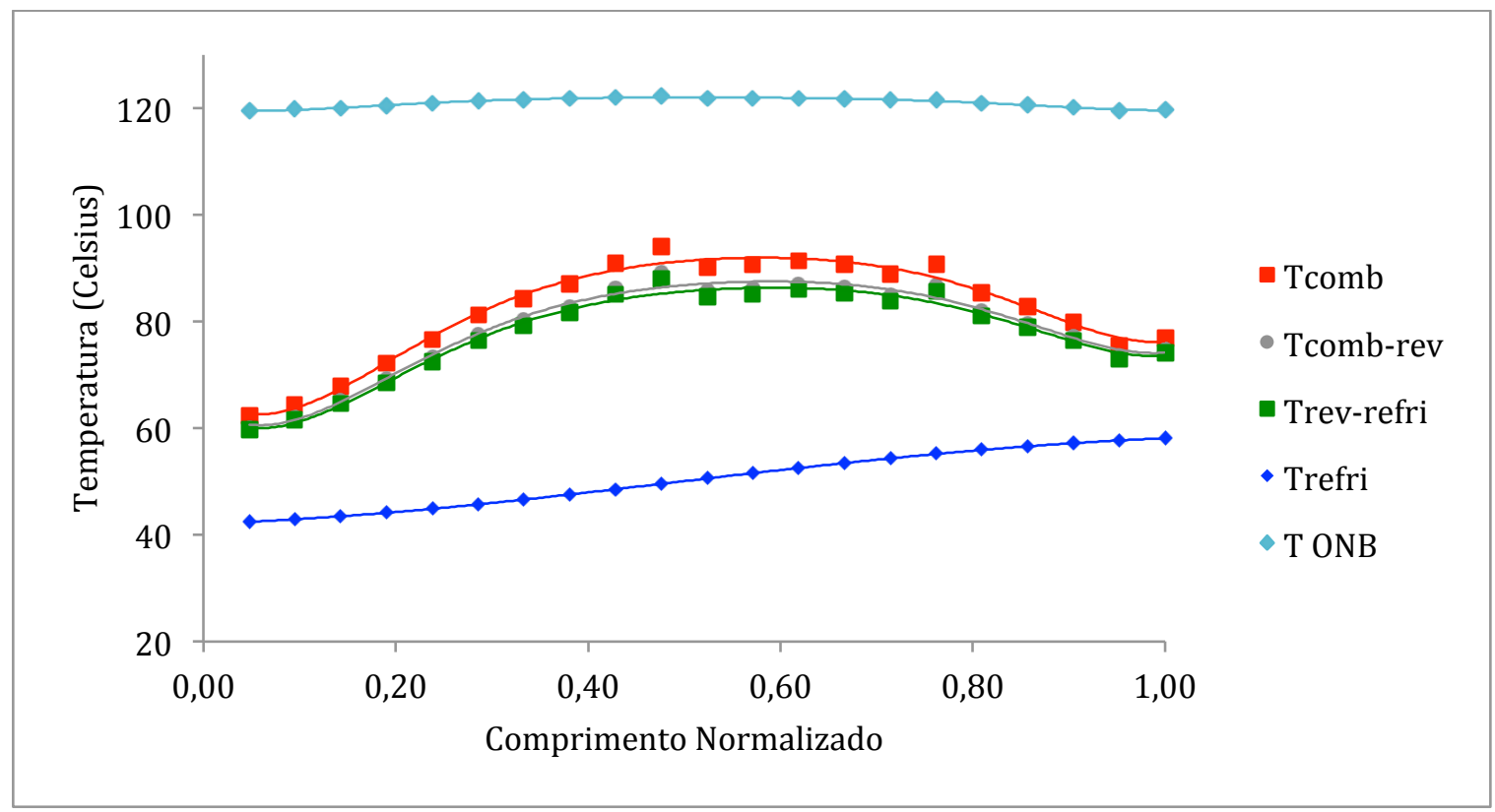

Figura 49 - Núcleo 12*: Perfil de temperatura. Vazão 20 m³/h.

A Tabela 5 apresenta os dados geométricos dos canais de resfriamento dos elementos combustíveis, assim como a pressão de operação e a temperatura de entrada do refrigerante.

Tabela 5 - Geometria dos elementos combustíveis, pressão de operação e temperatura de entrada do refrigerante.

\begin{tabular}{|cc|}
\hline Largura do Canal de Resfriamento & $67,1 \mathrm{~mm}$ \\
\hline Largura Ativa da Placa Combustível & $62,0 \mathrm{~mm}$ \\
\hline Espessura do Canal & $2,89 \mathrm{~mm}$ \\
\hline Espessura da placa combustível & $1,52 \mathrm{~mm}$ \\
\hline Espessura do Combustível & $0,80 \mathrm{~mm}$ \\
\hline Espessura do Revestimento & $0,38 \mathrm{~mm}$ \\
\hline Altura Total da Placa & $625 \mathrm{~mm}$ \\
\hline Altura Ativa da Placa & $600 \mathrm{~mm}$ \\
\hline Refrigerante & Água Leve $\left(42^{\circ} \mathrm{C}\right)^{*}$ \\
\hline Pressão de Operação & $1,6 \mathrm{bar}$ \\
\hline
\end{tabular}




\subsection{5 - Cálculo da Velocidade Crítica de Escoamento}

Vários fatores ao longo da fabricação de um elemento combustível podem contribuir para que não haja um paralelismo perfeito entre as placas combustíveis que o compõem.

Dessa forma, alguns canais podem possuir dimensões menores do que os demais. Num estreitamento de canal ocorre um aumento da velocidade do fluido refrigerante e uma consequente diminuição da pressão estática.

Pela equação de Bernoulli, sabe-se que o diferencial de pressão é proporcional ao quadrado da velocidade. A velocidade do fluido refrigerante que torna o gradiente de pressão da ordem da carga crítica de flambagem da placa (condição na qual a placa combustível começa a encurvar) é denominada velocidade crítica (veja Fig. 51 para entender no caso mecânico).

Considerando a situação na qual os desvios nas placas adjacentes ocorram em sentidos opostos (Fig. 52), haverá um estreitamento no canal de escoamento em relação a sua dimensão original, resultando em um aumento da velocidade de escoamento na seção onde ocorre o enforcamento (V) e uma redução na velocidade de escoamento (V') nas seções adjacentes simetricamente opostas.

Dependendo do diferencial das velocidades de escoamento entre as duas placas, surgirá um gradiente de pressão suficiente para levá-las a um certo nível de flambagem e aumentar ainda mais esse estrangulamento (Fig. 53).

De acordo com a magnitude da flambagem, poderá ocorrer um superaquecimento localizado dessas placas devido à redução da vazão de refrigerante disponível para troca térmica no canal de resfriamento em questão.

A expressão matemática para o cálculo dessa grandeza, a velocidade crítica ou máxima (Eq. 13), foi derivada por Miller [29] e é baseada nas interações entre os seguintes fatores: 
- Áreas transversais dos canais de resfriamento;

- Velocidades do refrigerante;

- Pressões em dois canais adjacentes.

Em um projeto, recomenda-se que a velocidade do refrigerante seja limitada a dois terços $(2 / 3)$ da velocidade crítica [21].

$$
V_{\text {Crítica }} \leq \frac{2}{3} V_{\text {Máxima }}=\frac{2}{3}\left[\frac{1,5 \times 10^{6} E\left(e_{p}{ }^{3}-e_{c e r n}{ }^{3}\right) e_{c}}{\rho L_{c}^{4}\left(1-v^{2}\right)}\right]^{1 / 2}
$$

onde $E$ é o módulo de elasticidade de Young da placa, $e_{p}$ a espessura da placa combustível (m), $e_{\text {cern }}$ a espessura do cerne (m), $e_{c}$ a espessura do canal de resfriamento (m), $\rho$ a densidade do fluido $\left(\mathrm{Kg} / \mathrm{m}^{3}\right), L_{c}$ a largura do canal $(\mathrm{m})$ e $v$, a razão de Poisson.

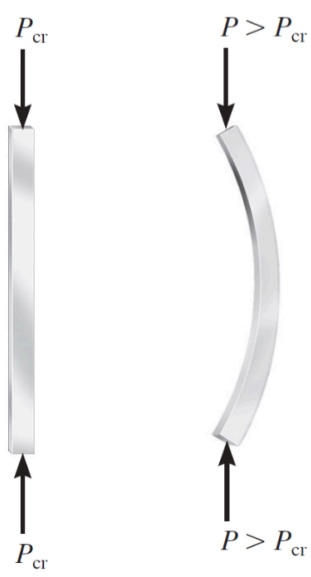

Figura 50 - Esquema de duas placas combustíveis sujeitas a condições diferentes de carga com a existência do fenômeno de flambagem no segundo caso (Mecânico).

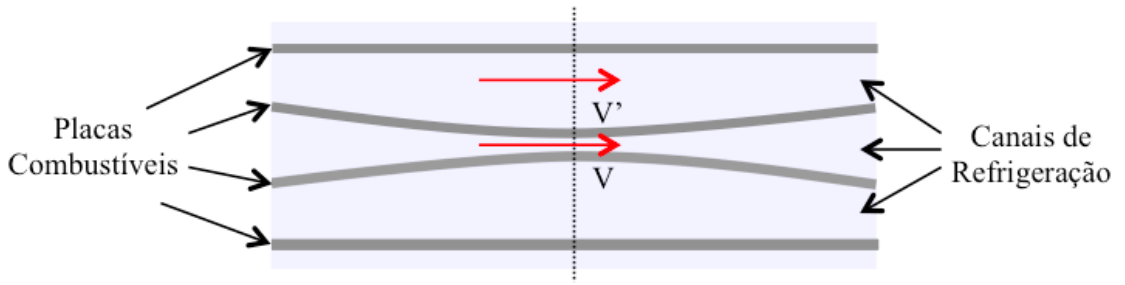

Figura 51 - Flambagem promovida por um gradiente de pressão via diferencial de velocidades de escoamento entre duas placas adjacentes. 


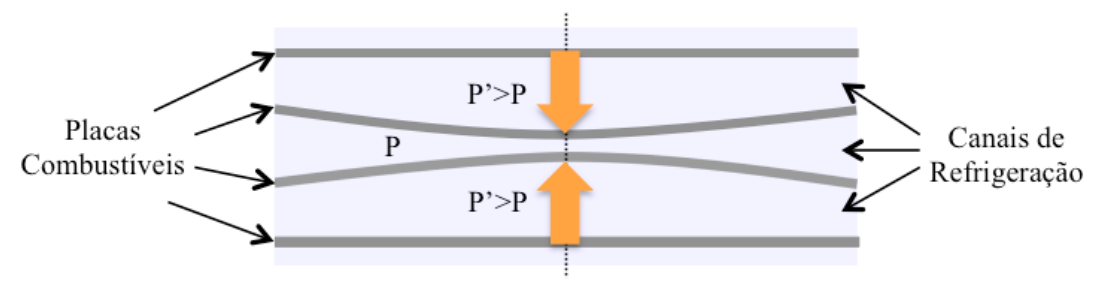

Figura 52 - Aumento na flambagem devido ao gradiente de pressão.

A Tabela 6 ilustra as velocidades nos canais de refrigerações em cada configuração comparados com a velocidade Crítica, determinada pela Eq. 13, que está inserida dentro do modelo térmico MTRCR-IEAR1.

Tabela 6 - Velocidades nos canais de resfriamento e a velocidade crítica permitida para cada nova configuração.

\begin{tabular}{|c|c|c|c|}
\hline Núcleo & $\begin{array}{c}\text { Velocidade } \\
(\mathrm{m} / \mathrm{s})\end{array}$ & $\begin{array}{c}\text { Velocidade Crítica } \\
(\mathrm{m} / \mathrm{s})\end{array}$ & $\%$ \\
\hline 5 & 5,06 & 14,91 & 33,91 \\
6 & 4,63 & 14,91 & 31,08 \\
7 & 2,95 & 14,91 & 19,78 \\
8 & 3,79 & 14,91 & 25,43 \\
$8^{*}$ & 2,53 & 14,91 & 16,96 \\
9 & 3,37 & 14,91 & 22,60 \\
10 & 2,95 & 14,91 & 19,78 \\
12 & 2,53 & 14,91 & 16,96 \\
$12 *$ & 1,69 & 14,91 & 11,30 \\
\hline
\end{tabular}




\section{Novos Núcleos para o Reator IEA-R1: Verificação do Coeficiente de Temperatura e a Queima dos Núcleos}

Neste capítulo, são desenvolvidos alguns aspectos relevantes não cobertos pela análise termo-hidráulica, mas de suma importância para o desenvolvimento do projeto de um reator nuclear. Assim como as margens de segurança apresentadas e calculadas no capítulo anterior, alguns parâmetros são importantes para assegurar o bom funcionamento de um reator. Os seguintes itens serão abordados neste capítulo:

- Verificação dos coeficientes de reatividade de temperatura $\alpha_{\text {ISO }}$;

- Queima dos novos núcleos;

\section{1 - Verificação do Coeficiente de Reatividade de Temperatura $\overline{\boldsymbol{\alpha}}_{T}$}

O coeficiente de reatividade de temperatura (ou também chamado de coeficiente de temperatura) é definido pela seguinte expressão (Eq. 14):

$$
\text { Coeficiente de Temperatura }=\alpha_{T}=\frac{\partial \rho}{\partial T}
$$

onde $T$ é a temperatura e $\rho$, a reatividade (ou excesso de reatividade). O coeficiente de temperatura pode ser negativo (caso desejável) ou positivo, indicando que a reatividade pode diminuir ou aumentar com o aumento da temperatura. Entretanto, como o aumento da temperatura em um reator geralmente implica em um aumento do calor liberado, pode-se criar um cenário de acidente caso esse parâmetro não seja bem controlado e estudado. As mudanças de temperatura no reator podem modificar a reatividade de três formas distintas: 
1. Alterando a energia média dos nêutrons térmicos no reator térmico, sem alteração dos nêutrons rápidos;

2. Alterando as densidades dos componentes do reator nuclear;

3. Alterando o tamanho ou volume do núcleo.

Devido a essa divisão, divide-se também, matematicamente, o coeficiente de temperatura em três partes (Eq. 15):

- Coeficiente nuclear;

- Coeficiente de densidade;

- Coeficiente de volume.

$$
\alpha_{T}=\frac{\partial \rho}{\partial T}=\frac{\partial \rho_{n}}{\partial T}+\frac{\partial \rho_{d}}{\partial T}+\frac{\partial \rho_{V}}{\partial T}
$$

onde os índices $n, d$, e $V$ denotam nuclear, densidade e volume, respectivamente.

O coeficiente nuclear surge principalmente através do efeito da temperatura no comprimento térmico de difusão $L=\sqrt{D / \Sigma_{a}}$ num reator térmico, pois a seção de choque macroscópica de absorção $\Sigma_{a}$, depende da temperatura. Esse coeficiente é proporcional a $L^{2}$ [30] e é geralmente negativo. Entretanto, num reator rápido resfriado, por exemplo, a expansão do sódio com a temperatura reduz sua ligeira capacidade de moderação e, por consequência, aumenta a energia média do nêutron, provocando um aumento no fator de fissão ( $)$ e, consequentemente, $k_{\infty}$, implicando num coeficiente nuclear positivo.

$\mathrm{O}$ coeficiente de densidade surge devido à mudança de densidades dos componentes do núcleo do reator com a mudança na temperatura. Essa mudança induz alterações na reatividade através da mudança das densidades dos materiais que constituem o núcleo, como o moderador em reatores térmicos, combustíveis, etc.

O aumento da temperatura reduz essas densidades e as seções de choque macroscópicas de absorção e espalhamento. Isso aumenta o livre caminho médio e por consequência o escape de nêutrons do núcleo. 
O coeficiente de densidade é proporcional a um coeficiente linear médio de expansão térmica dos materiais do núcleo e é geralmente negativo. Em alguns casos, esse coeficiente pode ser positivo, por exemplo, em reatores moderados à água leve com grande razão moderador/combustível.

Por fim, o coeficiente de volume ocorre devido a mudanças no tamanho do núcleo do reator e consequentemente do buckling [31] com a temperatura. Esse coeficiente é também proporcional a um coeficiente linear médio de expansão térmica dos materiais do núcleo e vaso do reator. Sua ocorrência é geralmente positiva e apresenta, dentre os três tipos de coeficientes de temperatura, o menor valor numérico associado.

De forma geral, o coeficiente de temperatura é, na maioria dos casos, negativo e esse é o resultado desejado para evitar acidentes e exercer uma operação segura do reator nuclear. Para os núcleos estudados, foram calculados os coeficientes de temperatura da seguinte maneira:

1. Calculou-se o excesso de reatividade $\rho$ com a temperatura fixa em $27^{\circ} \mathrm{C}(300 \mathrm{~K})$ para os núcleos isotérmicos, ou seja, considerando todas as partes do mesmo apresentando esse valor para a temperatura;

2. Calculou-se o excesso de reatividade $\rho$ com a temperatura fixa em $54^{\circ} \mathrm{C}(327 \mathrm{~K})$;

3. Determinou-se o coeficiente de temperatura médio, a razão entre a variação do excesso de reatividade e a variação de temperatura (Eq. 16).

$$
\overline{\alpha_{T}}=\frac{\rho_{54^{\circ} \mathrm{C}}-\rho_{27^{\circ} \mathrm{C}}}{\Delta T}
$$

Os resultados dessa análise estão dispostos na Tabela 7, ressaltando que os núcleos 12 e $12 *$ foram excluídos dessa etapa pois decidiu-se optar por manter as atenções em núcleos menores núcleos menores, com valores de reatividade mais baixos quando todas as barras estão inseridas no mesmo, critério este, sustentado pelo fato de que vários materiais presentes no núcleo podem afetar o fator de multiplicação, fazendo com que os valores apresentados na Tabela 1 sofram variações significativas. 
Tabela 7 - Cálculo do coeficiente de temperatura $\left(\overline{\alpha_{T}}\right)$.

\begin{tabular}{|c|c|c|c|c|c|c|c|c|}
\cline { 2 - 8 } \multicolumn{1}{c|}{} & \multicolumn{2}{c|}{$\mathrm{T}=300 \mathrm{~K}$} & SDEV & \multicolumn{2}{c|}{$\mathrm{T}=327 \mathrm{~K}$} & SDEV & $\overline{\alpha_{T}}$ & \multirow{2}{*}{ SDEV } \\
\cline { 2 - 8 } \multicolumn{1}{c|}{} & Keff & $\rho$ & $(\mathrm{pcm})$ & Keff & $\rho$ & $(\mathrm{pcm})$ & $\left(\mathrm{pcm} /{ }^{\circ} \mathrm{C}\right)$ & $\left(\mathrm{pcm} /{ }^{\circ} \mathrm{C}\right)$ \\
\hline Núcleo 5 & 1,00765 & 759 & 12 & 1,00426 & 424 & 13 & $-12,41$ & 0,76 \\
Núcleo 6 & 1,02510 & 2449 & 12 & 1,02193 & 2146 & 12 & $-11,21$ & 0,76 \\
Núcleo 7 & 1,03441 & 3327 & 12 & 1,03072 & 2980 & 11 & $-12,82$ & 0,72 \\
Núcleo 8 & 1,06969 & 6515 & 11 & 1,06612 & 6202 & 11 & $-11,59$ & 0,67 \\
Núcleo 8* & 1,08975 & 8236 & 11 & 1,08668 & 7977 & 11 & $-9,60$ & 0,68 \\
Núcleo 9 & 1,09694 & 8837 & 11 & 1,09358 & 8557 & 11 & $-10,37$ & 0,67 \\
Núcleo 10 & 1,10154 & 9218 & 11 & 1,09822 & 8944 & 11 & $-10,16$ & 0,67 \\
\hline
\end{tabular}

\section{2 - Queima dos Novos Núcleos}

Outro aspecto importante para o projeto de um novo núcleo do reator IEA-R1 é saber como os materiais e elementos que o compõem se comportam com o decorrer do tempo. Durante o funcionamento de um reator nuclear, há mudanças isotópicas consideráveis nos materiais combustíveis provenientes da fissão do U-235. Essas mudanças ocorrem no tempo e também no espaço. Três particularidades referentes à queima (burnup) são de grande interesse e são abordadas no presente estudo:

- Variação do Fator de multiplicação com o tempo;

- A depleção do combustível (queima média total no combustível , U-235);

- Venenos queimáveis (Xe-135).

Ao longo do ciclo de um reator nuclear, os nuclídeos físseis são consumidos através da fissão e cerca de duzentos produtos de fissão são formados, alguns diretamente e outros via decaimento radioativo. Parte desses produtos de fissão possuem alta ou moderadamente alta seção de choque para captura de nêutrons, tendo consequentemente influência significativa na população dos mesmos (e na reatividade) em um dado sistema. Além disso, a conversão de nuclídeos férteis em físseis tem claramente um efeito importante na vida útil e controle do reator [32]. Dessa mesma forma, a captura radiativa de nêutrons por ambas espécies, férteis e físseis, levam à formação de nuclídeos como U-236, Pu-240, U-239, etc. Esses nuclídeos podem capturar nêutrons ou sofrerem decaimento beta, fazendo com que novos isótopos pesados (Tório, Protactínio, Urânio, Neptúnio, Plutônio, etc.) apareçam no combustível após um certo período de tempo (operação). 
Para reduzir o número de nuclídeos que necessitam ser incluídos no cálculo de queima e minimizar o tempo de cálculo, dois princípios básicos devem ser observados:

1. Os únicos produtos de fissão tratados de forma explícita são aqueles com elevadas seções de choque de captura. Na prática, para reatores térmicos, a maioria dos produtos de fissão são agrupados em uma ou duas classes para as quais são determinadas seções de choque médias. Xe-125 e Sm-149 são sempre considerados, individualmente, em reatores térmicos;

2. Qualquer nuclídeo com meia vida curta pode ser omitido do cálculo. Por exemplo, U-239, que possui meia vida de 23,5 minutos, não necessita ser considerado. Assim, os únicos nuclídeos geralmente tratados em cálculos de queima são: U-235, U-236 e U-238; Pu-239, Pu-240, Pu-241 e Pu-242 em reatores a Urânio natural levemente enriquecidos em U-235 como combustível; U-233, U-234, U-235, U-236, Pa-233, Th-232 em reatores contendo Th-232 como material fértil.

Os nuclídeos férteis e físseis, produtos de fissão, isótopos pesados e venenos queimáveis podem ser tratados de um único ponto de vista (matemático) no cálculo da queima. Seja $N_{i}(\vec{r}, t)$ o número de núcleos por unidade de volume de um certo nuclídeo, indicado por "i”. Assim, a razão na qual $N_{i}$ (omite-se o argumento por mera conveniência) varia com o tempo é dada por:

$$
\frac{d N_{i}}{d t}=\text { Taxa de Formação - Taxa de Destruição - Taxa de Decaimento }
$$

Por simplicidade, os nuclídeos podem ser considerados como sendo formados e destruídos como somente resultado da fissão, captura de nêutrons e decaimento radioativo (beta negativo). As taxas da Eq. 3 podem ser expressas como mostrado a seguir.

Denota-se por $N_{i-1}$ a concentração de nuclídeos que podem ser convertidos em nuclídeos do tipo $i$ via captura de nêutrons; ou seja, se um nuclídeo possui massa e número atômico $(A, Z)$, então $i-1$ representa $(A-1, Z)$; a constante de decaimento para esses nuclídeos é representada como $\lambda_{i}$. 
Finalmente, seja $N_{j}$ a concentração de nuclídeos físseis e fissionáveis e $\gamma_{j i}(E)$ a probabilidade com que um nuclídeo do tipo $i$ seja formado como um produto de fissão por absorção de um nêutron de energia $E$ por um nuclídeo do tipo $j$. Se o nuclídeo do tipo $i$ não for produto de fissão, então $\gamma_{j i}=0$.

Com as definições anteriores, a Eq. 17 pode ser reescrita como

$$
\frac{d N_{i}}{d t}=\sum_{j} \overline{\gamma_{j i} \sigma_{f, j}} N_{f} \emptyset+\bar{\sigma}_{\gamma, i-1} N_{i-1} \emptyset+\lambda_{j} N_{j}-\bar{\sigma}_{f, i} N_{i} \emptyset-\bar{\sigma}_{\gamma, i} N_{i} \emptyset-\lambda_{i} N_{i}
$$

onde as quantidades com barras simplesmente significam que são grandezas médias. $O$ primeiro termo da direita, após o sinal de igualdade, é a taxa de formação de nuclídeos do tipo $i$, através da fissão de nuclídeos do tipo $j$,

$$
\overline{\gamma_{j i} \sigma_{f, j}} N_{f} \emptyset=\int_{0}^{\infty} \gamma_{j i}(E) \sigma_{f, j}(E) N_{j}(\vec{r}, t) \emptyset(\vec{r}, E, t) d E
$$

onde a seção de choque microscópica em questão, $\sigma_{f, j}(E)$, é a de fissão para núcleos do tipo $j$ e nêutrons de energia $E$, com o fluxo definido como

$$
\emptyset(\vec{r}, t)=\int_{0}^{\infty} \emptyset(\vec{r}, E, t) d E
$$

e pela Eq. 19,

$$
\overline{\gamma_{j i} \sigma_{f, j}}=\frac{\int_{0}^{\infty} \gamma_{j i}(E) \sigma_{f, j}(E) \emptyset(\vec{r}, E, t) d E}{\emptyset(\vec{r}, t)}
$$

Essa grandeza pode ser computada como função do espaço e do tempo, uma vez que a integral é somente na energia, conhecendo-se o fluxo de nêutrons, as seções de choque de fissão e as probabilidades de conversão do nuclídeo $j$ em $i$. Também não dependerá do tempo se o espectro de energia do nêutron não mudar. 
O segundo termo, Eq. 19, representa a taxa de formação de núcleos do tipo $i$ através da captura de nêutrons por núcleos do tipo $i-1$, assim,

$$
\bar{\sigma}_{\gamma, i-1} \emptyset=\int_{0}^{\infty} \sigma_{\gamma, i-1}(E) \emptyset(\vec{r}, E, t) d E
$$

onde a seção de choque em questão é a seção de choque microscópica de captura radiativa de núcleos do tipo $i-1$ e nêutrons de energia $E$.

O terceiro termo na Eq. 19 é a taxa de decaimento radioativo como resultado do qual os nuclídeos do tipo $i$ são formados e o quarto termo, a taxa de destruição dos nuclídeos tipo $i$ via fissão. Assim,

$$
\bar{\sigma}_{f, i} \emptyset=\int_{0}^{\infty} \sigma_{f, i}(E) \emptyset(\vec{r}, E, t) d E
$$

Por fim, o quinto termo é a taxa de perda dos núcleos do tipo $i$ como resultado da captura de nêutrons e é equivalente à Eq. 22, substituindo $i-1$ por $i$. O sexto e último termo é a taxa de decaimento radioativo de núcleos do tipo $i$.

Em geral, para cada ponto do reator tem-se uma Eq. 18 para cada tipo de nuclídeo, que deve ser analisado ao longo da queima do combustível. As equações diferenciais resultantes são acopladas através dos vários processos de criação e destruição de nuclídeos. Na prática, simplificações são feitas para facilitar o problema.

O método utilizado para solucionar essa equação, considerando os novos núcleos estudados, foi o método Monte Carlo, implementado no software SERPENT. Os steps de tempo foram escolhidos de forma mais concentrada no início da operação do reator (efeito do Xe-135) e mais esparsos do meio para frente, avaliando-se a queima do combustível por 360 dias, com as seguintes divisões temporais (em dias)

$$
t=\{0 ; 0,1 ; 0,5 ; 0,75 ; 1 ; 2 ; 4 ; 5 ; 10 ; 30 ; 60 ; 120 ; 180 ; 240 ; 300 ; 360\}
$$


As principais variáveis analisadas ao longo da queima foram o efeito do Xe-135 no início da operação do reator e a queima média total do U-235 nos núcleos. Demais isótopos também foram calculados, mas não possuem importância significativa para o presente estudo. As figuras a seguir (Fig. 54 a Fig. 57) ilustram a variação do fator de multiplicação com o passar do tempo devido à depleção do combustível para cada núcleo, levando em conta o ciclo completo de 360 dias.

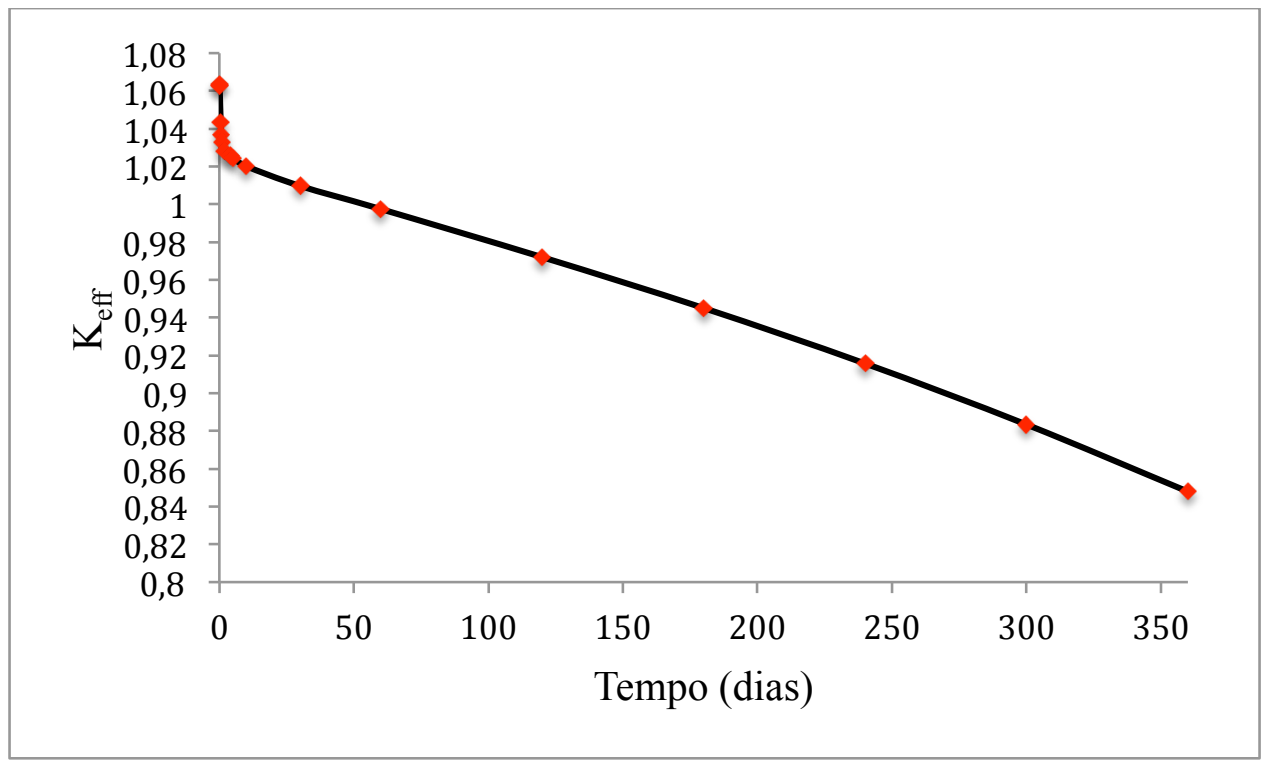

Figura 53 - Núcleo 8: Variação do fator de multiplicação com o tempo (queima).

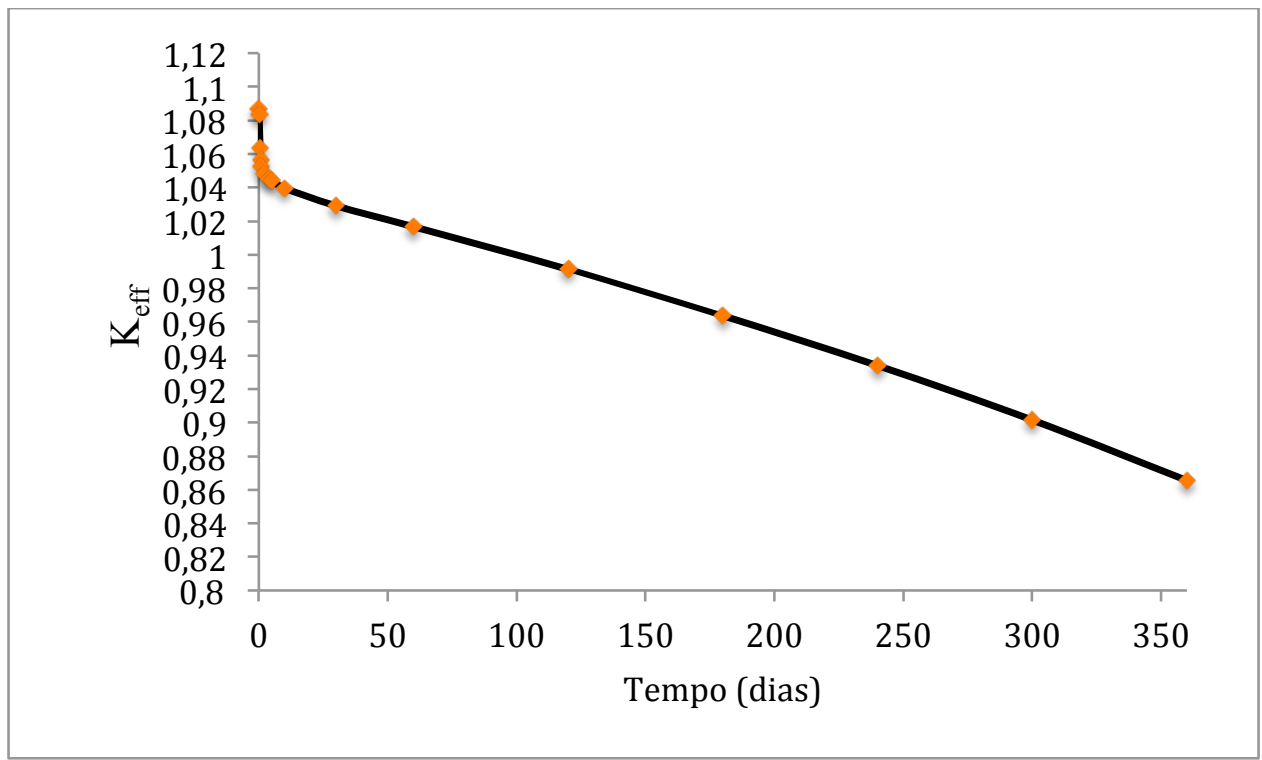

Figura 54 - Núcleo 8*: Variação do fator de multiplicação com o tempo (queima). 


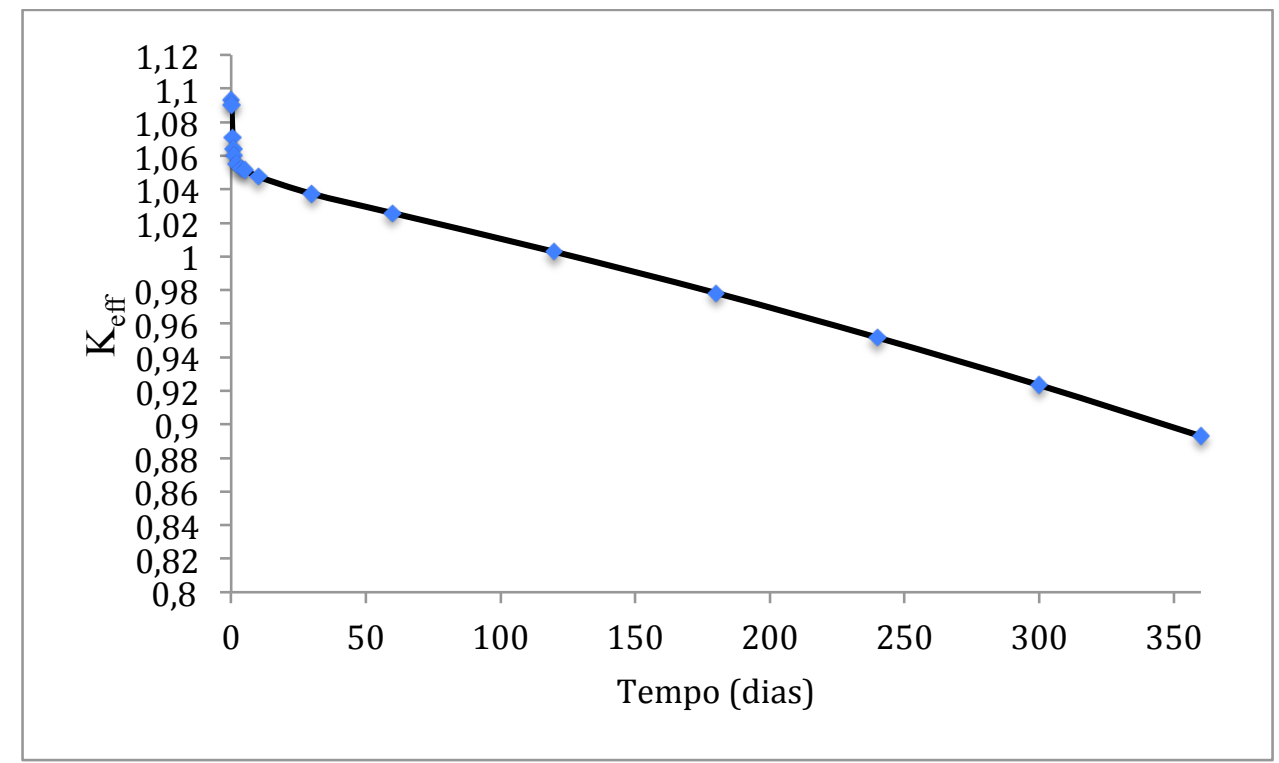

Figura 55 - Núcleo 9: Variação do fator de multiplicação com o tempo (queima).

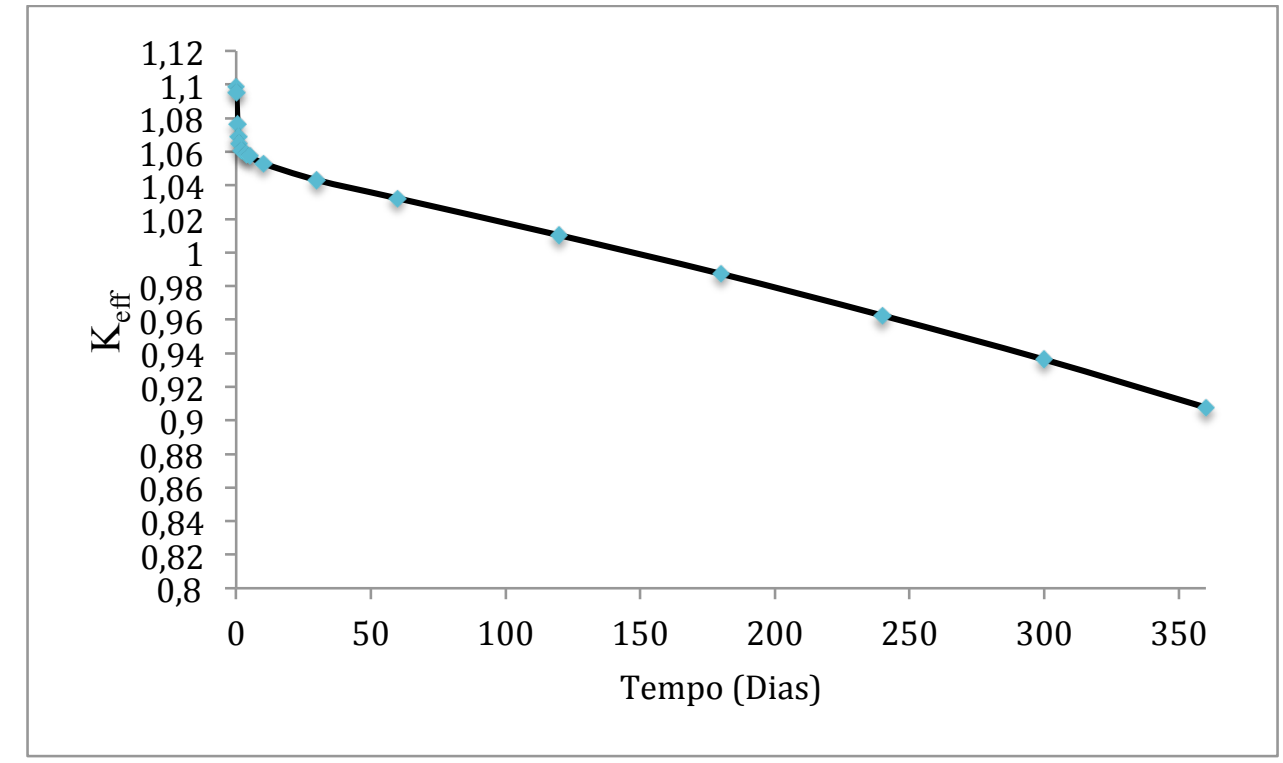

Figura 56 - Núcleo 10: Variação do fator de multiplicação com o tempo (queima).

Os núcleos 5,6 e 7 não possuem excesso de reatividade suficiente para manter o reator ligado (Fig. 58). 


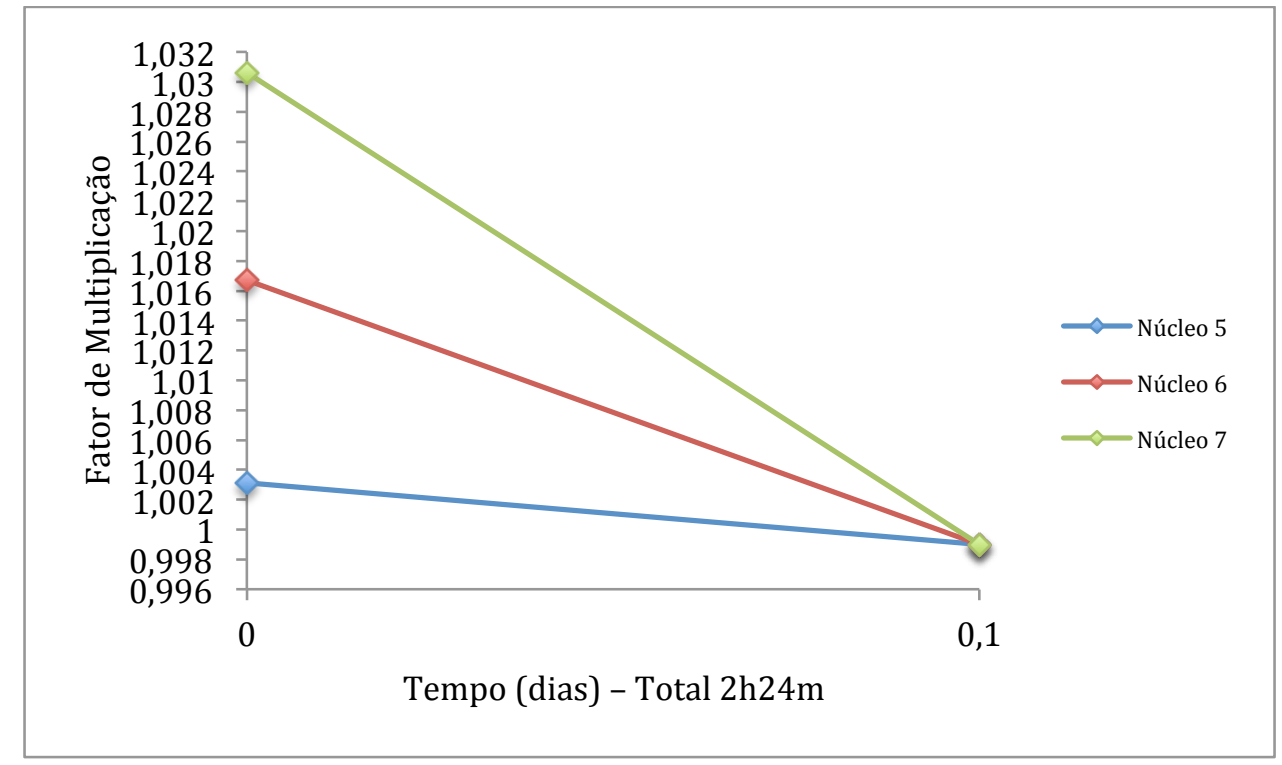

Figura 57 - Núcleos 5, 6 e 7. Pouco excesso de reatividade para a operação.

As próximas figuras (Fig. 59 a Fig. 62 ) mostram com detalhes o que ocorre no início da operação do reator (para cada configuração), considerando a variação do fator de multiplicação e a produção do Xe-135.

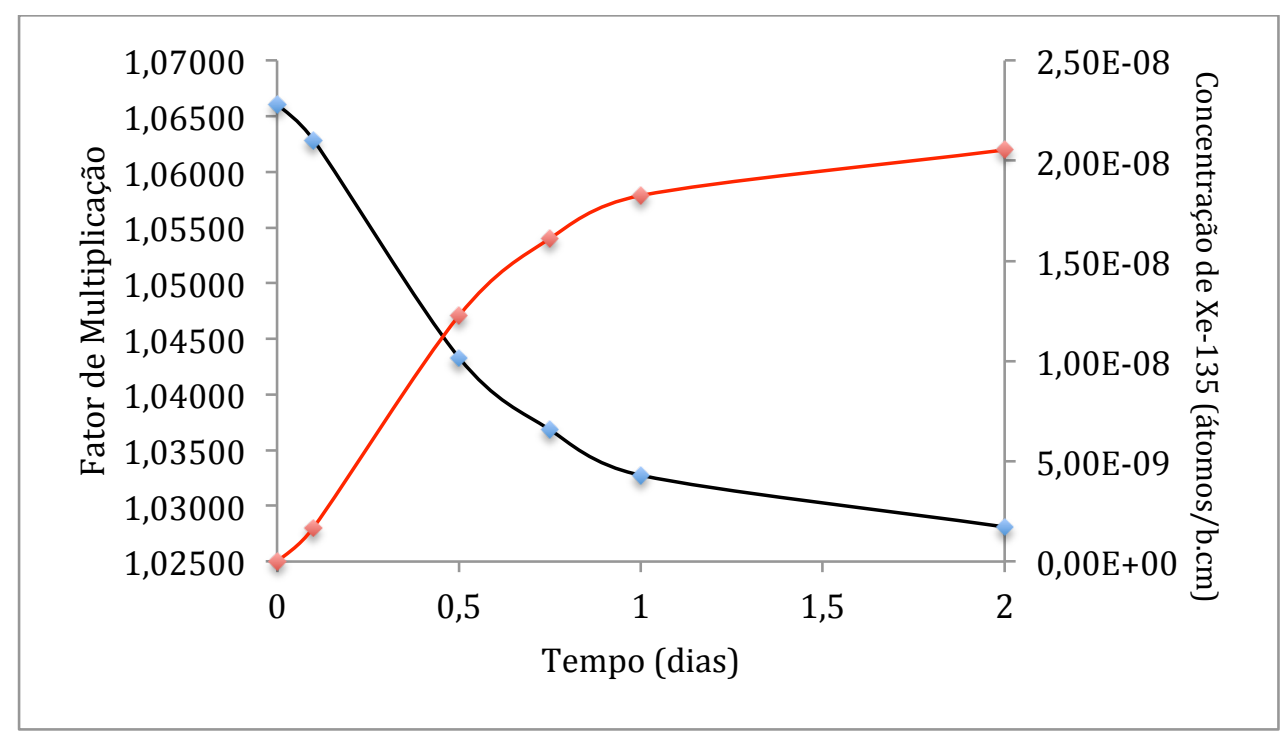

Figura 58 - Núcleo 8: Variação do fator de multiplicação e a produção de Xe-135 nos primeiros dias de operação do reator. 


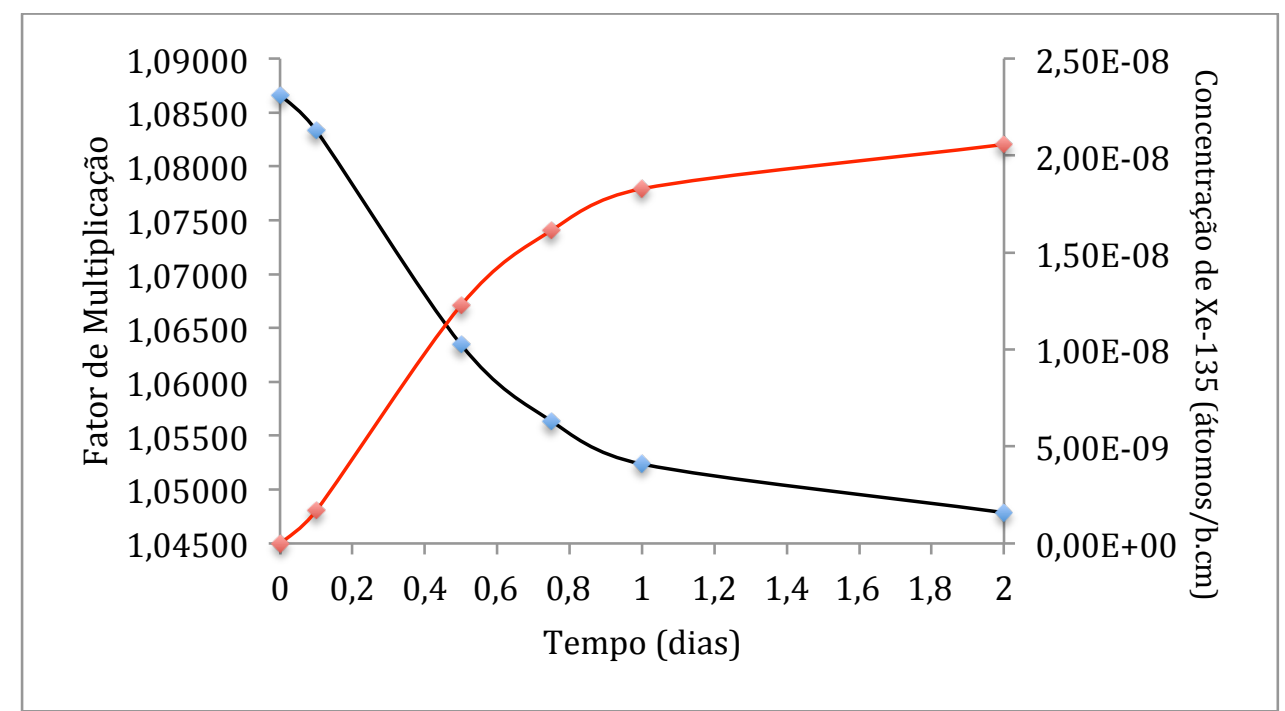

Figura 59 - Núcleo 8*: Variação do fator de multiplicação e a produção de Xe-135 nos primeiros dias de operação do reator.

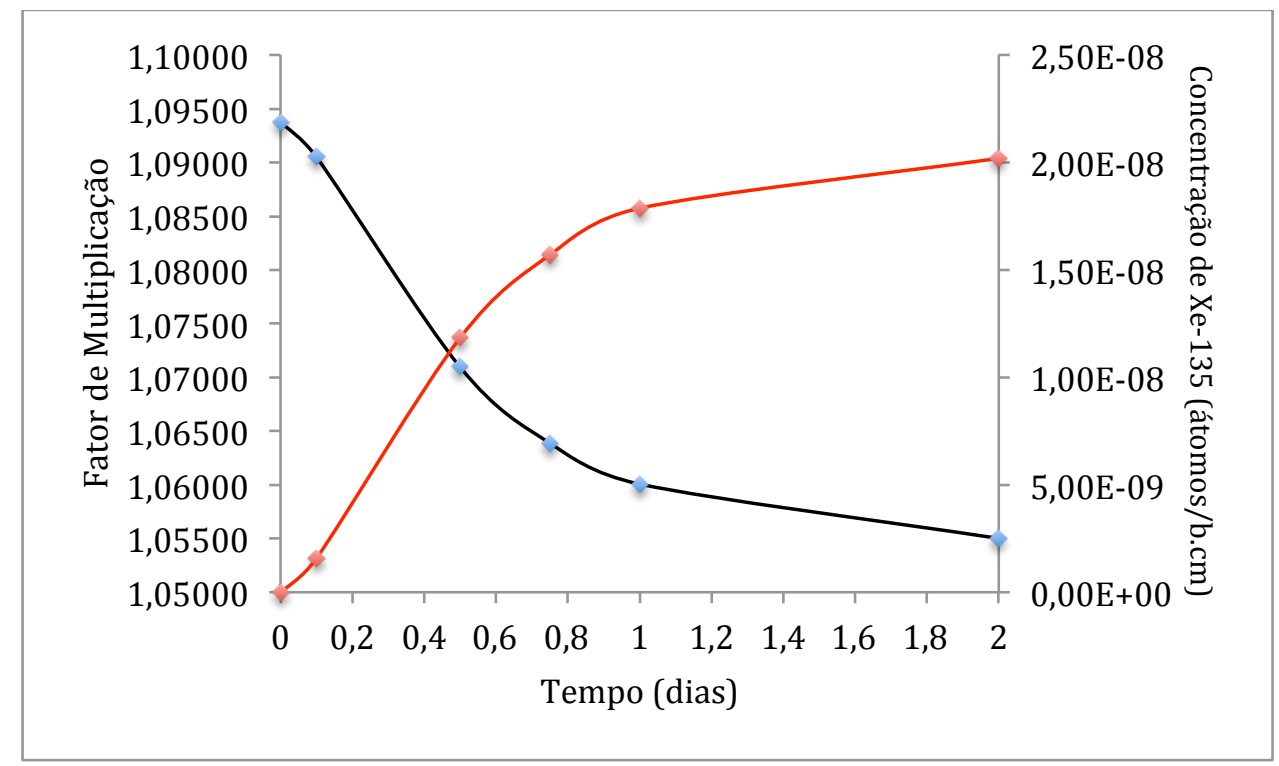

Figura 60 - Núcleo 9: Variação do fator de multiplicação e a produção de Xe-135 nos primeiros dias de operação do reator. 


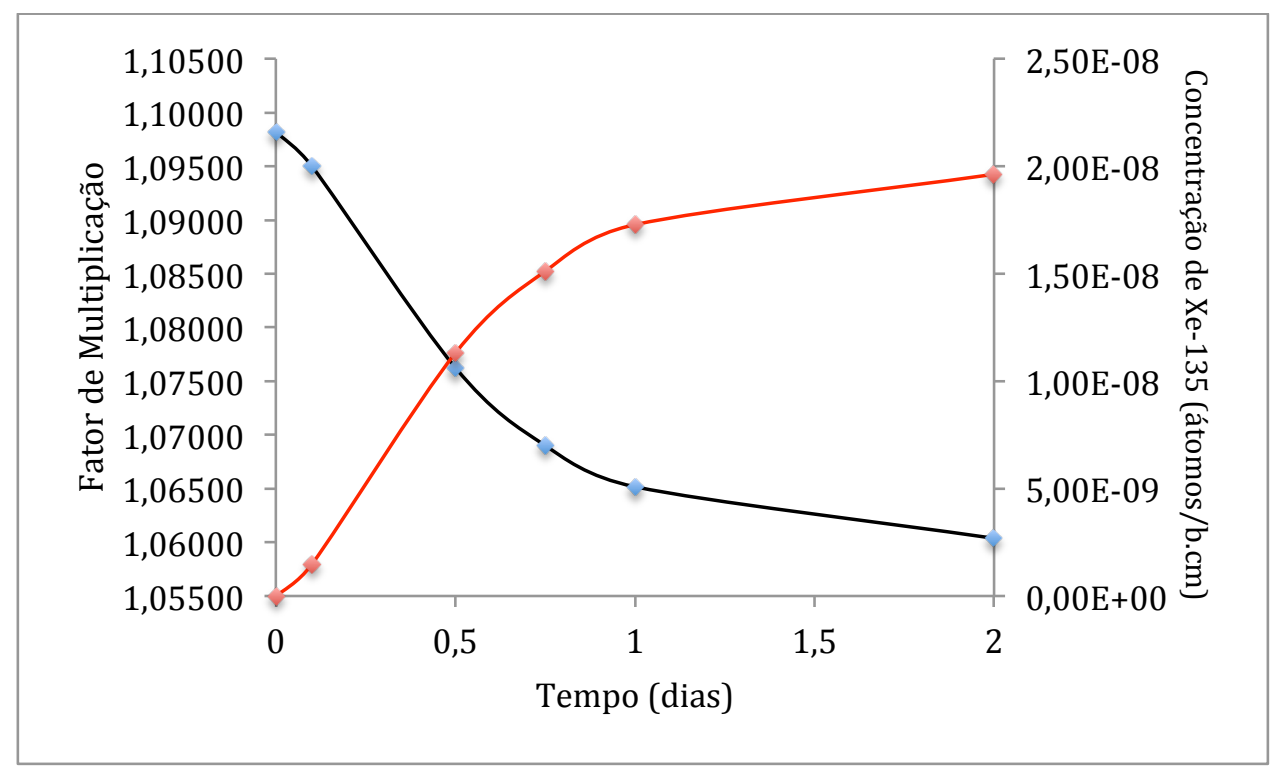

Figura 61 - Núcleo 10: Variação do fator de multiplicação e a produção de Xe-135 nos primeiros dias de operação do reator.

Uma análise mais detalhada nos arredores da criticalidade também está ilustrada na próxima figura (Fig. 63) e na Tabela 8, para as configurações 8, 8*, 9 e 10 .

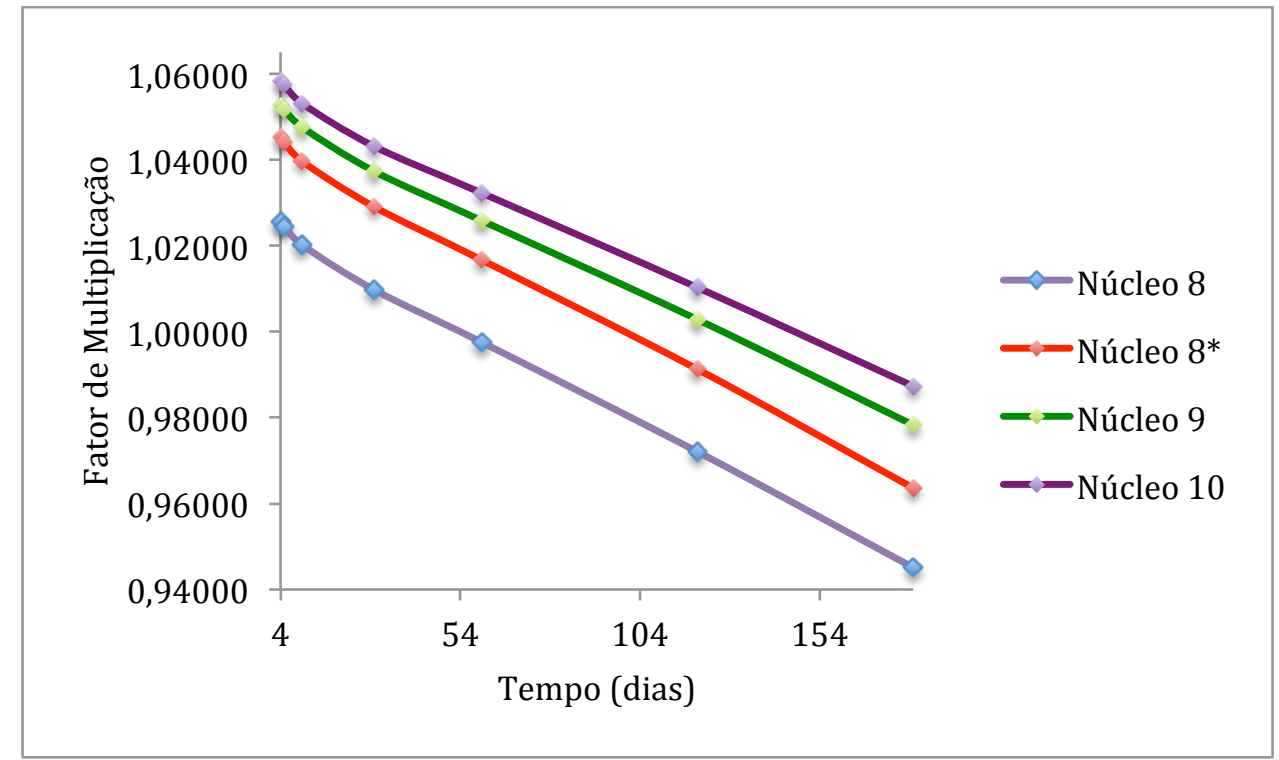

Figura 62 - Variação do Fator de multiplicação nas redondezas da criticalidade. 
Tabela 8 - Avaliação do fator de multiplicação nos arredores da criticalidade. Configurações $8,8^{*}, 9$ e 10 .

\begin{tabular}{|c|c|c|c|c|}
\cline { 2 - 5 } & Núcleo 8 & Núcleo 8* & Núcleo 9 & Núcleo 10 \\
\hline Tempo (dias) & \multicolumn{3}{|c|}{ Keff } \\
4 & 1,02575 & 1,04520 & 1,05264 & 1,05833 \\
5 & 1,02448 & 1,04406 & 1,05164 & 1,05742 \\
10 & 1,02018 & 1,03963 & 1,04758 & 1,05310 \\
30 & 1,00975 & 1,02907 & 1,03733 & 1,04313 \\
60 & 0,99751 & 1,01666 & 1,02582 & 1,03224 \\
120 & 0,97203 & 0,99123 & 1,00281 & 1,01025 \\
180 & 0,94510 & 0,96360 & 0,97825 & 0,98729 \\
\hline
\end{tabular}

As Tabelas 9, 10, 11 e 12 ilustram a queima média do combustível em cada configuração, sendo o período de tempo aquele a partir do início da operação do reator até o momento em que se atinge a criticalidade.

Tabela 9 - Queima média do combustível para o núcleo 8 ao longo do tempo.

\begin{tabular}{|c|c|c|}
\hline \multicolumn{3}{|c|}{ Núcleo 8} \\
\hline Tempo (dias) & U235 (átomo/b.cm) & Queima (\%) \\
\hline 0 & $2,11 \mathrm{E}-03$ & 0,00 \\
\hline 0,1 & $2,11 \mathrm{E}-03$ & 0,01 \\
\hline 0,5 & $2,11 \mathrm{E}-03$ & 0,07 \\
\hline 0,75 & $2,11 \mathrm{E}-03$ & 0,10 \\
\hline 1 & $2,11 \mathrm{E}-03$ & 0,13 \\
\hline 2 & $2,10 \mathrm{E}-03$ & 0,26 \\
\hline 4 & $2,10 \mathrm{E}-03$ & 0,53 \\
\hline 5 & $2,10 \mathrm{E}-03$ & 0,66 \\
\hline 10 & $2,08 \mathrm{E}-03$ & 1,32 \\
\hline 30 & 2,03E-03 & 3,95 \\
\hline 60 & 1,94E-03 & 7,87 \\
\hline 120 & 1,78E-03 & 15,60 \\
\hline 180 & $1,62 \mathrm{E}-03$ & 23,19 \\
\hline 240 & $1,46 \mathrm{E}-03$ & 30,65 \\
\hline 300 & $1,31 \mathrm{E}-03$ & 37,98 \\
\hline 360 & $1,16 \mathrm{E}-03$ & 45,15 \\
\hline
\end{tabular}

Tabela 10 - Queima média do combustível para o núcleo 8* ao longo do tempo.

\begin{tabular}{ccc}
\multicolumn{3}{c}{ Núcleo $8^{*}$} \\
Tempo (dias) & U235 (átomo/b.cm) & Queima (\%) \\
\hline 0 & $2,11 \mathrm{E}-03$ & 0,00 \\
0,1 & $2,11 \mathrm{E}-03$ & 0,01 \\
0,5 & $2,11 \mathrm{E}-03$ & 0,07 \\
0,75 & $2,11 \mathrm{E}-03$ & 0,10 \\
1 & $2,11 \mathrm{E}-03$ & 0,13 \\
2 & $2,10 \mathrm{E}-03$ & 0,26 \\
4 & $2,10 \mathrm{E}-03$ & 0,53 \\
5 & $2,10 \mathrm{E}-03$ & 0,66 \\
10 & $2,08 \mathrm{E}-03$ & 1,32 \\
30 & $2,03 \mathrm{E}-03$ & 3,95 \\
60 & $1,94 \mathrm{E}-03$ & 7,87 \\
120 & $1,78 \mathrm{E}-03$ & 15,60 \\
180 & $1,62 \mathrm{E}-03$ & 23,19 \\
240 & $1,46 \mathrm{E}-03$ & 30,65 \\
300 & $1,31 \mathrm{E}-03$ & 37,98 \\
360 & $1,16 \mathrm{E}-03$ & 45,15
\end{tabular}


Tabela 11 - Queima média do combustível para o núcleo 9 ao longo do tempo.

\begin{tabular}{ccc} 
& Núcleo 9 & \\
Tempo (dias) & U235 (átomo/b.cm) & Queima (\%) \\
\hline 0 & $2,11 \mathrm{E}-03$ & 0,00 \\
0,1 & $2,11 \mathrm{E}-03$ & 0,01 \\
0,5 & $2,11 \mathrm{E}-03$ & 0,06 \\
0,75 & $2,11 \mathrm{E}-03$ & 0,09 \\
1 & $2,11 \mathrm{E}-03$ & 0,12 \\
2 & $2,10 \mathrm{E}-03$ & 0,24 \\
4 & $2,10 \mathrm{E}-03$ & 0,48 \\
5 & $2,10 \mathrm{E}-03$ & 0,60 \\
10 & $2,08 \mathrm{E}-03$ & 1,21 \\
30 & $2,03 \mathrm{E}-03$ & 3,62 \\
60 & $1,96 \mathrm{E}-03$ & 7,20 \\
120 & $1,81 \mathrm{E}-03$ & 14,29 \\
180 & $1,66 \mathrm{E}-03$ & 21,25 \\
240 & $1,52 \mathrm{E}-03$ & 28,11 \\
300 & $1,37 \mathrm{E}-03$ & 34,84 \\
360 & $1,23 \mathrm{E}-03$ & 41,46
\end{tabular}

Tabela 12 - Queima média do combustível para o núcleo 10 ao longo do tempo.

$\begin{array}{ccc}\text { Tempo (dias) } & \text { Núcleo } 10 & \\ 0 & \text { U235 (atomo/b.cm) } & \text { Queima }(\%) \\ 0,1 & 2,11 \mathrm{E}-03 & 0,00 \\ 0,5 & 2,11 \mathrm{E}-03 & 0,01 \\ 0,75 & 2,11 \mathrm{E}-03 & 0,06 \\ 1 & 2,11 \mathrm{E}-03 & 0,08 \\ 2 & 2,11 \mathrm{E}-03 & 0,11 \\ 4 & 2,10 \mathrm{E}-03 & 0,22 \\ 5 & 2,10 \mathrm{E}-03 & 0,45 \\ 10 & 2,10 \mathrm{E}-03 & 0,56 \\ 30 & 2,09 \mathrm{E}-03 & 1,11 \\ 60 & 2,04 \mathrm{E}-03 & 3,33 \\ 120 & 1,97 \mathrm{E}-03 & 6,64 \\ 180 & 1,83 \mathrm{E}-03 & 13,17 \\ 240 & 1,70 \mathrm{E}-03 & 19,61 \\ 300 & 1,56 \mathrm{E}-03 & 25,95 \\ 360 & 1,43 \mathrm{E}-03 & 32,20 \\ & 1,30 \mathrm{E}-03 & 38,34\end{array}$




\section{Novos Núcleos para o Reator IEA-R1: Simulação de um APR}

Para completar o estudo de possíveis novos núcleos para o reator nuclear IEA-R1, a simulação de um APR (Acidente de Perda de Refrigerante) ou LOCA (Loss of Coolant Accident) é realizada nesse capítulo.

Esse tipo de análise se enquadra no tema referente à análise de segurança, que por sua vez verifica a resposta do reator frente a eventos iniciadores postulados, tais como falhas ou mau funcionamento de sistemas e componentes, eventos externos ou internos e também erros de operação (humanos). Todos os eventos citados podem conduzir a condições de acidentes e devem ser levados em conta no projeto de uma instalação nuclear.

Através da análise de segurança, define-se os limites e condições de operação para um determinado reator nuclear, as especificações técnicas de projeto dos componentes e também sistemas para garantir a saúde e segurança do público em geral. Os resultados finais de uma análise desse tipo devem ser inseridos no Relatório de Análise de Segurança (RAS) do reator em estudo.

Uma vez que o presente estudo não acarreta modificações nas instalações do reator nuclear IEA-R1, sendo essas tão somente no núcleo, esforços devem ser concentrados em casos postulados limitantes que dependam diretamente das mudanças realizadas.

Dos vários possíveis casos postulados que podem acarretar acidentes em uma instalação nuclear, os APR (LOCA) têm sido considerados como sendo os mais limitantes (severos) [34,35] e por isso são a tônica da presente seção.

Dessa forma, a análise de segurança foi desenvolvida com ênfase nos acidentes de perda de refrigerante (APR), qualitativa e quantitativamente. 


\section{1 - Metodologia para a Simulação de APR}

Os APR englobam tanto a perda total, quanto a perda parcial de refrigerante do núcleo do reator. Abaixo, encontram-se, de forma crescente, os graus desses eventos:

- Esvaziamento parcial da piscina sem o descobrimento do núcleo;

- Esvaziamento parcial da piscina com o descobrimento parcial do núcleo;

- Esvaziamento total da piscina com o descobrimento total do núcleo.

Assim, os possíveis eventos iniciadores de perda de refrigerante estão listados abaixo, segundo recomendações da Safety Series (35-G1 e 35-S1) [17, 35]:

- Ruptura da fronteira do circuito primário;

- Danos na piscina;

- Esvaziamento da piscina;

- Falhas nos tubos de irradiação ou outras penetrações.

Algumas das consequências previsíveis e decorrentes dos eventos citados acima são:

- Diminuição ou perda da barreira biológica exercida pela água da piscina;

- Fusão do combustível devido à degradação do resfriamento das placas com consequente liberação de produtos de fissão e a liberação de efluentes líquidos radioativos no ambiente.

Além disso, os reatores nucleares possuem uma característica diferente de outras máquinas, possuindo, mesmo após o desligamento, um calor residual devido ao decaimento dos produtos de fissão. A taxa de liberação dessa energia depende do tempo e da potência de operação do reator antes do desligamento e também das características do combustível utilizado. Essa energia residual é a principal responsável pelo aumento de temperatura nas placas combustíveis do reator durante um APR. Assim, faz-se necessário pontuar dois parâmetros importantes a serem determinados na análise dos APR: 
1. O tempo para o descobrimento completo do núcleo;

2. A temperatura máxima atingida nas placas combustíveis;

Os limites para as temperaturas de empolamento para combustíveis à base de Urânio dispersos e revestidos em alumínio são da ordem de $475^{\circ} \mathrm{C}$ a $550^{\circ} \mathrm{C}$ [2]. Outro fato importante é que, com uma espessura pequena, alta condutividade térmica e baixos valores para o coeficiente de transferência de calor por convecção natural entre a placa e o ar do canal de resfriamento, não se encontram grandes diferenças entre as temperaturas no centro do combustível e na superfície do revestimento. Logo, pode-se avaliar as consequências de APR, bem como determinar as medidas preventivas para sua minimização.

\section{2 - Cálculo do Tempo de Esvaziamento da Piscina}

Para determinar o tempo de esvaziamento da piscina na qual se encontra o reator, devese resolver as equações da energia e massa para um volume de controle compreendido entre a piscina e a ruptura na tubulação, conforme ilustra a Fig. 64.

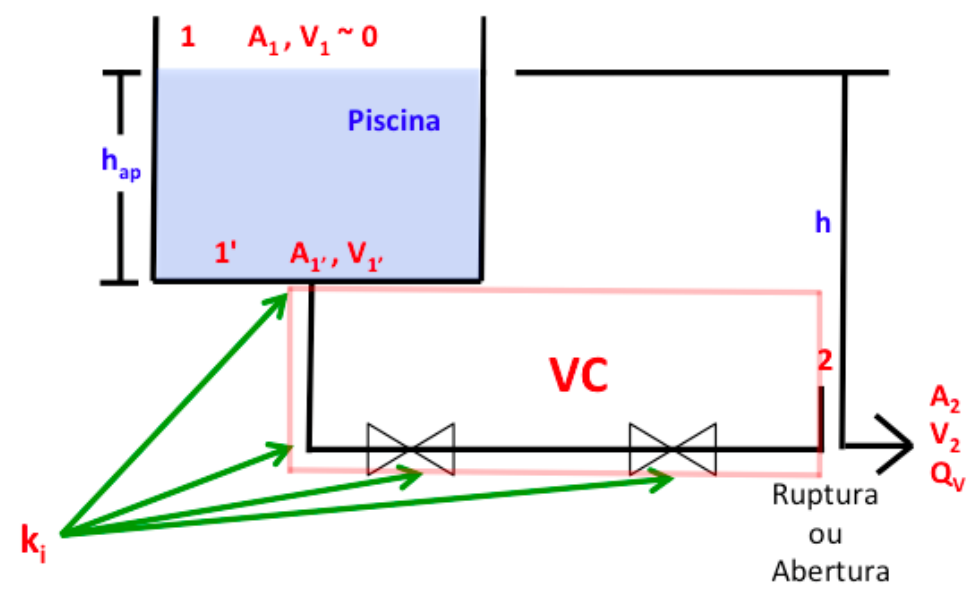

Figura 63 - Representação esquemática da piscina e ruptura na tubulação do IEA-R1.

Aplicando-se o balanço de energia conforme mencionado anteriormente, tem-se

$$
\frac{d E}{d t}_{s i s t}=\frac{d}{d t} \int e \rho d V+\int e \rho \vec{v} \cdot \hat{n} d A
$$


com $e=d E / d m$, energia intensiva, $\rho=d m / d V$ a densidade, onde aplicando a primeira lei da termodinâmica,

$$
\dot{Q}-\dot{W}=\frac{d}{d t} \int e \rho d V+\int e \rho \vec{v} \cdot \hat{n} d A
$$

com,

$$
\begin{gathered}
e=e_{\text {interna }}+e_{\text {cinética }}+e_{\text {potencial }}+e_{\text {outras }} \\
\mathrm{e} \\
\dot{W}=\dot{W}_{\text {eixos }}+\dot{W}_{\text {pressão }}+\dot{W}_{\text {viscoso }}
\end{gathered}
$$

Os termos relacionados ao calor podem derivar de fenômenos de condução, convecção e radiação. Entretanto, é interessante manter esse termo da forma mais geral possível. Note que o trabalho realizado pela força gravitacional já está contabilizado no termo de energia, por isso não aparece explicitamente. Assim, considerando $e_{\text {outras }}=0$,

$$
e=e_{\text {interna }}+e_{\text {cinética }}+e_{\text {potencial }}=u+\frac{1}{2} v^{2}+g z
$$

Escrevendo de forma explícita as três formas de trabalho,

$$
\begin{gathered}
\dot{W}=\dot{W}_{\text {eixos }}+\dot{W}_{\text {pressão }}+\dot{W}_{\text {viscoso }} \\
\dot{W}=\dot{W}_{\text {eixos }}+\int p \vec{v} \cdot \hat{n} d A+\int \overleftrightarrow{\tau} \cdot \vec{v} d A
\end{gathered}
$$


Vale ressaltar que o trabalho viscoso, quando calculado sobre uma superfície sólida, pela condição de contorno na superfície (velocidade igual a zero), é identicamente nulo. Se a superfície for a de uma máquina, o trabalho na mesma já encontra-se contabilizado no termo referente ao trabalho de eixos. Em casos ideais de entradas e saídas, pode-se desprezar o termo de trabalho viscoso, uma vez que no tensor restará somente o termo normal à superfície, sendo pequeno quando comparado com os demais, a não ser em casos raros [36].

Se a superfície de controle for uma linha de corrente (streamline), como a curva superior no caso da análise da camada limite, o trabalho viscoso é relevante somente se as tensões de cisalhamento forem significativas ao longo dessa linha.

Considerando a discussão acima, pode-se reescrever o termo referente ao trabalho como

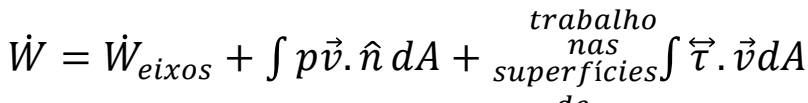

$$
\begin{aligned}
& \text { corrente }
\end{aligned}
$$

Substituindo os termos na Eq. 26, tem-se

$$
\begin{aligned}
& \dot{Q}-\dot{W}_{\text {eixos }}-\int p \vec{v} \cdot \hat{n} d A-\dot{W} \begin{array}{l}
\text { viscoso } \\
\text { Sup. de } \\
\text { Correntes }
\end{array} \\
& =\frac{d}{d t} \int\left(u+\frac{1}{2} v^{2}+g z\right) \rho d V+\int\left(u+\frac{1}{2} v^{2}+g z\right) \rho \vec{v} \cdot \hat{n} d A
\end{aligned}
$$

Repare que pode-se agrupar o termo referente ao trabalho de pressão com os termo de fluxos do lado direito da Eq. 33, pois ambos são integrais de superfície. Fazendo isso,

$$
\begin{aligned}
\dot{Q}-\dot{W}_{\text {eixos }}-\dot{W} & \begin{array}{l}
\text { viscoso } \\
\text { Sup.de } \\
\text { Correntes }
\end{array} \\
= & \frac{d}{d t} \int\left(u+\frac{1}{2} v^{2}+g z\right) \rho d V+\int\left(u+\frac{p}{\rho}+\frac{1}{2} v^{2}+g z\right) \rho \vec{v} . \hat{n} d A
\end{aligned}
$$


Reconhecendo o termo $u+\frac{p}{\rho}$ como a entalpia específica, pode-se ainda reescrever a Eq. 34 como,

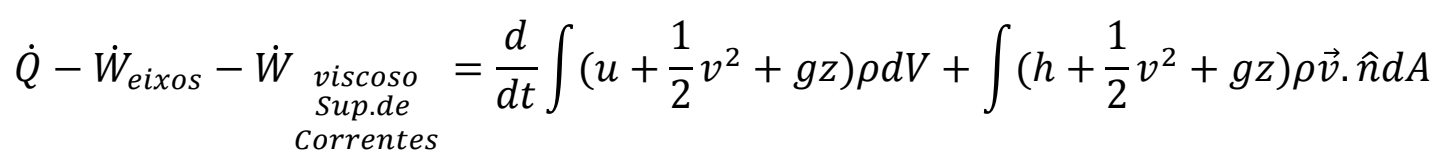

Lembrando que o trabalho devido às forças de cisalhamento são raramente importantes no presente estudo. Uma vez realizado o balanço de energia para a piscina e ruptura, falta somente transformar o caso geral tridimensional (3D) no caso particular onde considera-se o problema unidimensional (1D). Fazendo isso e considerando nulos os termos de trabalho pela natureza do problema, tem-se

$$
\begin{aligned}
\dot{Q}=\frac{d}{d t} \int(u+ & \left.\frac{1}{2} v^{2}+g z\right) \rho d V+\sum\left(h+\frac{1}{2} v^{2}+g z\right) \dot{m}_{\text {saidas }} \\
& -\sum\left(h+\frac{1}{2} v^{2}+g z\right) \dot{m}_{\text {entradas }}
\end{aligned}
$$

onde os valores das grandezas nos somatórios são valores médios nos locais onde são calculados.

Repare que, para o caso de interesse, onde o volume de controle se situa entre a piscina e a ruptura na tubulação (Fig. 65) e, para um regime estacionário, a equação anterior se reduz a

$$
\frac{\dot{Q}}{\dot{m}}=\left(u_{2}+\frac{p_{2}}{\rho}+\frac{1}{2} v^{2}{ }_{2}+g z_{2}\right)-\left(u_{1}{ }^{\prime}+\frac{p_{1 \prime}}{\rho}+\frac{1}{2} v^{2}{ }_{1}+g z_{1}{ }^{\prime}\right)
$$


Reescrevendo usando a regra da cadeia no lado esquerdo e escrevendo as grandezas na saída da piscina e entrada da tubulação em função das grandezas no topo da mesma e reagrupando, tem-se

$$
\begin{aligned}
& \underbrace{\left(u_{2}-u_{1}\right)-\frac{d Q}{d m}}_{\text {Perda de carga total }=h_{T}}+\left(\frac{p_{2}}{\rho}+\frac{1}{2} v_{2}^{2}-g h\right) \\
& =\left(\frac{p_{1}}{\rho}+\rho g h_{a p}+\frac{p_{1}}{\rho}-\frac{p_{1^{\prime}}}{\rho}+g h_{a p}-g h_{a p}\right)
\end{aligned}
$$

$$
\underbrace{\left(u_{2}-u_{1}\right)-\frac{d Q}{d m}}_{\text {Perda de carga total }=h_{T}}+\left(\frac{p_{2}}{\rho}+\frac{1}{2} v^{2}{ }_{2}-g h\right)=\left(\frac{p_{1}}{\rho}+\rho g h_{a p}+\frac{p_{1}}{\rho}-\frac{p_{1}}{\rho}-g h_{a p}\right)
$$

$$
\underbrace{\left(u_{2}-u_{1}\right)-\frac{d Q}{d m}}_{\text {Perda de carga total }=h_{T}}+(\underbrace{\frac{p_{2}}{\rho}}_{p 1=p 2}+\frac{1}{2} v^{2}{ }_{2}-g h)=\left(\frac{p_{1}}{\rho}\right)
$$

onde o termo acima sublinhado representa a conversão irreversível de energia mecânica da seção 1 em energia térmica indesejável na seção 2 e também a perda de energia através de processos de transferência de calor. Note que, pela análise anterior, não há diferença significativa entre as energias internas nos pontos 1 e 1' (sem variação sensível ou latente).

De forma conservativa, consideram-se as perdas de carga somente como sendo as perdas de pressão nas singularidades. Simplificando para as condições do presente estudo,

$$
\underbrace{\left(u_{2}-u_{1}\right)-\frac{d Q}{d m}}_{\text {Perda de carga total }=h_{T}}+(\underbrace{\frac{p_{2}}{\rho}}_{p 1=p 2}+\frac{1}{2} v_{2}^{2}-g h)=\left(\frac{p_{1}}{\rho}\right)
$$




$$
h_{T}+\left(\frac{1}{2} v_{2}^{2}-g h\right)=0
$$

Portanto,

$$
h_{T}=g h-\frac{1}{2} v^{2}
$$

Expressando em unidades de comprimento, ou seja, dividindo os termos pela aceleração gravitacional e usando $Q_{V}=A_{2} v_{2}$,

$$
h_{T}^{\prime}=h-\frac{Q_{V}{ }^{2}}{2 g A_{2}^{2}} \quad \operatorname{com} \quad h_{T}^{\prime}=\frac{h_{T}}{g}
$$

Assim, escrevendo as perdas de cargas singulares, tem-se

$$
h_{T}^{\prime}=\sum_{\text {sing. }} K_{i} \frac{Q_{V}{ }^{2}}{2 g{A_{i}}^{2}}=h-\frac{Q_{V}{ }^{2}}{2 g A_{2}^{2}}
$$

resolvendo para a vazão,

$$
\left(\sum_{\text {sing. }} \frac{K_{i}}{{A_{i}}^{2}}+\frac{1}{{A_{2}}^{2}}\right) \frac{Q_{V}^{2}}{2 g}=h
$$




$$
Q_{V}=\sqrt{\frac{2 g h}{\left(\left(\sum_{\text {sing }} \cdot \frac{K_{i}}{A_{i}^{2}}\right)+\frac{1}{{A_{2}}^{2}}\right)}}
$$

Sendo $Q_{V}$ a vazão volumétrica, $A_{i}$ as áreas transversais nas seções i e $K_{i}$, os coeficientes de perda de carga nas singularidades “i”, obtidos a partir das referências $[37,38,39]$.

Realizando um balanço de massa para o mesmo volume de controle, pode-se agora determinar uma expressão para o cálculo do tempo de descobrimento do núcleo. Partindo da equação de balanço para um volume de controle,

$$
\underbrace{\frac{d m}{d t} \text { sist }_{i}}_{\begin{array}{c}
=0 \\
\text { por } \\
\text { definição }
\end{array}}=\frac{d}{d t} \int \rho d V+\int \rho \vec{v} \cdot \hat{n} d A
$$

Considerando o fluido incompressível (água leve desmineralizada!) e o caso unidimensional,

$$
\begin{gathered}
0=\rho \frac{d}{d t} V+\rho v_{2} A_{2} \\
0=\frac{d}{d t}\left(A_{1}(h-\text { const })\right)+v_{2} A_{2}
\end{gathered}
$$

Note que a altura que entra no cálculo do volume é a altura da piscina referente a sua base, que é calculada pela diferença da altura total $h$ e a altura entre a base da ruptura e a base da piscina, que é constante. Assim,

$$
0=A_{1} \frac{d h}{d t}+v_{2} A_{2}
$$




$$
\frac{d h}{d t}=-v_{2} \frac{A_{2}}{A_{1}}=-\frac{Q_{V}}{A_{1}}
$$

Repare que, a rigor, tanto $h$, quanto a vazão na saída da ruptura variam com o tempo, pois essa vazão também depende de $h$ em última instância (Eq. 47). Esse problema pode ser resolvido de três maneiras distintas: Considerar o processo quase-estático para o cálculo da vazão (cálculo é conservativo), assumindo que a vazão de saída é aquela do instante em que ela é máxima, ou seja, quando a coluna de água é maior; resolver a Eq. 52, de variáveis separáveis, encontrando o valor de h em função do tempo (Eq. 53); resolver numericamente o problema.

$$
h(t)=\left[\sqrt{h_{0}}-\frac{\alpha}{2 A_{1}} t\right]^{2}
$$

onde $\alpha=\sqrt{\frac{2 g}{\left(\sum \frac{K_{i}}{\left.A_{i}{ }^{2}+\frac{1}{A_{2}{ }^{2}}\right)}\right.}}$.

Para resolver a Eq. 52, uma vez que tanto a altura, quanto a vazão dependem do tempo, aproxima-se a derivada temporal da seguinte forma,

$$
\frac{d h}{d t} \sim \frac{h(t)-h(t-\Delta t)}{\Delta t}=-\frac{Q_{V}}{A_{1}}
$$

de forma que

$$
h(t)=h(t-\Delta t)-\frac{Q_{V}}{A_{1}} \Delta t
$$


e numericamente pode ser representado como

$$
h_{i}=h_{i-1}-\frac{Q_{V_{i-1}}}{A_{1}} \Delta t
$$

sendo a equação necessária para determinar a altura da piscina em função do tempo, quando na presença de um evento que resulte em APR. Assim, partindo-se da altura inicial da coluna d'água e da vazão identicamente nula (sem ruptura), pode-se determinar a altura com o passar do tempo, através da propagação dos valores via Eq. 56 e 47.

Para cada valor de altura encontrada, pode-se, iterativamente, determinar o instante de tempo em que o valor da coluna d'água na piscina do reator atinge o valor zero (caso de interesse). Contabilizando o tempo decorrido para tal, determina-se o intervalo de tempo necessário para o completo esvaziamento da piscina e consequente exposição total do núcleo.

O caso mais crítico porém, deve levar em conta uma ruptura na tubulação próxima à entrada da piscina e, nesse caso, deve-se admitir vazamento tanto pelo lado do difusor, como através do núcleo, situação ilustrada na Fig. 65.

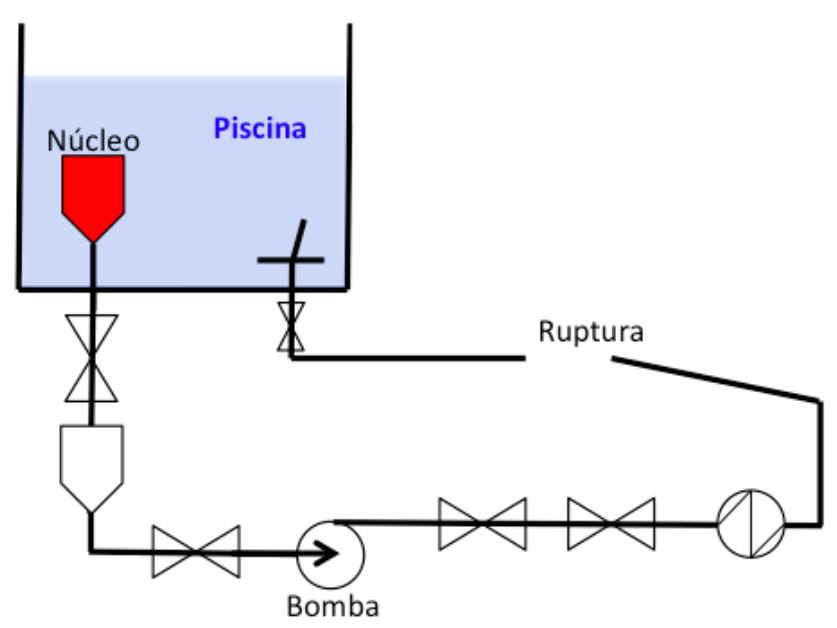

Figura 64 - Ruptura na tubulação do circuito primário do reator IEA-R1. 
Assim, a Eq. 47 deve ser modificada, acrescentando a vazão volumétrica pelo lado do núcleo $Q_{B}($ bomba),

$$
Q_{V}=\underbrace{\sqrt{\left(\left(\sum_{\text {sing }} \frac{K_{i}}{A_{i}{ }^{2}}\right)+\frac{1}{A_{2}{ }^{2}}\right)}}+Q_{B}=Q_{D}+Q_{B}
$$

onde $Q_{D}$, expressão sublinhada, é a vazão volumétrica pelo difusor.

\section{3 - O Programa LOSS e os Eventos Postulados para o Reator IEA-R1}

O programa computacional LOSS [40] foi desenvolvido no IPEN/CNEN-SP para a análise de acidentes APR postulados no reator IEA-R1. Esse programa determina o tempo de esvaziamento da piscina do reator levando em conta não somente o caso em particular analisado na seção anterior, mas também outros eventos postulados que são:

- Ruptura dos tubos do sistema pneumático de irradiação (SPI);

- Falha nos drenos da piscina - Ruptura dos tubos de acesso ao sistema de retratamento de água (SRA);

- Ruptura da fronteira do circuito primário (caso analisado anteriormente);

- Abertura indevida dos drenos do SRA;

- Falha nos tubos colimadores (BH-3).

Logo, para cada evento acima postulado, o programa LOSS determina a altura da coluna d'água na piscina em função do tempo. Na próxima seção, cada evento é analisado e o tempo para o descobrimento total do núcleo é determinado. 


\subsection{1 - Ruptura dos Tubos do Sistema Pneumático de Irradiação (SPI)}

O SPI é composto por oito tubos de aço inoxidável que penetram o interior da piscina pela parte inferior do piso e se estendem até meia altura da parte lateral do núcleo do reator, de forma que quatro tubos ficam dispostos de um lado do núcleo e os outros, no lado oposto. Na parte externa à piscina, o SPI conta com tubos plásticos não estanques.

O sistema é usado para irradiação de amostras ("coelhos") e o evento postulado de perda de refrigerante seria devido ao rompimento dos tubos de aço no interior da piscina, que se daria por uma ruptura em guilhotina em decorrência de um forte impacto externo. Falhas nos tubos ou nas soldas podem ser identificadas através da manutenção corriqueira do reator, ou por umedecimento das amostras irradiadas, diminuindo assim a probabilidade de ocorrência desse acidente [40]. A Tabela 13 ilustra os dados de entrada do programa LOSS e a Tabela 14, os dados referentes ao caso de ruptura dos tubos do SPI. A Fig. 66 ilustra a variação da altura de água na piscina com o tempo.

Tabela 13 - Dados de entrada do programa LOSS.

\begin{tabular}{|c|c|c|}
\hline $\begin{array}{l}\text { Dados de } \\
\text { Entrada }\end{array}$ & Descrição & \\
\hline $\mathrm{NAC}=1$ & Ruptura dos tubos do SPI & \\
\hline $\mathrm{NAC}=2$ & Falha nos drenos da piscina & \\
\hline $\mathrm{NAC}=3$ & Ruptura da fronteira do primário & \\
\hline $\mathrm{NAC}=4$ & Abertura dos drenos do SRA & \\
\hline $\mathrm{NAC}=5$ & Falha nos tubos colimadores & \\
\hline DT & Incremento de tempo & \\
\hline TMAX & Tempo máximo do transiente & \\
\hline APIS & Área transversal da piscina $\left(28,737 \mathrm{~m}^{2}\right)$ & Informações \\
\hline $\mathrm{H}$ & Coluna Inicial de água total (m) & $\begin{array}{l}\text { Diferença entre o nível de água na superfície } \\
\text { da piscina e o nível no local da abertura }\end{array}$ \\
\hline HAP & Coluna inicial de água na piscina (m) & $\begin{array}{l}\text { Corresponde à coluna de água do fundo a } \\
\text { superfície da piscina }(8,8 \mathrm{~m})\end{array}$ \\
\hline FCV & Fator de correção do volume útil da piscina & $\begin{array}{c}\text { Relação entre o volume total e o volume útil } \\
\text { de água na piscina }(1,1)\end{array}$ \\
\hline DRUP & Diâmetro da ruptura $(\mathrm{m})$ & $\begin{array}{c}\text { Somente usado se NAC }=1 \\
(\mathrm{DRUP}=0,0450 \mathrm{~m}), 2(\mathrm{DRUP}=0,0524 \mathrm{~m}), 3 \\
(\mathrm{DRUP}=0,267 \mathrm{~m}) \text { ou } 5(\mathrm{DRUP}=0,2 \mathrm{~m})\end{array}$ \\
\hline NT & Número de tubos dos "coelhos" ou colimadores rompidos & $\begin{array}{c}\text { Somente usado se NAC }=1 \text { ou } 5-\text { de } 2 \text { a } 8 \\
\text { tubos (coelhos) e de } 1 \text { a } 12 \text { tubos } \\
\text { colimadores. }\end{array}$ \\
\hline $\mathrm{KCV}$ & Coeficiente de perda de carga nas curvas & $\begin{array}{c}\text { Somente usado se } \mathrm{NAC}=2(\mathrm{KCV}=2,85) \text { ou } 3 \\
(\mathrm{KCV}=0,42) .\end{array}$ \\
\hline KRL & Coeficiente de perda de carga no ralo da piscina & Somente usado se $\mathrm{KAC}=2(\mathrm{KRL}=1,4)$ \\
\hline $\mathrm{KBH}$ & Coeficiente de perda de carga no tubo de irradiação & $\begin{array}{c}\text { Somente usado se } \mathrm{NAC}=5(\mathrm{KBH}=0)-\text { Forma } \\
\text { conservativa }\end{array}$ \\
\hline HMIN & Altura do tubo de irradiação relativa ao fundo da piscina & Somente usado se NAC $=5(\mathrm{HMIN}=1,591 \mathrm{~m})$ \\
\hline $\mathrm{KDF}$ & Coeficiente de perda de carga no difusor & Somente usado se $\mathrm{NAC}=3(\mathrm{KDF}=150)$ \\
\hline KVB & Coeficiente de perda de carga na válvula de isolamento & Somente usado se $\mathrm{NAC}=3(\mathrm{KVB}=0,1)$ \\
\hline KTEE & Coeficiente de perda de carga no "T" do difusor & Somente usado se $\mathrm{NAC}=3(\mathrm{KTEE}=1)$ \\
\hline HDB & Altura de desligamento da bomba por nível de água baixo & Somente usado se $\mathrm{NAC}=3(\mathrm{HDB}=8,4 \mathrm{~m})$ \\
\hline $\mathrm{ADF}$ & Área da seção transversal do difusor & Somente usado se $\mathrm{NAC}=3\left(\mathrm{ADF}=1,667 \mathrm{~m}^{2}\right)$ \\
\hline ATUB & Área da seção transversal da tubulação na ruptura & Somente usado se $\mathrm{NAC}=3\left(\mathrm{ATUB}=0,056 \mathrm{~m}^{2}\right)$ \\
\hline
\end{tabular}


Tabela 14 - Dados de entrada do programa LOSS: Ruptura dos tubos do SPI.

\begin{tabular}{|c|c|}
\hline \hline Dados de Entrada & Opção ou Valor Adotado \\
\hline \hline NAC & 1 \\
DT & $2 \mathrm{~s}$ \\
TMAX & $10000 \mathrm{~s}$ \\
APIS & $28,737 \mathrm{~m}^{2}$ \\
H & $11,5 \mathrm{~m}$ \\
HAP & $8,8 \mathrm{~m}$ \\
FCV & 1,1 \\
DRUP & 0,045 \\
NT & 4 \\
\hline
\end{tabular}

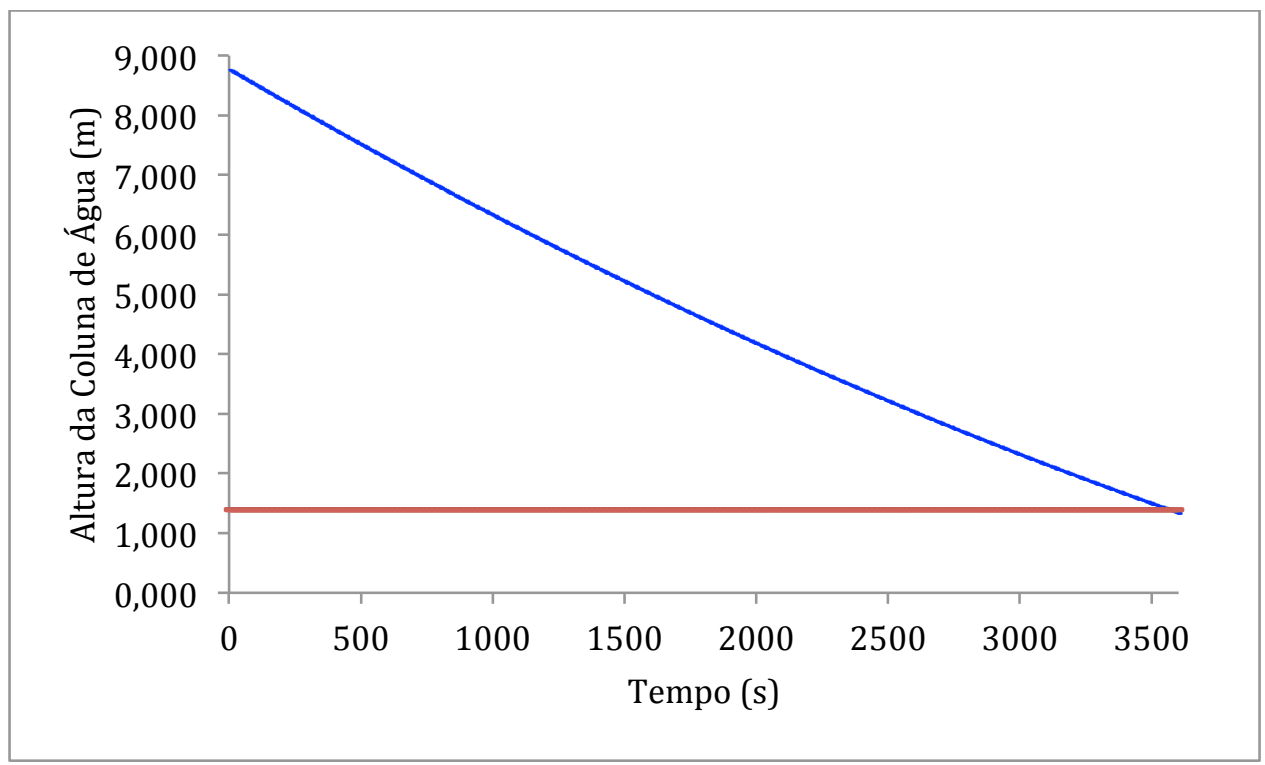

Figura 65 - Descobrimento do Núcleo - Ruptura dos Tubos SPI (linha vermelha: Altura na qual o núcleo se encontra completamente descoberto, $1,396 \mathrm{~m})$.

\subsection{2 - Falhas nos Drenos da Piscina - Ruptura dos Tubos de Acesso SRA}

As duas saídas de drenos existentes na piscina, localizadas respectivamente no compartimento do reator e no compartimento de estocagem, são ligadas ao SRA por tubulações de aço inoxidável.

A saída do dreno do compartimento de estocagem permanece aberta e acoplada a uma mangueira com um coletor de água com boia que que possui o seu curso limitado por um cabo de aço de 8,7m [40]. Existem dois casos de acidentes que podem ser considerados: 
1. A ruptura da tubulação de dreno à jusante da união das duas tubulações dos drenos que causaria um vazamento de água da piscina até o travamento da boia de aspiração e posterior fechamento da válvula de isolamento do dreno do compartimento de estocagem;

2. O caso mais crítico, que se daria com o desprendimento do volante de inércia da bomba e consequente choque com a tubulação, levando à ruptura da mesma à montante da válvula de isolamento de dreno do compartimento do reator, onde se teria o esvaziamento incontrolável da água da piscina.

A Tabela 15 apresenta os dados de entrada par ao caso de um APR por ruptura dos tubos de acesso SRA. A Fig. 67 mostra a variação do nível de água da piscina em função do tempo, calculada com o programa LOSS para o caso mais crítico.

Tabela 15 - Dados de entrada do programa LOSS: Ruptura dos tubos de acesso SRA.

\begin{tabular}{|c|c|}
\hline \hline Dados de Entrada & Opção ou Valor Adotado \\
\hline NAC & 2 \\
DT & $2 \mathrm{~s}$ \\
TMAX & $20000 \mathrm{~s}$ \\
APIS & $28,737 \mathrm{~m}^{2}$ \\
H & $11,5 \mathrm{~m}$ \\
HAP & $8,8 \mathrm{~m}$ \\
FCV & 1,1 \\
DRUP & $0,0525 \mathrm{~m}$ \\
KCV & 2,85 \\
KRL & 1,4 \\
\hline
\end{tabular}




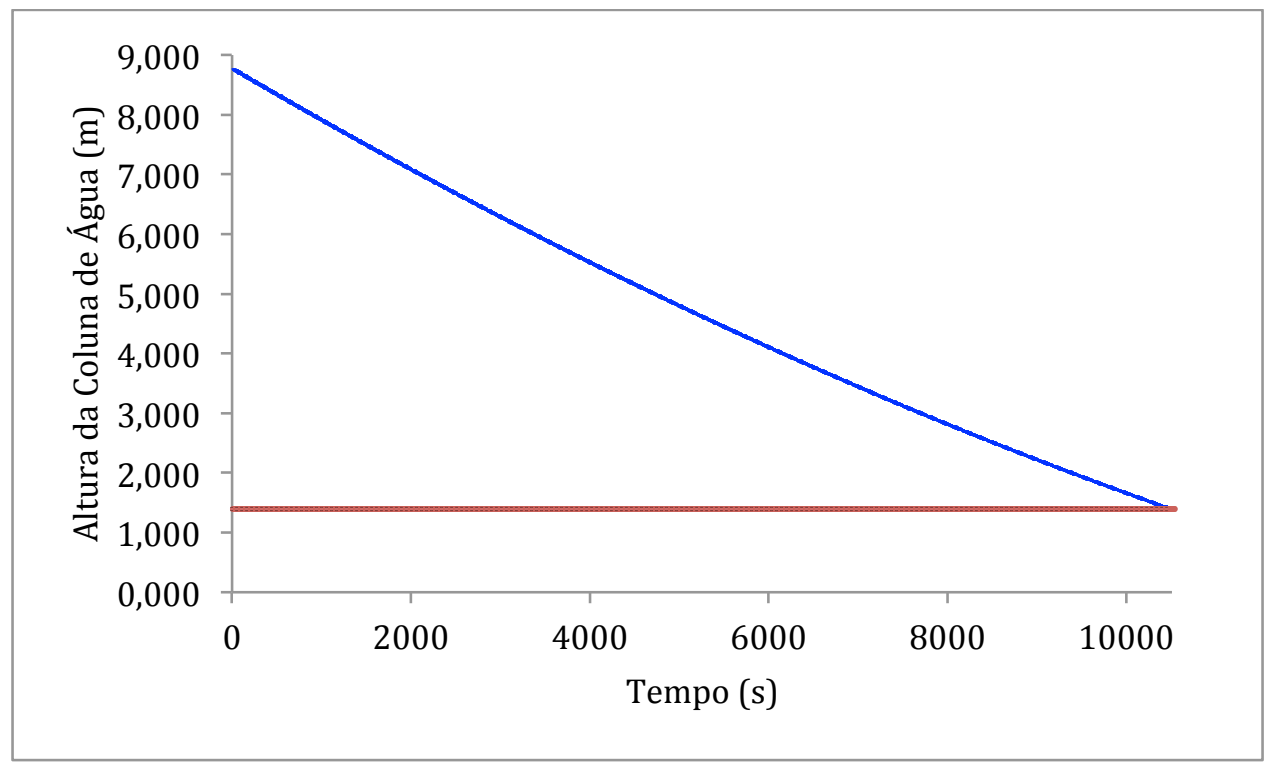

Figura 66 - Descobrimento do Núcleo - Ruptura dos Tubos de acesso SRA (linha vermelha: Altura na qual o núcleo se encontra completamente descoberto, 1,396m).

\subsection{3 - Ruptura da Fronteira do Circuito Primário}

O circuito primário é composto pela tubulação de retorno do refrigerante primário que fica próxima à piscina. Ele opera a baixas pressões e temperaturas, de forma que uma ruptura tipo guilhotina em sua tubulação se daria apenas por um forte impacto externo.

Como a probabilidade de ocorrências de terremotos ou quedas de aviões são muito baixas, então a causa mais provável de ruptura do circuito primário seria devido ao desprendimento do volante de inércia das bombas desse sistema.

O primário conta com duas válvulas de isolamento manuais, localizadas no porão do prédio, respectivamente à entrada e à saída da piscina.

A Tabela 16 apresenta os dados de entrada para o caso de um APR por ruptura da fronteira do circuito primário do reator IEA-R1 e a Fig. 68, a variação do nível de água em função do tempo. 
Tabela 16 - Dados de entrada do programa LOSS: Ruptura da fronteira do circuito primário.

\begin{tabular}{|c|c|}
\hline \hline Dados de Entrada & Opção ou Valor Adotado \\
\hline NAC & 3 \\
DT & $2 \mathrm{~s}$ \\
TMAX & $500 \mathrm{~s}$ \\
APIS & $28,737 \mathrm{~m}^{2}$ \\
H & $11,5 \mathrm{~m}$ \\
HAP & $8,8 \mathrm{~m}$ \\
FCV & 1,1 \\
DRUP & $0,267 \mathrm{~m}$ \\
KCV & 0,42 \\
KDF & 150 \\
KVB & 0,1 \\
KTEE & 1,0 \\
HDB & $8,4 \mathrm{~m}$ \\
ADF & $1,667 \mathrm{~m}^{2}$ \\
ATUB & $0,056 \mathrm{~m}^{2}$ \\
\hline
\end{tabular}

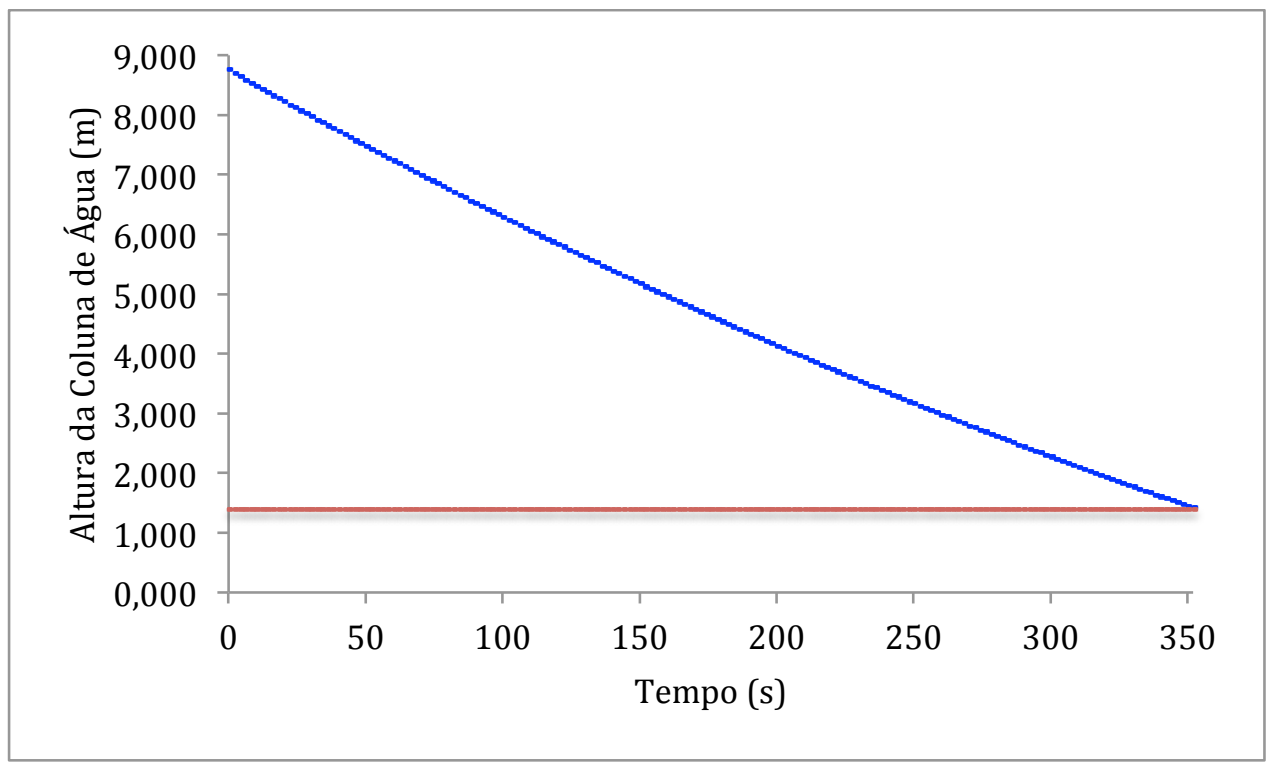

Figura 67 - Descobrimento do Núcleo - Ruptura da fronteira do circuito primário (linha vermelha: Altura na qual o núcleo se encontra completamente descoberto, 1,396m).

\subsection{4 - Abertura Indevida dos Drenos do SRA}

O SRA (sistema de retratamento de água) é composto por dois circuitos de tratamento, sendo que cada um deles conta com seis válvulas de dreno. A abertura indevida dos drenos do SRA se daria através de sabotagem, cuja probabilidade de ocorrência é baixa, devido aos procedimentos e dispositivos de segurança da instalação, restringindo o acesso de pessoas estranhas ao prédio do reator e até mesmo dos operadores ao porão, onde se localizam os drenos. 
A divisão de Análise de Segurança solicitou duas medidas para evitar o esvaziamento acidental da piscina pelos drenos, sendo adotadas pelo CRPq do IPEN/CNEN-SP:

1. O travamento da válvula de isolamento do SRA com um cadeado;

2. O travamento da boia da mangueira de coleta de água da piscina através de um cabo de aço com $8,7 \mathrm{~m}$.

A Tabela 17 apresenta os dados de entrada para o caso em questão (abertura indevida dos drenos do SRA) e a Fig. 69, a variação do nível de água em função do tempo.

Tabela 17 - Dados de entrada do programa LOSS: Ruptura da fronteira do circuito primário.

\begin{tabular}{|c|c|}
\hline Dados de Entrada & Opção ou Valor Adotado \\
\hline NAC & 4 \\
DT & $2 \mathrm{~s}$ \\
TMAX & $50000 \mathrm{~s}$ \\
APIS & $28,737 \mathrm{~m}^{2}$ \\
H & $11,5 \mathrm{~m}$ \\
HAP & $8,8 \mathrm{~m}$ \\
FCV & 1,1 \\
\hline
\end{tabular}

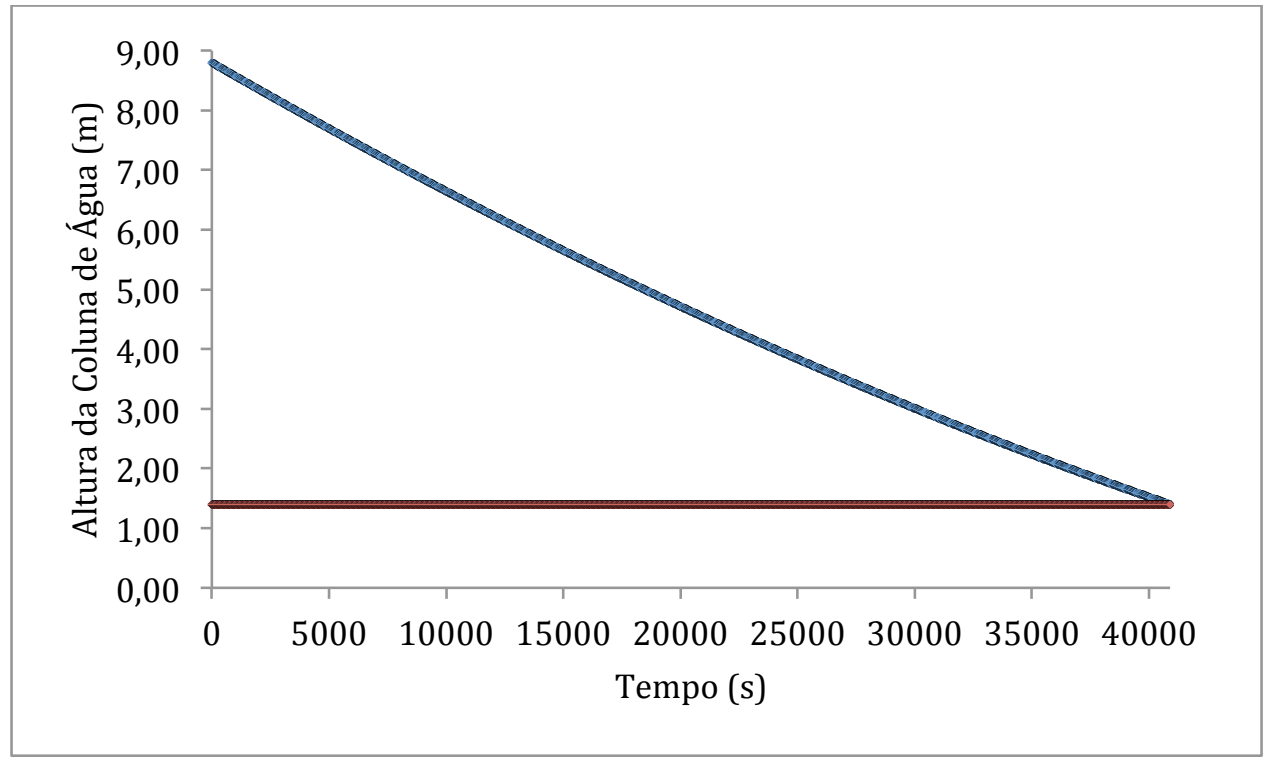

Figura 68 - Descobrimento do Núcleo - Abertura indevida dos drenos do SRA (linha vermelha: Altura na qual o núcleo se encontra completamente descoberto, 1,396m). 


\subsection{5 - Falha nos Tubos Colimadores (BH-3)}

O reator IEA-R1 possui onze tubos de alumínio (Beam Holes) para a realização de experimentos. Os tubos atravessam horizontalmente as paredes de concreto da piscina em doze pontos. Os tubos estão posicionados em alturas diferentes relativamente ao núcleo, de forma que apenas o rompimento do $\mathrm{BH}-3$ descobriria a parte ativa das miniplacas.

Caso ocorra o rompimento dos demais BHs, o nível de água da piscina permaneceria acima da parte ativa do núcleo, garantindo a resfriamento forçada através da bomba principal. A Tabela 18 apresenta os dados de entrada para a falha nos tubos colimadores (BH-3) e a Fig. 70, a variação do nível de água em função do tempo

Tabela 18 - Dados de entrada do programa LOSS: Falha nos tubos colimadores (BH-3).

\begin{tabular}{|c||c|}
\hline \hline Dados de Entrada & Opção ou Valor Adotado \\
\hline NAC & 5 \\
DT & $2 \mathrm{~s}$ \\
TMAX & $20000 \mathrm{~s}$ \\
APIS & $28,737 \mathrm{~m}^{2}$ \\
HAP & $8,8 \mathrm{~m}$ \\
FCV & 1,1 \\
DRUP & $0,2 \mathrm{~m}$ \\
NT & 1 \\
KBH & 0 \\
HMIN & 1,591 \\
\hline
\end{tabular}

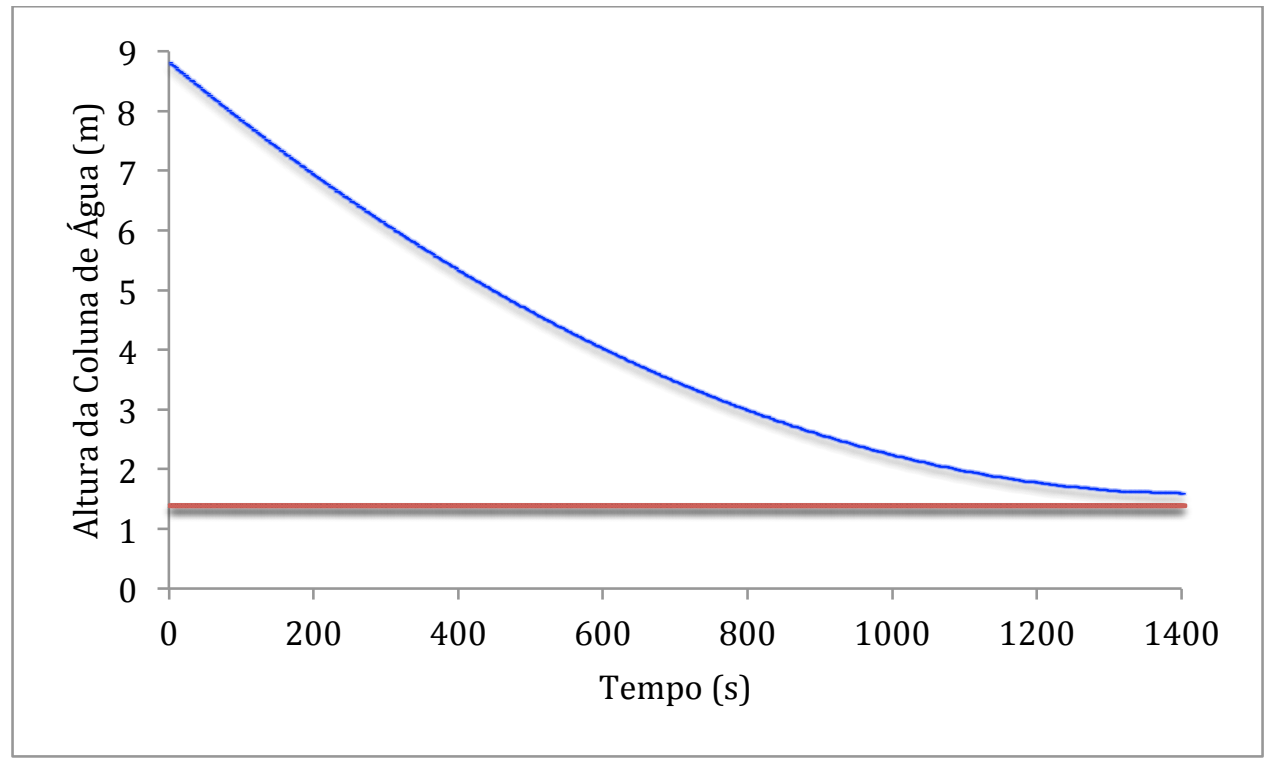

Figura 69 - Descobrimento do Núcleo - Falha nos tubos colimadores [BH-3] (linha vermelha: Altura na qual o núcleo se encontra completamente descoberto, 1,396m). 
Dos cinco acidentes postulados e analisados, verifica-se que a ruptura da fronteira do primário é o mais crítico, pois possui o menor tempo hábil para se tomar alguma atitude, cerca de aproximadamente 6 minutos, uma vez que esse é o tempo gasto para toda a água da piscina deixar a parte ativa do núcleo do reator.

\section{4 - O Programa TEMPLOCA e a Temperatura Máxima Atingida}

Após um acidente de perda de refrigerante, o calor de decaimento dos produtos de fissão tendem a aumentar a temperatura do combustível nuclear.

Em contrapartida, a capacidade térmica dos elementos combustíveis e os mecanismos de transferência de calor tendem a reduzir a temperatura do núcleo. Esse balanço energético está expresso na Eq. 58.

$$
M c_{P} \frac{d \theta(t)}{d t}=Q(t)-U A \theta(t)
$$

onde $Q(t)$ é o calor de decaimento, $M$ é a massa do combustível, $c_{P}$ é o calor específico do elemento combustível, $U A$ é a condutância térmica global, que corresponde ao produto do coeficiente global de transferência de calor $U$ pela área de troca térmica $A$ e $\theta(t)$ é a diferença entre a temperatura do combustível e a temperatura média do ar (atente-se ao fato de que o núcleo já se encontra descoberto). A Eq. 58 permite calcular a temperatura do combustível como função do tempo, após o desligamento do reator.

Entretanto, a experiência tem demonstrado que um cálculo preciso da condutância térmica global $U A$ não é possível pelo uso dos princípios de transferência de calor básicos, devido aos complicados caminhos da condução de calor e as incertezas nas aproximações necessárias para descrever as perdas de calor por convecção no ar e radiação. A referência [40] mostra que a temperatura máxima alcançada nos elementos combustíveis pode ser determinada com razoável precisão utilizando um coeficiente de transferência de calor ajustado, conforma mostra a Eq. 59. 


$$
h=C\left(0,0064 \theta(t)^{0,72}+0,5\right)
$$

Utilizando os dados dos experimentos discutidos na referência [40], pode-se aplicar ao IEA-R1 a mesma metodologia, encontrando assim resultados conservativos para a simulação do APR. Dessa forma, a condutância térmica global pode ser calculada através da seguinte expressão [41]:

$$
U A=1,3 \cdot 10^{-6}\left(6,4 \cdot 10^{-3} \theta(t)^{0,72}+0,5\right)
$$

e substituindo na Eq. 58, tem-se

$$
M c_{P} \frac{d \theta(t)}{d t}=Q(t)-1,3 \cdot 10^{-6}\left(6,4 \cdot 10^{-3} \theta(t)^{0,72}+0,5\right) \theta(t)
$$

O fator $Q(t)$, com dimensão de potência relativa (razão entre a potência atual e a potência de operação) e referente ao calor de decaimento, pode ser calculado através da equação de Way-Wigner [40]:

$$
Q(t)=W\left[t^{-0,2}-(T+t)^{-0,2}\right]
$$

onde $W$ é uma constante que depende do material, $t$ é o tempo de decaimento e $T$ é o tempo de irradiação. A determinação da temperatura máxima com o tempo é calculada com o programa TEMPLOCA [40], desenvolvido pelo IPEN/CNEN-SP. A Tabela 19 apresenta a relação dos dados de entrada desse programa. 
Tabela 19 - Dados de entrada do programa TEMPLOCA.

\begin{tabular}{|c|c|}
\hline $\begin{array}{l}\text { Dados de } \\
\text { Entrada }\end{array}$ & Descrição \\
\hline PM & Potência de operação por elemento combustível (MW) \\
\hline TMAX & Tempo máximo de transiente (s) \\
\hline TLAG & Tempo entre o desligamento do reator e o descobrimento do núcleo \\
\hline TIFC & Temperatura do combustível no instante inicial após o descobrimento $\left({ }^{\circ} \mathrm{C}\right)$ \\
\hline TARC & Temperatura inicial do ar após o descobrimento $\left({ }^{\circ} \mathrm{C}\right)$ \\
\hline FR & Fator de potência radial do elemento analisado \\
\hline FS & Fator de incerteza para a potência de decaimento \\
\hline FSP & Fator de sobrepotência \\
\hline IMCP & $\begin{array}{l}\text { Opção de entrada para a massa e o calor específico do elemento combustível } \\
\text { IMCP=1Utilização do fator de correção FMCP } \\
\text { IMCP=2 Fornecimento das massas do elemento e cálculo do calor específico } \\
\text { em função da temperatura (somente para combustíveis } \mathrm{U}_{3} \mathrm{O}_{8} \text { ) }\end{array}$ \\
\hline FMCP & $\begin{array}{l}\text { Fator de correção da massa e do calor específico em relação ao valor padrão } \\
\text { do elemento combustível de controle do reator LITR } \\
\text { Somente usado se IMCP }=1 \text { e FMCP }=1,0\end{array}$ \\
\hline MAL & Massa do alumínio do elemento combustível $(\mathrm{kg})$ \\
\hline MFU & Massa da dispersão de $\mathrm{U}_{3} \mathrm{O}_{8}-\mathrm{Al}$, somente usado se $\mathrm{IMCP}=2$ \\
\hline WU & Fração em peso de urânio na dispersão, somente usado se IMCP=2 \\
\hline ICDEC & $\begin{array}{l}\text { Opção para escolha da curva de decaimento. Way-Wigner ICDEC }=1 \\
\text { Equação do decaimento exponencial ICDEC }=2\end{array}$ \\
\hline TO & Tempo de operação do reator anterior ao seu desligamento (s) \\
\hline $\mathrm{W}$ & Constante dependente do material combustível. Somente usado se ICDEC=1 \\
\hline COEFICIENTES & Coeficientes da equação do decaimento exponencial. Somente usado se ICDEC $=2$ \\
\hline
\end{tabular}

\subsection{1 - Temperatura Atingida após o APR}

Em casos de ocorrência de um APR, os combustíveis (parte ativa do núcleo) ficariam sem resfriamento após o descobrimento do núcleo. Diferentemente do que ocorre na análise termo-hidráulica, o calor a ser removido nesse caso é aquele referente ao decaimento dos produtos de físsão e não o gerado pelas fissões do U-235.

Dessa forma, o elemento combustível mais quente, ou seja, aquele que apresenta o maior fator de pico (ou potência) radial, deve ser analisado para verificar a temperatura máxima atingida num determinado núcleo frente a um cenário de APR e avaliar se as temperaturas atingidas estão dentro dos limites de projeto (lembrando que os elementos combustíveis são formados por placas de $\mathrm{U}_{3} \mathrm{Si}_{2}-\mathrm{Al}$ com densidade de $4,8 \mathrm{gU} / \mathrm{cm}^{3}$, envolvidos por um revestimento de Alumínio). 
A análise pode ser simplificada se considerarmos o elemento combustível mais quente dentre todos os núcleos novos apresentados, pois uma vez garantindo os limites de projeto para esse elemento, aqueles referentes aos demais núcleos e elementos combustíveis serão consequentemente obedecidos (a Fig. 71 ilustra o fator de potência radial para as configurações analisadas e a Tabela 20, o maior valor da potência máxima por placa combustível por configuração). Para efeitos de cálculo, admite-se que os núcleos operem a 120 horas semanais (na potência de 5MW) e também, a título de comparação, a 233 dias contínuos.

Dentre os cinco tipos de acidentes postulados para o reator IEA-R1 e analisados na seção anterior com o programa LOSS, verificou-se que o mais crítico é aquele onde se dá a ruptura da fronteira do circuito primário. Isso acontece pois o tempo para o esvaziamento completo da parte ativa do núcleo se dá em cerca de 6 minutos, sendo esse o menor tempo dentre os dos demais acidentes. A Tabela 21 apresenta os dados de entrada para o cálculo da temperatura nos elementos combustíveis com o programa TEMPLOCA.

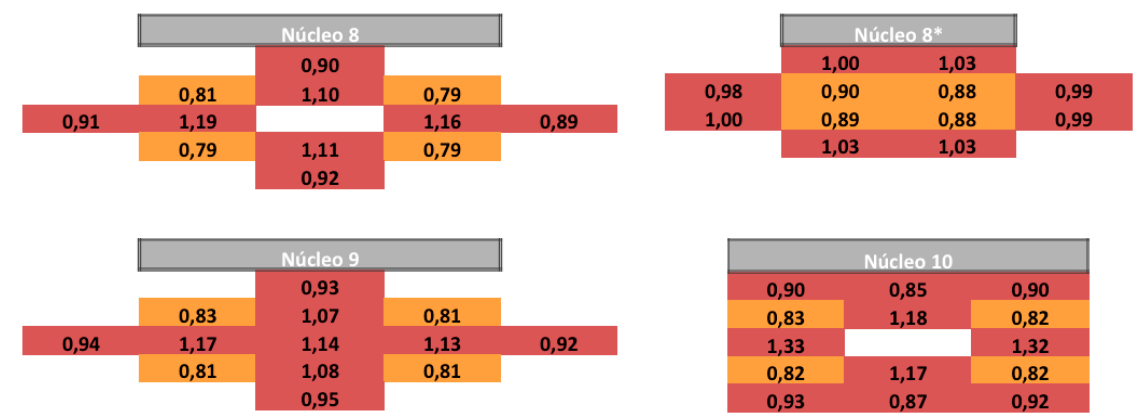

Figura 70 - Fator de potência radial para as configurações 8, 8*, 9 e 10 (a cor vermelha simboliza elemento combustível e a laranja, elemento de controle).

Tabela 20 - Potência média por placa combustível, Fator de potência radial e potência máxima por elemento.

\begin{tabular}{|c|c|c|c|c|}
\hline & Núcleo 8 & Núcleo $8 *$ & Núcleo 9 & Núcleo 10 \\
\hline Potência Média/elemento (MW/elemento) & 0,41667 & 0,41667 & 0,38462 & 0,35714 \\
\hline Fator de Potência Radial & 1,19 & 1,03 & 1,17 & 1,33 \\
\hline Potência Máxima/elemento (MW/elemento) & 0,49584 & 0,42917 & 0,45001 & 0,47499 \\
\hline
\end{tabular}


Tabela 21 - Dados de entrada do programa TEMPLOCA para o cálculo da temperatura nas miniplacas do elemento mais quente dentre todos os núcleos apresentados.

\begin{tabular}{|c|c|}
\hline \hline PM & Opção ou Valores Adotados \\
\hline & Núcleo $8(0,41667)-$ Núcleo $8 *(0,41667)-$ \\
PM & Núcleo $9(0,38462)-$ Núcleo $10(0,35714)$ \\
TMAX & 60000 s \\
TLAG & 350s - Mais estudos paramétricos em TLAG \\
FR & Núcleo: $8(1,19) 8^{*}(1,03) 9(1,17) 10(1,33)$ \\
FS & 1,1 \\
FSP & 1,1 \\
IMCP & 1 \\
FMCP & 1,0 \\
TIFC & $100^{\circ} \mathrm{C}$ \\
TARC & $32{ }^{\circ} \mathrm{C}$ \\
ICDEC & 1 \\
TO & $432000 \mathrm{~s}(120 \mathrm{~h})-20131200 \mathrm{~s}(233 \mathrm{~d})$ \\
W & 0,0622 \\
&
\end{tabular}

A Fig. 72 ilustra o estudo paramétrico (em TLAG) realizado para cada novo núcleo para a determinação do tempo seguro de esvaziamento da piscina do reator do núcleo 8 , sendo repetido para obter os resultados das figuras Fig. 73-84, que mostram a temperatura máxima atingida nos elementos combustíveis mais quentes para as configurações $8,8^{*}, 9$ e 10 .

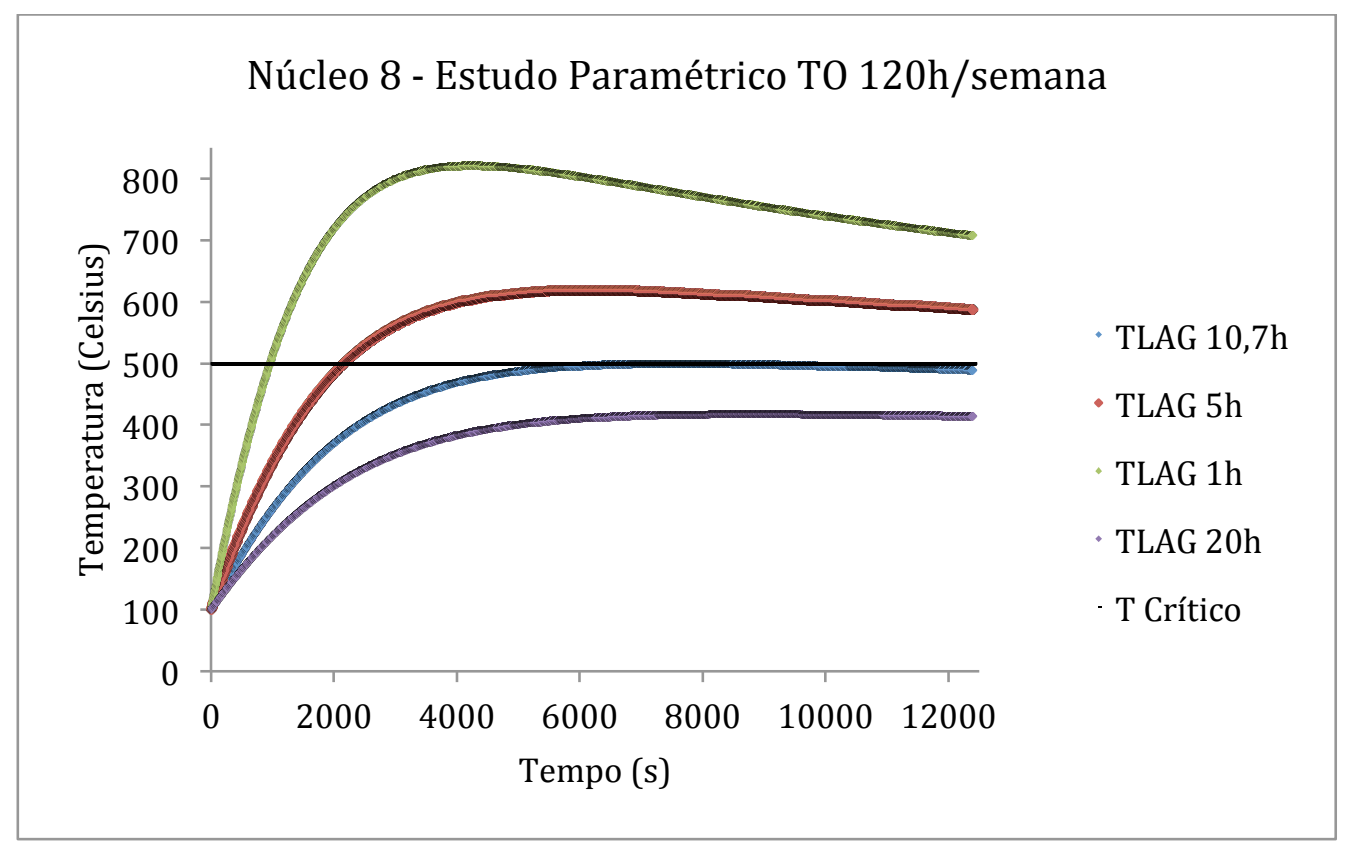

Figura 71 - Estudo paramétrico em TLAG para o núcleo 8. Metodologia para a determinação do tempo de esvaziamento seguro do núcleo. 


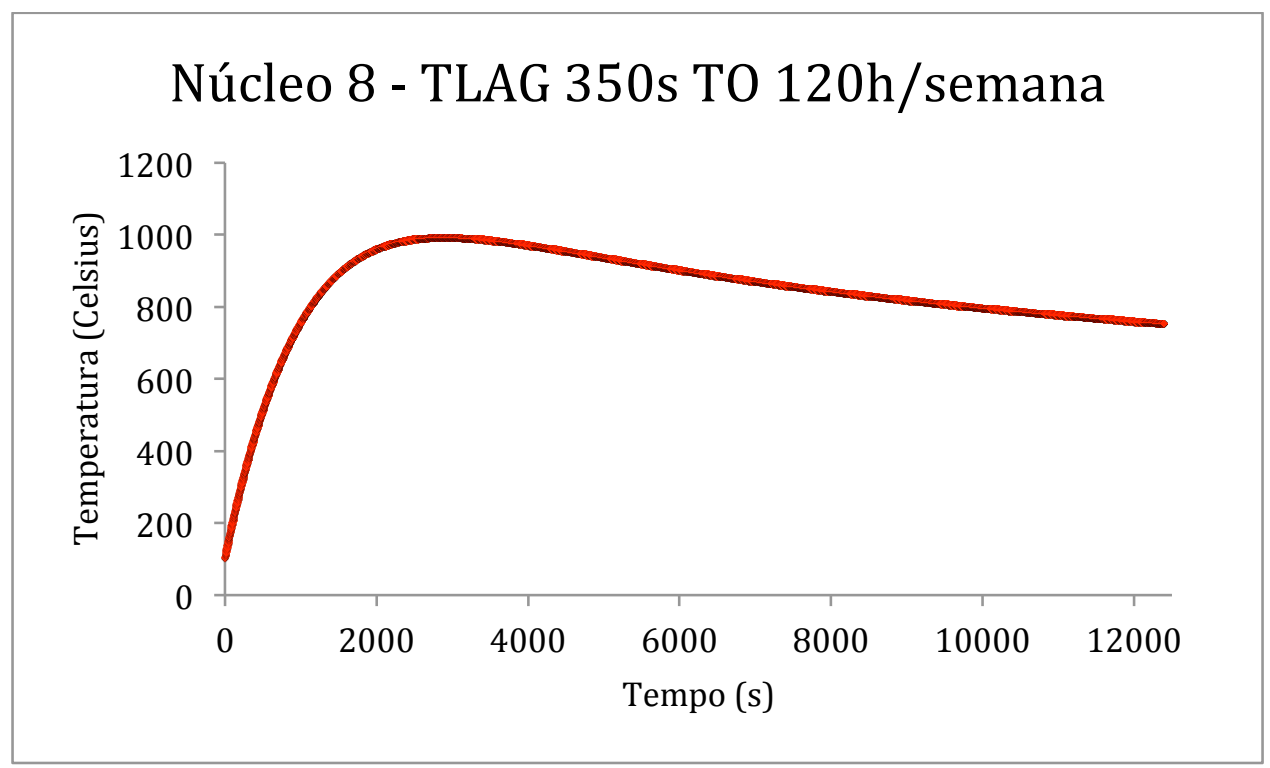

Figura 72 - Temperaturas atingidas após o descobrimento total do núcleo 8, referente ao caso mais extremo de esvaziamento da piscina (350s), via ruptura da fronteira do primário, operando $120 \mathrm{~h} / \mathrm{semana}$.

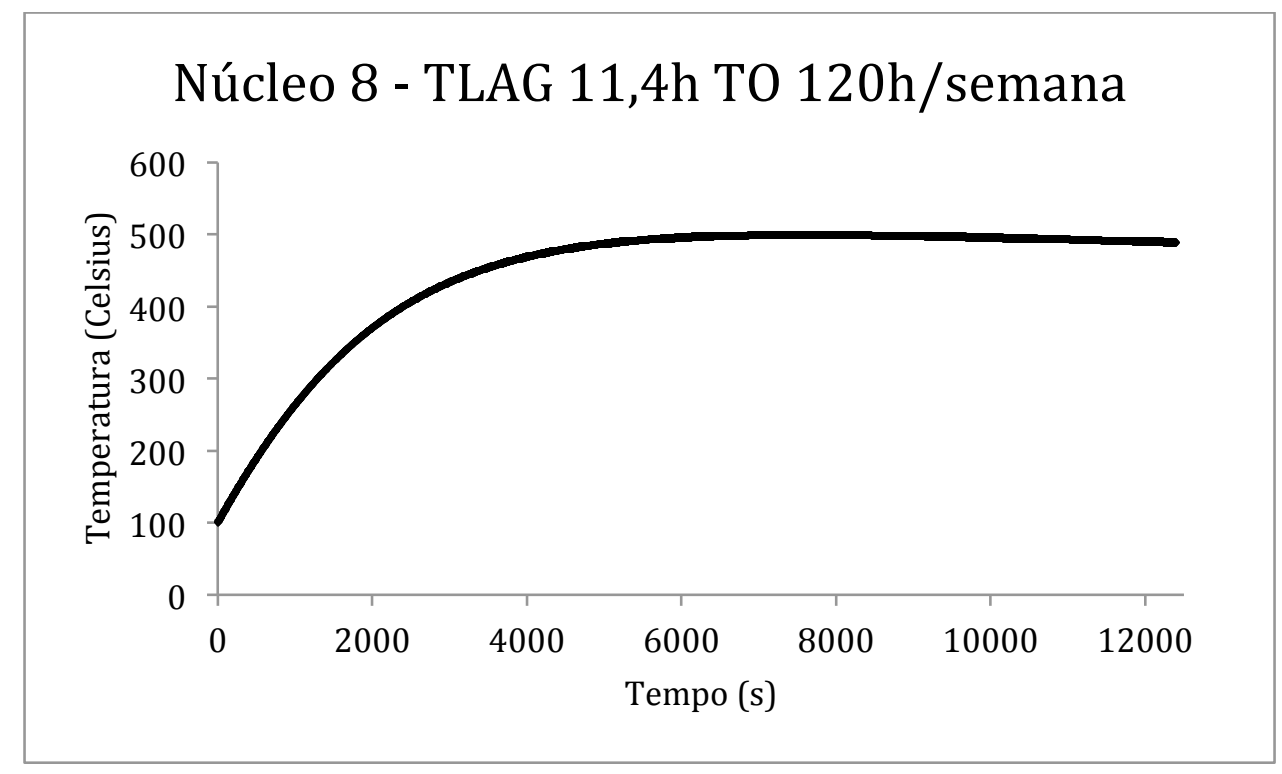

Figura 73 - Temperaturas atingidas após o descobrimento total do núcleo 8, operando $120 \mathrm{~h} / \mathrm{semana}$. Tempo de esvaziamento seguro igual a $11,4 \mathrm{~h}$. 


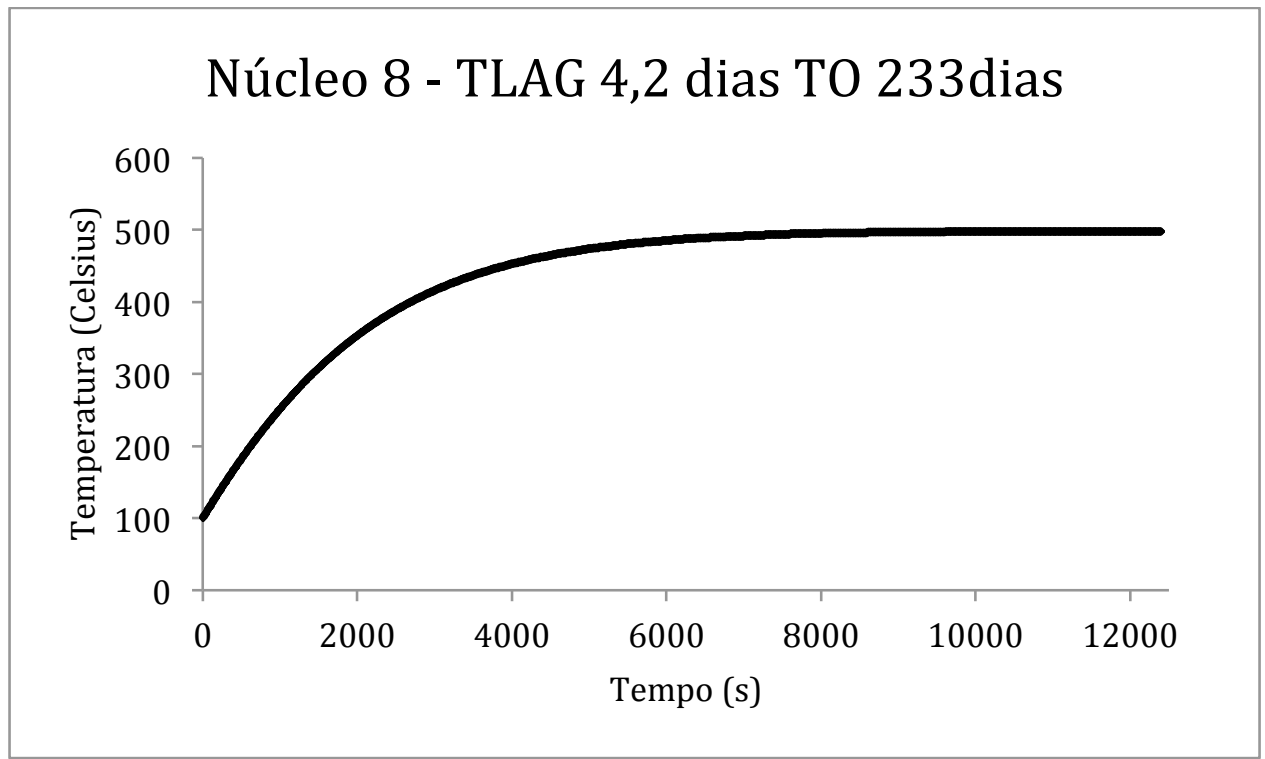

Figura 74 - Temperaturas atingidas após o descobrimento total do núcleo 8, operando 233 dias contínuos. Tempo de esvaziamento seguro igual a 4,2 dias.

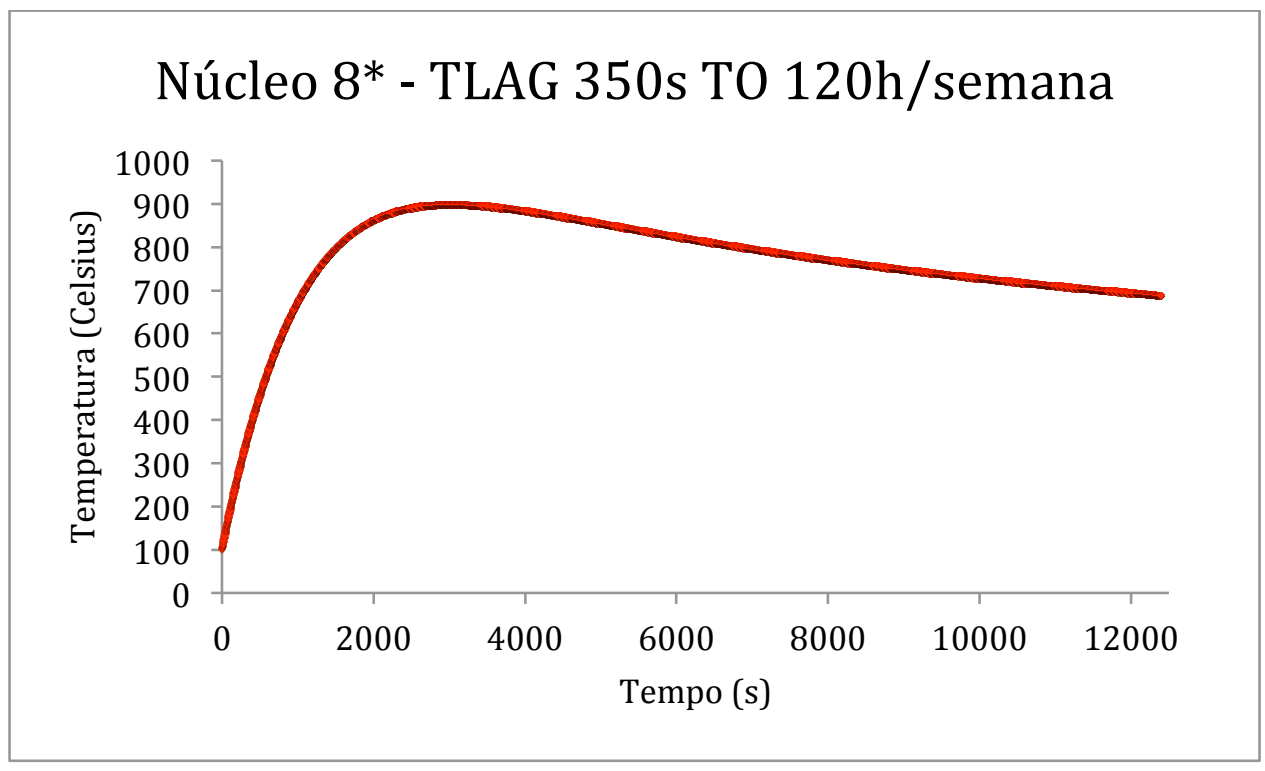

Figura 75 - Temperaturas atingidas após o descobrimento total do núcleo $8^{*}$, referente ao caso mais extremo de esvaziamento da piscina (350s), via ruptura da fronteira do primário, operando $120 \mathrm{~h} / \mathrm{semana}$. 


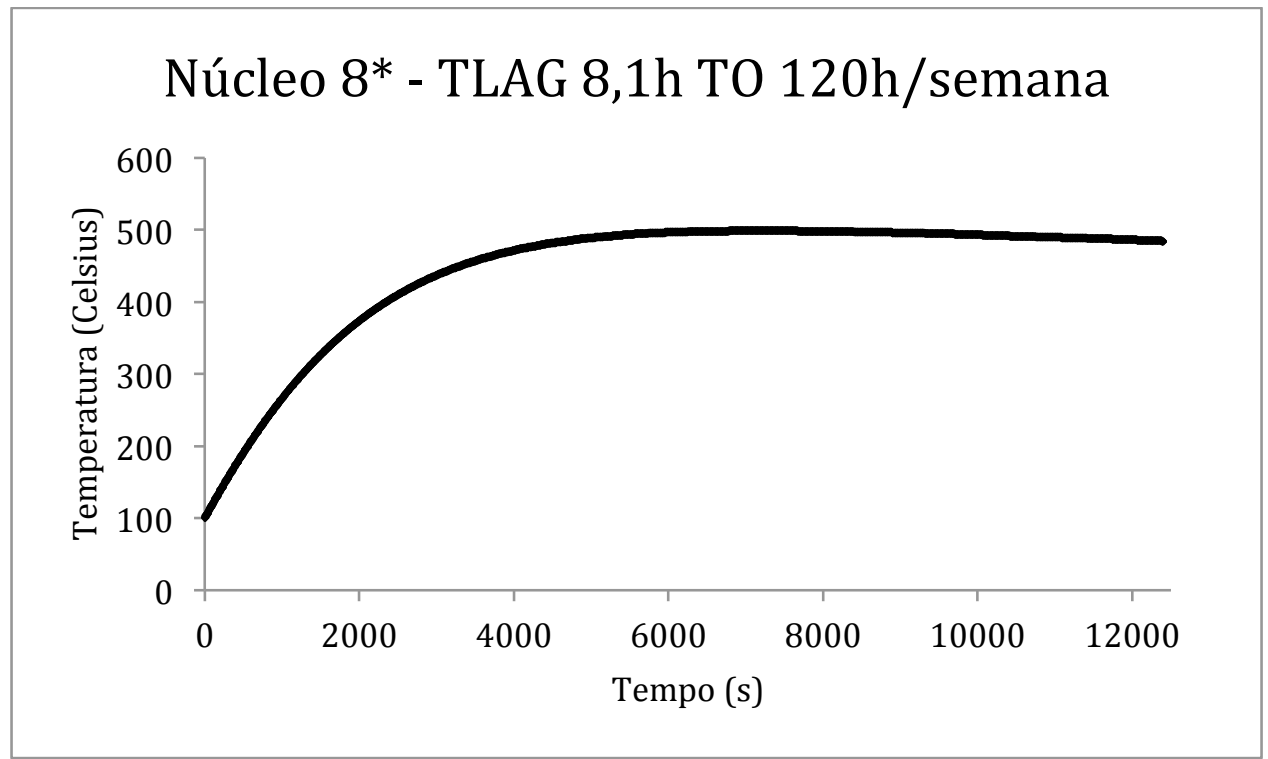

Figura 76 - Temperaturas atingidas após o descobrimento total do núcleo 8*, operando $120 \mathrm{~h} /$ semana. Tempo de esvaziamento seguro igual a $8,1 \mathrm{~h}$.

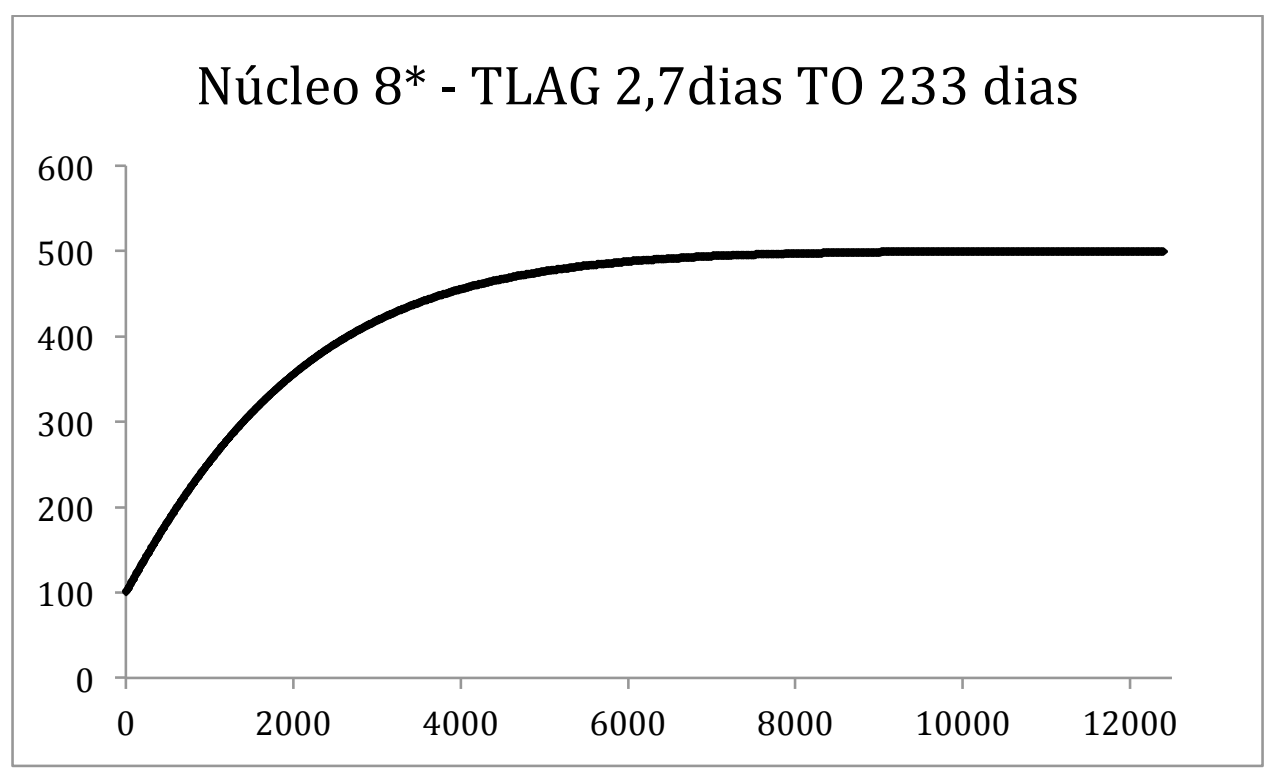

Figura 77 - Temperaturas atingidas após o descobrimento total do núcleo $8^{*}$, operando 233 dias contínuos. Tempo de esvaziamento seguro igual a 2,7 dias. 


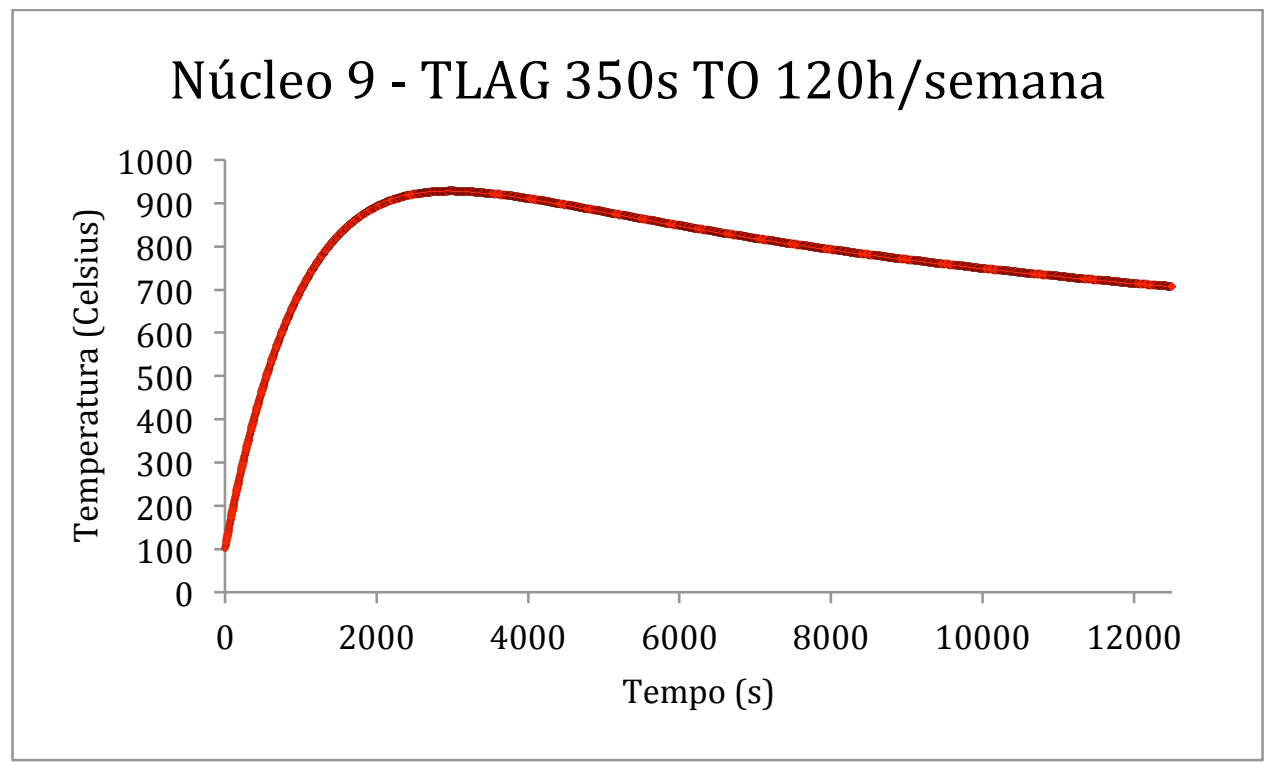

Figura 78 - Temperaturas atingidas após o descobrimento total do núcleo 9, referente ao caso mais extremo de esvaziamento da piscina (350s), via ruptura da fronteira do primário, operando $120 \mathrm{~h} /$ semana.

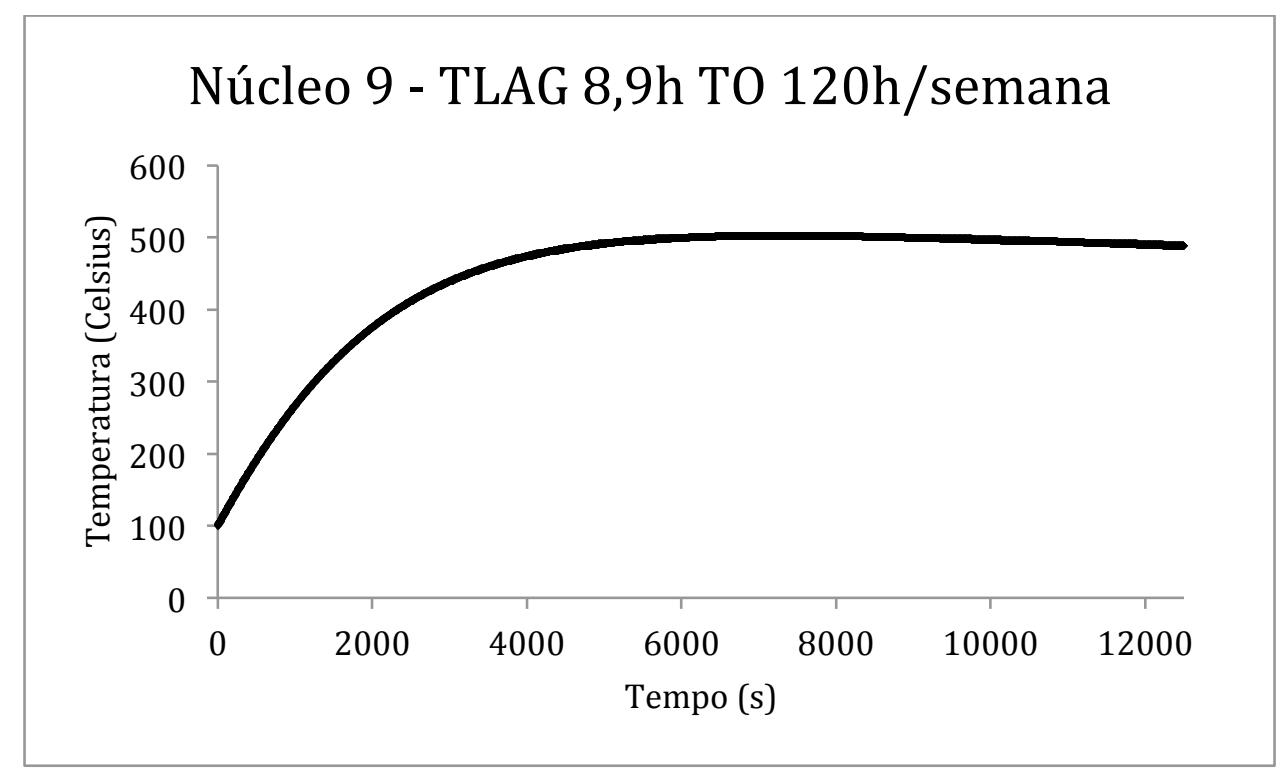

Figura 79 - Temperaturas atingidas após o descobrimento total do núcleo 9, operando $120 \mathrm{~h} / \mathrm{semana}$. Tempo de esvaziamento seguro igual a $8,9 \mathrm{~h}$. 


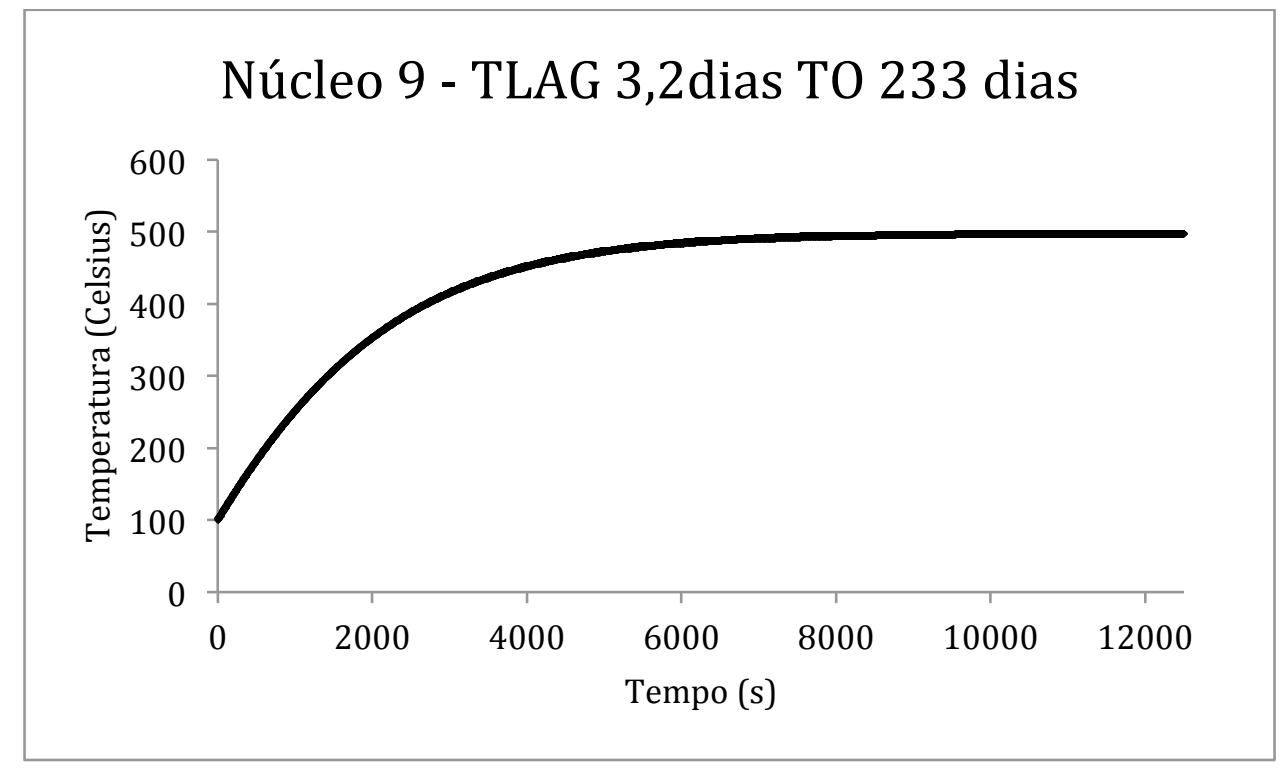

Figura 80 - Temperaturas atingidas após o descobrimento total do núcleo 9, operando 233 dias contínuos. Tempo de esvaziamento seguro igual a 3,2 dias.

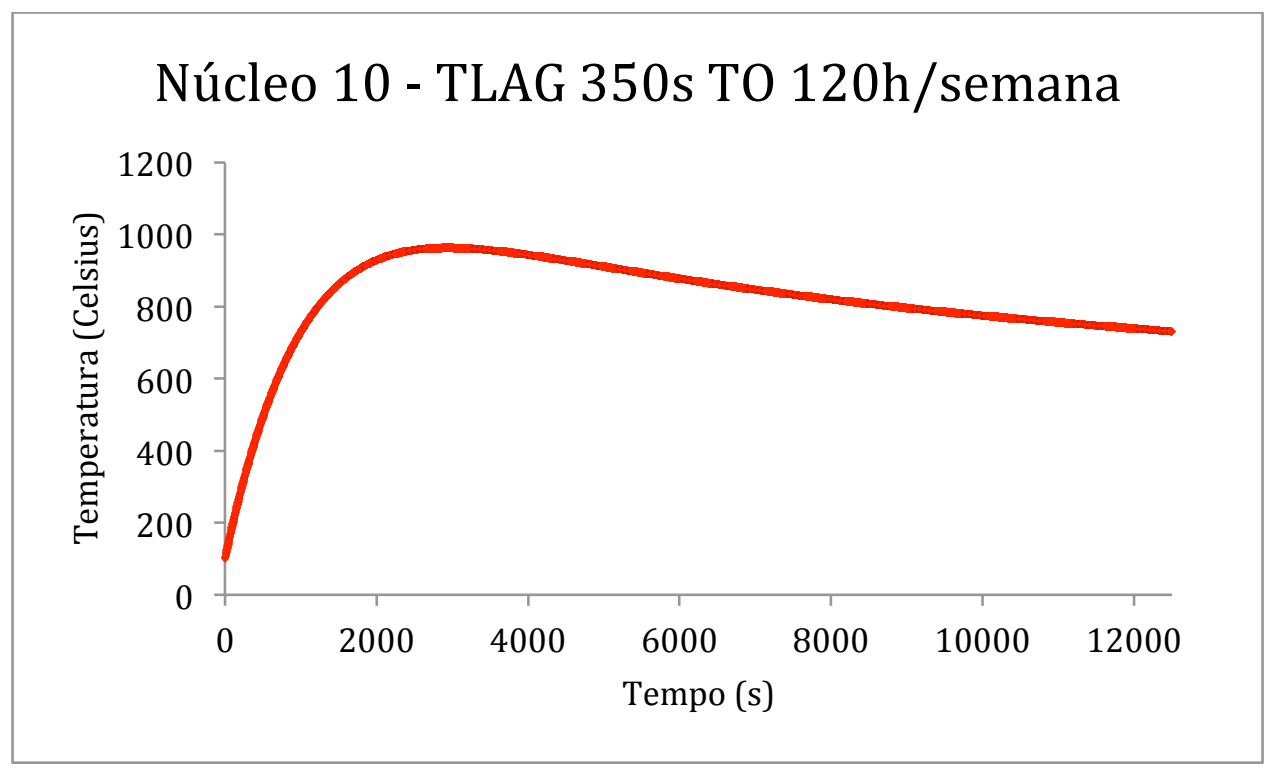

Figura 81 - Temperaturas atingidas após o descobrimento total do núcleo 10, referente ao caso mais extremo de esvaziamento da piscina (350s), via ruptura da fronteira do primário, operando $120 \mathrm{~h} / \mathrm{semana}$. 


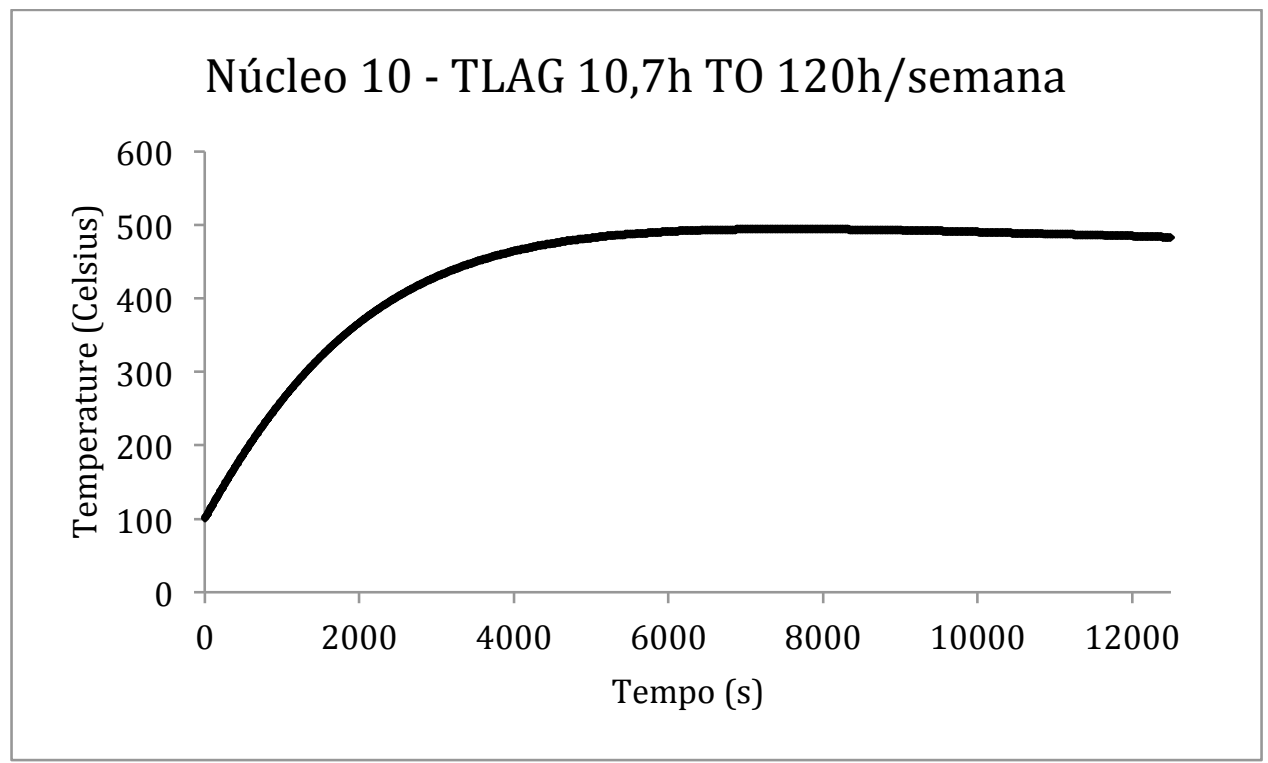

Figura 82 - Temperaturas atingidas após o descobrimento total do núcleo 10, operando $120 \mathrm{~h} /$ semana. Tempo de esvaziamento seguro igual a 10,7h.

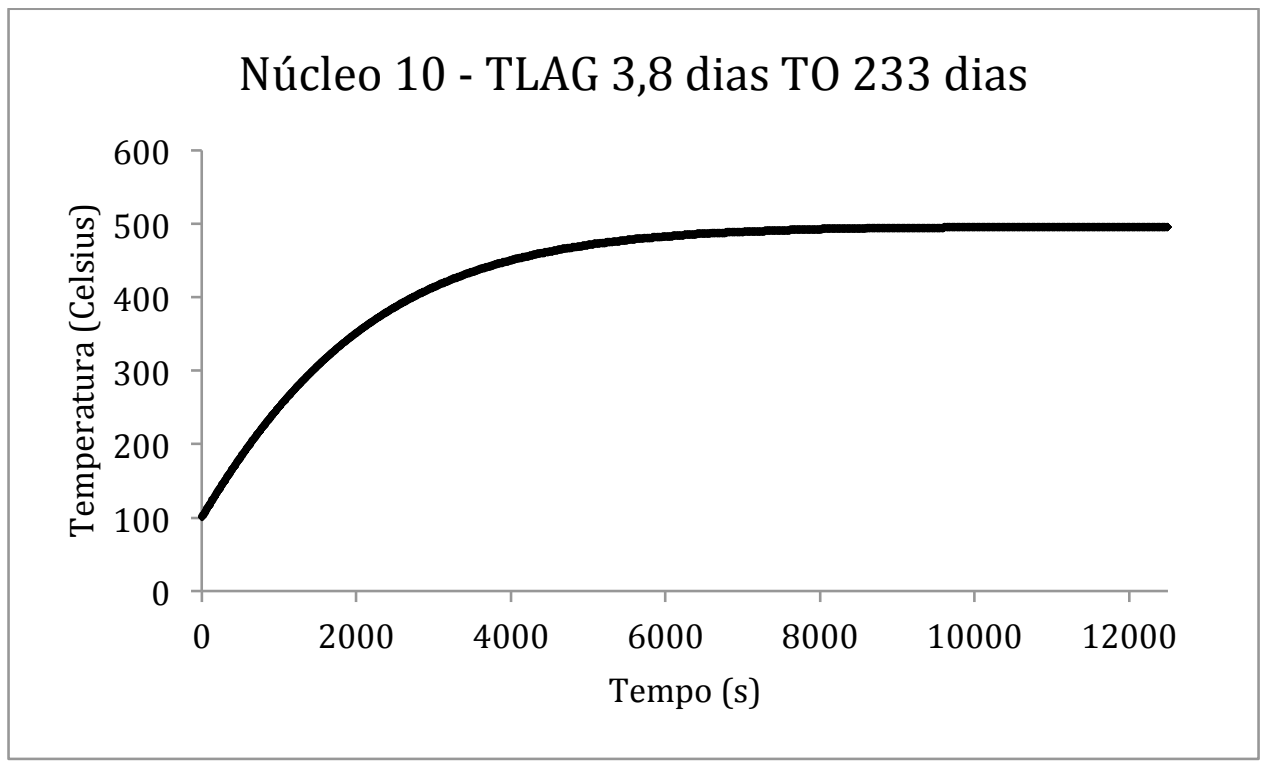

Figura 83 - Temperaturas atingidas após o descobrimento total do núcleo 10, operando 233 dias contínuos. Tempo de esvaziamento seguro igual a 3,8 dias. 


\section{Novos Núcleos para o Reator IEA-R1: Comentários e Discussões dos Resultados}

Neste capítulo, os resultados obtidos nas seções anteriores são comentados e discutidos. A discussão é dividida entre os três assuntos principais, para mostrar a existência de configurações menores para o reator IEA-R1: Análise neutrônica, termo-hidráulica e de segurança, respondendo-se as questões presentes na introdução deste trabalho.

\section{1 - Análise Neutrônica}

A análise neutrônica permitiu analisar e construir diversas novas configurações para o núcleo do reator nuclear IEA-R1. Foi através da modelagem computacional e da solução da equação de transporte (Eq. 1), via método Monte Carlo, que as demais análises se fizeram possíveis. Através dessa análise, diversos parâmetros foram determinados:

- A geometria dos novos núcleos, via software MCNP;

- A criticalidade e excesso de reatividade (considerando as barras de controle totalmente fora da região ativa do núcleo e também totalmente inseridas no mesmo);

- A margem de desligamento e o valor total dos elementos de controle (abordagem clássica e de segurança);

- O cálculo da densidade de potência e dos fatores de pico, que são dados de entrada para a análise termo-hidráulica.

Analisando esses parâmetros, conclui-se que nenhum dos núcleos possui restrições para submissão às demais etapas do estudo deste trabalho. Entretanto, vale pontuar aqui que as configurações menores, núcleo 5 , núcleo 6 e núcleo 7 apresentaram um baixo valor para $\mathrm{o}$ fator de multiplicação $\left(k_{\text {eff }}=1,00312, k_{\text {eff }}=1,01671, k_{\text {eff }}=1,03063\right.$ respectivamente) mesmo com as barras todas fora da região ativa dos referidos núcleos (esse fato é confirmado quando realizada a queima dos núcleo). 
O valor total dos elementos de controle, considerando uma das barras presas, (Tabela 2) é, para todas as configurações, duas vezes maior do que o excesso de reatividade dos núcleos (com as barras todas fora da região ativa), ou seja, mesmo se uma das barras, a de maior valor, ficar presa por algum motivo e não puder ser utilizada, os elementos de controle ainda conseguem inserir uma reatividade negativa no núcleo maior que duas vezes a reatividade existente (barras todas fora da região ativa).

Outro ponto importante é que, do ponto de vista de segurança e controle do reator, quando a barra de maior valor ficar presa fora da região ativa, as demais devem ser capaz de desligar o reator com uma boa margem de segurança. Essa margem de segurança varia de projeto para projeto e no caso do reator IEA-R1, utiliza-se o valor de $50 \%$. Observa-se que dentre os núcleos intermediários estudados $\left(8,8^{*}, 9\right.$ e 10$)$, somente os núcleos 8 e $8^{*}$ apresentam valores compatíveis para a essa margem. Entretanto, os demais poderiam ser utilizados, desde que esse fato fosse compensado através da utilização de algum tipo de veneno queimável, tornando segura a operação dos mesmos.

A Fig. 15, que ilustra a densidade de potência média em cada nova configuração, pode ser utilizada para estimar a ordem de grandeza do fluxo térmico de nêutrons. Mesmo o mapeamento de fluxos não sendo escopo desse trabalho, ter noção da ordem de grandeza dos mesmos é importante do ponto de vista de aplicações. Sabe-se que a densidade de potência é dada pela Eq. 8 e que uma aproximação desta, para se estimar o fluxo térmico é dado pela Eq. 63 (no caso de reatores térmicos)

$$
q^{\prime \prime \prime}(\vec{r}) \sim \mathrm{G} \Sigma(\overrightarrow{\mathrm{r}})_{f, \text { térmico }} \phi(\vec{r})_{\text {térmico }}
$$

Dessa forma, utilizando o valor médio de $\Sigma_{f, \text { térmico }}=0,159 \mathrm{~cm}^{-1}$, para combustíveis $\mathrm{U}_{3} \mathrm{Si}_{2}$ [42], assumindo o valor de $\mathrm{G}=200 \mathrm{Mev} /$ fissão e usando os dados da Fig. 15 para cada configuração, pode-se determinar, de forma estimada, o fluxo de nêutrons térmicos na região ativa dos núcleos (Tab. 22). 
Tabela 22 - Novos núcleos e os fluxos neutrônicos térmicos médios estimados na região ativa das novas configurações.

\begin{tabular}{|c|c|c|c|c|}
\hline Núcleo & $\Sigma_{f, \text { térmico }}\left(\mathrm{cm}^{-1}\right)$ & $G\left(\frac{J}{\text { fissão }}\right)$ & $q^{\prime \prime \prime}(\vec{r})\left(\frac{W}{\mathrm{~cm}^{3}}\right)$ & $\phi(\vec{r})_{\text {térmico }}\left(\frac{n}{\mathrm{~cm}^{2} \cdot s}\right)$ \\
\hline 8 & 0,159 & $3,204 \mathrm{E}-11$ & 829,20 & $1,63 \mathrm{E}+14$ \\
$8^{*}$ & 0,159 & $3,204 \mathrm{E}-11$ & 846,37 & $1,66 \mathrm{E}+14$ \\
9 & 0,159 & $3,204 \mathrm{E}-11$ & 774,53 & $1,52 \mathrm{E}+14$ \\
10 & 0,159 & $3,204 \mathrm{E}-11$ & 718,52 & $1,41 \mathrm{E}+14$ \\
12 & 0,159 & $3,204 \mathrm{E}-11$ & 634,28 & $1,25 \mathrm{E}+14$ \\
$12^{*}$ & 0,159 & $3,204 \mathrm{E}-11$ & 649,83 & $1,28 \mathrm{E}+14$
\end{tabular}

Comparando com os fluxos térmicos da atual configuração do reator IEA-R1, que variam de $1 \times 10^{13} \mathrm{n} / \mathrm{cm}^{2} . \mathrm{s} \mathrm{a} 4 \times 10^{13} \mathrm{n} / \mathrm{cm}^{2} . \mathrm{s}$, observa-se um aumento significativo.

De forma geral, a análise neutrônica por si só não é suficiente para confirmar o bom funcionamento das novas configurações estudadas, entretanto, fornece parâmetros importantes para que se possa realizar a análise termo-hidráulica, etapa do estudo onde são verificados parâmetros de interesse, como as margens de segurança e os perfis de temperatura ao longo das placas combustíveis.

\section{2 - Análise Termo-Hidráulica}

Antes de se iniciar a análise termo-hidráulica, foi desenvolvida uma breve introdução sobre as mudanças de fases, a dinâmica de formação, crescimento e desprendimento de bolhas em superfícies aquecidas e os regimes de ebulição. Apesar do reator IEA-R1 operar com refrigerante na fase líquida (monofásico), é importante compreender como podem ocorrer as mudanças de fase, para que se possa evitar o aparecimento de um regime bifásico, a existência de bolhas e demais fenômenos que possam prejudicar o funcionamento do atual e também de futuros novos núcleos que o reator IEA-R1 possa vir a possuir.

As margens termo-hidráulicas MDNBR e FIR foram calculadas e seus valores ficaram bem distantes dos limites de projeto (de 1,8 a 2,0). As temperaturas nas placas combustíveis mais quentes de cada nova configuração também não atingiram as temperaturas de ONB e ficaram abaixo da temperatura a partir da qual a probabilidade de corrosão do Alumínio aumenta $\left(\mathrm{T}>95^{\circ} \mathrm{C}\right)$. 
As velocidades de escoamento nos canais de resfriamento se encontram bem abaixo da velocidade crítica $(14,91 \mathrm{~m} / \mathrm{s})$, aquela que provoca instabilidade no escoamento de refrigerante no canal de resfriamento em questão.

Sabendo que a vazão da bomba atual do reator IEA-R1 é de $681,4 \mathrm{~m}^{3} / \mathrm{h}$, a substituição da mesma, a princípio, não seria necessária, sendo que, as vazões apresentadas e utilizadas nos elementos combustíveis do presente trabalho estão dentro daquelas decorrentes da divisão da vazão total atual pelos elementos combustíveis e de controle dos núcleos novos estudados.

\section{3 - Verificação dos Coeficientes de Temperatura e a Queima dos Núcleos}

Os coeficientes de temperatura mostraram-se consistentes em todas as configurações estudadas. As configurações 5, 6 e 7 mostraram-se incapazes, do ponto de vista de queima, pois possuem baixo excesso de reatividade, fazendo com que os núcleos sejam desligados com o passar de 2h24min após serem ligados.

Isso se deve principalmente pelo efeito do Xe-135 que, como visto, adiciona cerca de 4000 pcm's de reatividade negativa no início da operação dos reatores (Fig. 60, 61, 62 e $63)$.

Os combustíveis, em média, são pouco queimados até que seja necessário realizar o gerenciamento do núcleo devido ao fim do excesso de reatividade. $\mathrm{O}$ desligamento dos núcleos ocorrem dentro dos seguintes períodos de tempo:

- Núcleos 8 e 8*: Entre 60 e 100 dias de operação;

- Núcleos 9 e 10: Entre 100 e 150 dias de operação;

Estudos específicos, monitorando a queima de cada placa combustível serão necessários caso a mudança do núcleo atual para configurações menores de fato seja realizada no futuro, para se definir a metodologia de gerenciamento do núcleo, que envolve a troca 
de elementos combustíveis de posição, assim como a retirada daqueles onde a queima já tenha atingido os valores máximos permitidos.

\section{4 - Simulação de um APR}

A simulação de um APR, referente à análise de segurança, mostrou que, dos acidentes postulados para o reator IEA-R1, a ruptura da fronteira do primário é o evento mais crítico. Isso se deve ao fato desse evento possuir o menor tempo para esvaziamento completo da piscina (nível de água abaixo da parte ativa do núcleo), cerca de 350s (Fig. $68)$.

Esse evento motiva a verificação das temperaturas máximas atingidas no elemento combustível mais quente dos novos núcleos propostos para o reator IEA-R1. Para tal, admitiu-se um tempo de operação de 120 horas semanais e também, para efeitos de comparação, de 233 dias contínuos (potência de 5MW).

Um estudo paramétrico foi realizado para os novos núcleos, uma vez que, perdendo-se toda a água da piscina, em 350s (caso mais crítico), rapidamente a temperatura no combustível ultrapassa $500^{\circ} \mathrm{C}$ (Fig. $74,77,80$ e 83), valor esse referente a temperatura de empolamento $\left(475^{\circ} \mathrm{C}\right.$ a $550^{\circ} \mathrm{C}$ para combustíveis tipo dispersão) das placas combustíveis (limite térmico). Para além da temperatura de empolamento, ocorre o inchamento da placa devido à expansão dos gases ou produtos de fissão nela contidos, com a consequente obstrução do canal de resfriamento e posterior elevação da temperatura da placa até sua fusão. $\mathrm{Na}$ verdade, a temperatura de empolamento varia entre $350^{\circ} \mathrm{C}$ a $600^{\circ} \mathrm{C}$, principalmente em função do tipo de combustível utilizado, do grau de enriquecimento e da porcentagem de queima.

Os tempos necessários para que nos núcleos $8,8^{*}, 9$ e 10 atinjam a temperatura de $500^{\circ} \mathrm{C}$ são, respectivamente, 8,05 minutos, 9,72 minutos, 9,13 minutos e 8,52 minutos. Assim, é necessário determinar o tempo de esvaziamento (seguro) para que as temperaturas máximas após o esvaziamento completo da piscina não atinjam a temperatura que promove empolamento nas placas. 
Lembrando também que a temperatura de fusão do Alumínio, revestimento do combustível nuclear, é $660^{\circ} \mathrm{C}$. O atual núcleo do reator IEA-R1 necessita de um tempo de 10,7h para descobrimento seguro do núcleo caso operasse 233 dias contínuos e 1,5h numa operação semanal de 120h/semana (Fig. 85 e 86).

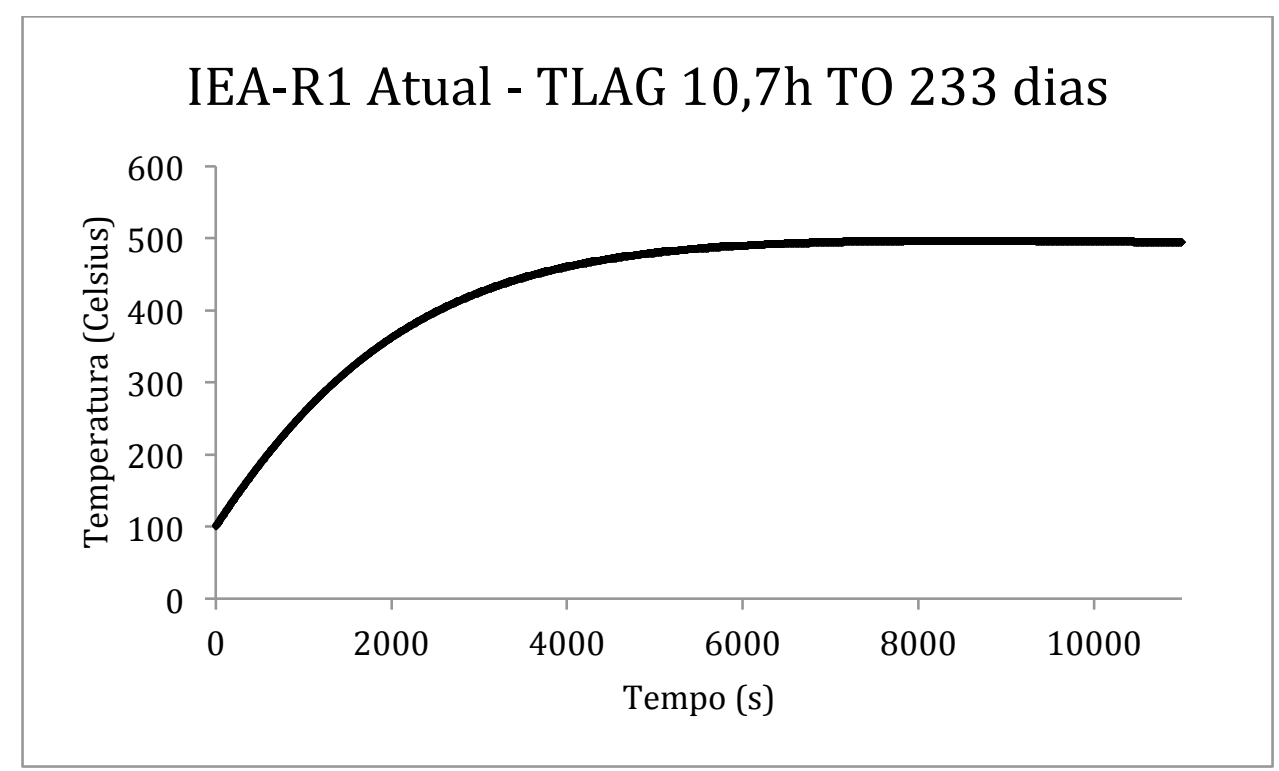

Figura 84 - Temperaturas atingidas após o descobrimento total do núcleo atual do reator IEA-R1, operando 233 dias contínuos. Tempo de esvaziamento seguro igual a 10,7h.

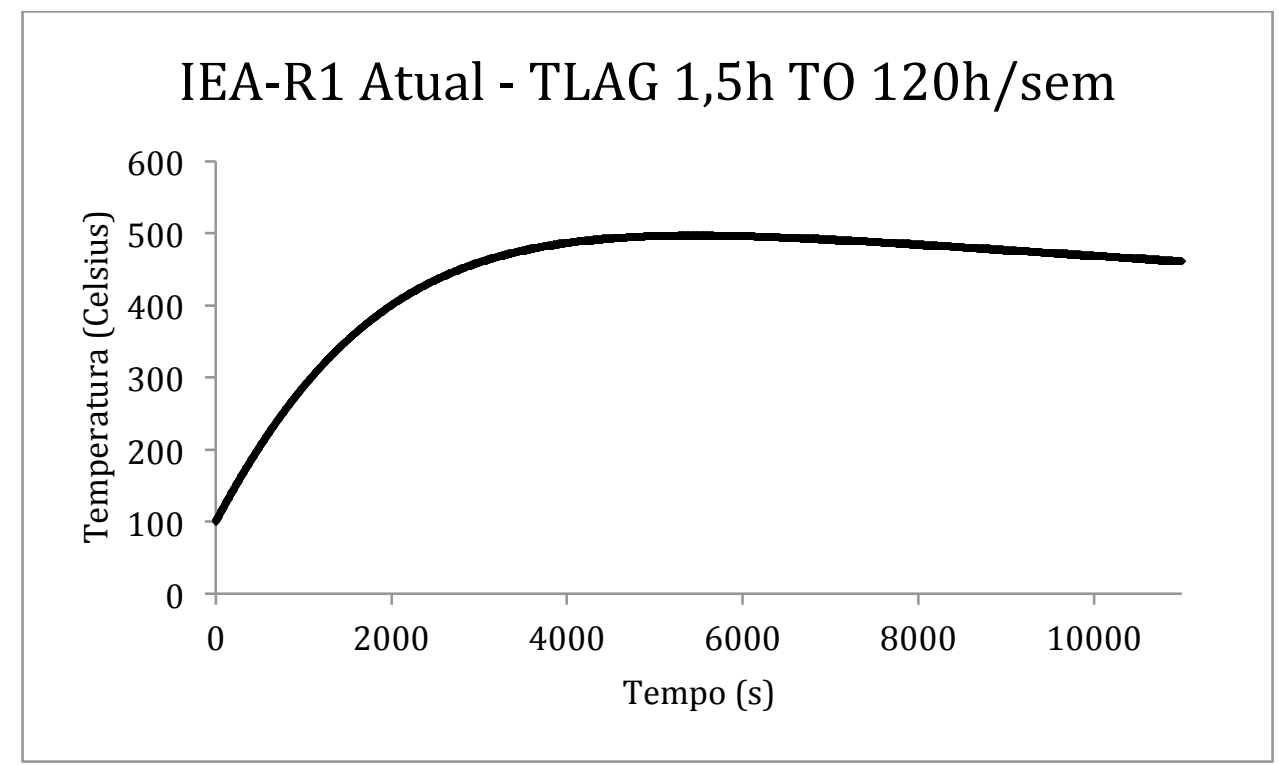

Figura 85 - Temperaturas atingidas após o descobrimento total do núcleo atual do reator IEA-R1, operando $120 \mathrm{~h}$ semanais. Tempo de esvaziamento seguro igual a $1,5 \mathrm{~h}$. 
Comparando com os resultados das Figuras 74 a 84, observa-se que a estrutura atual do reator IEA-R1 é compatível com os tempos de esvaziamento seguro para os novos núcleos, num regime de operação de $120 \mathrm{~h}$ semanais. O atual sistema consegue evitar o esvaziamento do núcleo em até 10,7h.

Apesar dos núcleos 12 e 12* terem sido excluídos de parte das análises, a fim de se focar as atenções em núcleos mais compactos, nada impede, a princípio, que esses núcleos possam vir a ser utilizados como novos núcleos para o reator IEA-R1, bastando a verificação de todos os parâmetros necessários para tal. 


\section{Conclusões}

Com o fim do presente trabalho, conclui-se que novas configurações mais compactas para o reator IEA-R1, operando a $5 \mathrm{MW}$ e utilizando combustível $\mathrm{U}_{3} \mathrm{Si}_{2}-\mathrm{Al}$ com $4,8 \mathrm{gU} / \mathrm{cm}^{3}$, são possíveis.

Os cálculos neutrônicos e termo-hidráulicos mostraram que as configurações $5,6,7,8$, $8^{*}, 9,10,12$ e $12^{*}$ possuem os requisitos e margens de segurança necessários para um bom funcionamento dos núcleos, sem violar limites térmicos ou ultrapassar valores de fatores limitantes de projeto. Com o aumento dos fluxos térmicos, novas possibilidades de pesquisas e aplicações serão possíveis, como por exemplo as pesquisas relacionadas à produção de radioisótopos, largamente utilizados para fins medicinais e tratamento de pacientes.

Após a queima, constatou-se que os núcleos supercompactos, como os 5, 6 e 7, não possuem excesso de reatividade necessário para manter o núcleo ligado, sendo impossível trabalhar com essas configurações nas condições anteriormente mencionadas.

A simulação de um APR para as demais configurações $\left(8,8^{*}, 9\right.$ e 10$)$, aponta que a temperatura de empolamento $\left(\sim 500^{\circ} \mathrm{C}\right)$ não é atingida se os tempos seguros para o esvaziamento da piscina do reator forem obedecidos, tempos estes compatíveis com o sistema atual do reator IEA-R1, com os novos núcleos operando num regime de 120h/semana.

Por fim, encerra-se este estudo confirmando que a ideia de redução do núcleo atual do IEA-R1, da mesma forma como já ocorreu um dia, é factível e poderá trazer uma série de benefícios futuramente, inclusive permitir que o reator em questão possa continuar operando e atendendo as necessidades do IPEN/CNEN-SP e também de toda a sociedade. 


\section{Sugestões para Trabalhos Futuros}

A conclusão desse estudo abre uma série de novas possibilidades para trabalhos futuros referentes à redução do núcleo do reator IEA-R1. Vários estudos podem ser feitos particularizando e especificando o uso de tais novas configurações.

Uma vez conhecida a finalidade principal que o novo núcleo terá, pode-se aprofundar as análises neutrônica e termo-hidráulica para que se possa avaliar diversos parâmetros ao longo do núcleo, tais como o mapeamento dos fluxos térmico e rápido em diversas posições e a escolha das melhores posições para irradiação, seja para uso em pesquisa básica, seja para produção de radioisótopos ou outras aplicações, como sugere o aumento nos fluxos térmicos dos novos núcleos. Assim, mesmo após o fim deste estudo, as possibilidades de trabalhos são extensas.

Um estudo sistemático e objetivo junto à comunidade científica do IPEN/CNEN-SP deve ser desenvolvido, a fim de decidir qual rumo o reator IEA-R1 deve tomar nos próximos anos. Isso é importante para definir qual seria a configuração mais adequada para esse reator e, por fim, possibilitar estudos mais aprofundados, conforme mencionado anteriormente. 


\section{REFERÊNCIAS BIBLIOGRÁFICAS}

1- SILVA, A. T.; TERREMOTO, L. A. A.; SILVA, J. E. R.; ALMEIDA, Cirila Tacconi de; DAMY, M. A.; UMBEHAUN, P. E.; YAMAGUCHI, M. . Qualification program of research reactor fuels manufactured at IPEN CNEN/SP. Progress in Nuclear Energy, v. 50, p. 795-799, 2008.

2- DOMINGOS, D. B. Cálculos Neutrônicos, Termo-hidráulicos e de Segurança de um Dispositivo para Irradiação de Miniplacas (DIM) de Elementos Combustíveis Tipo Dispersão, 2010, Dissertação de Mestrado em Tecnologia Nuclear- São Paulo (IPEN), 2010.

3- NICK HAUSER, Overview of the OPAL research reactor (ANSTRO), March 2011.

4- RONALD A. CRONE, CHRIS BRYAN, High Flux Isotope Reactor operation and capabilities, June 2013, Presentation.

5- Silva, J. E. R. ; SilvA, A. T. ; DOMIngOS, D. B. ; TERREMOTO, L. A. A. Application of Nondestructive Methods for Qualification of High Density Fuels in the IEA- R1 Reactor. In: RRFM 2011, Rome - Italy. RRFM 2011 Transactions. Brussels Belgium : European Nuclear Society, 2011. v. 1. p. 1-5.

6- DOMInGOS, D. B.; SILVA, A. T.; SILVA, J. E. R. Qualification Process of Dispersion Fuels in the IEAR1 Research Reactor. In: RRFM 2010, 2010, Marrakech, Morroco. RRFM 2010 Transactions. Bruxelas : European Nuclear Society ENS, 2010. v. 1. p. 1-5.

7- DOMINGOS, D. B.; SILVA, A. T.; UMBEHAUN, P. E.; SILVA, J. E. R.; CONTI, T. N.; YAMAGUCHI, M. Neutronic, Thermal-Hydraulic and Accident Analysis Calculations for an Irradiated Device to be Used in the Qualification Process of Dispersion Fuels in the IEA-R1 Research Reactor. In: International Nuclear Atlantic Conference - INAC 2009, Rio de Janeiro. INAC 2009. Rio de Janeiro : Associação Brasileira de Energia Nuclear, 2009. v. 1. p. 1-9. 
8- SILVA, J. E. R., Aplicação de Métodos Não Destrutivos para Qualificação de Combustíveis Tipo Dispersão de $\mathrm{U}_{3} \mathrm{O}_{8}-\mathrm{Al}$ e $\mathrm{U}_{3} \mathrm{Si}_{2}-\mathrm{Al}$ no Reator IEA-R1, 2011, Tese de Doutorado em Tecnologia Nuclear- São Paulo (IPEN), 2011.

9- TORRES, W. M.; UMBEHAUN, P. E.; ANDRADE, D. A., Experimento para o dimensionamento da placa de limitação de vazão (PLV) do dispositivo de irradiação de miniplacas (DIM) do IEA-R1. Relatório Técnico P\&D.CENT.CENT.035.00RELT.01.R00. Dezembro de 2002.

10- FOWLER, T. B. , VONDY, D. R., CUNNINGHAN, G. W., "Nuclear Reactor Core Analysis Code: CITATION", Oak Ridge National Laboratory, ORNL-TM-2496, Rev. 2, Suppl. 3, July 1972.

11- BARHEIN, J.; RHOTENSTEIN, W. and TAVIV, E. , "The HAMMER Code System TECHNION”, Institute of Technology, Haifa, Israel, NP-565, 1978.

12- P. SCHREINER and W. KRULL, The New Compact Core Design of the FRG-1 GKSS - Forschungszentrum Geesthacht GmbH - Max-Planck-Strabe, D-21502 Geesthacht, Germany (IAEA-SM-360/43).

13- K. BONING and P. VON DER HARDT, "Physics and Safety of Advanced Research Reactors," Nuclear Instruments and Methods in Physics Research A260 p.239-246 (1987) .

14- ZEYUN WU, MAX CARLSON et al. A Novel Compact Core Design for Beam Tube Research Reactors. Transactions of the American Nuclear Society, Vol. 112, San Antonio, Texas, June 7-11, 2015.

15- MCNP - A General Monte Carlo N-Particle Transport Code, Version 5, Los Alamos National Laboratory, April 242003 (Revised 10/3/05).

16- SERPENT, Leppänen, Jaakko. "User Manual" (PDF). Retrieved 6 March 2013.

17- INTERNATIONAL ATOMIC ENERGY AGENCY (IAEA). Safety Assessment of Research Reactors and Preparation of the Safety Analysis Report, No 35 - G1, Viena (1994). 
18- SIMÕES, A. V., Reações Químicas Matriz-Partícula em Combustíveis $U_{3} O_{8}$ Al de MTR, IPEN/COPESP, Documento n. R452070003452/01, Março 1988.

19- PERROTTA, J. A.. Resumo de Notas de Aula do Curso de Projeto do Combustivel Tipo Placa, CNEA, Argentina 1985.

20- KLEIN, S.A.; ALVARADO F.L. EES Engineering equation solver for the microsoft windows operating system. Version 4.334W Dec. 1996. Middleton, WI. :F-Chart Software, 1992.

21- UMBEHAUN, P.E. Metodologia para análise Termo-Hidráulica de Reatores de Pesquisa tipo Piscina com Combustível tipo Placa. 2000. Dissertação (Mestrado) - Instituto de Pesquisas Energéticas e Nucleares, São Paulo.

22- JASON CHAO: COBRA-3C/RERTR - A Thermal-Hydraulic Sub-channel Code with Low Pressure Capabilities Science Applications, Inc. (December 25, 1980).

23- C. F. OBENCHAIN, "PARET - A Program for the Analysis of Reactor Transients," IDO-17282 (January 1969).

24- NJOY 2012 User Manual LA-UR-12-27079;

25- GOLDEN, G. H., Elementary Neutronics Considerations in LMFBR Designe, ANL Report No. 7532 (March 1969).

26- LABUNTSOV, D. A. Critical thermal loads in forced motion of water, which is heated to a temperature below the saturation temperature. Soviet Journal of Atomic Energy, v. 10, n' 5, p. 523-525,1960.

27- MIRSHAK, S. ; DURANT, W.D.; TOWELL, R.H. Heat transfer flux at burnout [S.1.]: DuPont, Feb. 1959.(DP355).

28- EL -WAKIL , M. M. Nuclear Heat Transport, American Nuclear Society, 1978. 
29- TIPTON, C. R., Jr. (ed.) Reactor Handbook, Vol. 1, Materials 2d ed. Prepared under contract with U.S. Atomic Energy Commission Inc., New York; Interscience, 1960.

30- MILLER, D.R. Critical velocities for collapse of reactor parallel plate fuel assemblies.[S.1.:s.n.], Aug. 1958. (KAPL-1954).

31- EL -WAKIL, M. M. Nuclear Power Engineering, New York: McGraw-Hill, 1962.

32- LAMARSH, J. R. Introduction to Nuclear Reactor Theory, American Nuclear Society, 2002.

33- CASE, K. M, F. de HOFFMANN, and G. PLACZEK, Introduction to the Theory of Neutron Diffusion, vol. I, U.S. AEC Report, 1953.

34- INTERNATIONAL ATOMIC ENERGY AGENCY. Research Reactor Core Conversion Guidebook. Vienna, Apr. 1992. (IAEA-TECDOC-643).

35- INTERNATIONAL ATOMIC ENERGY AGENCY. Code on The Safety of Nuclear Research Reactors: Design. Vienna, 1992. (IAEA - Safety Standards No 35$\mathrm{S} 1)$.

36- WHITE, FRANK M. (2003). Fluid Mechanics. McGraw-Hill. ISBN 0-07-2402172.

37- CRANE. Flow of Fluids Through Valves, Fittings and Pipe Metric Edition - SI Units. New York, N. Y., 1977, p. A26-A29.

38- IDELCIK, I. E. Memento des Pertes de Charge. Paris: Eyrolles, 1969. P. 103.

39- IPEN-CNEN/SP - COPESP/SP. Memorial de Cálculo do Circuito Primário do Reator IEA-R1. São Paulo. Jan. 1988. (Documento Interno R19-IP4-214PR-4MS-001). 
40- MAPRELIAN, E. Análise de acidentes de perda de refrigerante no reator IEA-R1 a 5 MW. 1998. Dissertação (Mestrado) - Instituto de Pesquisas Energéticas e Nucleares, São Paulo.

41- LOS ALAMOS SCIENTIFIC LABORATORY. 1969 STATUS REPORT on the Omega West Reactor, with Safety Analysis. Los Alamos, Cal., May 1969. (LA-4192, TID-4500).

42- PERROTA, J. A., Curso de Introdução à Engenharia de Reatores - Julho, 1999 (Apostila). 


\title{
APÊNDICE A
}

\section{Input MCNP: Núcleo 8}

\author{
C NUCLEO+ARREDORES+EXTERIOR

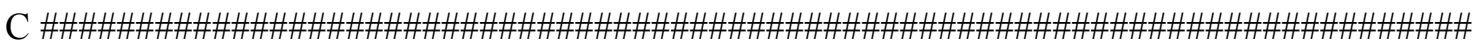 \\ $\mathrm{C}$ \\ $100-1 \quad \# 6001$ \#6002 \#6003 \#6004 \#6005 \#6006 \#6007 \#6008
}

FILL=1 IMP:N=1 \$ NUCLEO

$21-1.0-2 \quad$ IMP:N=1 \$ X+

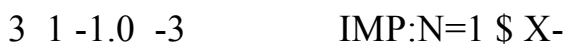

$4-1.0-4 \quad$ IMP:N=1 \$ Y+

$51-1.0-5 \quad$ IMP:N=1 \$ Y-

6 1 - 1.0 -6 \#6001 \#6002 \#6003 \#6004 \#6005 \#6006 \#6007 \#6008 IMP:N=1 \$ Z+

$7 \quad 1-1.0-7 \quad$ IMP:N=1 \$ Z-

$801234567 \quad$ IMP:N=0 \$ EXTERIOR DESPREZADO

$\mathrm{C}$

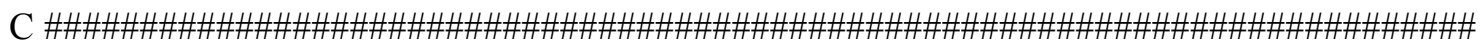

C MALHA DO NUCLEO (UNIVERSO U=1)

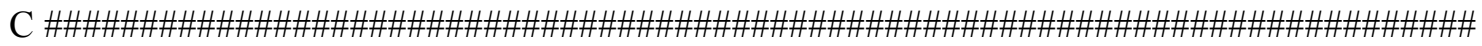

$\mathrm{C}$

$10 \quad 1-1.0 \quad-16 \quad$ LAT=1 FILL= $-4: 3 \quad-3: 6 \quad 0: 0$

$\mathrm{C}$

C COLUNAS $>>1 \quad \begin{array}{llllllllll}1 & 2 & 3 & 4 & 5 & 6 & 7 & 8 & \text { LINHAS }\end{array}$

$\begin{array}{lllllllll}20 & 20 & 20 & 20 & 30 & 20 & 20 & 20 & \$ 9\end{array}$

$\begin{array}{lllllllll}20 & 20 & 30 & 30 & 101 & 30 & 30 & 20 & \$ 8\end{array}$ 
$2020301211011217020 \quad \$ 7 \$$

$20201011019010110120 \$ 6 \$$

$2020601211011217020 \quad \$ 5 \$$

$\begin{array}{lllllllll}20 & 20 & 30 & 30 & 101 & 30 & 30 & 20 & \$ 4\end{array}$

$\begin{array}{lllllllll}20 & 20 & 20 & 20 & 30 & 20 & 20 & 20 & \text { \$ } 3 \text { \$ }\end{array}$

$2020202020202020 \quad \$ 2 \$$

$2020202020202020 \quad$ \$ 1 \$

$2020202020202020 \quad \$ 0 \$$

C COLUNAS $>>\quad \begin{array}{llllllll}1 & 2 & 3 & 4 & 5 & 6 & 7 & 8\end{array}$

C

$\mathrm{U}=1 \quad \mathrm{IMP}: \mathrm{N}=1$

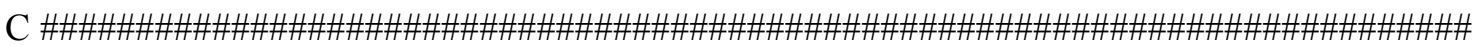

C ELEMENTOS NAO COMBUSTIVEL

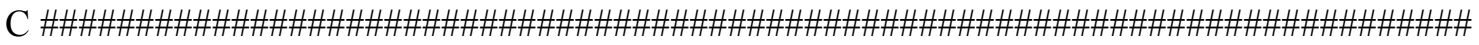

C MALHA DO ELEMENTO REFLETOR DE GRAFITE (UNIVERSO U=20)

C PARTE 1 (SUPERIOR)

$201-1.0 \quad 63 \quad$ U=20 IMP:N=1 \$ AGUA PARTE DE CIMA

C PARTE 2

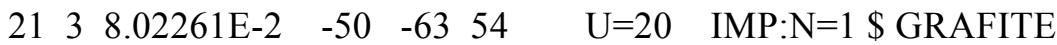

$2226.02442 \mathrm{E}-2 \quad 50 \quad-51-63 \quad 54 \quad \mathrm{U}=20 \quad$ IMP:N=1 \$ REVEST. DE AL

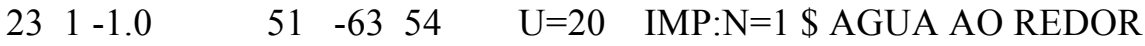

C PARTE 3

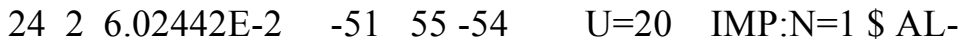

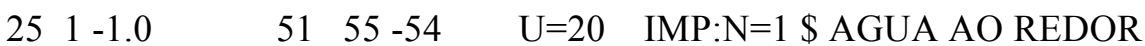

C PARTE 4 (INFERIOR)

$260 \quad-55 \quad$ FILL=21 U=20 IMP:N=1 \$ GRADE INFERIOR

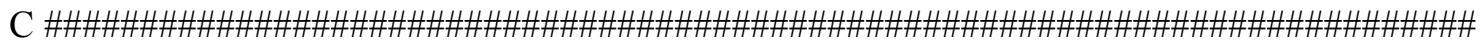

C MALHA DO ELEMENTO REFLETOR DE BERILIO (Metalico)(UNIVERSO 30) 
C PARTE 1 (SUPERIOR)

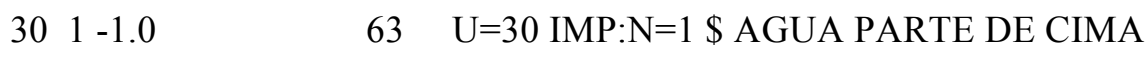

C PARTE 2

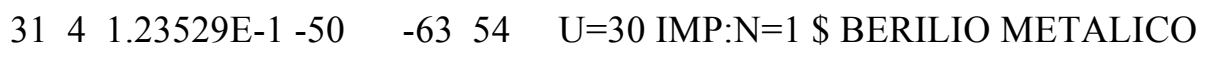

$3226.02442 \mathrm{E}-2 \quad 50-51 \quad-6354 \quad \mathrm{U}=30$ IMP:N=1 \$ REVEST AL

$33 \quad 1-1.0 \quad 51-6354 \quad$ U=30 IMP:N=1 \$ AGUA AOS LADOS

C PARTE 3

$3426.02442 \mathrm{E}-2 \quad-51 \quad 55-54 \quad \mathrm{U}=30 \mathrm{IMP}: \mathrm{N}=1 \$ \mathrm{AL}-$

$35 \quad 1-1.0 \quad 51 \quad 55-54 \quad$ U=30 IMP:N=1 \$ AGUA AOS LADOS

C PARTE 4 (INFERIOR)

$360 \quad-55 \quad$ FILL=21 U=30 IMP:N=1 \$ GRADE-

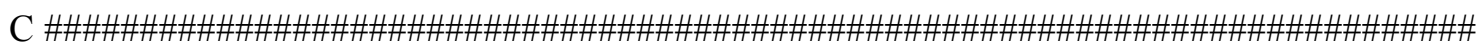

C MALHA DAS PARTES SEM ELEMENTOS (AGUA+PLACA MATRIZ C/Tampao)(U=40)

C PARTE 1 (AGUA SUPERIOR)

$401-1.055 \quad \mathrm{U}=40$ IMP:N=1 \$ AGUA+

C PARTE 2 (INFERIOR, PLACA MATRIZ COM TAMPAO)

$410 \quad-55$ FILL=22 U=40 IMP:N=1 \$ GRADE

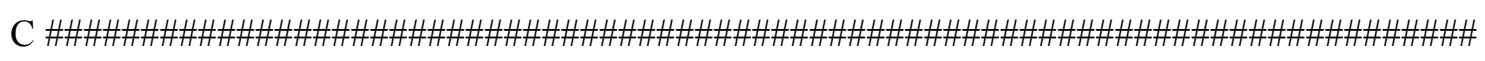

C MALHA DO ELEMENTO DE IRRADIACAO (EIRA)(UNIVERSO 50)

C PARTE 1 (SUPERIOR)

$50 \quad 1-1.0 \quad 63 \quad$ U=50 IMP:N=1 \$ AGUA ACIMA

C PARTE 2

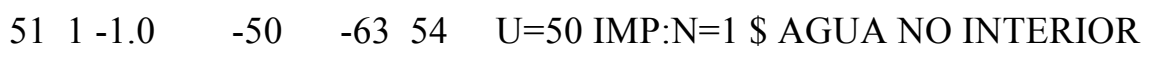

$5226.02442 \mathrm{E}-2 \quad 50-51 \quad-6354 \quad$ U=50 IMP:N=1 \$ REVEST AL

$53 \quad 1-1.0 \quad 51-63 \quad 54 \quad$ U=50 IMP:N=1 \$ AGUA AO REDOR

C PARTE 3

$5426.02442 \mathrm{E}-2 \quad-51 \quad 55-54 \quad \mathrm{U}=50$ IMP:N=1 \$ AL- 
$55 \quad 1-1.0$

$5155-54 \quad$ U=50 IMP:N=1 \$ AGUA AO REDOR

C PARTE 4 (INFERIOR)

$560 \quad-55 \quad$ FILL=21 U=50 IMP:N=1 \$ GRADE ABAIXO

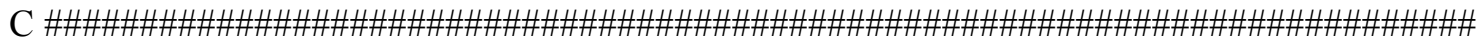

C MALHA DO ELEMENTO DE IRRADIACAO (EIBRA-1 ESQUERDA NO PLANO $\mathrm{XY})(\mathrm{U}=60)$

C PARTE 1 (SUPERIOR)

$601-1.0 \quad 63 \quad$ U=60 IMP:N=1 \$ AGUA ACIMA

C PARTE 2

$61 \quad 4 \quad 1.23529 \mathrm{E}-1-52 \quad-6354 \quad \mathrm{U}=60$ IMP:N=1 \$ BERILIO METALICO

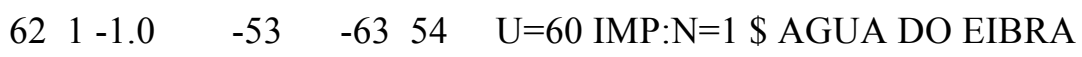

$6326.02442 \mathrm{E}-2 \quad 50-51 \quad-6354 \quad$ U=60 IMP:N=1 \$ REVEST Al

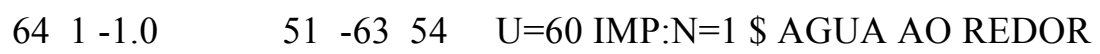

C PARTE 3

$6526.02442 \mathrm{E}-2 \quad-51 \quad 55-54 \quad \mathrm{U}=60$ IMP:N=1 \$ AL-

$66 \quad 1-1.0 \quad 51 \quad 55-54 \quad$ U=60 IMP:N=1 \$ AGUA AO REDOR

C PARTE 4 (INFERIOR)

$670 \quad-55 \quad$ FILL=21 U=60 IMP:N=1 \$ GRADE-

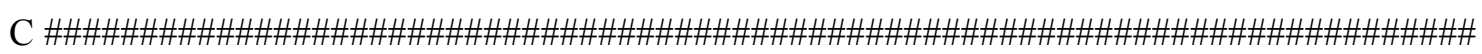

C MALHA DO ELEMENTO DE IRRADIACAO (EIBRA-2 DIREITA XY)(UNIVERSO 70)

C PARTE 1 (SUPERIOR)

$70 \quad 1-1.0 \quad 63 \quad$ U=70 IMP:N=1 \$ AGUA ACIMA

C PARTE 2

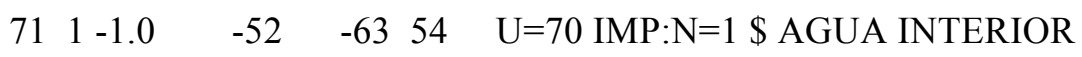

$724 \quad 1.23529 \mathrm{E}-1-53 \quad-6354 \quad \mathrm{U}=70$ IMP:N=1 \$ BERILIO METALICO

$7326.02442 \mathrm{E}-2 \quad 50-51 \quad-6354 \quad \mathrm{U}=70$ IMP:N=1 \$ REVEST AL

$74 \quad 1-1.0 \quad 51-6354 \quad$ U=70 IMP:N=1 \$ AGUA AO REDOR

C PARTE 3 
$7526.02442 \mathrm{E}-2 \quad-51 \quad 55-54 \quad \mathrm{U}=70$ IMP:N=1 \$ AL-

$76 \quad 1-1.0 \quad 51 \quad 55-54 \quad$ U=70 IMP:N=1 \$ AGUA AO REDOR

C PARTE 4 (INFERIOR)

$770 \quad-55 \quad$ FILL=21 U=70 IMP:N=1 \$ GRADE-

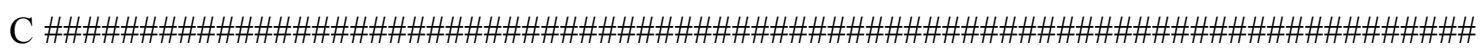

C MALHA DO ELEMENTO DE IRRADIACAO CENTRAL (EIBE)(UNIVERSO 90)

C PARTE 1 (SUPERIOR)

$90 \quad 1-1.0 \quad 63 \quad$ U=90 IMP:N=1 \$ AGUA ACIMA

C PARTE 2

914 1.13529E-1 -50 $6061 \quad-63 \quad 54$ U=90 IMP:N=1 \$ BERILIO

$92 \quad 1-1.0 \quad-60 \quad-63 \quad 54$ U=90 IMP:N=1 \$ CANAL AGUA 1

$93 \quad 1-1.0 \quad-61 \quad-63 \quad 54$ U=90 IMP:N=1 \$ CANAL AGUA 2

$9426.02442 \mathrm{E}-2 \quad 50 \quad-51 \quad-63 \quad 54$ U=90 IMP:N=1 \$ REVEST Al

$95 \quad 1-1.0 \quad 51 \quad-63 \quad 54$ U=90 IMP:N=1 \$ AGUA AO REDOR

C PARTE 3

$9626.02442 \mathrm{E}-2 \quad-496061 \quad 55-54$ U=90 IMP:N=1 \$ AL/Base

$97 \quad 1-1.0 \quad-60 \quad 55-54$ U=90 IMP:N=1 \$ CANAL/AGUA1/Base

$981-1.0 \quad-61 \quad 55-54$ U=90 IMP:N=1 \$ CANAL AGUA2/Base

$991-1.0 \quad 49 \quad 55-54$ U=90 IMP:N=1 \$ AGUA AO REDOR

C PARTE 4 (INFERIOR)

$1000 \quad-55$ FILL=21 U=90 IMP:N=1 \$ GRADE-

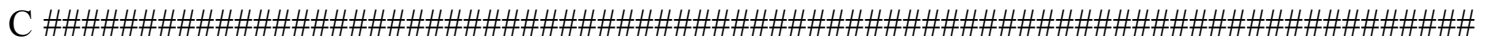

C BOCAL INTERNO A PLACA MATRIZ (UNIVERSO U=21)

C

$110 \quad 1-1.0 \quad-58 \quad$ U=21 IMP:N=1 \$ CANAL AGUA

$11126.02442 \mathrm{E}-258 \quad \mathrm{U}=21 \mathrm{IMP}: \mathrm{N}=1$ \$ AL EXT

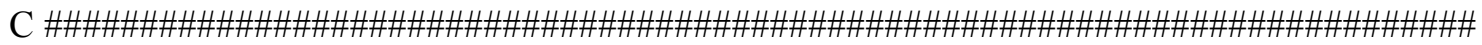

C BOCAL INTERNO A PLACA MATRIZ (UNIVERSO U=22) (P/TAMPAO) 
$\mathrm{C}$

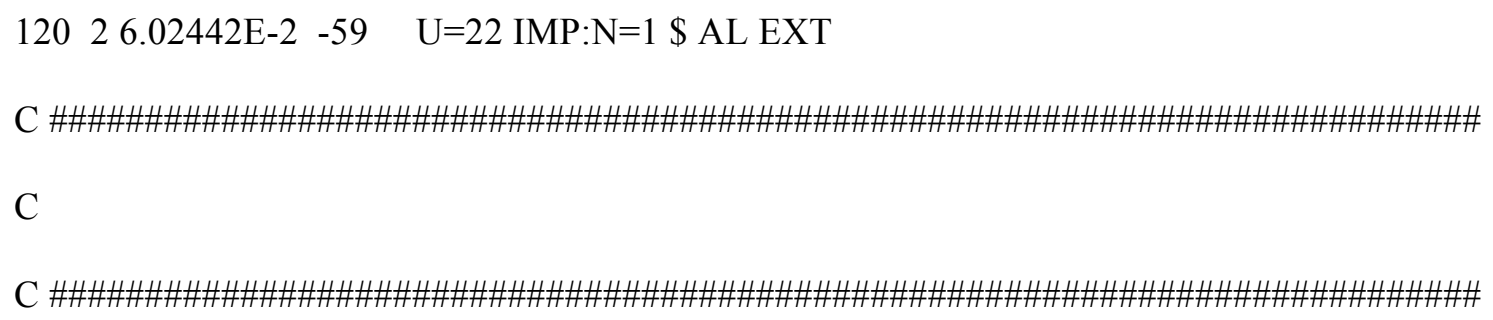


$10151-1.0717273 \quad 54-64 \quad$ U=101 IMP:N=1 \$ AGUA

C PARTE 5

$101626.02442 \mathrm{E}-2 \quad-71 \quad 55-54 \quad \mathrm{U}=101 \mathrm{IMP}: \mathrm{N}=1$ \$ AL ESQ

$1017 \quad 1-1.0 \quad-72 \quad 55-54 \quad$ U=101 IMP:N=1 \$ AGUA INTERNA

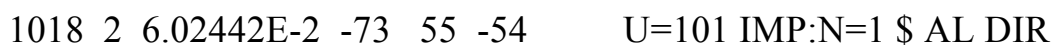

$10191-1.0717273 \quad 55-54 \quad$ U=101 IMP:N=1 \$ AGUA

C PARTE 6 (INFERIOR)

$10200 \quad-55 \quad$ FILL=21 U=101 IMP:N=1 \$ GRADE-

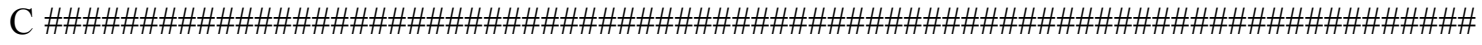

C ELEMENTO COMBUSTIVEL DE CONTROLE 121 (APARECE 4 VEZES NO NUCLEO)

C PARTE 1 (SUPERIOR)

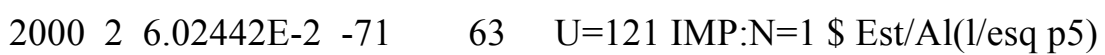

$2001 \quad 1-1.0 \quad-72 \quad 63 \quad$ U=121 IMP:N=1 \$ H2O

$200226.02442 \mathrm{E}-2-73 \quad 63 \quad$ U=121 IMP:N=1 \$ Est/Al(1/dir p5)

$2003 \quad 1-1.0717273 \quad 63 \quad$ U=121 IMP:N=1 \$ H2O

C PARTE 2

$200426.02442 \mathrm{E}-2 \quad-71 \quad 62-63 \quad$ U=121 IMP:N=1 \$ Est/Al(1/esq)

$2005 \quad 0 \quad-72 \quad 62-63$ FILL=500 U=121 IMP:N=1 \$ Pl/Al s/Comb(p/sup)

$200626.02442 \mathrm{E}-2 \quad-73 \quad 62 \quad-63 \quad$ U=121 IMP:N=1 \$ Est/Al(1/dir)

$2007 \quad 1-1.0717273 \quad 62-63 \quad$ U=121 IMP:N=1 \$ H2O

C PARTE 3

$200826.02442 \mathrm{E}-2 \quad-71 \quad 64-62 \quad \mathrm{U}=121$ IMP:N=1 \$ Est/Al(1/esq)

$2009 \quad 0-72 \quad 64 \quad-62 \quad$ FILL=501 U=121 IMP:N=1 \$ Pl/Al c/Comb(p/atv)

$201026.02442 \mathrm{E}-2 \quad-73 \quad 64 \quad-62 \quad$ U=121 IMP:N=1 \$ Est/Al(1/dir)

$2011 \quad 1-1.0717273 \quad 64-62 \quad$ U=121 IMP:N=1 \$ H2O p3

C PARTE 4

$201226.02442 \mathrm{E}-2 \quad-71 \quad 54 \quad-64 \quad \mathrm{U}=121$ IMP:N=1 \$ Est/Al(1/esq)

$20130-7254 \quad-64$ FILL=500 U=121 IMP:N=1 \$ Pl/Al s/Comb(p/inf) 
$201426.02442 \mathrm{E}-2 \quad-7354 \quad-64 \quad \mathrm{U}=121$ IMP:N=1 \$ Est/Al(1/dir)

$2015 \quad 1-1.0717273 \quad 54-64 \quad$ U=121 IMP:N=1 \$ H2O

C PARTE 5

$201626.02442 \mathrm{E}-2 \quad-71 \quad 55 \quad-54 \quad \mathrm{U}=121$ IMP:N=1 \$ Est/Al(1/esq)

$2017 \quad 1-1.0 \quad-72 \quad 55-54 \quad \mathrm{U}=121$ IMP:N=1 \$ H2O

$201826.02442 \mathrm{E}-2 \quad-73 \quad 55 \quad-54 \quad$ U=121 IMP:N=1 \$ Est/Al(1/dir)

$2019 \quad 1-1.0717273 \quad 55 \quad-54 \quad$ U=121 IMP:N=1 \$ H2O

C PARTE 6 (INFERIOR)

$20200 \quad-55$ FILL=21 U=121 IMP:N=1 \$ GRADE-

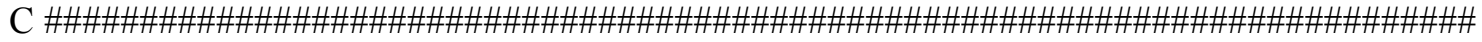

C REGIAO EM Z DE AGUA +Pl DE Al DOS ECP E ECC

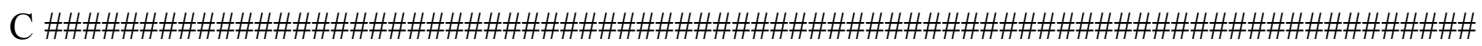

C U=200 - H2O e PL Al(Malha/ECP) para o U=101 a 124

C

$3000 \quad 0-81 \quad$ LAT $=1 \quad$ FILL=0:0 -10:9 0:0 300 19R U=200 IMP:N=1

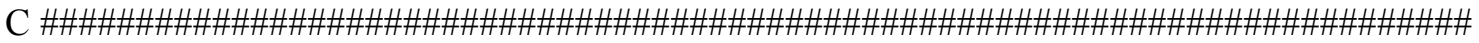

C REGIAO EM Z DE AGUA +Pl com Comb dos ECP

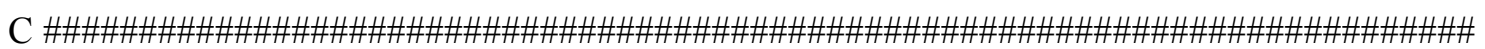

C U=201 - H2O e PL Al con Comb (Malha/ECP) para o U=101

$\mathrm{C}$

3010 0 -81 LAT=1 FILL=0:0 -10:9 0:0 301 301 301 15R

$301301 \mathrm{U}=201 \mathrm{IMP}: \mathrm{N}=1$

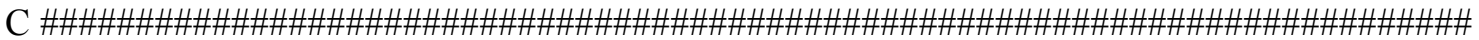

C Regiao em z de $\mathrm{H} 2 \mathrm{O}+\mathrm{Pl}$ de $\mathrm{Al}$ dos ECC

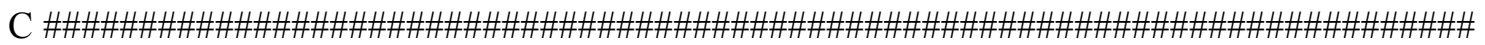

C U=500 - H2O e PL Al(Malha/ECC) para o U=121

C 
$32101-1.0-81 \quad$ LAT=1 FILL=0:0 -10:9 0:0 500300500300300 11R

$300500300500 \mathrm{U}=500 \mathrm{IMP}: \mathrm{N}=1$

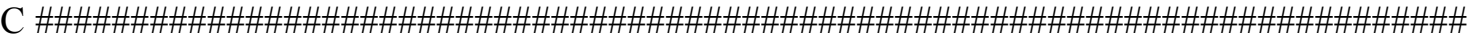

C Regiao em z de $\mathrm{H} 2 \mathrm{O}+\mathrm{Pl}$ de $\mathrm{Al}$ com Comb dos ECC

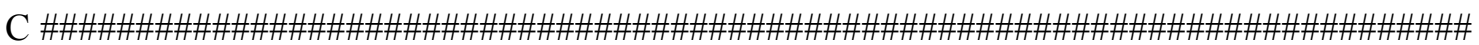

$\mathrm{C} \mathrm{U}=501-\mathrm{H} 2 \mathrm{O}$ e PL Al con Comb(Malha/ECC) para o $\mathrm{U}=121$

$\mathrm{C}$

$32201-1.0-81 \quad$ LAT=1 FILL=0:0 -10:9 0:0 $50130050130030111 \mathrm{R}$

$300501300501 \mathrm{U}=501 \mathrm{IMP}: \mathrm{N}=1$

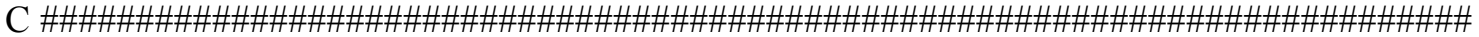

C Barras de Controle

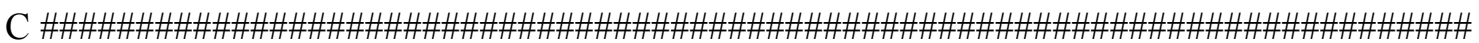

C Placas Absorvedoras

$\mathrm{C}$

600110 5.613504E-02 -91 65 -66 IMP:N=1 \$ P1 de Ag-In-Cd n.1/S

600210 5.613504E-02 -92 65 -66 IMP:N=1 \$ P1 de Ag-In-Cd n.1/I

600310 5.613504E-02 -93 65 -66 IMP:N=1 \$ P1 de Ag-In-Cd n.2/S

600410 5.613504E-02 -94 65 -66 IMP:N=1 \$ P1 de Ag-In-Cd n.2/I

600510 5.613504E-02 -95 65 -66 IMP:N=1 \$ P1 de Ag-In-Cd n.3/S

600610 5.613504E-02 -96 65 -66 IMP:N=1 \$ P1 de Ag-In-Cd n.3/I

600710 5.613504E-02 -97 65 -66 IMP:N=1 \$ Pl de Ag-In-Cd n.4/S

600810 5.613504E-02 -98 65 -66 IMP:N=1 \$ P1 de Ag-In-Cd n.4/I

$\mathrm{C}$

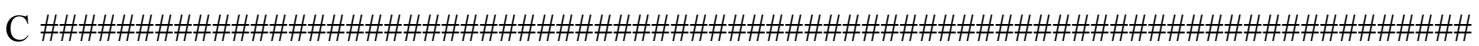

C Celula de agua + placa de Al dos ECC e ECP

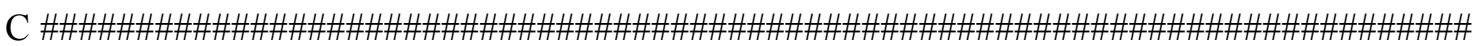

$400026.02442 \mathrm{E}-2 \quad-82 \quad \mathrm{U}=300 \mathrm{IMP}: \mathrm{N}=1$

$40101-1.0 \quad 82 \quad$ U=300 IMP:N=1 


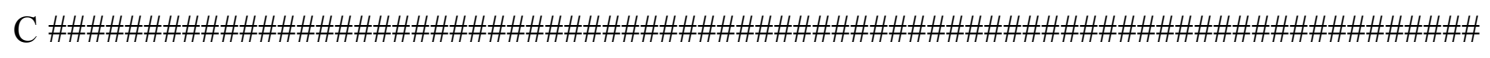

C Celula Combustivel do 101/201

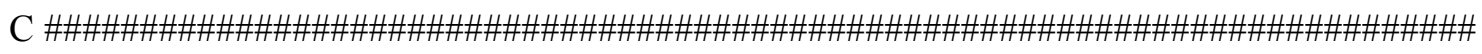

$402021-6.5-83 \quad \mathrm{U}=301$ IMP:N=1

$403026.02442 \mathrm{E}-2-8283$ U=301 IMP:N=1

$40401-1.0 \quad 82 \quad \mathrm{U}=301$ IMP:N=1

C

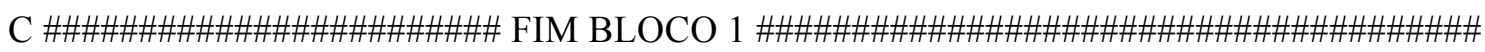

$\mathrm{C} * * * * * * * * * * * * * * * * * * * * * * * * * * * * * * * * * * * * * * * * * * * * * * * * * * * * * * * * * * * * * * * * * * * * * * * * * * *$

C BLOCO 2 SUPERFICIES $* * * * * * * * * * * * * * * * * * * * * * * * * * * * * * * * * * * * * * * * * * * * *$

$\mathrm{C} * * * * * * * * * * * * * * * * * * * * * * * * * * * * * * * * * * * * * * * * * * * * * * * * * * * * * * * * * * * * * * * * * * * * * * * * * * *$

$\mathrm{C} * * * * * * * * * * * * * * * * * * * * * * * * * * * * * * * * * * * * * * * * * * * * * * * * * * * * * * * * * * * * * * * * * * * * * * * * * * *$

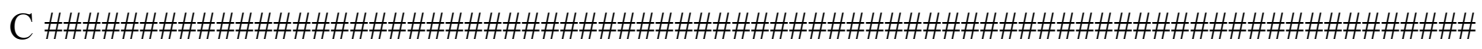

C SISTEMA

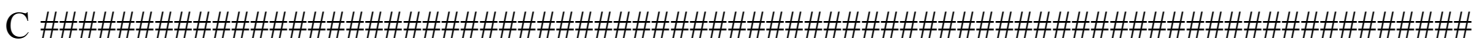

1 RPP $-34.69040 \quad 26.98140 \quad-28.34900 \quad 52.64900 \quad-49.15000 \quad 35.10000$ \$ NUCL

2 RPP $26.98140 \quad 76.98140 \quad-53.34900 \quad 77.64900 \quad-49.15000 \quad 35.10000$ \$ X+

3 RPP $-84.69040-34.69040 \quad-53.3490077 .64900 \quad-49.15000 \quad 35.10000$ \$ X-

4 RPP $-34.6904026 .98140 \quad 52.64900102 .64900 \quad-49.15000 \quad 35.10000$ \$ Y+

5 RPP $-34.69040 \quad 26.98140 \quad-78.34900-28.34900 \quad-49.15000 \quad 35.10000$ \$ Y -

6 RPP $-59.69040 \quad 51.98140 \quad-53.34900 \quad 77.64900 \quad 35.10000 \quad 85.10000$ \$ Z+

7 RPP $-59.69040 \quad 51.98140 \quad-53.3490077 .64900 \quad-99.15000 \quad-49.15000$ \$ Z-

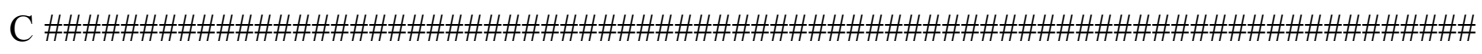

C U 1 NUCLEO GRILLA

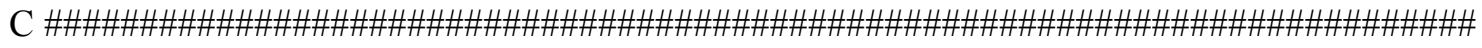

16 RPP $\quad-3.8545 \quad 3.8545 \quad-4.0500 \quad 4.0500 \quad-49.16000 \quad 35.11000 \$$ 


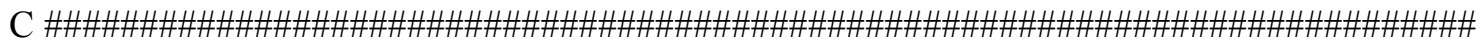

49 RPP $\quad-3.72950 \quad 3.72950 \quad-3.9250 \quad 3.9250 \quad-90.000 \quad 90.000$ \$Base/Al do EIBE

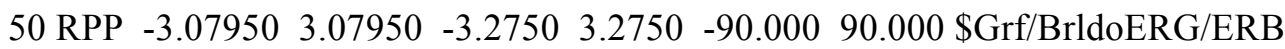

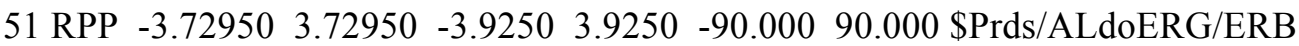

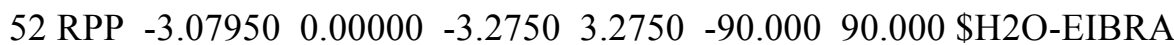

53 RPP $\quad 0.00000 \quad 3.07950 \quad-3.2750 \quad 3.2750 \quad-90.000 \quad 90.000$ \$Berilio-EIBRA

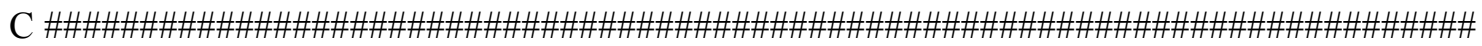

C ZONAS EN Z

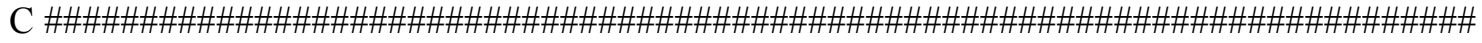

54 PZ -31.250 \$ Base de AL-

55 PZ -36.650 \$ Topo de la Grilla

56 PZ -42.900 \$ Base do Bocal Interno a Grilla (nao usado)

$57 \mathrm{PZ} 35.100$ \$ Topo do $\mathrm{Al}+$

$58 \mathrm{CZ} 2.5$ \$ Agujero Grilla Inf

59 CZ 20.0 \$ AGUJERO Grilla Inf para o Tampao

$60 \mathrm{C} / \mathrm{Z}-1.51 .51 .0$ \$ Canal de Irradiacao n.1 do EIBE

$61 \mathrm{C} / \mathrm{Z} 1.5-1.51 .0$ \$ Canal de Irradiacao n.2 do EIBE

62 PZ 30.0 \$ Topo da Regiao Ativa

$63 \mathrm{PZ} 31.250$ \$ Topo de $\mathrm{Al}+$

64 PZ -30.000 \$ Base da Regiao Ativa

65 PZ 30.000 \$ Base da Barra Absorvedora

66 PZ 85.000 \$ Topo da Barra Absorvedora

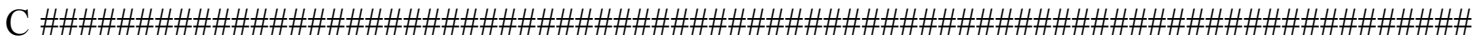

C ZONAS EN X

C 67 PX 50.0 \$ SSW Geracao de Fonte Superficial

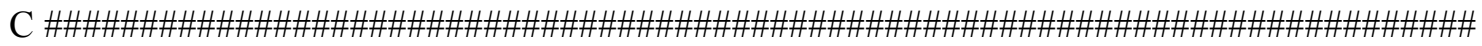

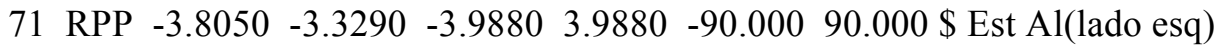

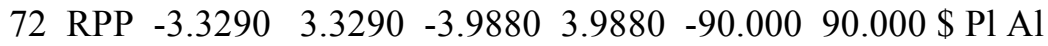




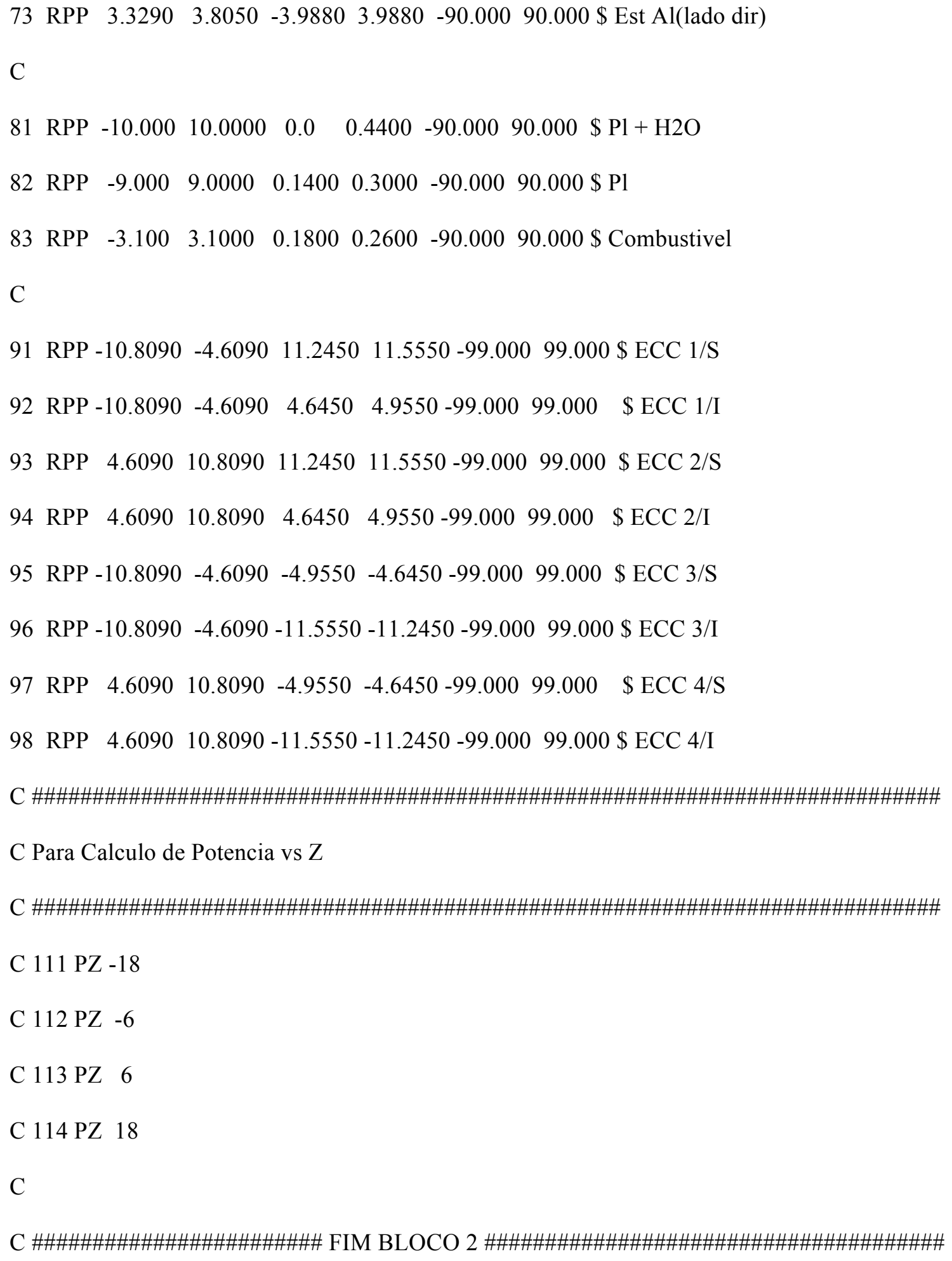


$\mathrm{C} * *$

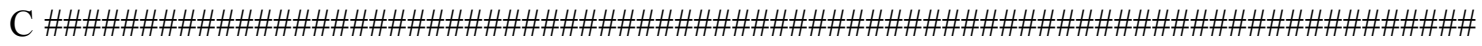

\section{MODE N}

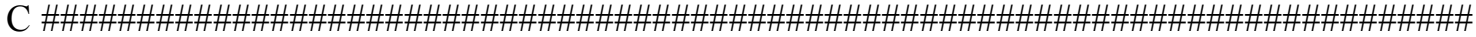

C Calculo kcode

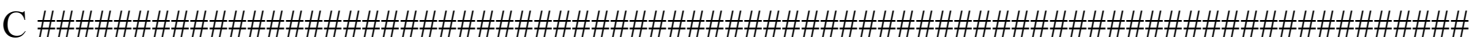

kcode 400001.115200

sdef pos $=0.00 .00 \$$ center vol. source

axs= $\begin{array}{lll}0 & 1\end{array}$ axis vol source

rad d1 $\quad$ \$ radial - distributions 1

ext d2 \$ axial - distributions 2

erg d3 \$ energy - distributions 3

sil $\quad \mathrm{h} \quad 010 \quad \$$ radii vol. source

sp1 -21 1

si2 h -25 25 \$ extension of cylinder

sp3 $\quad-3 \quad$ \$ Watt spectrum

f4:n $(4020<3010[0: 0-9: 8$ 0:0]<1009<10[-2:2 $-2: 2$ 0:0]<1)

E4 0.625E-6 20.00

SD4 29.76

fm4 -1 $21-6$

f14:n $(4020<3220[0: 0-6: 50: 0]<2009<10[-2: 2-2: 20: 0]<1)$

E14 0.625E-6 20.00

SD14 29.76

fm14 -1 $21-6$

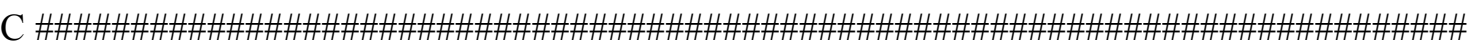

C average flux calculation per fuel element hottest fuel element

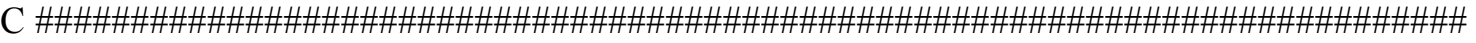

fmesh34:n origin $=-3.1000-4.4000-30.000$ 


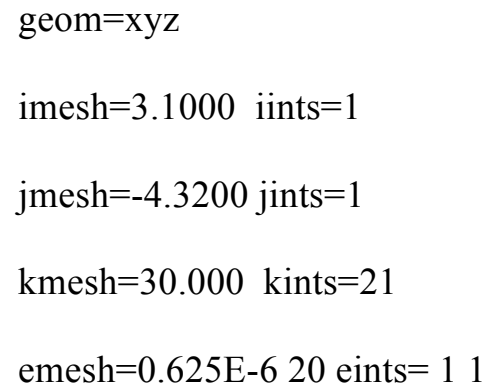

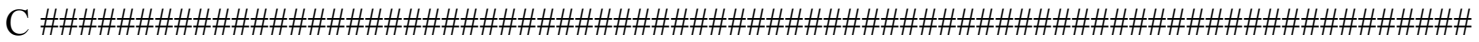

\section{Grafite}

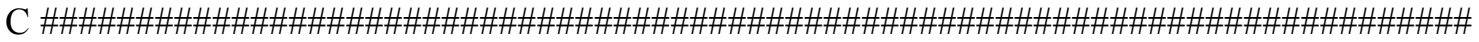
m3 $6000.77 \mathrm{c}-1.0$

mT3 c. $77 \mathrm{t}$

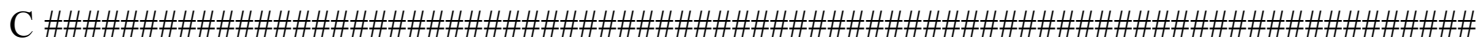

C Berilio

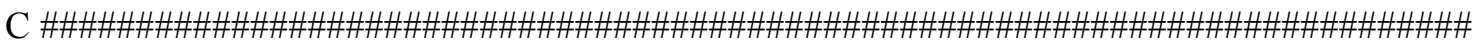
m4 $\quad 4009.77 \mathrm{c}-1.0$ 


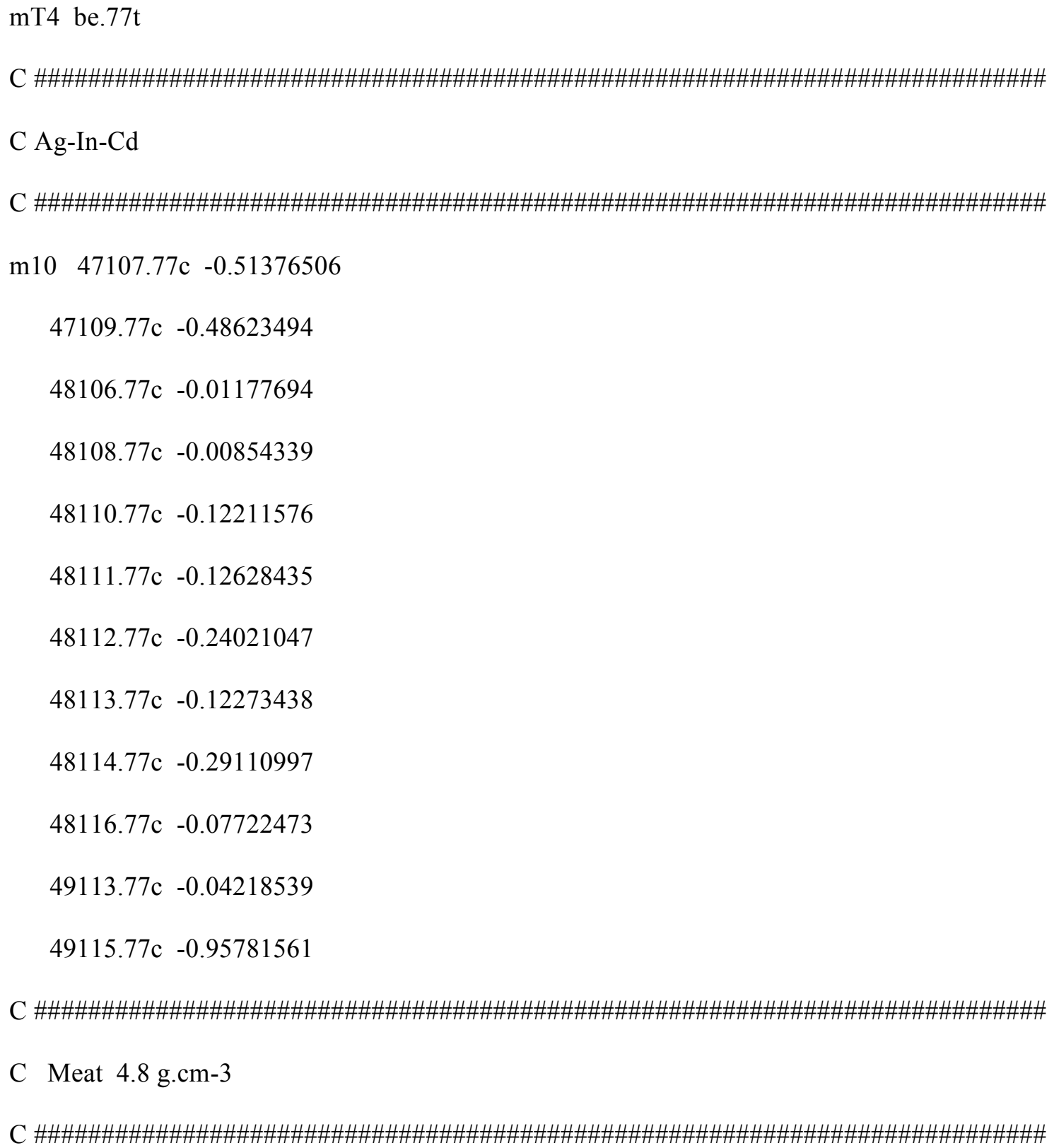




\section{APÊNDICE B}

\section{Input do programa SERPENT: Núcleo 8}

$\%$

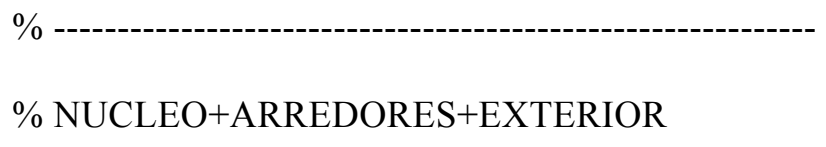

cell 1444 fill 1 -1919293949596979865 -66

cell 132444 fill $1 \quad-1 \quad-65$

cell 123444 fill $1-1 \quad 66$

cell 2444 water $-2 \quad \% \mathrm{X}^{+}$

cell 3444 water $-3 \quad \% \mathrm{X}$ -

cell 4444 water $-4 \quad \% \mathrm{Y}+$

cell 5444 water $-5 \quad \%$ Y-

cell 6444 water $-6919293949596979865-66 \%$ Z+

cell 623444 water $-6 \quad 66 \% \mathrm{Z}+$

cell 632444 water $-6-65 \% \mathrm{Z}+$

cell 7444 water $-7 \quad \%$ Z-

cell 8444 void 1234567 \% EXTERIOR DESPREZADO

$\%$ -
$\%$

$\%$ trans $1-3.8512 .157 .025$

trans $1-3.8512 .150 .0$

cell 6001444 agincd -91 $65-66 \%$ Pl de Ag-In-Cd n.1/S

cell 6002444 agincd -92 $65-66 \%$ Pl de Ag-In-Cd n.1/I

cell 6003444 agincd $-9365-66 \% \mathrm{Pl}$ de Ag-In-Cd n.2/S

cell 6004444 agincd -94 $65-66 \%$ Pl de Ag-In-Cd n.2/I

cell 6005444 agincd $-9565-66 \% \mathrm{Pl}$ de Ag-In-Cd n.3/S

cell 6006444 agincd $-9665-66 \% \mathrm{Pl}$ de Ag-In-Cd n.3/I

cell 6007444 agincd -97 $65-66 \% \mathrm{Pl}$ de Ag-In-Cd n.4/S

cell 6008444 agincd -98 65 -66 \% Pl de Ag-In-Cd n.4/I

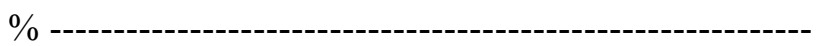

lat 1110.00 .00 .081017 .7098 .1180 .0 


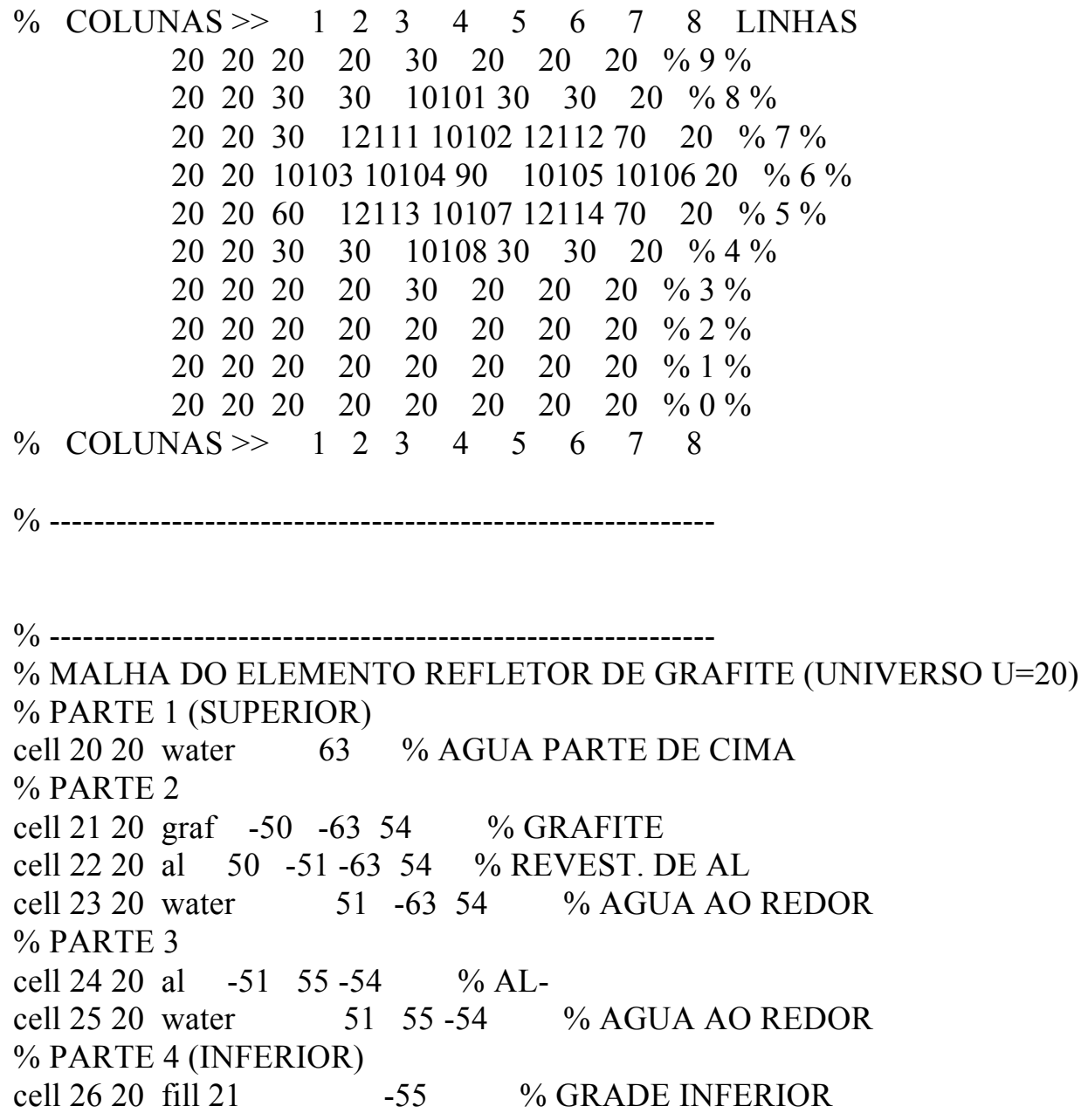




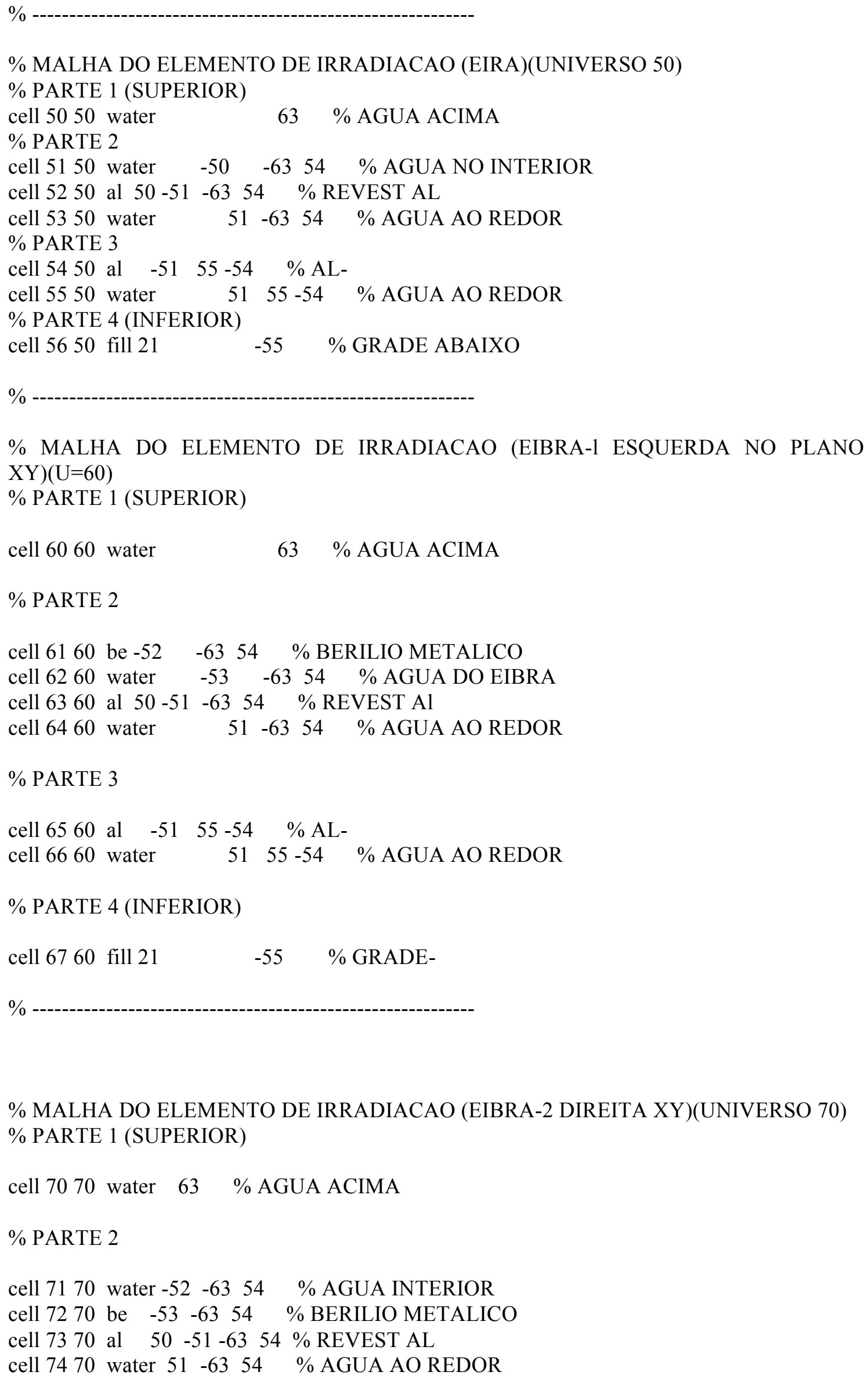


$\%$ PARTE 3

cell 7570 al $\quad-51 \quad 55-54 \quad \%$ AL-

cell 7670 water $51 \quad 55-54 \quad \%$ AGUA AO REDOR

$\%$ PARTE 4 (INFERIOR)

cell 7770 fill $21 \quad-55 \quad \%$ GRADE-

$\%$ MALHA DO ELEMENTO DE IRRADIACAO CENTRAL (EIBE)(UNIVERSO 90)

$\%$ PARTE 1 (SUPERIOR)

cell 9090 water $\quad 63 \%$ AGUA ACIMA

$\%$ PARTE 2

cell 9190 be $\quad-50 \quad 6061 \quad-63 \quad 54 \%$ BERILIO

cell 9290 water $\quad-60 \quad-6354 \%$ CANAL AGUA 1

cell 9390 water $\quad-61 \quad-6354 \%$ CANAL AGUA 2

cell 9490 al $50 \quad-51 \quad-63 \quad 54 \%$ REVEST Al

cell 9590 water $\quad 51 \quad-6354 \%$ AGUA AO REDOR

$\%$ PARTE 3

cell 9690 al $-496061 \quad 55-54 \%$ AL/Base

cell 9790 water $\quad-60 \quad 55-54 \%$ CANAL/AGUA1/Base

cell 9890 water $\quad-61 \quad 55-54 \%$ CANAL AGUA2/Base

cell 9990 water $\quad 49 \quad 55-54 \%$ AGUA AO REDOR

$\%$ PARTE 4 (INFERIOR)

cell 10090 fill $21 \quad-55 \quad \%$ GRADE-

$\%$

$\%$ BOCAL INTERNO A PLACA MATRIZ (UNIVERSO U=21)

cell 11021 water -58

cell 11121 al 58

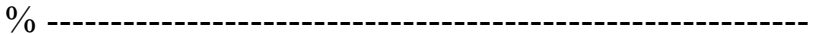

$\%$ BOCAL INTERNO A PLACA MATRIZ (UNIVERSO U=22) (P/TAMPAO)

cell 12022 al -59

cell 12122 void 59 


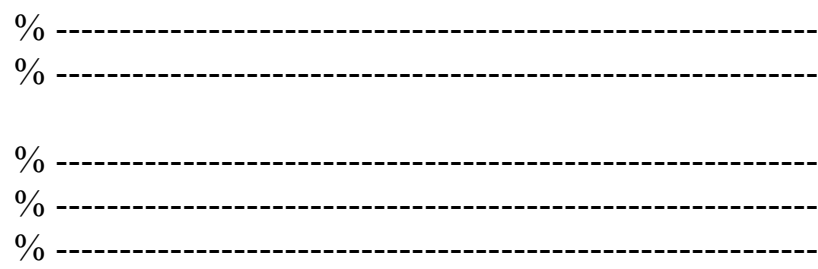

include "mcom_01" include "mcom_02" include "mcom_03" include "mcom_04" include "mcom_05" include "mcom_06" include "mcom_07" include "mcom_08" include "mcom_09" include "mcom_10"

include "comb_01" include "comb_02" include "comb_03" include "comb_04" include "comb 05 " include "comb_06" include "comb_07" include "comb 08" include "comb_09" include "comb 10"

include "mcomc_11" include "mcomc_12" include "mcomc_13" include "mcomc_14"

include "combc_11" include "combc_12" include "combc_13" include "combc_14"

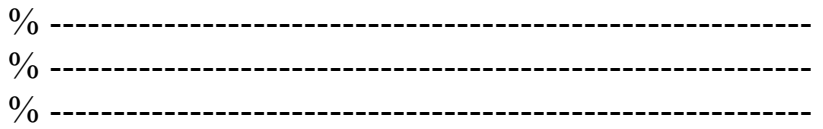

trans $6610.0-0.220 .0$

cell 661661 fill $300-1000$

$\%$

$\%$ Regiao em z de $\mathrm{H} 2 \mathrm{O}+\mathrm{Pl}$ de $\mathrm{Al}$ dos $\mathrm{ECC}$ 
$\% \mathrm{U}=500$ - H2O e PL Al(Malha/ECC) para o $\mathrm{U}=121$

lat 500110.00 .00 .0120110 .00 .4400180 .0

99661996616616616616616616616616616616616616616619966199

\% REGIAO EM Z DE AGUA +P1 DE Al DOS ECP E ECC

$\% \mathrm{U}=200$ - H2O e PL Al(Malha/ECP) para o U=101 a 124

lat 200110.00 .00 .0120110 .00 .4400180 .0

661661661661661661661661661661661661661661661661661661661661

$\%$

$\%$ Celula de agua + placa de $\mathrm{Al}$ dos ECC e ECP

cell 4000300 al -82

cell 4010300 water 82

$\%$

cell 88899 water -1000

cell 9980 fill $444 \quad-999$

cell 9990 outside 999

$\%$

surf 1 cuboid $-34.6500 \quad 26.980-28.34900 \quad 52.64900 \quad-49.15000 \quad 35.10000$

surf 2 cuboid $26.98140 \quad 76.98140 \quad-53.34900 \quad 77.64900 \quad-49.15000 \quad 35.10000$

surf 3 cuboid $-84.69040-34.69040-53.3490077 .64900-49.15000 \quad 35.10000$

surf 4 cuboid $-34.69040 \quad 26.98140 \quad 52.64900102 .64900 \quad-49.15000 \quad 35.10000$

$\begin{array}{lllllll}\text { surf } 5 \text { cuboid }-34.69040 & 26.98140 & -78.34900 & -28.34900 & -49.15000 & 35.10000\end{array}$

surf 6 cuboid $-59.69040 \quad 51.98140 \quad-53.34900 \quad 77.64900 \quad 35.10000 \quad 85.10000$

surf 7 cuboid $-59.69040 \quad 51.98140 \quad-53.3490077 .64900-99.15000-49.15000$

surf $8 \mathrm{pz} 15.0$

surf $9 \mathrm{pz} \quad 0.0$

surf $10 \mathrm{pz}-15.0$

surf 16 cuboid $\quad-3.8545 \quad 3.8545 \quad-4.0500 \quad 4.0500 \quad-49.16000 \quad 35.11000$

surf 49 cuboid $-3.72950 \quad 3.72950 \quad-3.9250 \quad 3.9250 \quad-90.000 \quad 90.000 \%$ Base/Al do EIBE

surf 50 cuboid $\quad-3.07950 \quad 3.07950 \quad-3.2750 \quad 3.2750 \quad-90.000 \quad 90.000 \%$ Grf/BrldoERG/ERB 
surf 51 cuboid $-3.729503 .72950-3.92503 .9250-90.000 \quad 90.000 \%$ Prds/ALdoERG/ERB surf 52 cuboid $-3.07950 \quad 0.00000 \quad-3.2750 \quad 3.2750 \quad-90.000 \quad 90.000 \%$ H2O-EIBRA $\begin{array}{lllllll}\text { surf } 53 \text { cuboid } & 0.00000 & 3.07950 & -3.2750 & 3.2750 & -90.000 & 90.000\end{array} \%$ Berilio-EIBRA

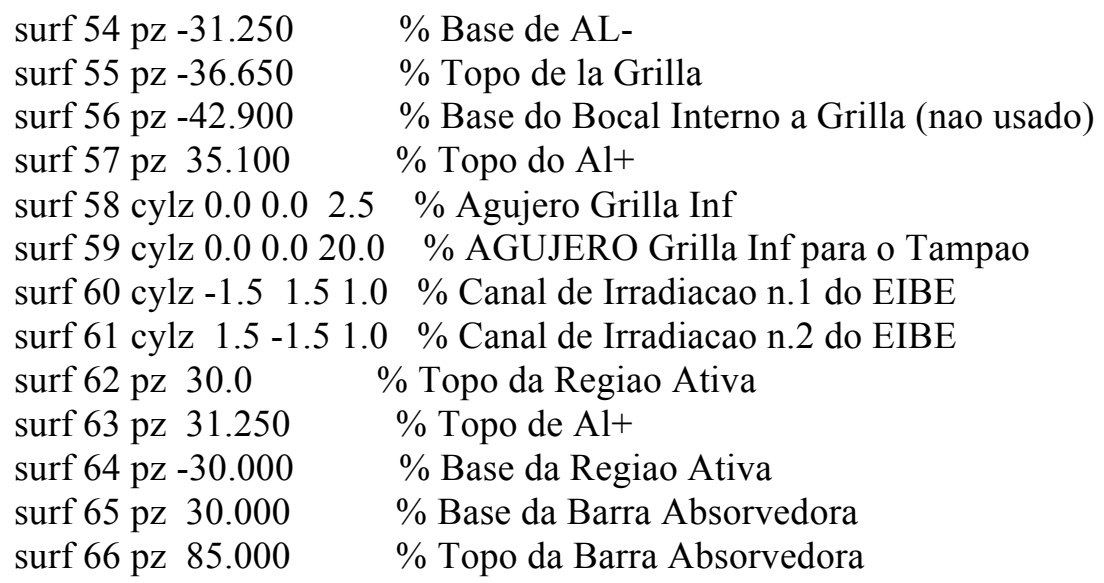

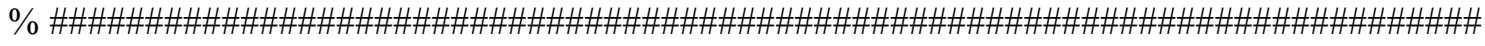

$\%$ MATERIAIS

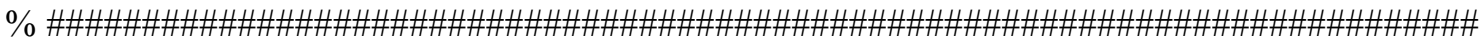
$\%$ Agua

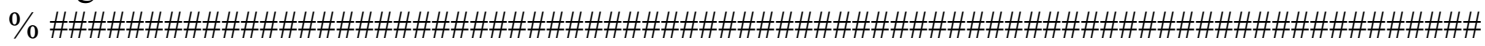
mat water -0.9880729 tmp 323 moder lwtr 1001

$1001.03 \mathrm{c} 2$

8016.03 c 1

therm lwtr lwtr.10t

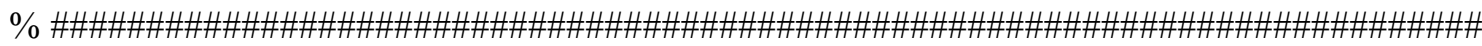
$\%$ Aluminio

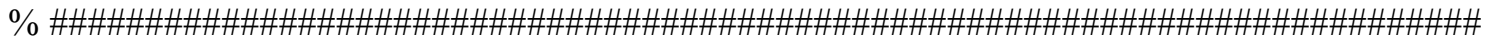
mat al 6.02442E-2 tmp 323 
$13027.03 c-1.0$

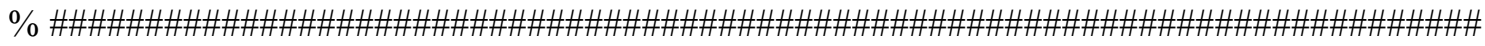

$\%$ Grafite

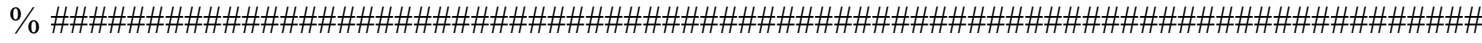
mat graf 8.02261E-2 tmp 323 moder ttg 6000

$6000.03 \mathrm{c}-1.0$

therm ttg grph.10t

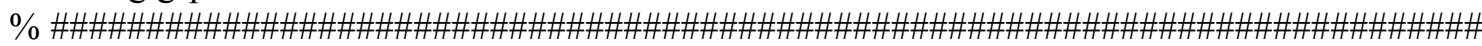

$\%$ Berilio

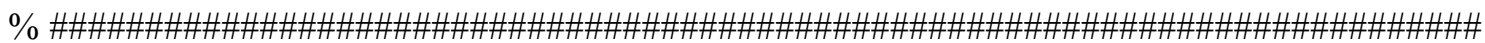
mat be $1.23529 \mathrm{E}-1 \mathrm{tmp} 323$ moder ttb 4009

$4009.03 c-1.0$

therm ttb be. $10 \mathrm{t}$

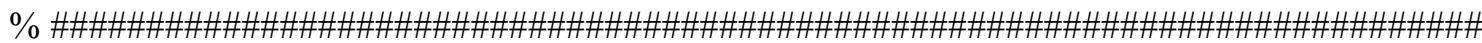
$\%$ Ag-In-Cd

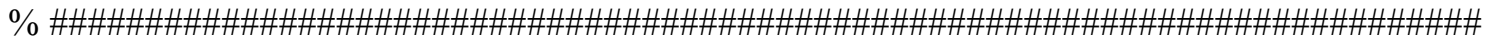
mat agincd 5.613504E-02 tmp 323

47107.03 c -0.51376506

47109.03 c -0.48623494

$48106.03 c-0.01177694$

$48108.03 c-0.00854339$

$48110.03 \mathrm{c}-0.12211576$

$48111.03 \mathrm{c}-0.12628435$

$48112.03 \mathrm{c}-0.24021047$

$48113.03 c-0.12273438$

48114.03 c -0.29110997

48116.03 c -0.07722473

$49113.03 c-0.04218539$

49115.03 c -0.95781561

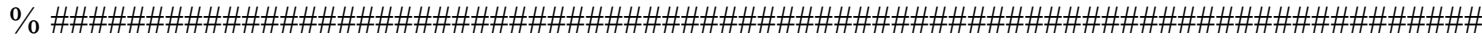

$\% \quad$ Meat 4.8 g.cm-3

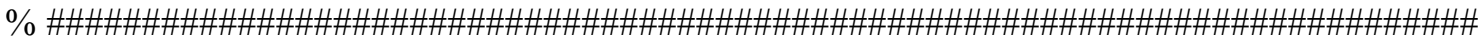
mat meat_1 -6.5 burn 1 vol 1.0 tmp 323

$92234.03 \mathrm{c} \quad 1.90096 \mathrm{E}-05$

$92235.03 \mathrm{c} \quad 1.90740 \mathrm{E}-03$

92238.03 c $7.63373 \mathrm{E}-03$

$13027.03 \mathrm{c} \quad 4.01749 \mathrm{E}-02$

$14028.03 \mathrm{c} \quad 6.11092 \mathrm{E}-03$

$14029.03 \mathrm{c} \quad 3.09422 \mathrm{E}-04$

$14030.03 \mathrm{c} \quad 2.05398 \mathrm{E}-04$

mat meat_2 -6.5 burn 1 vol 1.0 tmp 323

$92234.03 \mathrm{c} 1.90096 \mathrm{E}-05$

$92235.03 \mathrm{c} \quad 1.90740 \mathrm{E}-03$

92238.03c $7.63373 \mathrm{E}-03$

$13027.03 \mathrm{c} \quad 4.01749 \mathrm{E}-02$

$14028.03 \mathrm{c} \quad 6.11092 \mathrm{E}-03$

$14029.03 \mathrm{c} \quad 3.09422 \mathrm{E}-04$

$14030.03 \mathrm{c} \quad 2.05398 \mathrm{E}-04$

mat meat $3-6.5$ burn 1 vol 1.0 tmp 323

$92234.03 \mathrm{c} \quad 1.90096 \mathrm{E}-05$

$92235.03 \mathrm{c} \quad 1.90740 \mathrm{E}-03$

$92238.03 \mathrm{c} \quad 7.63373 \mathrm{E}-03$

$13027.03 \mathrm{c} \quad 4.01749 \mathrm{E}-02$

$14028.03 \mathrm{c} \quad 6.11092 \mathrm{E}-03$

14029.03 c $3.09422 \mathrm{E}-04$ 
$14030.03 \mathrm{c} \quad 2.05398 \mathrm{E}-04$

mat meat $4-6.5$ burn 1 vol $1.0 \mathrm{tmp} 323$

92234.03 c $1.90096 \mathrm{E}-05$

$92235.03 \mathrm{c} \quad 1.90740 \mathrm{E}-03$

$92238.03 \mathrm{c} \quad 7.63373 \mathrm{E}-03$

$13027.03 \mathrm{c} \quad 4.01749 \mathrm{E}-02$

$14028.03 \mathrm{c} \quad 6.11092 \mathrm{E}-03$

$14029.03 \mathrm{c} \quad 3.09422 \mathrm{E}-04$

14030.03 c $2.05398 \mathrm{E}-04$

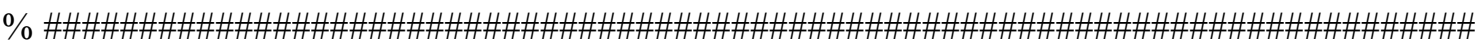

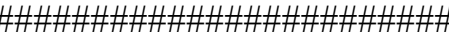

FIM

BLOCO

3

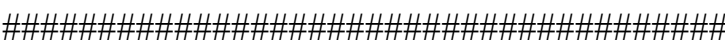

src 2 sx -5.05 .0 sy -5.05 .0 sz -5.05 .0$

$\% \mathrm{yz}$

$\%$ plot 110001000

$\% \mathrm{xz}$

$\%$ plot 210001000

$\%$ xy

$\%$ plot 310001000

plot $2200010001.00-100100-100100$

plot $2200010001.01-100100-100100$

plot $2200010001.02-100100-100100$

plot $2200010001.03-100100-100100$

plot $2200010001.04-100100-100100$

plot $2200010001.05-100100-100100$

plot $2200010001.06-100100-100100$

plot $2200010001.07-100100-100100$

plot $2200010001.08-100100-100100$

plot $2200010001.09-100100-100100$

plot $2200010001.10-100100-100100$

plot $2200010001.11-100100-100100$

plot $2200010001.12-100100-100100$

plot $2200010001.13-100100-100100$

plot $2200010001.14-100100-100100$

$\%$--- Neutron population and criticality cycles:

set pop 100000100020

$\%$--- Total power for normalization: 
set power 5.0E6

$\%$--- optimization

set opti 3

$\%$--- Cross section data library file path:

set acelib "/home/fermium/thiago_garcia/nucleo_8_star/300k/xs/sss_endfb7u.xsdata" set declib "/opt/serpent/xs/sss endfb7.dec"

set nfylib "/opt/serpent/xs/sss_endfb7.nfy"

$\%$--- burn options:

dep daytot 0.10 .50 .751 .02 .04 .05 .010 .030 .060 .0120 .0180 .0240 .0300 .0360 .0

$\%$--- Isotope list for inventory calculation:

set inventory

922340

922350

922360

922380

932370

942380

942390

942400

942410

942420

952410

952430

420990

430990

441010

451030

471090

551330

621470

621490

621500

621510

621520

601430

601450

631530

641550

541260

561330

541280

541290

541300

541310

541320

541330 
541360

541340

541350

481060

481080

481100

481110

481120

481130

481140

481160

420920

420940

420950

420960

420970

420980

420990

421000

201

202

set printm 1

$\%$--- optimization

set opti 1 


\section{APÊNDICE C}

\section{Input do Modelo Térmico MTRCR-IEAR1}

\{Simulação simplificada do Elmento que possui a placa mais quente $-4.8 \mathrm{gU} / \mathrm{cm} 3$

Analise Conservativa

U3Si2-Al

MAXIMA TEMP. ENT.42 C \}

\{Definicao de algumas funcoes para facilitar na solucao\}

\{Funcao para calculo do Numero de Reynolds\}

FUNCTION rey $(\mathrm{m} 1 ; \mathrm{dh} 1 ; \mathrm{mi} 1 ; \mathrm{ae} 1)$

rey: $=\mathrm{m} 1 * \mathrm{dh} 1 /(\mathrm{mi} 1 * \mathrm{ae} 1)$

END

\{Funcao para calculo do Numero de Prandtl\}

FUNCTION prn $(\mathrm{cp} 1 ; \mathrm{mi} 1 ; \mathrm{k} 1)$

prn: $=\mathrm{cp} 1 * \mathrm{mi} 1 / \mathrm{k} 1$

END

\{determinacao do coeficiente de pelicula\}

FUNCTION h(k;dh;re;pr)

$$
\begin{aligned}
& \mathrm{ht}:=0,027 *\left(\mathrm{re} * * 0,8 * \mathrm{pr}^{* *} 0,33\right) * \mathrm{k} / \mathrm{dh} \\
& \mathrm{hl}:=4,0 * \mathrm{k} / \mathrm{dh} \\
& \text { hlt: }=((\mathrm{re}-2000) * \mathrm{ht}+(4000-\mathrm{re}) * \mathrm{hl}) / 2000 \\
& \text { if }(\mathrm{re}>4000) \text { Then } \\
& \quad \mathrm{h}:=\mathrm{ht}
\end{aligned}
$$

Else

$$
\begin{aligned}
& \text { if }(\mathrm{re}<2000) \text { Then } \\
& \mathrm{h}:=\mathrm{hl}
\end{aligned}
$$

Else

$$
\mathrm{h}:=\mathrm{hlt}
$$

Endif

Endif

END 
$\mathrm{n}=21 \quad$ número de volumes axiais $\}$

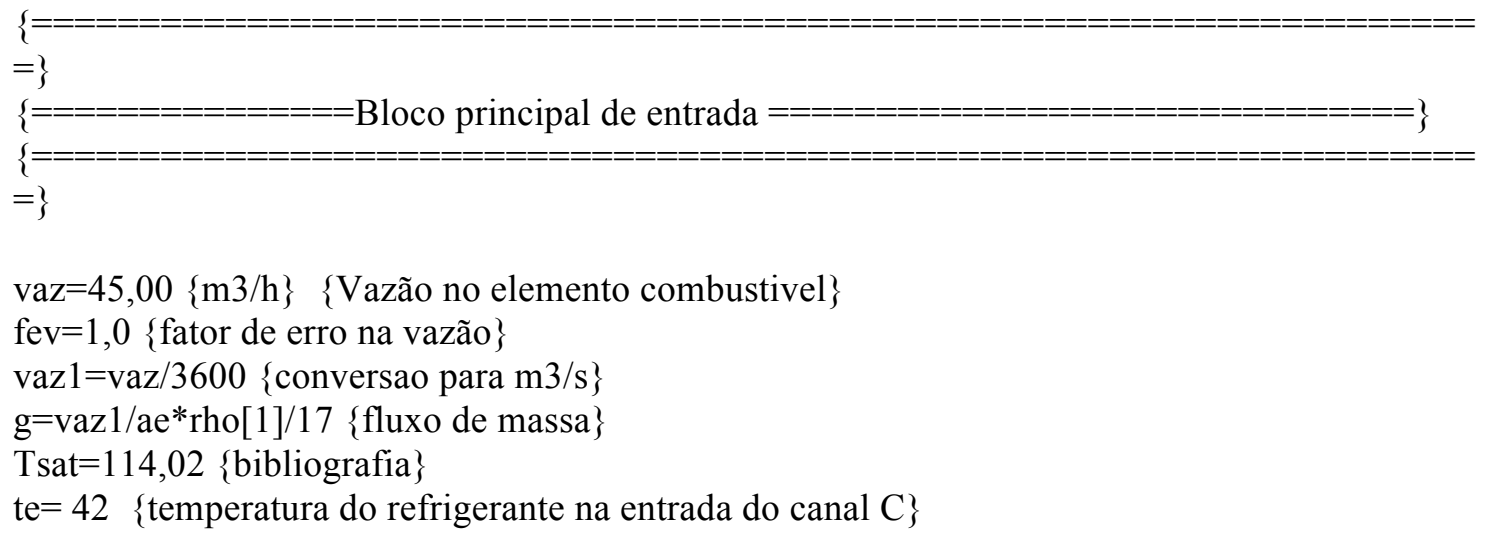

Ncont $=4$

Nfuel $=8$

Ntp $=18 *$ Nfuel $+12 *$ Ncont $\{$ No. total de mini-placas comb. $\}$

$\mathrm{Vtc}=\mathrm{Ntp} * \mathrm{vtp}\{$ vol. totaldas mini placas $\}$

Pop $=4737963,09\{$ Pot. de operacao $\}\{5000000\}$

$\{$ cor $=1\{\mathrm{COR}=1 \gg>>>$ Bergles\&Rohsenow; COR $=0 \gg>>>$ Dittus \& Boelter $\}\}$

$\mathrm{f}=1,0$ fatores de incerteza $\}$

$\{==$
$==$

\{dados - canal/placa\}

$\mathrm{Hp}=0,600$ \{altura da placa em $\mathrm{m}\}$

$\{\mathrm{Hc}=170,0\}$

$\mathrm{Lc}=67,1 \mathrm{e}-3$ \{largura do Canal em $\mathrm{m}\}$

$\mathrm{Lp}=62,0 \mathrm{e}-3$ \{largura ativa da placa $\mathrm{em} \mathrm{m}\}$

$\mathrm{Ep}=1,52 \mathrm{e}-3$ \{espessura total da placa $\mathrm{m}\}$

$\mathrm{Ef}=0,80 \mathrm{e}-3$ espessura do fuel $\}$

$\mathrm{Er}=0,38 \mathrm{e}-3$ \{espessura do revestimento $\}$

$\mathrm{Ec}=2,89 \mathrm{e}-3$ \{espessura do canal em $\mathrm{m}\}$

DUPLICATE $\mathrm{I}=0 ; \mathrm{n}-1$

$\mathrm{m}[\mathrm{i}+1]=\mathrm{fev}^{*} \mathrm{vaz} 1{ }^{*}$ rho $[\mathrm{i}+1] / 17$ \{ vazao massica por canal $\mathrm{kg} / \mathrm{s}$ Div 13 canais \}

END

$\mathrm{P} 1=1,63$ \{pressão de operacão \}

$\mathrm{ae}=\mathrm{Lc} * \mathrm{Ec} \quad\{$ area de escoamento de um canal em $\mathrm{m} 2\}$

$\mathrm{Pm}=2 *(\mathrm{Ec}+\mathrm{Lc})\{$ perimetro molhado

$\mathrm{at}=\mathrm{Hp} *((\mathrm{Lp}+\mathrm{Lc}) / 2) \quad\{$ area de troca de cond. em m2 PEDRO

atr $=$ at $/ \mathrm{n}$ \{area de troca por região

$\mathrm{dh}=4 * \mathrm{ae} / \mathrm{Pm} \quad\{$ diametro hidraulico em $\mathrm{m}$ \}

$\{\mathrm{vtp}=\mathrm{Ef} * \mathrm{Lp} * \mathrm{Hp}\} \quad\{$ volume total de combustivel P/ 1 mini-placa $\mathrm{m} 3\}$

$\mathrm{vtp}=29,76$

$\mathrm{vtr}=\mathrm{vtp} / \mathrm{n} \quad\{$ volume total por regiao $\}$ 
$\{$ propriedades fisicas no SI\}

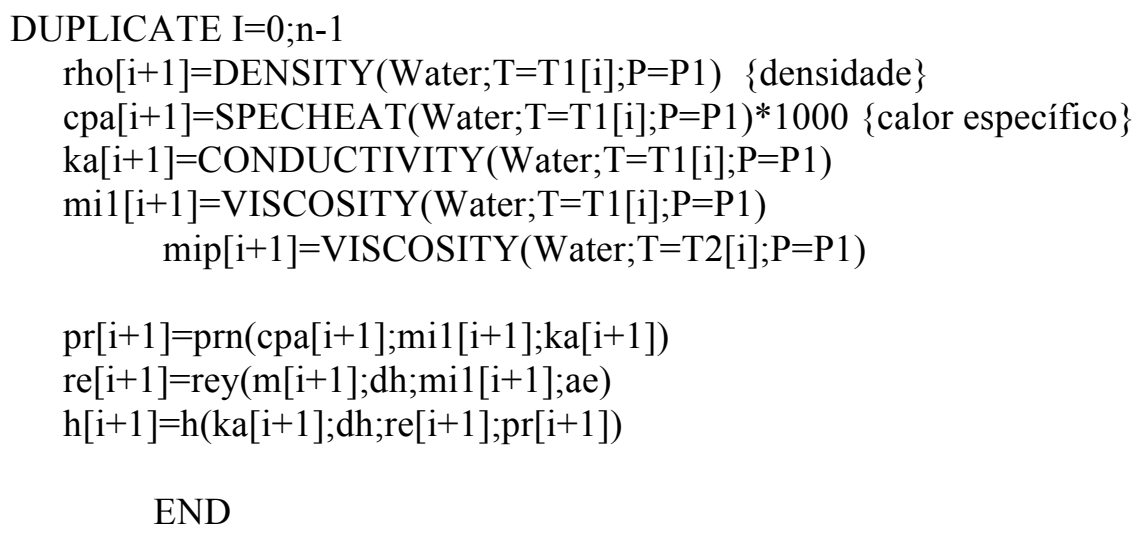

\{equacoes de balanco para regime permanente - Válidas para todo o domínio\}

DUPLICATE $\mathrm{i}=0 ; \mathrm{n}-1$ 


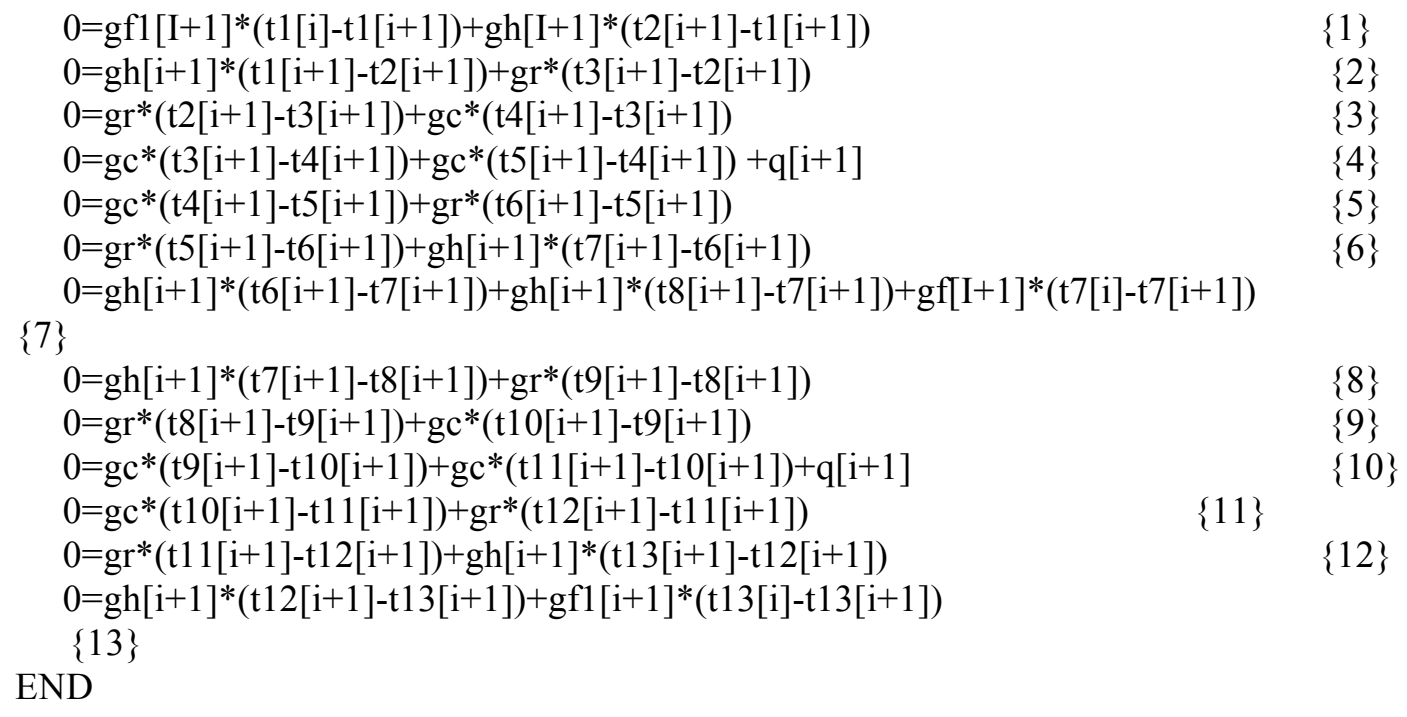


$\mathrm{vV}=0,33$

dtsub=Tsat-T1[n]

$\operatorname{pot} 3=\operatorname{sum}(\mathrm{ql}[\mathrm{i}] ; \mathrm{i}=1 ; 20)$

DUPLICATE $\mathrm{i}=1 ; \mathrm{n}$

hvap $[\mathrm{i}]=$ Lookup('teste.lkt';i;3)

END

media $=\operatorname{pot} 3 / \mathrm{n}$

DUPLICATE $\mathrm{I}=1 ; \mathrm{n}$

DTS[i] $=$ Tsat- $\mathrm{t} 1[\mathrm{n}]$

$\mathrm{qc}[\mathrm{i}]=145,4 *$ teta $^{*}\left(\left(1+2,5 *\left(\mathrm{vel}^{*} 100\right) * * 2 /\right.\right.$ teta $\left.) * * 0,25\right) *(1+15,1 * \operatorname{cpa}[\mathrm{i}] * \mathrm{DTS}[\mathrm{n}] /(\mathrm{hvap}[\mathrm{i}] * \mathrm{p} 1 * * 0,5$ )$) / 10000\{$ LABUNTSOV $\}$

$\mathrm{qcm}[\mathrm{i}]=151 *(1+0,1198 * \mathrm{vel}) *(1+0,00914 * \mathrm{dtsub}) *(1+0,19 * \mathrm{P} 1)\{$ Mirshak

$\mathrm{q} 1[\mathrm{i}]=\mathrm{q}[\mathrm{i}] /(2 * \operatorname{atr} * 10000) \quad\{\mathrm{W} / \mathrm{cm} 2\}$

$\operatorname{MDNBR}[\mathrm{i}]=\mathrm{qc}[\mathrm{i}] / \mathrm{q} 1[\mathrm{i}]$

MIRSHAK $[\mathrm{i}]=\mathrm{qcm}[\mathrm{i}] / \mathrm{ql}[\mathrm{i}]$

MI $[\mathrm{i}]=151 *\left(1+0,1198^{*} \mathrm{vel}\right) *(1+0,00914 *($ Tsat-t $1[\mathrm{n}])) *\left(1+, 19^{*} \mathrm{p} 1\right)\{$ OK com PARET $\}$

$\mathrm{cmi}[\mathrm{i}]=\mathrm{mi}[\mathrm{i}] / \mathrm{q} 1[\mathrm{i}]$

END

$\{$ INSTABILIDADE DE FLUXO

CORRELAÇÃO DE

Whttle e forgan

\}

eta $=25$

dhe $=4 *$ ae $/(2 *$ Lp $+2 *$ ec $)$

$\mathrm{R}=1 /(1+\mathrm{eta} *(\mathrm{dhe} / \mathrm{Hp}))$

$\mathrm{fmc}=\mathrm{Pop} /(2 * \mathrm{at} * \mathrm{Ntp})$

DUPLICATE $\mathrm{I}=1 ; \mathrm{n}$

qifc $[\mathrm{i}]=\mathrm{vel} *(\mathrm{Lp} * \mathrm{Ec}) /(2 *(\mathrm{Lp})) / \mathrm{Hp} *($ Tsat-T1[1] $) * \mathrm{rho}[1] * \mathrm{cpa}[1]$

$\mathrm{FIR}[\mathrm{i}]=\mathrm{qifc}[\mathrm{i}] / \mathrm{fmc}$

END 


\section{APÊNDICE D}

\section{Input do Programa LOSS}

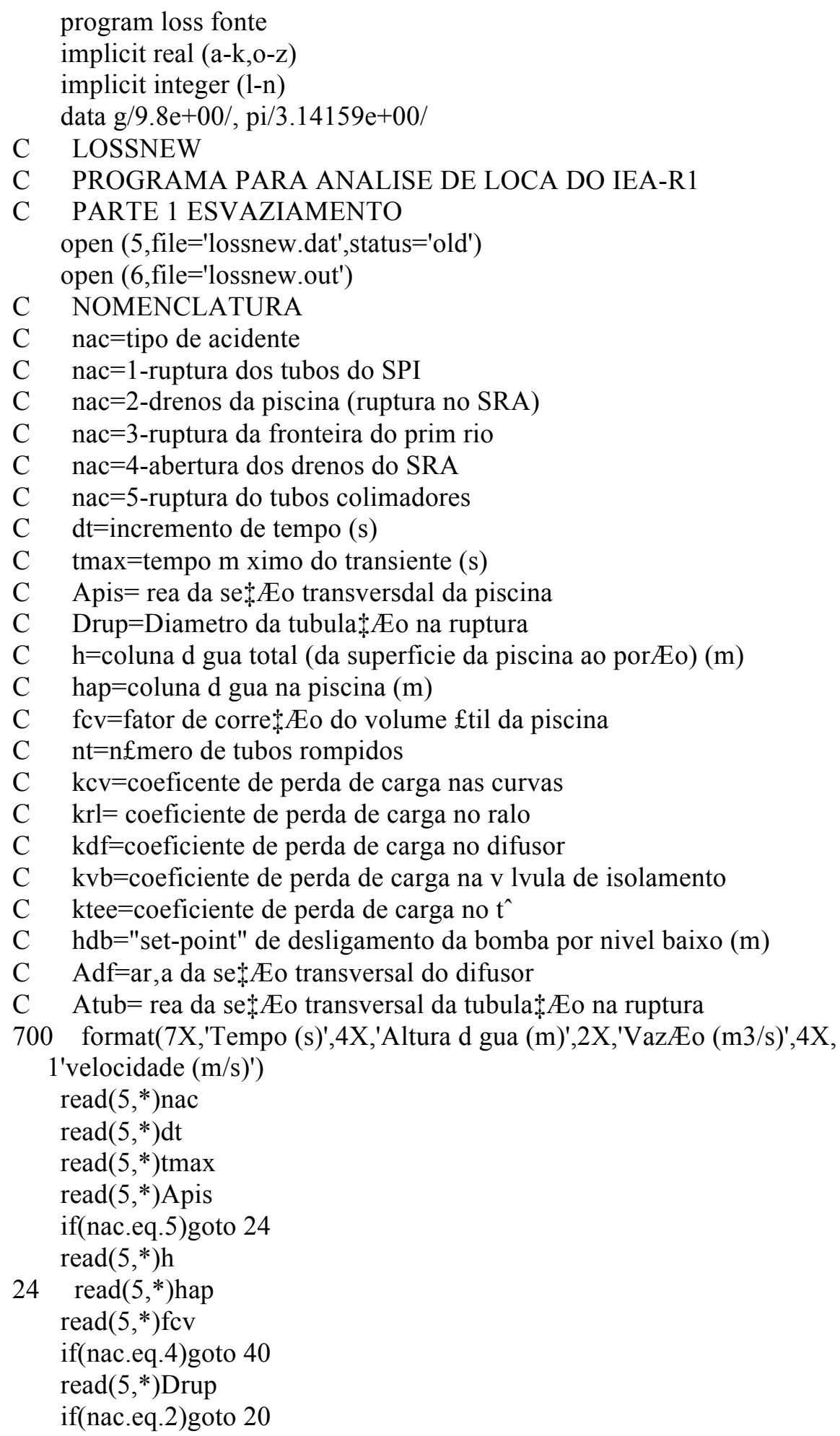


if(nac.eq.3)goto 30

if(nac.eq.4)goto 25

$\operatorname{read}\left(5,{ }^{*}\right) \mathrm{nt}$

if(nac.eq.5)goto 25

goto 40

$20 \operatorname{read}(5, *) \mathrm{kcv}$

$\operatorname{read}(5, *) \mathrm{krl}$

goto 40

$25 \operatorname{read}\left(5,{ }^{*}\right) \mathrm{kbh}$

$\operatorname{read}(5, *)$ hmin

goto 40

$30 \operatorname{read}(5, *) \mathrm{kcv}$

$\operatorname{read}(5, *) \mathrm{kdf}$

$\operatorname{read}(5, *) \mathrm{kvb}$

$\operatorname{read}\left(5,{ }^{*}\right) \mathrm{ktee}$

$\operatorname{read}(5, *) \mathrm{hdb}$

$\operatorname{read}\left(5,{ }^{*}\right) \mathrm{Adf}$

$\operatorname{read}(5, *)$ Atub

40 close (5)

vel $=0$

time $=0.0 \mathrm{e}+00$

if(nac.eq.5)goto 201

C Coeficiente da curva da bomba

$\mathrm{A} 0=26.2$

$\mathrm{A} 1=216.5$

$\mathrm{A} 2=-2209.7$

A $3=8048.0$

$\mathrm{A} 4=-12784.2$

$\mathrm{ddh}=\mathrm{h}-\mathrm{hap}$

$\mathrm{hdbt}=\mathrm{hdb}+\mathrm{ddh}$

if(nac.eq.4)goto 400

Arup $=$ pi* $\left(\right.$ drup $\left.^{* * 2.0}\right) / 4.0$

if(nac.eq.1)goto 100

if(nac.eq.2)goto 200

if(nac.eq.3)goto 300

if(nac.eq.4)goto 400

C nac $=1$-Ruptura dos Coelhos

$100 \mathrm{D}=2.0 /\left(2 .{ }^{*} \mathrm{~g} *\right.$ Arup $\left.{ }^{* *} 2.\right)$

110 write $(6, *)$ time,hap,Q,vel

time $=$ time $+\mathrm{dt}$

$\mathrm{Q}=\operatorname{sqrt}(\mathrm{h} /(\mathrm{D}))$

$\mathrm{Q}=\mathrm{nt} * \mathrm{Q}$

$\mathrm{h}=\mathrm{h}-\mathrm{dt} * \mathrm{Q} /($ Apis/fcv)

vel $=\mathrm{Q} /$ Arup

hap $=$ h-ddh

if((time.lt.tmax).and.(hap.gt.0.))goto 110

goto 800

C nac $=2$-Ruptura no Sistema de Retratamento

$200 \mathrm{C}=(\mathrm{kcv}+\mathrm{krl}) /(2.0 * \mathrm{~g} *$ Arup* $)$

$\mathrm{D}=2.0 /(2.0 * \mathrm{~g} *$ Arup $* * 2)$

210 write $\left(6,{ }^{*}\right)$ time,hap,Q,vel

time $=$ time $+\mathrm{dt}$

$\mathrm{Q}=\operatorname{sqrt}(\mathrm{h} /(\mathrm{D}))$

$\mathrm{h}=\mathrm{h}-\mathrm{dt} * \mathrm{Q} /($ Apis/fcv)

vel $=\mathrm{Q} /$ Arup 
hap $=$ h-ddh

if((time.lt.tmax).and.(hap.gt.0.))goto 210

goto 800

$\mathrm{C}$ nac $=3$-Ruptura do Prim rio (com Bomba)

$300 \mathrm{~B}=\mathrm{kdf} /\left(2.0 * \mathrm{~g} * \mathrm{Adf}^{*} * 2\right)$

$\mathrm{C}=(\mathrm{ktee}+\mathrm{kcv}+\mathrm{kvb}) /\left(2.0^{*} \mathrm{~g} * \mathrm{Atub}^{* *} 2\right)$

$\mathrm{D}=1.0 /\left(2{ }^{*} \mathrm{~g} *\right.$ Arup $\left.* * 2\right)$

310 write $(6, *)$ time,hap, QT, vel

time $=$ time $+\mathrm{dt}$

$\mathrm{QD}=\operatorname{sqrt}(\mathrm{h} /(\mathrm{B}+\mathrm{C}+\mathrm{D}))$

if(h.lt.hdbt)goto 370

do $350 \mathrm{l}=1,1000000$

$\mathrm{dQB}=1 / 100000$.

$\mathrm{QB}=0.2+\mathrm{dQB}$

$\mathrm{hb}=(\mathrm{QB} * * 2) / 0.0614-\mathrm{h}+255.0 * \mathrm{QB} * * 2$

$\mathrm{x}=\mathrm{QB}$

$\mathrm{y}=\mathrm{A} 0+\mathrm{A} 1 * \mathrm{x}+\mathrm{A} 2 * \mathrm{x} * * 2+\mathrm{A} 3 * \mathrm{x} * * 3+\mathrm{A} 4 * \mathrm{x} * * 4$

$\mathrm{DDA}=\mathrm{ABS}(\mathrm{HB}-\mathrm{Y})$

IF(DDA.LT.0.01)goto 351

350 continue

$351 \quad \mathrm{QT}=\mathrm{QD}+\mathrm{QB}$

$\mathrm{h}=\mathrm{h}-\mathrm{dt} * \mathrm{QT} /($ Apis $/ \mathrm{fcv})$

vel $=\mathrm{QD} /$ Arup

hap $=$ h-ddh

goto 375

$370 \quad \mathrm{QBL}=\operatorname{sqrt}(\mathrm{h} /(1 / 0.0614+255))$

$\mathrm{QB}=\mathrm{QBL}$

goto 351

375 if((time.lt.tmax).and.(hap.gt.0.))goto 310

goto 800

C nac $=4$-abertura dos drenos do SRA

400 time $=0.0 \mathrm{e}+00$

410 write $\left(6,{ }^{*}\right)$ time,hap,QT,vel

time $=$ time $+\mathrm{dt}$

$\mathrm{k} 1=4109147.0$

$\mathrm{Q} 1=\operatorname{sqrt}(\mathrm{h} / \mathrm{k} 1)$

$\mathrm{k} 2=4109147.0$

$\mathrm{Q} 2=\operatorname{sqrt}(\mathrm{h} / \mathrm{k} 2)$

$\mathrm{k} 3=1.325 \mathrm{E} 11$

$\mathrm{Q} 3=\operatorname{sqrt}(\mathrm{h} / \mathrm{k} 3)$

$\mathrm{k} 4=2.865 \mathrm{E} 08$

$\mathrm{Q} 4=\operatorname{sqrt}(\mathrm{h} / \mathrm{k} 4)$

$\mathrm{k} 5=9301193.0$

$\mathrm{Q} 5=\operatorname{sqrt}(\mathrm{h} / \mathrm{k} 5)$

$\mathrm{k} 6=7334400.0$

$\mathrm{Q} 6=\mathrm{sqrt}(\mathrm{h} / \mathrm{k} 6)$

$\mathrm{Q}=\mathrm{Q} 1+\mathrm{Q} 2+\mathrm{Q} 3+\mathrm{Q} 4+\mathrm{Q} 5+\mathrm{Q} 6$

$\mathrm{h}=\mathrm{h}-\mathrm{dt} * \mathrm{Q} /($ Apis/fcv)

hap $=$ h-ddh

if((time.lt.tmax).and.(hap.gt.0.))goto 410

goto 800

C nac-5 Ruptura dos Tubos de IrradiałÆEo

201 hef=hap-hmin

Arup $=\mathrm{pi} *\left(\right.$ drup $\left.^{* * 2.0}\right) / 4.0$

$\mathrm{C}=(\mathrm{kbh}) /(2.0 * \mathrm{~g} *$ Arup $* 2)$ 
$\mathrm{D}=2.0 /(2.0 * \mathrm{~g} *$ Arup**2)

211 write $\left(6,{ }^{*}\right)$ time,hap,QT,vel

time $=$ time $+\mathrm{dt}$

$\mathrm{Q}=\operatorname{sqrt}($ hef $/(\mathrm{C}+\mathrm{D}))$

hef $=$ hef-dt*Q/(Apis/fcv)

$\mathrm{vel}=\mathrm{Q} /$ Arup

hap $=$ hef + hmin

if((time.lt.tmax).and.(hap.gt.hmin))goto 211

800 close $(6)$

end 


\section{APÊNDICE E}

\section{Input do Programa TEMPLOCA}

program temploca

implicit real(a-h,m-z)

implicit integer(i-1)

character tit*40

open $(5$, file $=$ 'temploca.dat', status $=$ 'old' $)$

open(6,file='temploca.out',status='unknown')

C PM-Potencia de operacao $\mathrm{m}$, dia por elemento (MW)

C TMAX-tempo maximo do transiente (s)

C TLAG-tempo entre o desligamento do reator e o descobrimento do nucleo (s)

C TIFC-temperatura do combustivel no instante inicial apos o descobrimento (C)

C TARC-temperatura inicial do ar após o descobrimento (C)

C fr-fator de potencia radial do elemento analisado

C fs-fator de incerteza para a potencia de decaimento

C fsp-fator de sobrepotencia

C IMCP-opcao para a massa e o calor especifico

C IMCP=1-utilizacao do fator de corre $Æ$ fmcp

C IMCP=2-utilizacao das massas e dos calores especificos do U3O8

C fmcp-fator de correcao da massa e do calor especifico

C MAL-massa de aluminio do elemento combustivel $(\mathrm{kg})$

C MFU-massa de combustivel do elemento combustivel (kg)

C WU- fracao em peso de U na dispersao

C icdec-opcao para escolha da curva de decaimento.

C icdec=1-equa $\$$ Eo de Way-Wigner;

C icdec $=2$-equa $\$$ Eo de decaimento exponencial.

C TO-tempo de operacao do reator anterior ao seu desligamento (ou tempo de irradiacao) (s)

C A0, A1, A2, A3, k0, k1, k2, e k3-coeficiente da equação de decaimento exponencial

(somente utilizados se idec $=2$ )

$\operatorname{read}(5,10)$ tit

10 format(A40)

$\operatorname{read}(5, *) \mathrm{pm}$

$\operatorname{read}(5, *) \operatorname{tmax}$

$\operatorname{read}(5, *)$ tlag

$\operatorname{read}(5, *)$ fr

$\operatorname{read}(5, *) \mathrm{fs}$

C $\operatorname{read}\left(5,{ }^{*}\right) \mathrm{fg}$

$\operatorname{read}(5, *)$ fsp

$\operatorname{read}(5, *)$ imcp

if(imcp.eq.2)goto 20

$\operatorname{read}(5, *) \mathrm{fmcp}$

goto 30

$20 \operatorname{read}\left(5,{ }^{*}\right) \mathrm{mal}$

$\operatorname{read}\left(5,{ }^{*}\right) \mathrm{mfu}$

$\operatorname{read}(5, *) \mathrm{wu}$

$30 \operatorname{read}(5, *)$ tifc

$\operatorname{read}\left(5,{ }^{*}\right) \operatorname{tarc}$ 
$\operatorname{read}(5, *)$ icdec

if(icdec.eq.2)goto 40

$\operatorname{read}\left(5,{ }^{*}\right)$ to

$\operatorname{read}(5, *) \mathrm{w}$

C $\quad \mathrm{w}=6.22 \mathrm{e}-02$

$\mathrm{x}=-0.2$

$\mathrm{y}=0.2$

goto 50

$40 \operatorname{read}\left(5,{ }^{*}\right) \mathrm{x} 0, \mathrm{y} 0, \mathrm{t} 1, \mathrm{a} 1, \mathrm{t} 2, \mathrm{a} 2, \mathrm{t} 3, \mathrm{a} 3$

en $=2.718282$

50 write $(6,60)$ tit

60 format $(\mathrm{a} 40 / /)$

write $(6,70)$

70 format $(5 \mathrm{x}$,'tempo (s)',6x,'temperatura(C)'/)

C $\mathrm{p}=\mathrm{pm} * \mathrm{fr} * \mathrm{fs} * \mathrm{fg} * \mathrm{fsp}$

$\mathrm{p}=\mathrm{pm} * \mathrm{fr} * \mathrm{fs} * \mathrm{fsp}$

C

$\mathrm{t}=0.0$

$\mathrm{dt}=1$.

$\mathrm{td}=\mathrm{t}+$ tlag

tc $=$ tifc

tif $=($ tifc*9./5. $)+32$.

$\operatorname{tar}=(\operatorname{tarc} * 9 . / 5)+$.32 .

$\mathrm{dth}=$ tif-tar

ddth $=0$.

80 continue

$\mathrm{td}=\mathrm{td}+\mathrm{dt}$

if(imcp.lt.2)goto 90

$\mathrm{cpal}=0.892+0.00046 * \mathrm{tc}$

cpfu $=0.892+0.00046 *$ tc-wu $*(0.734+0.00019 *$ tc $)$

$\mathrm{m}=\mathrm{mal}+\mathrm{mfu}$

$\mathrm{mcp}=1.055 \mathrm{e}-3 *((\mathrm{mal} * 2.205 * \mathrm{cpal} * 0.239)+(\mathrm{mfu} * 2.205 * \mathrm{cpfu} * 0.239))$

90 if(icdec.eq.2)goto 100

$\mathrm{a}=\mathrm{td}^{* * \mathrm{x}}$

$\mathrm{b}=(\mathrm{td}+\mathrm{to}) * * \mathrm{x}$

$\mathrm{q}=\mathrm{w}^{*} \mathrm{p} *(\mathrm{a}-\mathrm{b})$

goto 110

$100 \mathrm{y}=\mathrm{y} 0+\mathrm{a} 1 * \mathrm{en} * *(-(\mathrm{td}-\mathrm{x} 0) / \mathrm{t} 1)+\mathrm{a} 2 * \mathrm{en} * *(-(\mathrm{td}-\mathrm{x} 0) / \mathrm{t} 2)+\mathrm{a} 3 * \mathrm{en} * *(-(\mathrm{td}-\mathrm{x} 0)$

$1 / \mathrm{t} 3)$

$\mathrm{q}=\mathrm{y}^{*} \mathrm{p}$

110 if(imcp.eq. 1$)$ goto 120

ddth $=(\mathrm{q}-\mathrm{dth} *(1.3 \mathrm{e}-06 *(6.4 \mathrm{e}-03 * \mathrm{dth} * 0.72+0.5))) *(\mathrm{dt} /(\mathrm{mcp}))$

goto 130

$120 \mathrm{ddth}=(\mathrm{q}-\mathrm{dth} *(1.3 \mathrm{e}-06 *(6.4 \mathrm{e}-03 * \mathrm{dth} * 0.72+0.5))) *(\mathrm{dt} /(4.2 \mathrm{e}-3 * \mathrm{fmcp}))$

$130 \mathrm{dth}=\mathrm{ddth}+\mathrm{dth}$

th $=\mathrm{dth}+\operatorname{tar}$

$\mathrm{tc}=(\mathrm{th}-32) * .5 . / 9$.

write $(6, *)$ td,tc

C $\quad$ write $\left(6,{ }^{*}\right)$ td,y,q,mcp,cpal,cpfu

C write $\left(6,{ }^{*}\right)$ td,th

if(td.lt.tmax)goto 80

close(6)

end 